\title{
Os parasitas de ovinos
}

\author{
Alessandro Francisco Talamini do Amarante
}

\author{
Alessandra M. A. Ragozo \\ Bruna Fernanda da Silva \\ (collab.)
}

AMARANTE, AFT. Os parasitas de ovinos [online]. São Paulo: Editora UNESP, 2014, 263 p. ISBN 978-85-68334-42-3. Available from SciELO Books $<$ http://books.scielo.org $>$.

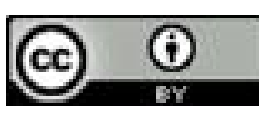

All the contents of this work, except where otherwise noted, is licensed under a Creative Commons Attribution 4.0 International license.

Todo o conteúdo deste trabalho, exceto quando houver ressalva, é publicado sob a licença Creative Commons Atribição $\underline{4.0}$.

Todo el contenido de esta obra, excepto donde se indique lo contrario, está bajo licencia de la licencia Creative Commons $\underline{\text { Reconocimento } 4.0 .}$. 


\section{Os PARASITAS DE OVINOS}




\title{
FUNDAÇÃO EDITORA DA UNESP
}

\author{
Presidente do Conselho Curador \\ Mário Sérgio Vasconcelos \\ Diretor-Presidente \\ José Castilho Marques Neto \\ Editor-Executivo \\ Jézio Hernani Bomfim Gutierre
}

Superintendente Administrativo e Financeiro

William de Souza Agostinho

Assessores Editoriais

João Luís Ceccantini

Maria Candida Soares Del Masso

Conselho Editorial Acadêmico

Áureo Busetto

Carlos Magno Castelo Branco Fortaleza

Elisabete Maniglia

Henrique Nunes de Oliveira

João Francisco Galera Monico

José Leonardo do Nascimento

Lourenço Chacon Jurado Filho

Maria de Lourdes Ortiz Gandini Baldan

Paula da Cruz Landim

Rogério Rosenfeld

Editores-Assistentes

Anderson Nobara

Jorge Pereira Filho

Leandro Rodrigues 


\title{
ALESSANDRO FRANCISCO TALAMINI DO AMARANTE
}

\section{OS PARASITAS DE OVINOS}

\author{
Colaboradores \\ Alessandra M. A. Ragozo \\ Bruna Fernanda da Silva
}


Direitos de publicação reservados à:

Fundação Editora da Unesp (FEU)

\author{
Praça da Sé, 108 \\ 01001-900 - São Paulo - SP \\ Tel.: (0xx11) 3242-7171 \\ Fax: (0xx11) 3242-7172 \\ www.editoraunesp.com.br \\ www.livrariaunesp.com.br \\ feu@editora.unesp.br
}

CIP - BRASIL. Catalogação na publicação

Sindicato Nacional dos Editores de Livros, RJ

\title{
A52p
}

Amarante, Alessandro Francisco Talamini do

Os parasitas de ovinos / Alessandro Francisco Talamini do Amarante; Bruna Fernanda da Silva; Alessandra M. A. Ragozo. São Paulo: Editora Unesp Digital, 2014.

Recurso digital

Formato: epdf

Requisitos do sistema: Adobe Acrobat Reader

Modo de acesso: World Wide Web

ISBN 978-85-68334-42-3 (recurso eletrônico)

1. Parasitologia médica. 2. Micologia médica. 3. Livros eletrônicos. I. Silva, Bruna Fernanda da. II. Ragozo, Alessandra M. A. III. Título.

$15-20463$

CDD: 616.96

CDU: 616.995 .1

Este livro é publicado pelo projeto Edição de Textos de Docentes e Pós-Graduados da UNESP - Pró-Reitoria de Pós-Graduação da UNESP (PROPG) / Fundação Editora da Unesp (FEU)

Editora afiliada:

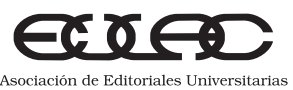

Asociación de Editoriales Universitarias de América Latina y el Caribe

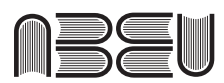

Associação Brasileira de Editoras Universitárias 


\section{SUMÁRIO}

\section{Apresentação 7}

\section{HELMINTOS}

Introdução 11

1 Classe nematoda 13

2 Classe trematoda 99

3 Classe cestoda 111

4 Anti-helmínticos 123

\section{PROTOZOÁRIOS}

5 Eimeriose 139

6 Cryptosporidiose 147

7 Tripanosomíase 149

8 Toxoplasmose, neosporose e sarcocistose 153

\section{ARTRÓPODES}

9 Miíases 207

10 Piolhos e ácaros 253 


\section{ApresentaÇÃo}

Este livro apresenta informações sobre as principais parasitoses que acometem ovinos criados no Brasil e tem por objetivo fornecer subsídios para a elaboração de estratégias de profilaxia das enfermidades parasitárias. Trabalhos relevantes realizados por pesquisadores brasileiros, bem como de outros países, foram imprescindíveis como fonte de consulta para a elaboração dos textos. Aqui também estão apresentados os resultados obtidos no Laboratório de Helmintologia Veterinária, especialmente a partir de 1988, quando o autor deste livro iniciou suas atividades na Unesp, campus de Botucatu. Desde aquela data, várias dissertações e teses foram elaboradas por estudantes de pós-graduação, cujos resultados estão a seguir apresentados.

A maioria das fotografias apresentadas no livro foi obtida pelo próprio autor, com a colaboração de alunos e técnicos do Departamento de Parasitologia; porém, merece destaque o inestimável auxílio prestado pelo pós-graduando César Cristiano Bassetto na colheita de material e montagem de lâminas. 
HELMINTOS 


\section{INTRODUÇÃO}

Os helmintos são classificados em dois grandes grupos, denominados filos: Nemathelminthes e Platyhelminthes. O primeiro grupo é constituído por vermes que apresentam o corpo cilíndrico, enquanto que no segundo grupo os vermes apresentam o corpo achatado dorso-ventralmente. Os principais gêneros de helmintos com as suas respectivas classificações estão apresentados na Tabela 1. Três classes de parasitas se destacam: Nematoda, Cestoda e Trematoda, as quais serão abordadas separadamente.

Tabela 1 - Classificação dos principais helmintos que parasitam ovinos

\begin{tabular}{|c|c|c|c|c|}
\hline Filo & Classe & Ordem & Família & Gênero \\
\hline \multirow{11}{*}{$\begin{array}{l}\text { Nemathelminthes } \\
\text { (Aschelminthes) }\end{array}$} & \multirow[t]{11}{*}{ Nematoda $^{1}$} & \multirow[t]{8}{*}{ Strongylida } & \multirow[t]{4}{*}{ Trichostrongylidae } & Haemonchus \\
\hline & & & & Ostertagia \\
\hline & & & & Trichostrongylus \\
\hline & & & & Cooperia \\
\hline & & & Molineidae & Nematodirus \\
\hline & & & Ancylostomatidae & Bunostomum \\
\hline & & & Chabertiidae & Oesophagostomum \\
\hline & & & Dictyocaulidae & Dictyocaulus \\
\hline & & Rhaditida & Strongyloididae & Strongyloides \\
\hline & & Enoplida & Trichuridae & Trichuris \\
\hline & & Oxyurida & Oxyuridae & Skrjabinema \\
\hline \multirow[t]{3}{*}{ Platyhelminthes } & Cestoda $^{2}$ & Cyclophyllidea & Anoplocephalidae & Moniezia \\
\hline & \multirow[t]{2}{*}{ Trematoda } & & Fasciolidae $^{3}$ & Fasciola \\
\hline & & & Dicrocoeliidae $^{4}$ & Eurytrema \\
\hline
\end{tabular}

Classificação de acordo com (1) Anderson et al., 2009; (2) Schmidt, 1986; (3) Jones et al., 2005; e (4) Bray et al., 2008 


\section{1 \\ Classe nematoda}

A verminose causada por nematódeos gastrintestinais constitui o principal problema sanitário dos rebanhos ovinos. O controle adequado dessa enfermidade é imperativo, caso contrário, a atividade pode se tornar inviável economicamente devido à redução na produtividade e à mortalidade de animais.

\section{Principais espécies de nematódeos em ovinos}

Os ovinos podem ser parasitados simultaneamente por várias espécies de nematódeos. Algumas das inúmeras espécies que já foram registradas em ovinos no Brasil estão listadas na Tabela 2. A diversidade de espécies que parasitam os animais é influenciada pela frequência de tratamentos com anti-helmíntico, pelo manejo e pelas condições ambientais. No Sul do Brasil, por exemplo, as temperaturas baixas do inverno favorecem a ocorrência de Ostertagia (Teladorsagia) circumcincta, espécie que não tem sido registrada em ovinos criados em outras regiões do país (Tabela 2). Além dessa espécie, ainda é comum a ocorrência de Nematodirus spp. e Oesophagostomum venulosum (Santiago et al., 1975; Ramos et al., 2004). Porém, no Rio Grande do Sul, a exemplo dos demais estados brasileiros, $H$. contortus é a espécie predominante, especialmente 
nos meses de verão, enquanto que Trichostrongylus spp. e O. circumcincta predominam nos períodos com baixas temperaturas, nos meses de inverno e primavera, quando causam problemas clínicos e redução na produtividade dos ovinos (Echevarria et al., 1996).

A diversidade de espécies de nematódeos é maior quando os ovinos compartilham pastagens com bovinos (Giudici et al., 1999). Por outro lado, quando os animais são tratados frequentemente com anti-helmíntico, algumas espécies desses parasitas desaparecem, e apenas aquelas com maior potencial biótico permanecem parasitando o rebanho. Os parasitas pulmonares de ovinos são exemplo de nematódeos que deixam de ser registrados após a aplicação rotineira de anti-helmínticos de amplo espectro (Ramos et al., 2004).

A importância relativa das diferentes espécies varia em função da interação entre vários fatores, em especial, intensidade da infecção, prevalência e patogenicidade do parasita. Com base nesses três fatores, pode-se afirmar que Haemonchus contortus é a principal espécie que parasita ovinos no Brasil (Arosemena et al., 1999; Amarante et al., 2004; Ramos et al., 2004). Além disso, as populações desse nematódeo com frequência apresentam resistência aos anti-helmínticos.

Tabela 2 - Prevalência (\%) de nematódeos gastrintestinais e intensidade média da infecção (entre parênteses) em ovinos criados em oito estados brasileiros

\begin{tabular}{|c|c|c|c|c|c|c|c|c|}
\hline \multirow[t]{2}{*}{ Espécie } & \multicolumn{8}{|c|}{ Estado } \\
\hline & $\mathrm{RS}^{1}$ & $\mathrm{SC}^{2}$ & $\mathrm{SP}^{3}$ & $\mathbf{M G}^{4}$ & $\mathrm{CE}^{5}$ & $\mathrm{BA}^{6}$ & $\mathrm{RN}^{7}$ & $\mathbf{M S}^{8}$ \\
\hline $\begin{array}{l}\text { Haemonchus } \\
\text { contortus }\end{array}$ & $\begin{array}{l}88 \% \\
(88) \\
\end{array}$ & $100 \%$ & \begin{tabular}{|l|}
$100 \%$ \\
$(3265)$ \\
\end{tabular} & $\begin{array}{l}85,3 \% \\
(1487) \\
\end{array}$ & $\begin{array}{r}71 \% \\
(491)\end{array}$ & $\begin{array}{l}60 \% \\
(162) \\
\end{array}$ & $82,3 \%$ & $73,4 \%$ \\
\hline $\begin{array}{l}\text { Trichostrongylus } \\
\text { axei }\end{array}$ & $\begin{array}{l}54 \% \\
(67) \\
\end{array}$ & $98,7 \%$ & $\begin{array}{l}8 \% \\
(2) \\
\end{array}$ & $\begin{array}{c}77,3 \% \\
(367)\end{array}$ & $\begin{array}{l}27,1 \% \\
(207) \\
\end{array}$ & $\begin{array}{c}27 \% \\
(183) \\
\end{array}$ & - & - \\
\hline $\begin{array}{l}\text { Ostertagia } \\
\text { circumcincta }\end{array}$ & $\begin{array}{c}92 \% \\
(130)\end{array}$ & $100 \%$ & - & - & - & - & - & - \\
\hline $\begin{array}{l}\text { Ostertagia } \\
\text { ostertagi }\end{array}$ & $\begin{array}{l}70 \% \\
(31) \\
\end{array}$ & $100 \%$ & - & - & - & - & - & - \\
\hline $\begin{array}{l}\text { Ostertagia } \\
\text { trifurcata }\end{array}$ & $\begin{array}{l}54 \% \\
(22) \\
\end{array}$ & - & - & - & - & - & - & - \\
\hline Ostertagia lyrata & $\begin{array}{c}30 \% \\
(8) \\
\end{array}$ & - & - & - & - & - & - & - \\
\hline $\begin{array}{l}\text { Trichostrongylus } \\
\text { colubriformis }\end{array}$ & $\begin{array}{r}58 \% \\
(101) \\
\end{array}$ & $100 \%$ & $\begin{array}{c}85 \% \\
(2154) \\
\end{array}$ & $\begin{array}{l}94,7 \% \\
(4872) \\
\end{array}$ & $\begin{array}{l}1 \% \\
(8)\end{array}$ & $\begin{array}{r}40 \% \\
(652) \\
\end{array}$ & $21,0 \%$ & $9,9 \%$ \\
\hline
\end{tabular}


Tabela 2 - Continuação

\begin{tabular}{|c|c|c|c|c|c|c|c|c|}
\hline Cooperia curticei & $\begin{array}{c}4 \% \\
(0,6) \\
\end{array}$ & $6,9 \%$ & $\begin{array}{c}73 \% \\
(169) \\
\end{array}$ & - & - & $\begin{array}{c}20 \% \\
(465) \\
\end{array}$ & - & $7,2 \%$ \\
\hline $\begin{array}{l}\text { Cooperia } \\
\text { oncophora }\end{array}$ & $\begin{array}{l}44 \% \\
(29)\end{array}$ & $4,8 \%$ & - & - & - & - & - & - \\
\hline Cooperia punctata & $\begin{array}{l}42 \% \\
(16)\end{array}$ & $69,1 \%$ & $\begin{array}{l}50 \% \\
(34) \\
\end{array}$ & $\begin{array}{r}96 \% \\
(964) \\
\end{array}$ & - & $\begin{array}{c}2 \% \\
(20) \\
\end{array}$ & $11,3 \%$ & $5 \%$ \\
\hline $\begin{array}{l}\text { Cooperia } \\
\text { pectinata }\end{array}$ & - & $18,4 \%$ & $\begin{array}{l}12 \% \\
(13)\end{array}$ & - & - & - & $6,5 \%$ & $4,4 \%$ \\
\hline $\begin{array}{l}\text { Cooperia } \\
\text { mcmasteri }\end{array}$ & $\begin{array}{c}10 \% \\
(2)\end{array}$ & - & - & - & - & - & - & - \\
\hline Cooperia spatulata & - & $0,8 \%$ & - & - & - & - & - & - \\
\hline $\begin{array}{l}\text { Bunostomum } \\
\text { trigonocephalum }\end{array}$ & - & - & $\begin{array}{c}3,8 \% \\
(1)\end{array}$ & $\begin{array}{l}68 \% \\
(18) \\
\end{array}$ & $\begin{array}{c}0,02 \% \\
(0,2)\end{array}$ & $\begin{array}{c}6 \% \\
(33) \\
\end{array}$ & - & - \\
\hline $\begin{array}{l}\text { Nematodirus } \\
\text { spatigher }\end{array}$ & $\begin{array}{c}78 \% \\
(130)\end{array}$ & $100 \%$ & - & - & - & - & - & - \\
\hline $\begin{array}{l}\text { Strongyloides } \\
\text { papillosus }\end{array}$ & $\begin{array}{l}16 \% \\
(13)\end{array}$ & - & $\begin{array}{l}19 \% \\
(22) \\
\end{array}$ & $\begin{array}{c}13,3 \% \\
(3) \\
\end{array}$ & $\begin{array}{c}0,02 \% \\
(0,2)\end{array}$ & $\begin{array}{r}40 \% \\
(652) \\
\end{array}$ & - & - \\
\hline $\begin{array}{l}\text { Oesophagostomum } \\
\text { columbianum }\end{array}$ & $\begin{array}{c}18 \% \\
(1)\end{array}$ & - & $\begin{array}{c}69 \% \\
(125) \\
\end{array}$ & $\begin{array}{c}78,7 \% \\
(52) \\
\end{array}$ & $\begin{array}{c}0,6 \% \\
(5)\end{array}$ & $\begin{array}{l}46 \% \\
(18) \\
\end{array}$ & $8,1 \%$ * & $0,2 \%$ \\
\hline $\begin{array}{l}\text { Oesophagostomum } \\
\text { venulosum }\end{array}$ & $\begin{array}{c}72 \% \\
(9)\end{array}$ & $100 \%$ & - & - & - & $\begin{array}{c}2 \% \\
(55)\end{array}$ & - & - \\
\hline Trichuris ovis & $\begin{array}{c}88 \% \\
(5)\end{array}$ & $100 \%$ & $\begin{array}{c}3,8 \% \\
(1)\end{array}$ & - & - & $\begin{array}{l}3 \% \\
(6) \\
\end{array}$ & $27,4 \% *$ & - \\
\hline $\begin{array}{l}\text { Trichuris } \\
\text { globulosa }\end{array}$ & $\begin{array}{c}60 \% \\
(3)\end{array}$ & - & - & - & - & $\begin{array}{c}47 \% \\
(5)\end{array}$ & - & - \\
\hline Trichuris discolor & - & - & - & $\begin{array}{c}4 \% \\
(0,5) \\
\end{array}$ & - & - & - & - \\
\hline Skrjabinema ovis & - & - & - & - & - & $\begin{array}{l}25 \% \\
(27)\end{array}$ & $1,6 \%$ & - \\
\hline
\end{tabular}

Fonte: (1) Vieira et al., 1989; (2) Ramos et al., 2004; (3) Vasconcelos et al., 1985; (4) Guimarães et al., 1976; (5) Arosemena et al., 1999; (6) Lopes et al., 1975; (7) Souza et al., 2012; (8) Sczesny-Moraes et al., 2010.

*Não foi possível a identificação da espécie.

\section{Haemonchus contortus}

Principal espécie que parasita ovinos em regiões com clima tropical e subtropical. H. contortus é um parasita hematófago que tem por habitat o abomaso dos ruminantes. Os vermes adultos apresentam de $1 \mathrm{~cm}$ a $3 \mathrm{~cm}$ de comprimento e são facilmente observados a olho nu (Figura 1). Os espículos do macho apresentam ganchos com comprimentos desiguais nas extremidades (Figura 2). 
Figura 1 - Abomaso de cordeiro com infecção pesada por Haemonchus contortus

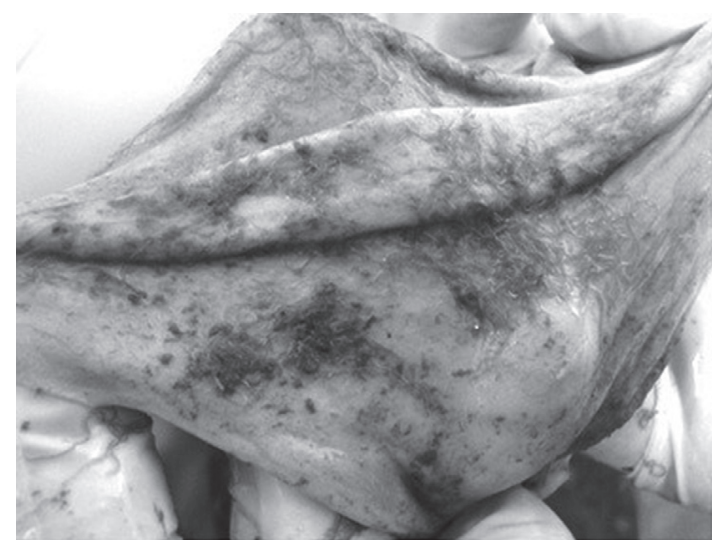

Figura 2 - (a) Bolsa copuladora de exemplar macho de Haemonchus contortus com dois espículos e gubernáculo; (b) ganchos nas extremidades dos espículos
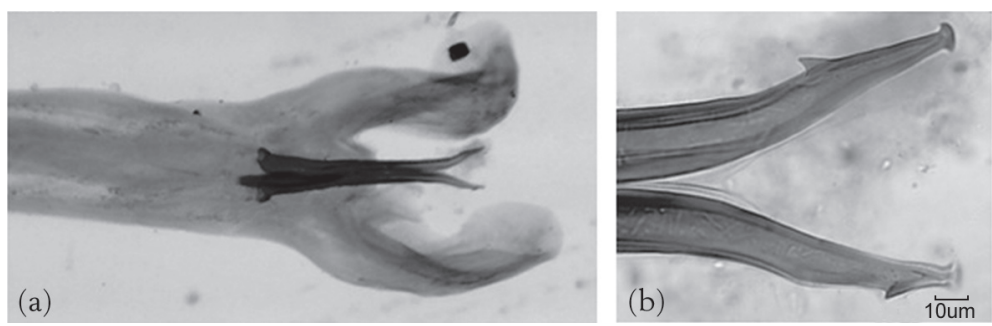

\section{Trichostrongylus spp.}

Duas espécies do gênero Trichostrongylus parasitam ovinos. A mais importante delas é Trichostrongylus colubriformis, parasita do intestino delgado que, além de muito comum, também com frequência apresenta resistência aos anti-helmínticos (Amarante et al., 2004; Almeida et al., 2010). A outra espécie, Trichostrongylus axei, parasita o abomaso. Não é comum em ovinos criados no estado de São Paulo, porém tem sido registrada com frequência em ovinos de outros estados, usualmente com baixa intensidade de infecção (Santiago et al., 1976; Ramos et al., 2004). Os vermes adultos são 
pequenos, apresentam de $4 \mathrm{~mm}$ a $12 \mathrm{~mm}$ de comprimento, e vivem em túneis nas vilosidades (Figura 3). Não é possível visualizá-los a olho nu em meio ao conteúdo gastrintestinal. A identificação precisa das espécies requer a montagem dos exemplares entre em lâminas (figura 4 a 7 ).

Figura 3 - Corte histológico do intestino delgado de cordeiro parasitado por Trichostrongylus colubriformis. Setas indicam os parasitas no interior da mucosa
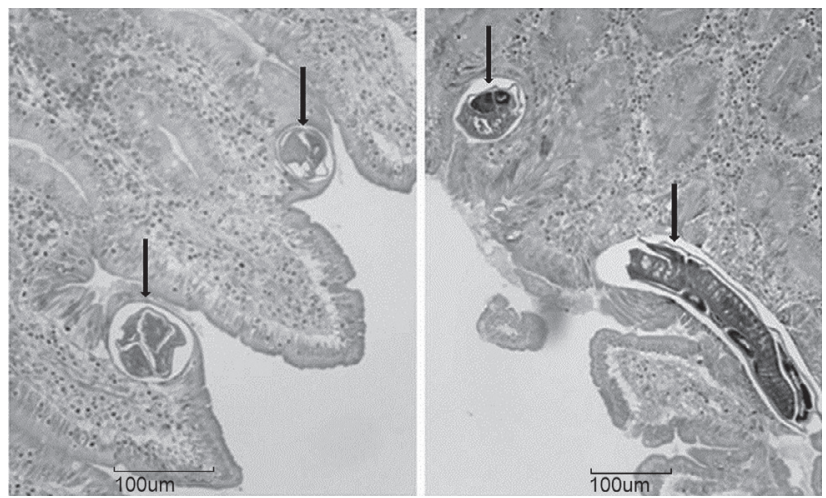

Figura 4 - Extremidade anterior de Trichostrongylus colubriformis
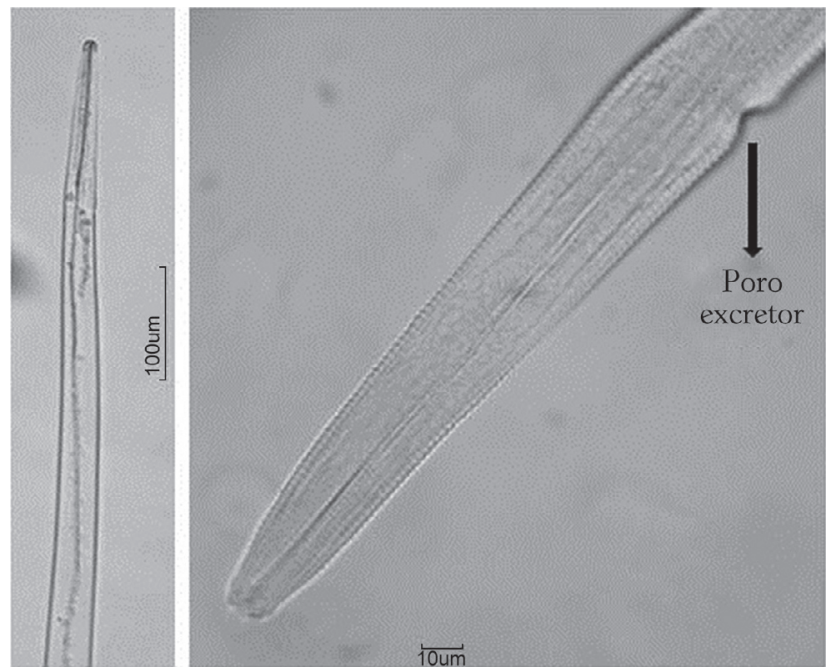
Figura 5 - Extremidade posterior de fêmea de Trichostrongylus colubriformis
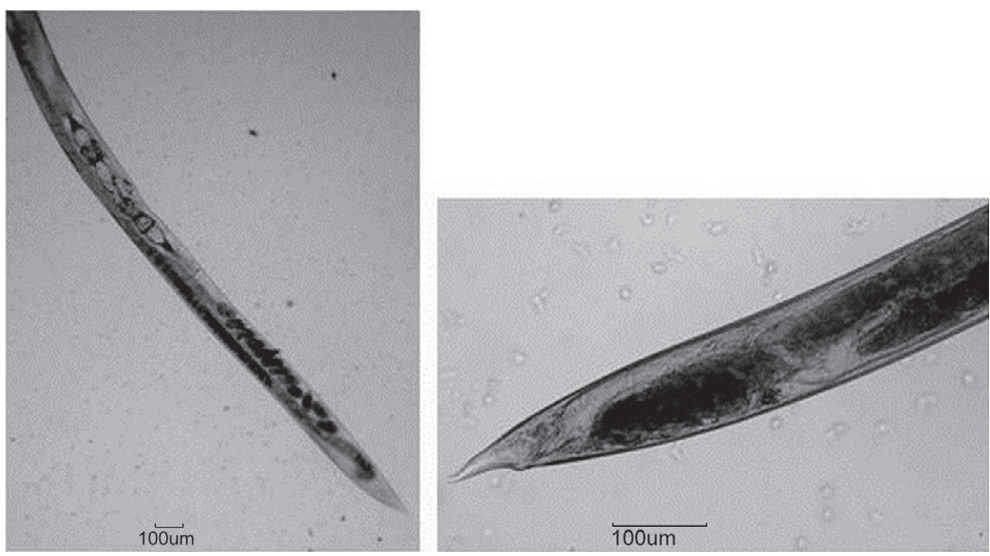

Figura 6 - Extremidade posterior de macho de Trichostrongylus colubriformis. Extremidade dos espículos com formato de arpão

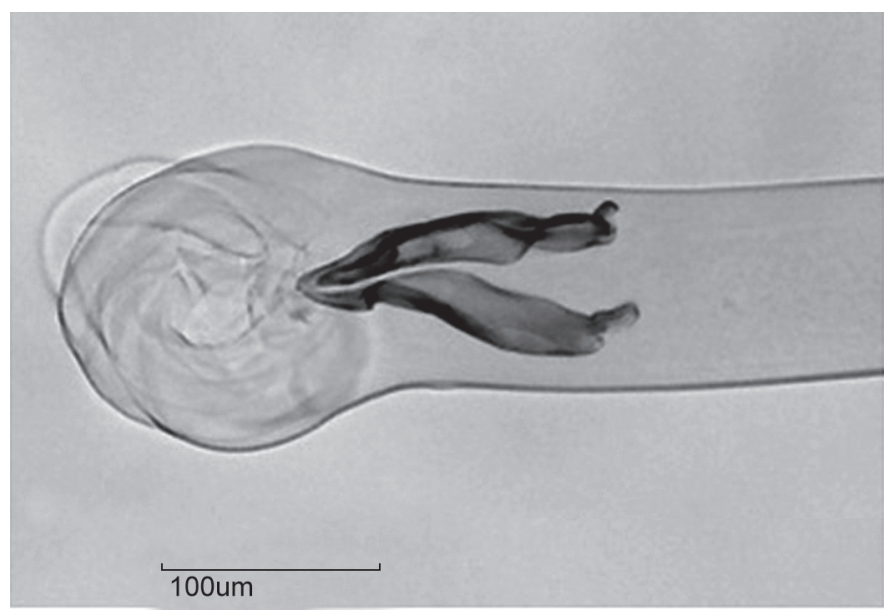


Figura 7 - Extremidade posterior de macho de Trichostrongylus axei com espículos desiguais e gubernáculo

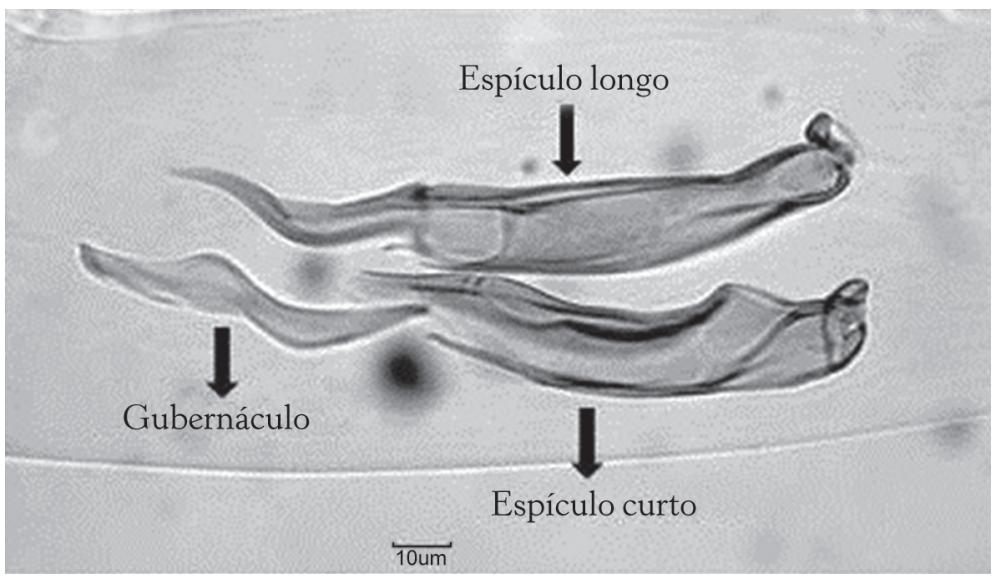

\section{Cooperia spp.}

Geralmente as infecções dos ovinos por Cooperia spp. são leves. Quando ovinos são criados isolados de outras espécies de ruminantes, usualmente, apenas a espécie Cooperia curticei é detectada (Amarante et al., 2004; 2009). Porém, outras espécies frequentes em bovinos, tais como Cooperia punctata, Cooperia pectinata e Cooperia spatulata, podem ser encontradas em ovinos, especialmente quando estes animais compartilham pastagens com bovinos (idem, 1997; Rocha et al., 2008). No Sul do Brasil, a espécie Cooperia oncophora, parasita de bovinos, também pode ser encontrada infectando ovinos (Vieira et al., 1989). Os vermes adultos são pequenos, apresentam de $10 \mathrm{~mm}$ a $20 \mathrm{~mm}$ de comprimento (figuras 8 a 11), e não é possível visualizá-los a olho nu em meio ao conteúdo intestinal. 
Figura 8 - Extremidade anterior e extremidade posterior de fêmea de Cooperia spp.

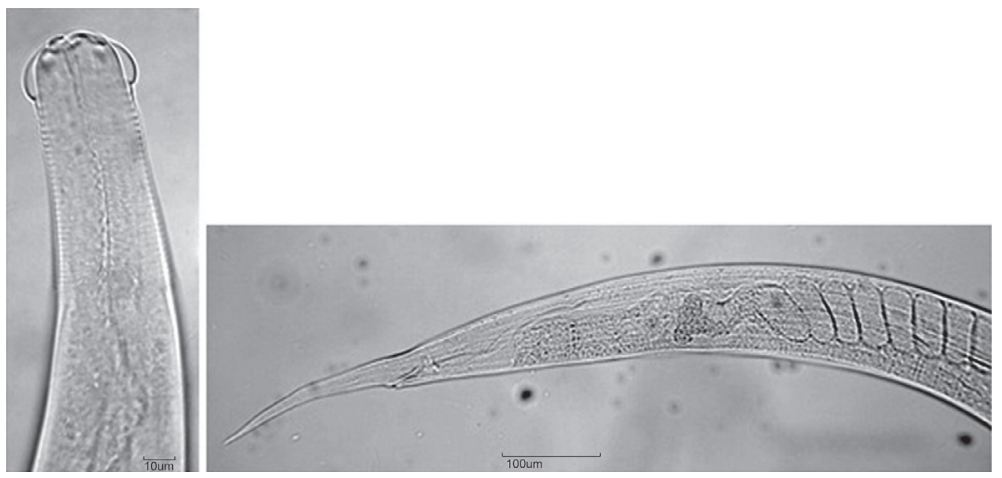

Figura 9 - Bolsa copuladora e espículos de macho de Cooperia punctata

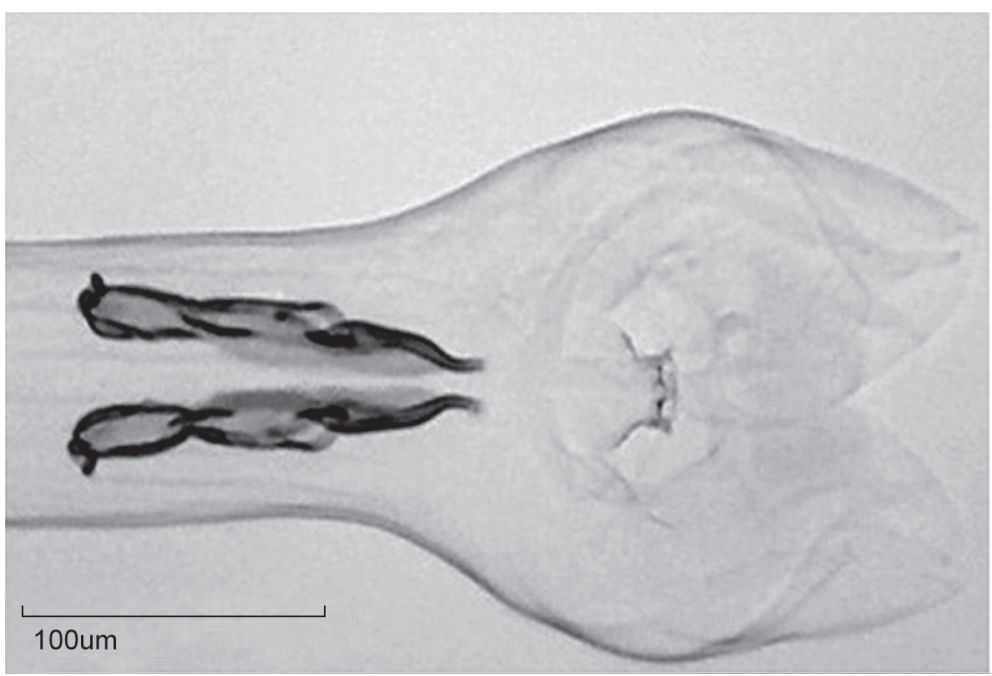


Figura 10 - Espículos de macho de Cooperia curticei

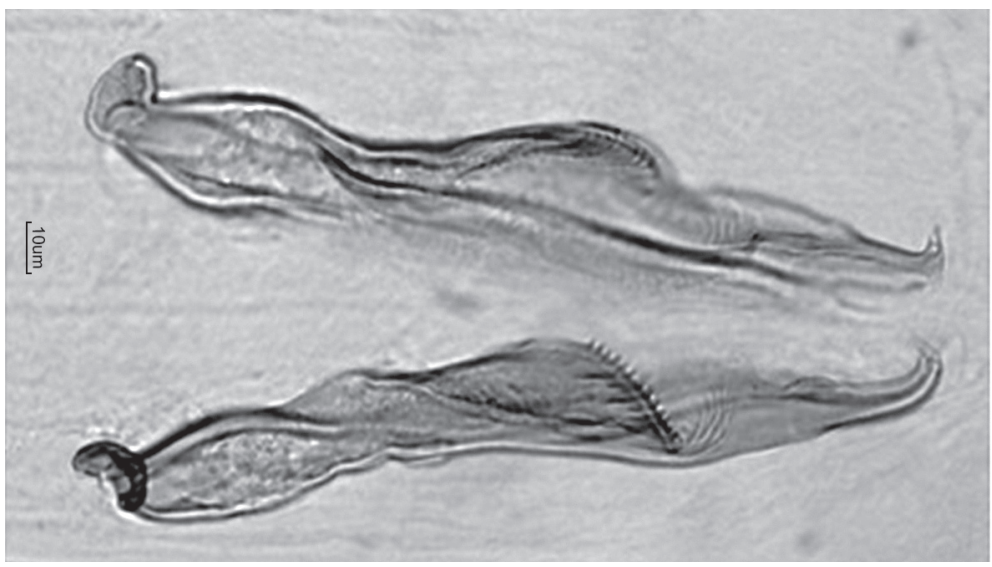

Figura 11 - Espículos de macho de Cooperia spatulata

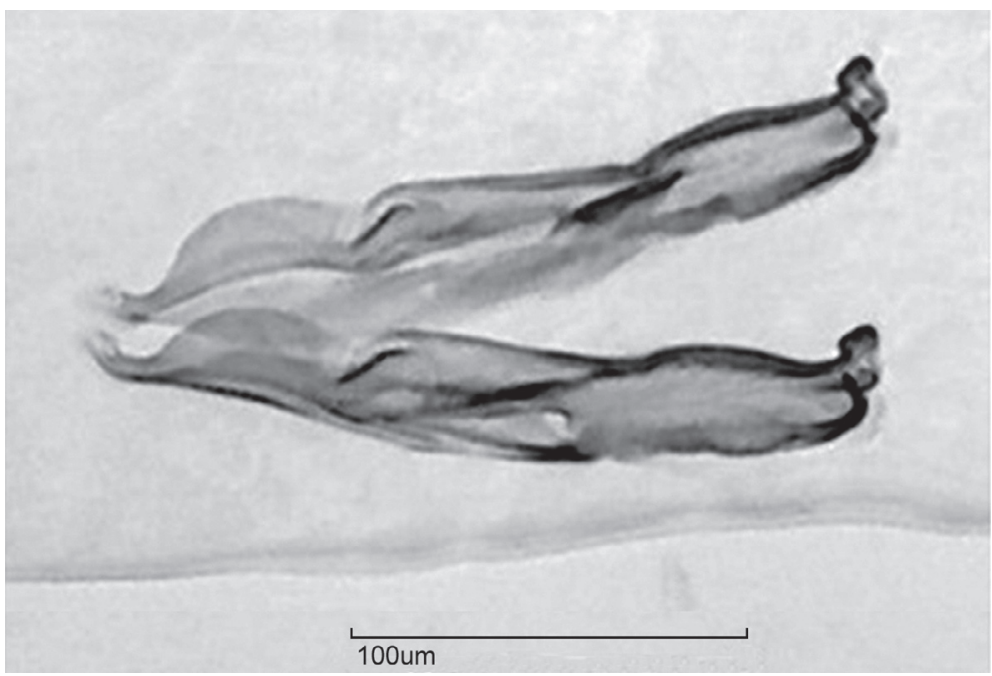




\section{Strongyloides papillosus}

Apenas fêmeas partenogenéticas da espécie S. papillosus ocorrem no intestino delgado dos ovinos (Figura 12). Dos helmintos gastrintestinais, são os menores. As fêmeas apresentam de $3 \mathrm{~mm}$ a $6 \mathrm{~mm}$ de comprimento. Não é possível visualizá-las a olho nu em meio ao conteúdo intestinal.

Figura 12 - Extremidade anterior (a) e posterior (b) de fêmea partenogenética de Strongyloides papillosus
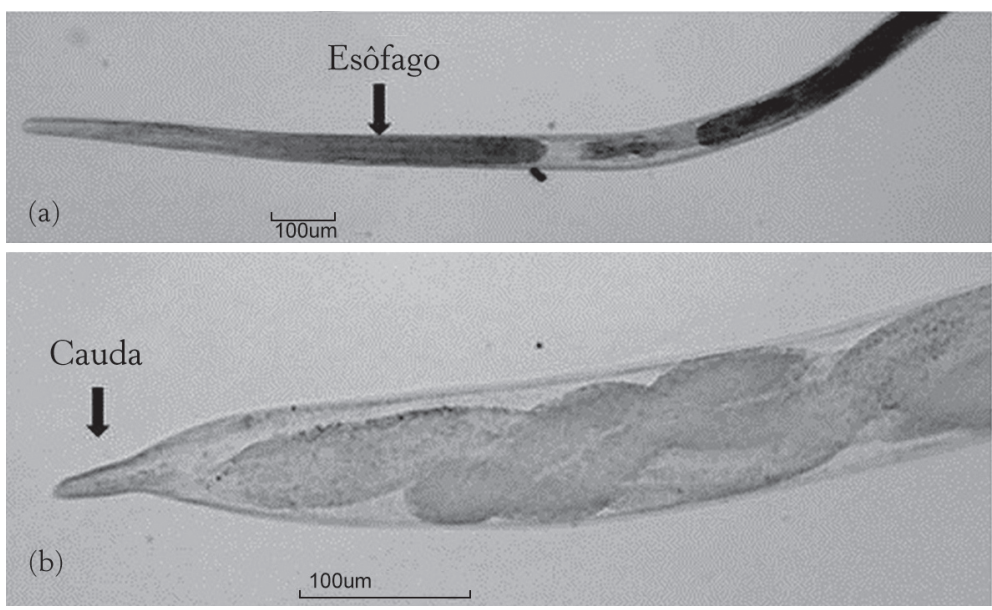

\section{Oesophagostomum spp.}

Oesophagostomum columbianum é outra espécie merecedora de destaque devido a sua elevada patogenicidade, além do que, está presente com relativa frequência nos rebanhos ovinos (Lopes et al., 1975; Santiago et al., 1976; Amarante et al., 2004). Animais infectados por Oesophagostomum spp. apresentam lesões nodulares típicas na parede intestinal. Os parasitas adultos (figuras 13 e 14), encontrados no intestino grosso, são relativamente grandes, apresentam de $12 \mathrm{~mm}$ a $21 \mathrm{~mm}$ de comprimento, e podem ser visualizados a olho nu. 
Figura 13 - Extremidade anterior de Oesophagostomum columbianum

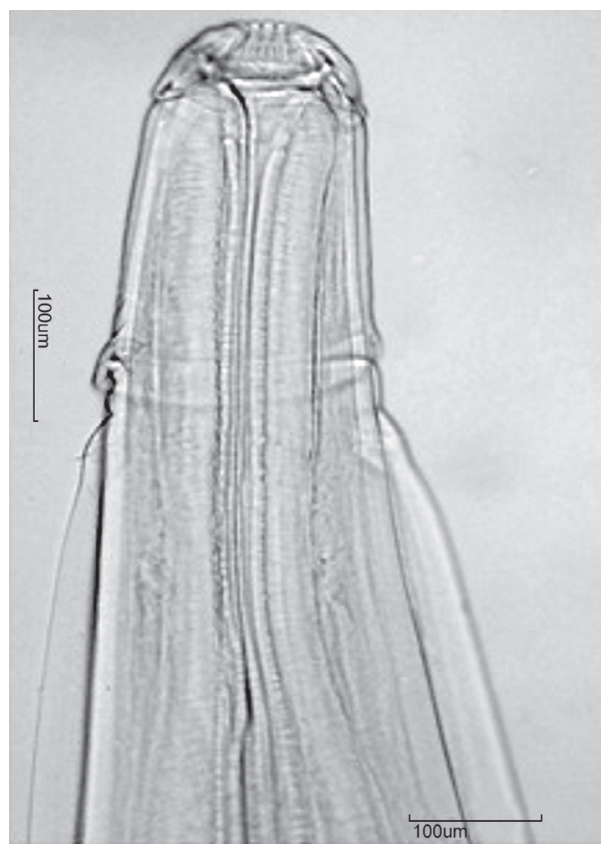

Figura 14 - Extremidade posterior de Oesophagostomum columbianum. Bolsa copuladora e dois espículos

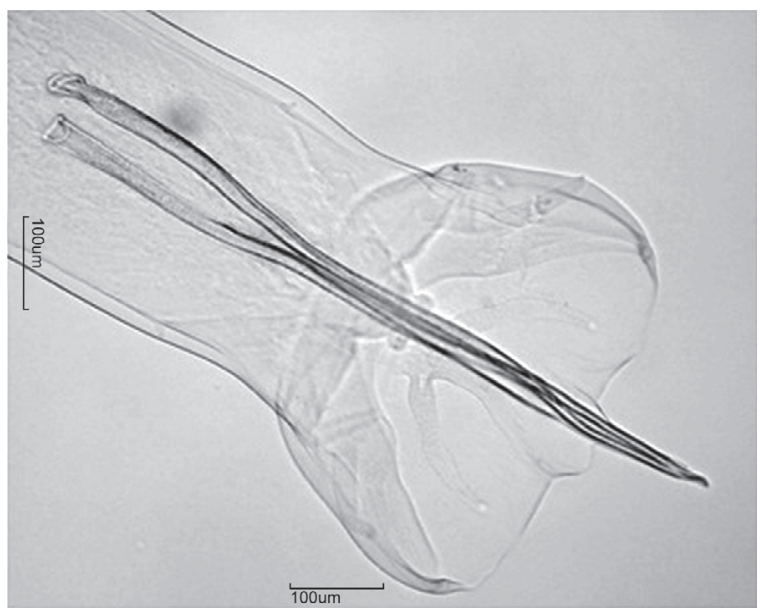




\section{Trichuris spp.}

Os parasitas do gênero Trichuris apresentam extremidade anterior afilada, a qual permanece inserida no interior da mucosa do intestino grosso (Figura 15). Três espécies de Trichuris foram registradas em ovinos no Brasil: Trichuris ovis (Figura 16), Trichuris globulosa e Trichuris discolor (Figura 17). Os parasitas adultos são relativamente grandes, apresentam de $35 \mathrm{~mm}$ a $85 \mathrm{~mm}$ de comprimento, e podem ser visualizados facilmente a olho nu, fixados à parede intestinal.

Figura 15 - Vários parasitas do gênero Trichuris aderidos no intestino grosso de ovino

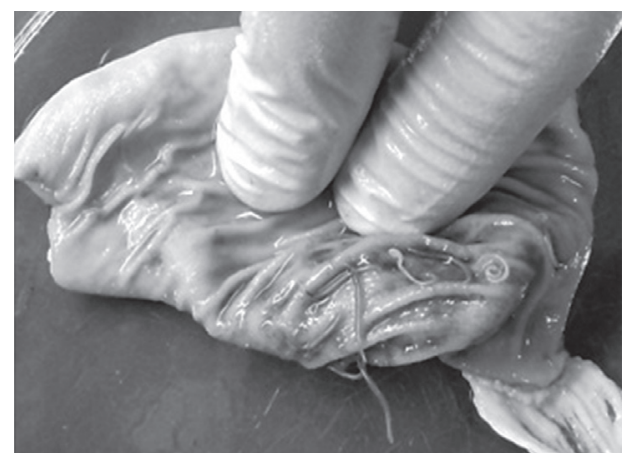

Figura 16 - Extremidade distal de macho de Trichuris ovis. Bainha do espículo com dilatação na extremidade

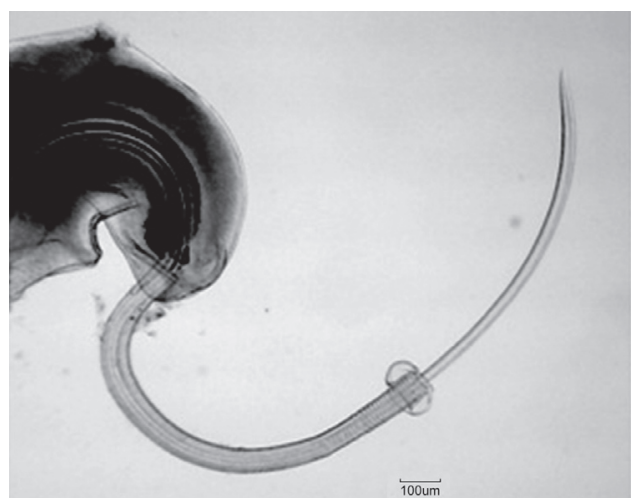


Figura 17 - Bainha do espículo de Trichuris discolor
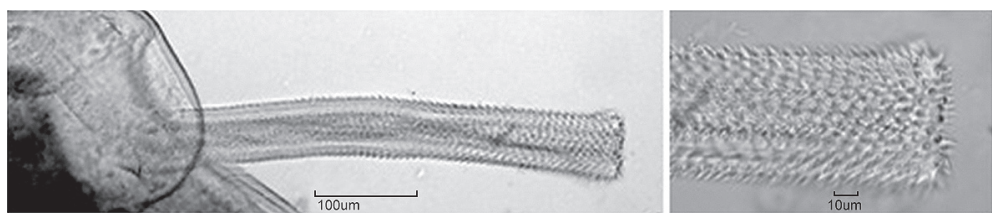

\section{Ciclo evolutivo}

Apesar de cada espécie apresentar peculiaridades em relação ao seu ciclo evolutivo, de forma geral, ele ocorre do seguinte modo: os parasitas adultos vivem no trato digestório dos animais, onde realizam a postura de grande quantidade de ovos, que são eliminados para o ambiente com as fezes. Desses ovos eclodem larvas de primeiro estágio (L1), que, após um período de desenvolvimento, mudam de cutícula e dão origem a larvas de segundo estágio (L2), as quais, por sua vez, dão origem às larvas infectantes de terceiro estágio (L3), isto é, aptas a parasitar um novo hospedeiro. Os ovinos, ao pastejar, ingerirão a vegetação contaminada pelas larvas infectantes, que retomam o desenvolvimento no aparelho digestivo do ruminante, sofrem mudas e dão origem a fêmeas e machos adultos, os quais darão sequência ao ciclo evolutivo do parasita. No caso de algumas espécies de nematódeos, a larva infectante permanece no interior do ovo, e a eclosão só ocorre após a ingestão deste.

Portanto, existem duas fases distintas na vida do parasita, uma fase de vida livre e outra de vida parasitária.

\section{Fase de vida livre dos nematódeos da família Trichostrongylidae}

O desenvolvimento e a sobrevivência dos estágios de vida livre dos nematódeos no ambiente constituem elementos cruciais para a transmissão dos parasitas. Em relação à população dos estágios de vida livre, três aspectos são relevantes: (1) desenvolvimento dos ovos até larva infectante de terceiro estágio; (2) migração das larvas 
infectantes das fezes para a pastagem e (3) sobrevivência das larvas infectantes no ambiente.

\section{Desenvolvimento dos ovos até larvas infectantes de terceiro estágio}

Os ovos são eliminados nas fezes em estágio de mórula e se desenvolvem com o decorrer do tempo, com a formação de uma larva de primeiro estágio (L1) (Figura 18). A L1 eclode do ovo, se alimenta de matéria orgânica e microrganismos presentes nas próprias fezes e realiza uma mudança de cutícula, dando origem à larva de segundo estágio (L2), que continua se alimentando e se desenvolvendo até dar origem a uma larva infectante de terceiro estágio. Essa larva retém a cutícula do segundo estágio e, por essa razão, apresenta dupla cutícula: a nova que se formou e a externa, que a acompanha desde o segundo estágio (Figura 19). As larvas infectantes não se alimentam mais no ambiente, e sobrevivem com as reservas que acumularam nas células intestinais durante os estágios de L1 e L2.

No ambiente, o desenvolvimento dos estágios de vida livre ocorre nas próprias fezes, onde as larvas se alimentam de microrganismos e matéria orgânica. Durante esse processo, é indispensável que as fezes se mantenham úmidas, pois, em caso de dessecação, as L1 e L2 não sobrevivem. Solo úmido, chuvas frequentes e a sombra da vegetação favorecem a manutenção da umidade das fezes e, por consequência, o desenvolvimento das larvas. A dessecação pode ocorrer rapidamente, especialmente quando as fezes são expostas

Figura 18 - Desenvolvimento dos ovos de Haemonchus contortus no ambiente: (a) ovo em estágio inicial de desenvolvimento, logo após a eliminação nas fezes. Observar células no interior; (b) ovo larvado. Observar larva de primeiro estágio no interior do ovo
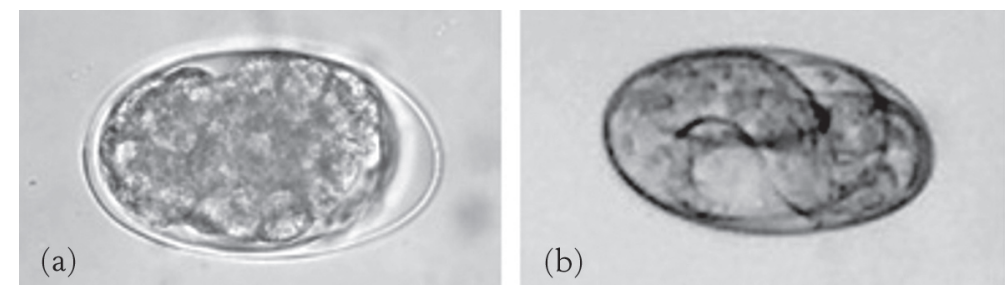
Figura 19 - Desenvolvimento de Haemonchus contortus no ambiente: (a) larvas de primeiro estágio (L1); (b) L1 corada com Lugol. Observar esôfago rabditoide; (c) larva de segundo estágio (L2) 72 horas após a incubação de fezes ovinas a $26^{\circ} \mathrm{C}$; (d) larva infectante de terceiro estágio (L3) com dupla cutícula. Obsevar células intestinais (coloração escura) e esôfago filarioide (coloração clara na extremidade anterior)
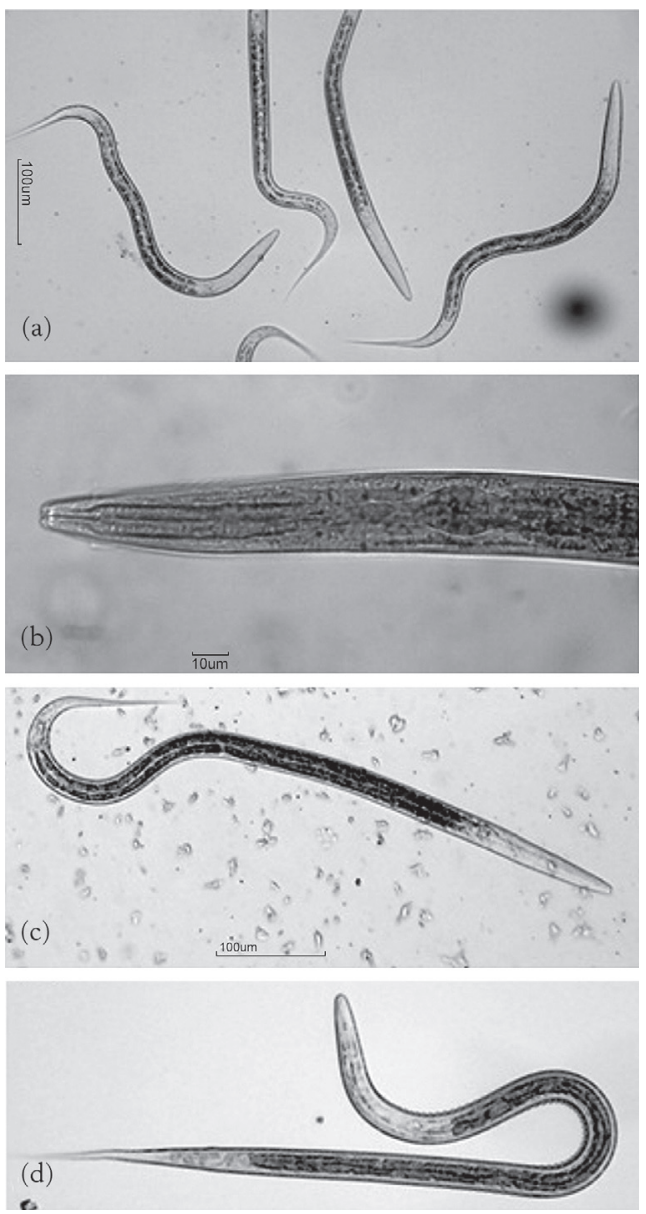

ao sol, o que causa elevada mortalidade dos estágios de vida livre, especialmente das L1 e L2, que são bastante vulneráveis.

O tempo necessário para o desenvolvimento varia em função da temperatura ambiental. As larvas se tornam infectantes em sete 
dias, ou menos, quando as fezes são mantidas em estufa em temperatura constante de $25^{\circ} \mathrm{C}$. Quanto mais baixa a temperatura, mais lento será o desenvolvimento. Em temperatura de $4{ }^{\circ} \mathrm{C}$, dentro do refrigerador, os ovos não se desenvolvem e, com o decorrer do tempo, começam a ser tornar inviáveis, especialmente aqueles de espécies adaptadas a altas temperaturas, como é o caso de H. contortus. As larvas infectantes apresentam peculiaridades morfológicas que permitem a identificação em gênero (figuras 20 a 23).

Figura 20 - Larva infectante de Trichostrongylus spp. (a) com cauda da bainha curta (b)
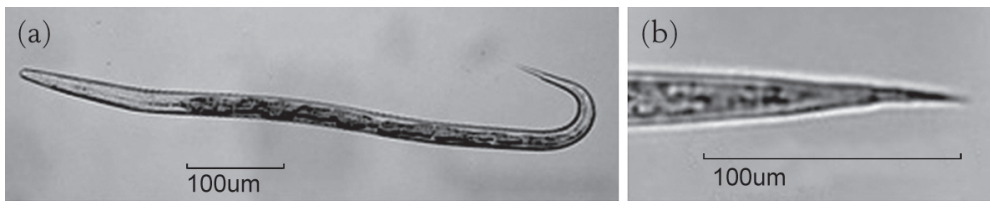

Figura 21 - Larva infectante de Cooperia spp. apresenta cauda da bainha de comprimento médio, com a presença de corpos refringentes na extremidade anterior

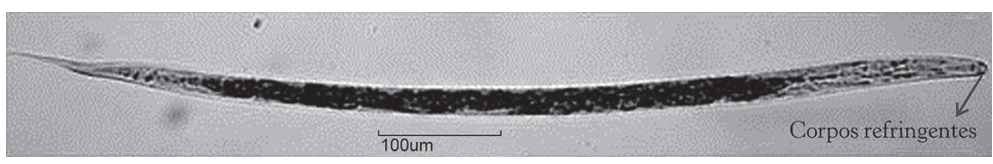

Figura 22 - Larva infectante de Trichostrongylus spp. com cauda da bainha curta e larva infectante de Haemonchus spp. com cauda da bainha de comprimento médio

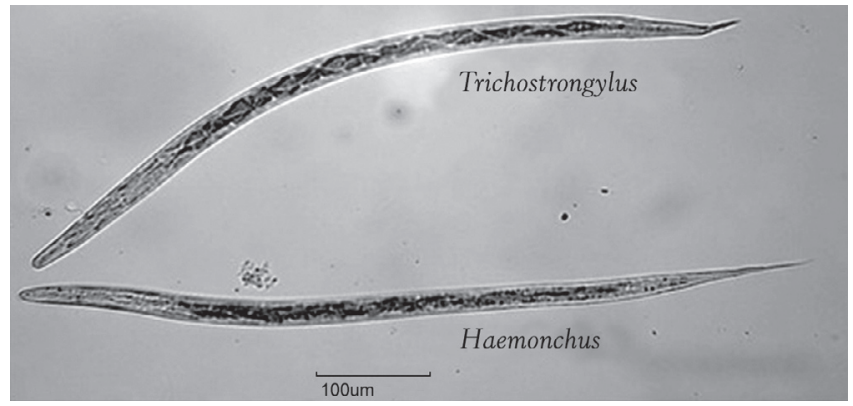


Figura 23 - Larva infectante de Oesophagostomum spp. com cauda da bainha de comprimento longo

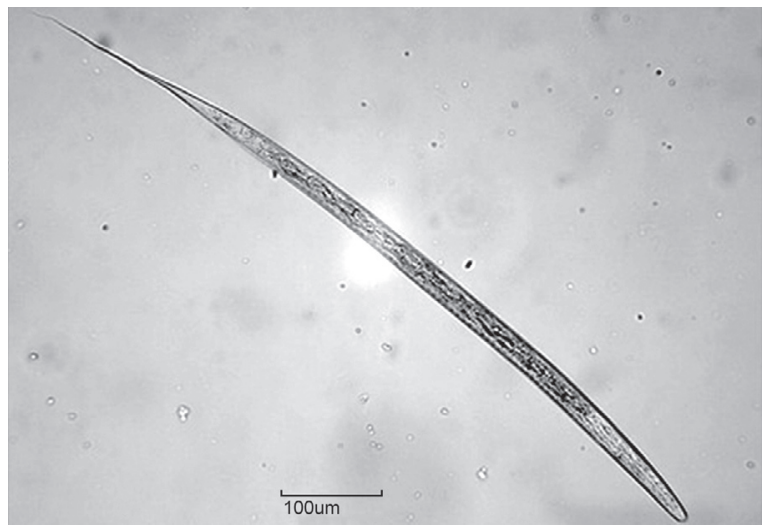

\section{Migração das larvas infectantes das fezes para a pastagem}

As larvas infectantes são ativas, apresentam movimentação errática e aparentemente migram em qualquer direção (Sciacca et al., 2002), inclusive para a vegetação localizada junto das fezes. A capacidade de as larvas de $H$. contortus migrarem no ambiente é grandemente influenciada pelas condições climáticas. A maioria dos estudos conduzidos no campo indica que a migração das larvas para a pastagem aumenta com a ocorrência de chuva e é proporcional à intensidade e frequência das precipitações. A chuva umedece e amolece as fezes, permitindo que as larvas possam sair de dentro dos cíbalos e migrar para a pastagem. Um filme de umidade ao longo do qual a larva possa "nadar" parece ser necessário para que ela migre ao longo das folhas do capim. Porém, mesmo na ausência de chuvas, algumas larvas conseguem se deslocar até as plantas. Nesse caso, a umidade decorrente do orvalho pode ser suficiente para permitir a migração (Santos et al., 2012).

Em condições de baixa umidade, grande número de L3 tende a permanecer nas fezes, e aquelas que atingem a vegetação são encontradas com maior frequência na base das plantas. Por outro lado, durante períodos com umidade elevada e alta temperatura, grande número de L3 tende a se localizar no ápice das forrageiras (Figura 
24), ou seja, chuvas associadas com temperatura elevada favorecem a migração das L3 das fezes para o ápice da forragem (Silva et al., 2008; Santos et al., 2012). Portanto, as condições de umidade e temperatura nos diferentes meses do ano influenciam a migração das larvas de $H$. contortus das fezes para a pastagem. A migração é favorecida pela chuva, por outro lado, na ausência de precipitações, a maioria das larvas permanece nos cíbalos fecais (Silva et al., 2008), que podem se manter íntegros por várias semanas no ambiente, constituindo-se em importante reservatório de larvas infectantes (Rocha, 2006; Carneiro; Amarante, 2008).

Figura 24 - Número médio de larvas infectantes de Haemonchus contortus recuperadas de diferentes estratos de Brachiaria decumbens $(0-10 \mathrm{~cm}, 10-20$ $\mathrm{cm}$ e $>20 \mathrm{~cm}$ ) em diferentes horários do dia (*nascer do sol e **pôr do sol) nos meses de dezembro e junho
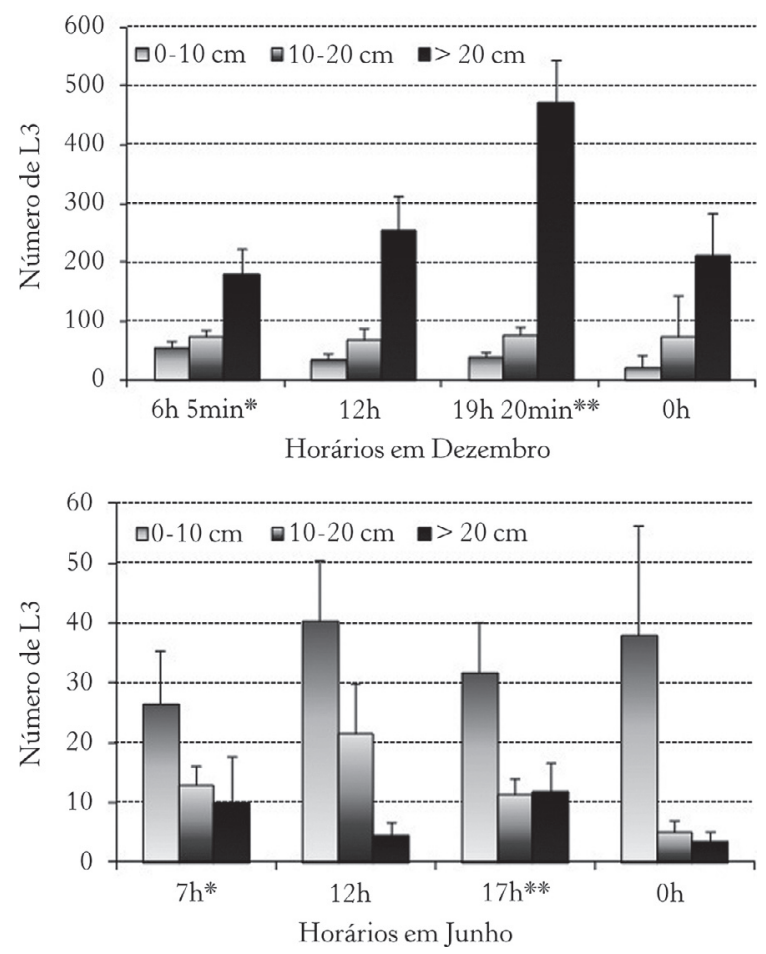

Fonte: Silva et al., 2008. 


\section{Sobrevivência das larvas infectantes no ambiente}

Observa-se que as formas infectantes dos parasitas se comportam de modo a conciliar sua sobrevivência com a maior probabilidade possível de serem ingeridas pelo hospedeiro. No caso de $H$. contortus, a probabilidade de a L3 ser ingerida pelo hospedeiro aumenta se ela migrar das fezes, onde o desenvolvimento inicial ocorre, para a vegetação, que constitui o alimento do ruminante. Portanto, uma fase inicial de migração aumenta grandemente suas chances de encontrar um hospedeiro. Entretanto, uma vez tendo atingido a vegetação, qualquer atividade subsequente não aumentará as chances de encontrar seu hospedeiro. Pelo contrário, movimentação contínua pode resultar em exaustão das reservas energéticas. Por essa razão, após se localizarem na forrageira, as L3 tendem a permanecer imóveis, economizando energia, até que eventualmente sejam ingeridas pelo hospedeiro (Fenton; Rands, 2004).

Ao contrário do que ocorre durante a fase de desenvolvimento (ovo até L3), em que a umidade é essencial, a sobrevivência das L3 não depende de ambiente úmido. As larvas infectantes são capazes de sobreviver a vários ciclos de dessecação/reidratação por um processo conhecido como anidrobiose, no qual a atividade metabólica sofre redução e a sobrevivência é prolongada (Lettini; Sukhdeo, 2006). Por essa razão, elas podem sobreviver por várias semanas na pastagem, especialmente quando a temperatura é amena, com médias em torno de $17^{\circ} \mathrm{C}$ (Carneiro; Amarante, 2008).

A luz ultravioleta tem ação deletéria sobre as larvas (Van Dijk et al., 2009). Essa é uma das razões pelas quais o microclima da pastagem tem grande relevância no desenvolvimento e na sobrevivência larval. Em função do porte e da morfologia das diferentes espécies forrageiras, ambientes distintos podem ser encontrados na base da pastagem com variação na incidência de sol e umidade. Além da cobertura vegetal, o tipo de solo e a quantidade de matéria orgânica também têm influência no microclima. Em solos ricos em matéria orgânica, as minhocas e outros invertebrados, ao consumi- 
rem e incorporarem as fezes ao solo, reduzem a contaminação da pastagem (Niezen et al., 1998). Por outro lado, fezes expostas ao sol secam rapidamente, o que pode resultar em destruição maciça de ovos e larvas, especialmente daquelas de primeiro e segundo estágio, que são mais sensíveis. Experimentalmente, a deposição de amostras fecais de ovinos entre gramíneas com altura reduzida (5 $\mathrm{cm}$ ), que favorecia a incidência direta do sol e a dessecação, resultou em elevada mortalidade dos estágios de vida livre de $H$. contortus e T. colubriformis (Carneiro; Amarante, 2008; Rocha et al., 2008b). O contrário ocorreu quando as amostras fecais foram depositadas em meio a gramíneas com altura mais elevada $(30 \mathrm{~cm})$. Porém, isso não quer dizer que os riscos de infecção são necessariamente menores quando os animais são colocados em uma pastagem baixa. Pois, nesse caso, a concentração de larvas pode ser maior (número de larvas por kg de matéria seca), uma vez que a quantidade de forragem/ $\mathrm{m}^{2}$ também será menor.

Em Botucatu (SP), Carneiro e Amarante (2008) avaliaram a influência de diferentes gramíneas (Brachiaria decumbens cv. Australiana, Cynodon dactylon cv. Coast-cross e Panicum maximum cv. Aruana) no desenvolvimento e sobrevivência de larvas de $H$. contortus. Canteiros com essas variedades de gramíneas foram plantados, e sobre eles foram depositadas amostras de fezes de ovinos que continham ovos de H. contortus, em quatro épocas do ano (agosto, novembro, fevereiro e maio). Observou-se que o período de recuperação de larvas foi mais curto após a deposição de novembro e fevereiro (estação das águas). Por outro lado, temperaturas amenas (em torno de $17^{\circ} \mathrm{C}$ ), associadas com precipitações reduzidas, favoreceram a recuperação de larvas do ambiente. No início de setembro, dezesseis semanas após a deposição realizada em maio, larvas ainda foram recuperadas da pastagem (Tabela 3). Posteriormente, Rocha (2006) conduziu um experimento similar com T. colubriformis, também em Botucatu (SP) (Tabela 4). 
Tabela 3 - Recuperação de larvas infectantes de Haemonchus contortus após a deposição de amostras fecais em meio a três espécies de forrageiras.* Análises realizadas uma, duas, quatro, oito, doze e dezesseis semanas após a contaminação (Carneiro; Amarante, 2008)

\begin{tabular}{l|c|c|c|c}
\hline $\begin{array}{c}\text { Data da } \\
\text { contaminação }\end{array}$ & $\begin{array}{c}\text { Ápice na recuperação } \\
\text { de larvas após a } \\
\text { contaminação }\end{array}$ & \multicolumn{2}{|c}{$\begin{array}{c}\text { Sobrevivência máxima } \\
\text { observada }\end{array}$} \\
\cline { 2 - 5 } & Fezes & Pastagem & Fezes & Pastagem \\
\hline $7 /$ ago./2002 & 2 semanas & 4 semanas & $\begin{array}{c}\text { Até a última } \\
\text { coleta }-16 \\
\text { semanas }\end{array}$ & 8 semanas \\
\hline $6 /$ nov./2002 & $\begin{array}{c}1 \text { e } 2 \\
\text { semanas }\end{array}$ & 2 e 4 semanas & 8 semanas & $\begin{array}{c}\text { Até a última coleta } \\
-16 \text { semanas }\end{array}$ \\
\hline $5 /$ fev./2003 & 1 semana & 2 semanas & 2 semanas & $\begin{array}{c}\text { Até a última coleta } \\
-16 \text { semanas }\end{array}$ \\
\hline $14 /$ maio/2003 & 4 semanas & 8 semanas & $\begin{array}{c}\text { Até a última } \\
\text { coleta }-16 \\
\text { semanas }\end{array}$ & $\begin{array}{c}\text { Até a última coleta } \\
-16 \text { semanas }\end{array}$ \\
\hline
\end{tabular}

*No dia da contaminação, as forrageiras tinham $30 \mathrm{~cm}$ de altura.

Tabela 4 - Recuperação de larvas infectantes de Trichostrongylus colubriformis após a deposição de amostras fecais em meio a três espécies de forrageiras.* Análises realizadas uma, duas, quatro, oito, doze e dezesseis semanas após a contaminação (Rocha, 2006)

\begin{tabular}{l|c|c|c|c}
\hline $\begin{array}{c}\text { Data da } \\
\text { contaminação }\end{array}$ & $\begin{array}{c}\text { Ápice na recuperação } \\
\text { de larvas após a } \\
\text { contaminação }\end{array}$ & \multicolumn{2}{|l}{ Sobrevivência máxima observada } \\
\cline { 2 - 5 } & Fezes & Pastagem & Fezes & Pastagem \\
\hline $5 /$ fev./2004 & 2 semanas & 2 semanas & $\begin{array}{c}\text { Até a última coleta } \\
-16 \text { semanas }\end{array}$ & $\begin{array}{c}\text { Até a última coleta } \\
-16 \text { semanas }\end{array}$ \\
\hline $7 /$ maio/2004 & $\begin{array}{c}2 \text { e } 8 \\
\text { semanas }\end{array}$ & $\begin{array}{c}2 \text { a } 8 \\
\text { semanas }\end{array}$ & $\begin{array}{c}\text { Até a última coleta } \\
-16 \text { semanas }\end{array}$ & 12 semanas \\
\hline $5 /$ ago./2004\# & $\begin{array}{c}12 \\
\text { semanas }\end{array}$ & 2 semanas & $\begin{array}{c}\text { Até a última coleta } \\
-16 \text { semanas }\end{array}$ & 12 semanas \\
\hline $24 /$ nov./2004 & 2 semanas & 2 semanas & 4 semanas & 12 semanas \\
\hline
\end{tabular}

*No dia da contaminação, as forrageiras tinham $30 \mathrm{~cm}$ de altura.

\# Após a contaminação, número reduzido de larvas foi recuperado da pastagem.

\section{Influência da forrageira na biologia dos estágios de vida livre e na migração vertical das larvas infectantes}

As larvas infectantes dos estrongilídeos são ingeridas pelos ovinos juntamente com a pastagem. Portanto, a migração das larvas infectantes das fezes para a pastagem, bem como a sua localização na 
planta, tem papel central na transmissão dos parasitas. Ao avaliar a migração vertical das larvas em diferentes horários do dia, ao nascer do sol, ao meio-dia, ao pôr do sol e à meia-noite, Silva et al. (2008) observaram que a localização das larvas se mantém relativamente constante ao longo do dia, ou seja, não existe um determinado horário em que os ovinos estejam mais predispostos à infecção (Figura 24). Nesse mesmo estudo, a maioria das larvas foi recuperada do extrato superior da forragem (Brachiaria decumbens) nas observações realizadas em setembro e dezembro. Do número total de larvas depositadas, 0,12\% foram recuperadas das amostras fecais, e $0,91 \%$, do capim, no mês de dezembro, e 4,91\% das amostras fecais e $0,16 \%$ do capim, no mês de junho (ibidem). Por outro lado, em março e junho, a maioria das larvas foi recuperada da base da forrageira. Oliveira et al. (2008), ao analisar cinco espécies forrageiras, também encontraram a maior proporção de larvas de $H$. contortus na base das planta em análises realizadas no final do verão. De acordo com os autores, a presença de tricomas nas plantas não tem influência na migração vertical.

Curiosidade: no ambiente, mesmo quando as condições climáticas são favoráveis, apenas um pequeno percentual de ovos dá origem a larvas infectantes capazes de migrar para a pastagem. Apesar da baixa taxa de sobrevivência dos estágios de vida livre, a quantidade de larvas infectantes de $H$. contortus produzidas e encontradas na pastagem é suficiente para causar infecção severa em ovinos susceptíveis. Isso ocorre devido à grande quantidade de ovos que o parasita produz. Sabendo-se que os ovinos eliminam quantidade de fezes que corresponde a aproximadamente $5 \%$ do seu peso vivo (Amarante et al., 2007). Uma ovelha com $50 \mathrm{~kg}$ de peso e apresentando mil ovos por grama de fezes (OPG), por exemplo, eliminará no total aproximadamente 2,5 milhões de ovos por dia. Se apenas 0,01\% desses ovos derem origem a larvas infectantes capazes de sobreviver e migrar até a pastagem, 25 mil larvas atingirão a forragem diariamente.

\section{Ciclo de vida de Strongyloides papillosus}

Em relação ao ciclo geral, é importante destacar que os nematódeos da espécie Strongyloides papillosus apresentam aspectos bioló- 
gicos distintos dos demais representantes desse filo. Não existem machos parasitas, apenas fêmeas, que, por partenogênese, produzem ovos que são eliminados embrionados nas fezes (Figura 25). Porém, no ambiente pode ocorrer a formação de machos e fêmeas adultos de vida livre, as quais produzem ovos, que poderão dar origem a larvas infectantes de terceiro estágio (figuras 26 e 27). Esse fato possibilita ao nematódeo aumentar a sua população de larvas infectantes no ambiente. Porém, as larvas infectantes de S. papillosus, por não apresentarem dupla cutícula, são bastante sensíveis. Outra particularidade desse gênero diz respeito à forma de infecção. Diferentemente da maioria dos nematódeos, as larvas infectantes penetram ativamente na pele dos hospedeiros, caem na circulação sanguínea e chegam aos pulmões, onde mudam para o quarto estágio, são expectoradas, deglutidas e se instalam na mucosa do intestino delgado, onde dão origem a fêmeas adultas. Os animais com poucos dias de vida já podem apresentar infecções patentes por S. papillosus. Na maioria das vezes, as infecções por esses nematódeos são leves e não requerem tratamento com anti-helmíntico. Porém em animais jovens, confinados em condições precárias de higiene, as infecções podem ser pesadas.

Figura 25 - Ovo de Strongyloides papillosus e ovos de Moniezia spp.

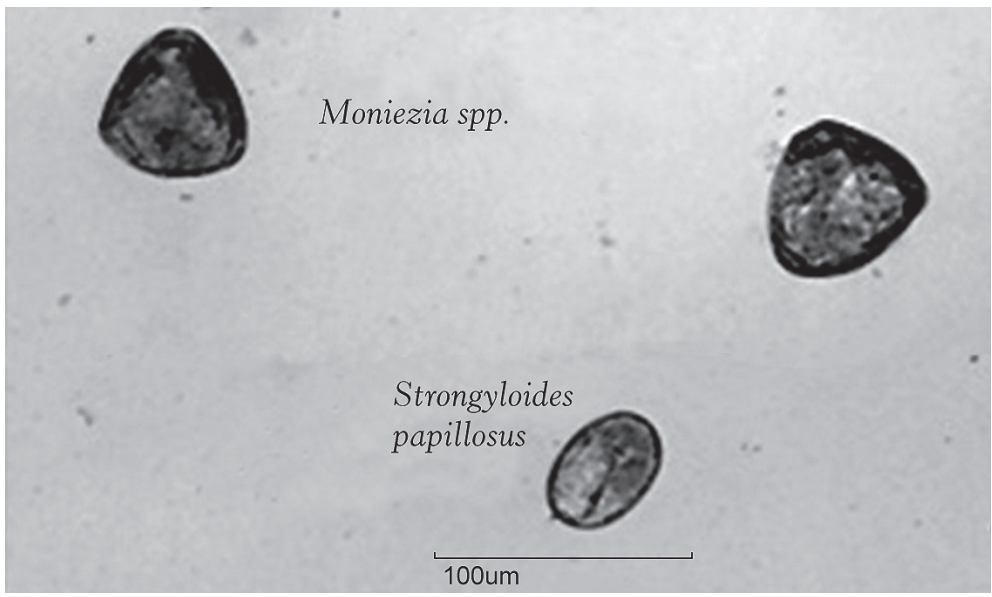


Figura 26 - Larva infectante de Strongyloides papillosus. Obsevar células intestinais (coloração escura) e esôfago filarioide (coloração clara na extremidade anterior). A seta indica o limite entre o esôfago e o intestino

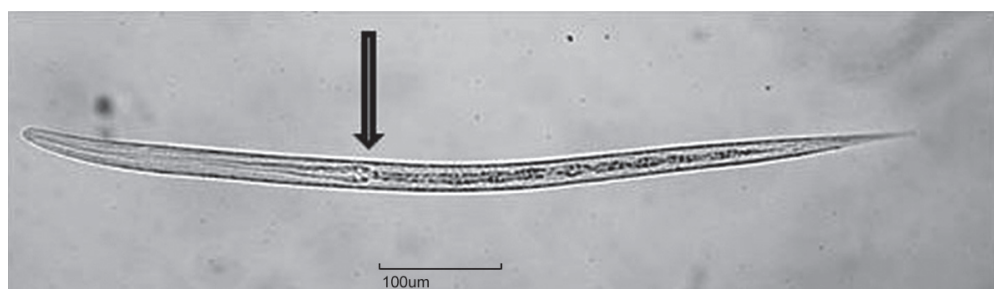

Figura 27 - A larva infectante de Strongyloides papillosus é menor que a larva infectante de Haemonchus contortus

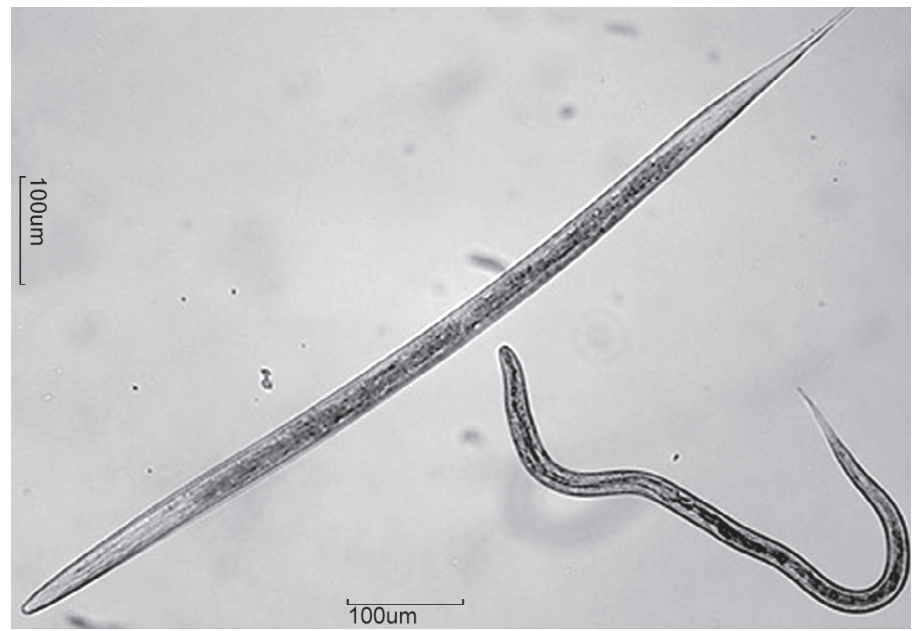

\section{Ciclo de vida de Trichuris spp. e Skrjabinema ovis}

As infecções por Trichuris spp. são usualmente leves e não chegam a causar alterações patológicas perceptíveis. Os animais eliminam nas fezes ovos bioperculatos (Figura 28), e a forma infectante é o ovo larvado. Os adultos são encontrados com a sua extremidade anterior inserida na mucosa do intestino grosso. 
Figura 28 - Ovo de Trichuris spp.

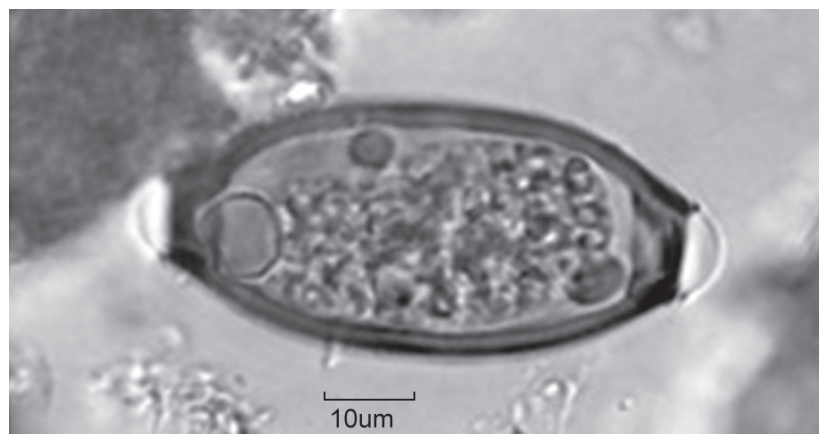

Skrjabinema é um oxiurídeo pouco frequente em ovinos. No estado de São Paulo, esse parasita tem sido detectado apenas em ovinos que compartilham pastagem ou instalações com caprinos. Os ovinos parasitados esfregam a região posterior do corpo contra anteparos, o que indica a ocorrência de prurido devido à oviposição que as fêmeas realizam na região perianal (observações do autor que não foram publicadas). No caso desse parasita, o ovo larvado é a forma infectante para o hospedeiro.

\section{Fase de vida parasitária}

Após serem ingeridas pelo hospedeiro, as larvas infectantes dos estrongilídeos perdem a cutícula externa e se instalam na mucosa. No caso de $H$. contortus, as L3 penetram na mucosa do abomaso, dando início a uma fase de desenvolvimento histotrófico. Poucos dias após a infecção, larvas de quarto estágio inicial já são encontradas na luz do órgão. Após a quarta e última mudança de cutícula, as larvas de quinto estádio (L5) completam o desenvolvimento, amadurecem sexualmente, e, após a cópula, as fêmeas iniciam a oviposição, dando início ao que se denomina "período patente da infecção". Fotos de H. contortus em diferentes estágios de desenvolvimento estão apresentadas na Figura 29. Na Tabela 5 estão indicados os dias em que ocorrem as mudanças de estágio e o período pré-patente da infecção das principais espécies de nematódeos gastrintestinais. 
Figura 29 - Formas imaturas de Haemonchus contortus: (a) extremidade anterior e (b) extremidade posterior de larva em quarto estágio inicial; (c) extremidade posterior de macho em quarto estágio final, imediatamente antes da mudança para o quinto estágio, com raios da bolsa copuladora já formados; (d) extremidade posterior de fêmea em quarto estágio final, imediatamente antes da mudança para o quinto estágio. Observar cutícula externa se desprendendo do corpo da larva; (e) extremidade posterior de fêmea em processo de mudança do quarto para o quinto estágio
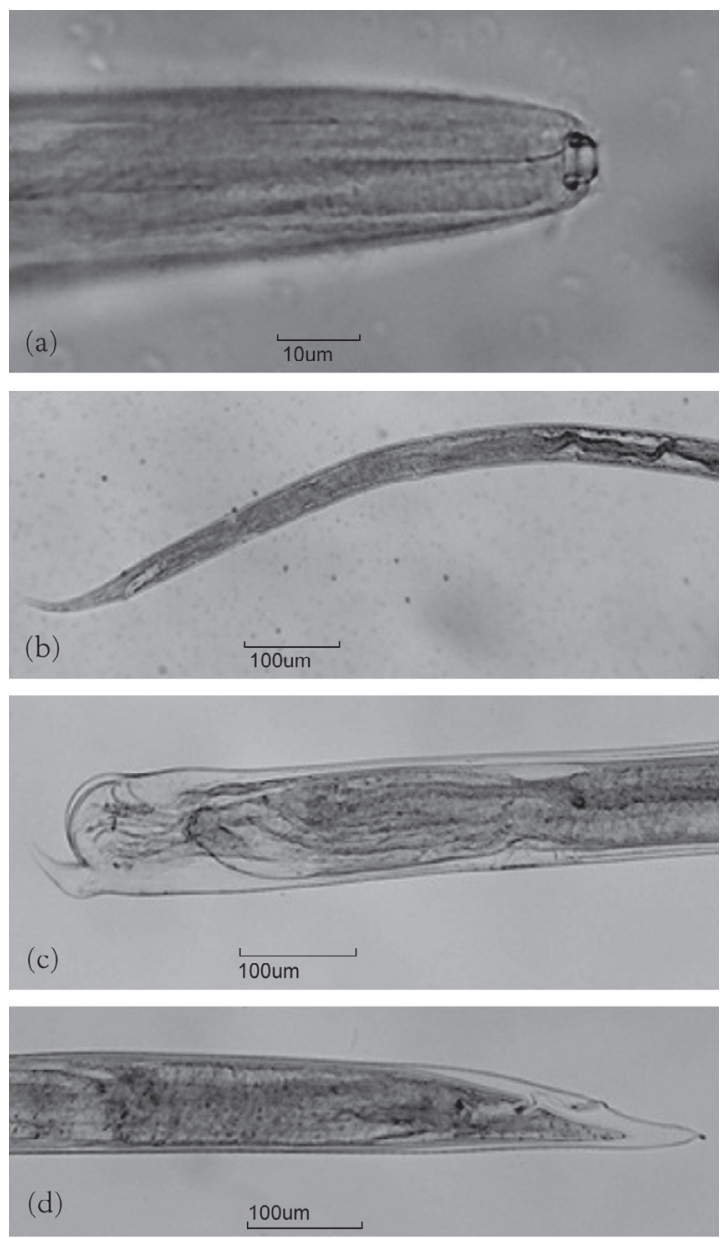

(e) 
Tabela 5 - Tempo (dias) de mudança de estádio larval e patência de nematódeos gastrintestinais em ovinos

\begin{tabular}{l|c|c|c}
\hline \multicolumn{1}{c|}{ Espécie } & $\begin{array}{c}\text { Muda de } \\
\text { L3 para L4 }\end{array}$ & $\begin{array}{c}\text { Muda de L4 } \\
\text { para L5 }\end{array}$ & $\begin{array}{c}\text { Período pré- } \\
\text {-patente }\end{array}$ \\
\hline Haemonchus contortus & $1-5$ & $9-11$ & $18-21$ \\
\hline Teladorsagia circumcincta & 3 & $7-9$ & $17-21$ \\
\hline Trichostrongylus axei & $4-6$ & $10-14$ & 21 \\
\hline Trichostrongylus colubriformis & 3 & $6-9$ & 21 \\
\hline Cooperia spp. & 2 & 8 & $13-14$ \\
\hline $\begin{array}{l}\text { Nematodirus spathiger e } \\
\text { Nematodirus battus }\end{array}$ & $<5$ & $10-12$ & $14-16$ \\
\hline Strongyloides papillosus & 3 & $>6$ & $>9$ \\
\hline Oesophagostomum columbianum & $5-7$ & 21 & $35-42$ \\
\hline Chabertia ovina & $7-8$ & $24-25$ & $42-49$ \\
\hline
\end{tabular}

Fonte: Wood et al., 1995.

\section{Fase de vida parasitária de Oesophagostomum columbianum}

De acordo com Dash (1973), após a ingestão, a larva de terceiro estádio penetra na parede do intestino delgado. A terceira mudança de cutícula de O. columbianum (de L3 para L4) ocorre entre cinco e dez dias após a infecção. Ao final desse período, a maioria das larvas completa seu período de encistamento na parede do intestino delgado, retorna ao lúmem intestinal e migra para o intestino grosso (Figura 30). No intestino grosso, as larvas iniciam uma segunda fase histotrófica no interior da parede intestinal, onde podem ter o desenvolvimento inibido no quarto estágio. As demais larvas parecem se desenvolver diretamente em adultos, no lúmem, sem necessitarem de uma segunda fase de migração nos tecidos. Dois tipos de nódulos macroscópicos se formam na parede do intestino após infecções primárias. Nódulos pequenos se formam no intestino delgado nos locais de encistamento das larvas de terceiro estágio. Nódulos caseosos grandes se formam no intestino grosso em torno da larva de quarto estágio durante a segunda fase histotrófica. 
Portanto, uma mesma larva, em diferentes estágios de desenvolvimento, pode ser responsável por dois tipos de nódulos, em regiões diferentes do intestino.

Poucas larvas dão origem a parasitas adultos após infecções secundárias. Algumas permanecem inibidas em quarto estágio no intestino delgado. Aquelas que completaram a primeira fase histotrófica invariavelmente entram em nova fase histotrófica no intestino grosso. Larvas de quarto estágio com o desenvolvimento inibido no intestino delgado estimulam a formação de nódulos caseosos similares aos provocados no intestino grosso. Assim, os nódulos caseosos são produzidos em reação à presença de larvas de quarto estágio de O. columbianum em um hospedeiro, sensibilizados por uma infecção prévia ou durante a primeira fase histotrófica de uma mesma infecção. As larvas aprisionadas dentro dos nódulos provavelmente morrem com o decorrer do tempo. A segunda fase histotrófica do parasita parece ser uma variação anormal do padrão de ciclo de vida de O. columbianum e indica adaptação pobre da relação parasita-hospedeiro. O período pré-patente varia de 35 a 39 dias após a infecção primária, e de 46 a 47 dias após infecções secundárias (ibidem).

Figura 30 - (a) Larva de quarto estádio de Oesophagostomum columbianum; (b) aspecto da cápsula bucal

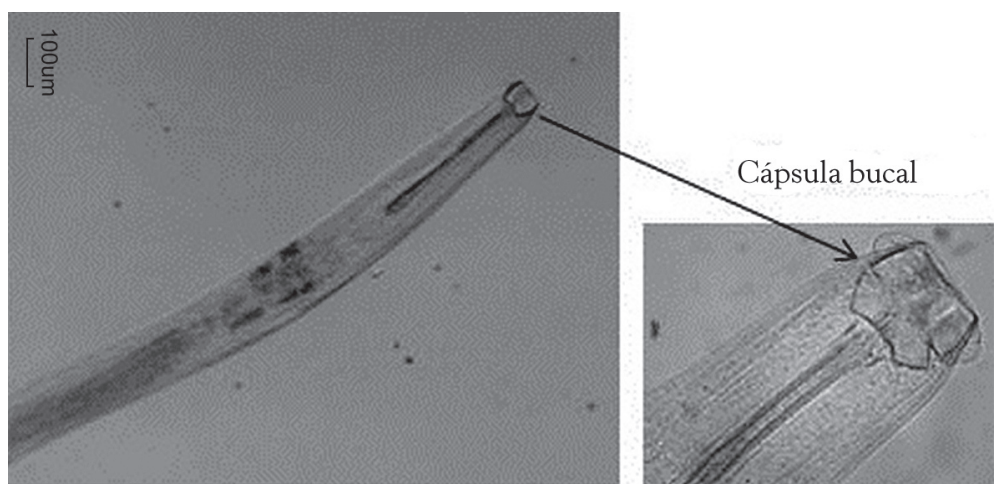




\section{Patogenia das infecções e resposta imunológica contra os nematódeos gastrintestinais}

A ocorrência de problemas clínicos resulta da interação entre o número de larvas infectantes ingeridas diariamente (desafio), o número de parasitas estabelecidos no trato gastrintestinal e a eficiência da resposta imunológica do hospedeiro. Em um rebanho, é impossível prever os animais que permanecerão em boas condições de saúde e aqueles que adoecerão. Geralmente se observa que os animais gravemente acometidos constituem a minoria no rebanho. Isso decorre do fato de a eficiência da resposta imunológica não ser uniforme e ser influenciada por uma série de variáveis, que serão abordadas mais adiante, no tópico "Aspectos epidemiológicos relacionado aos animais".

Em regiões onde animais bem nutridos são expostos permanentemente às infecções, ou seja, diariamente ingerem larvas infectantes em pequena quantidade, pode se estabelecer imunidade protetora. Quando isso ocorre, pode-se afirmar que a relação entre parasita e hospedeiro está em equilíbrio (Amarante, 2001). Porém, essa situação pode se suprimida em casos de estresse, má nutrição e no período do periparto. Além disso, os animais geneticamente predispostos (os susceptíveis) poderão adoecer em consequência de infecções pesadas.

Por outro lado, em regiões onde a exposição dos animais às infecções é sazonal, estes podem permanecer por período prolongado sem ingerir larvas infectantes. Quando as condições ambientais se tornam, de forma repentina, favoráveis ao desenvolvimento e sobrevivência dos estágios de vida livre, podem ocorrer surtos de verminose devido à presença de animais sem a devida proteção contra os parasitas. Isso acontece, por exemplo, após período prolongado de estiagem.

Portanto, a eficiência da resposta imunológica é influenciada por vários fatores, que incluem a espécie do parasita, a taxa de infecção e o tempo de exposição. A resposta imunológica adquirida 
ao longo de desafio contínuo causa redução expressiva na taxa de estabelecimento das larvas infectantes. Cordeiros Santa Inês, por exemplo, submetidos a uma única infecção artificial com 4 mil L3 de Trichostrongylus colubriformis, apresentaram em média 1.473 parasitas adultos quarenta dias após a infecção, isto é, 36,8\% das larvas administradas estabeleceram-se na mucosa intestinal e deram origem a nematódeos adultos (Almeida et al., 2010). Entretanto, quando cordeiros foram infectados com 2.500 L3, três vezes por semana, ao longo de treze semanas (total de 97.500 L3), o percentual de estabelecimento foi muito menor: a maioria dos cordeiros tinha poucos parasitas, de 13 a 1.540 nematódeos, representando estabelecimento inferior a 1,6\% do inóculo (Cardia et al., 2011).

\section{Patogenia e sinais clínicos}

Alguns parasitas se alimentam de sangue, como é o caso de $H$. contortus; outros causam lesões e inflamações na mucosa intestinal, como é o caso de T. colubriformis, S. papillosus e O. columbianum.

Das inúmeras espécies de nematódeos que parasitam ovinos, algumas merecem destaque devido à elevada prevalência e intensidade de infecção. De todas elas, $H$. contortus é uma das mais importantes. A evolução da haemonchose varia muito de animal para animal. Em um extremo têm-se animais que desenvolvem sólida resposta imunológica, capaz de limitar a carga parasitária a apenas alguns poucos parasitas. No outro extremo, animais podem morrer em consequência da anemia severa que ocorre em infecção pesada (Figura 31). H. contortus é hematófago e consome de $0,05 \mathrm{ml}$ a 0,08 $\mathrm{ml}$ de sangue por dia. Portanto, um animal que esteja albergando quinhentos parasitas, infecção considerada relativamente leve, perderá de $25 \mathrm{ml}$ a $40 \mathrm{ml}$ de sangue diariamente. Esse animal, ao final de cinco meses, terá perdido de 3,75 litros a 6 litros de sangue. Já um animal com infecção pesada - 10 mil a 50 mil vermes - poderá perder, diariamente, de 0,5 litro a 4 litros de sangue (Marquardt et al., 2000). 
Figura 31 - (a) Infecção maciça do abomaso por Haemonchus contortus e (b) conjuntiva ocular pálida de cordeiro com anemia severa devido a haemonchose
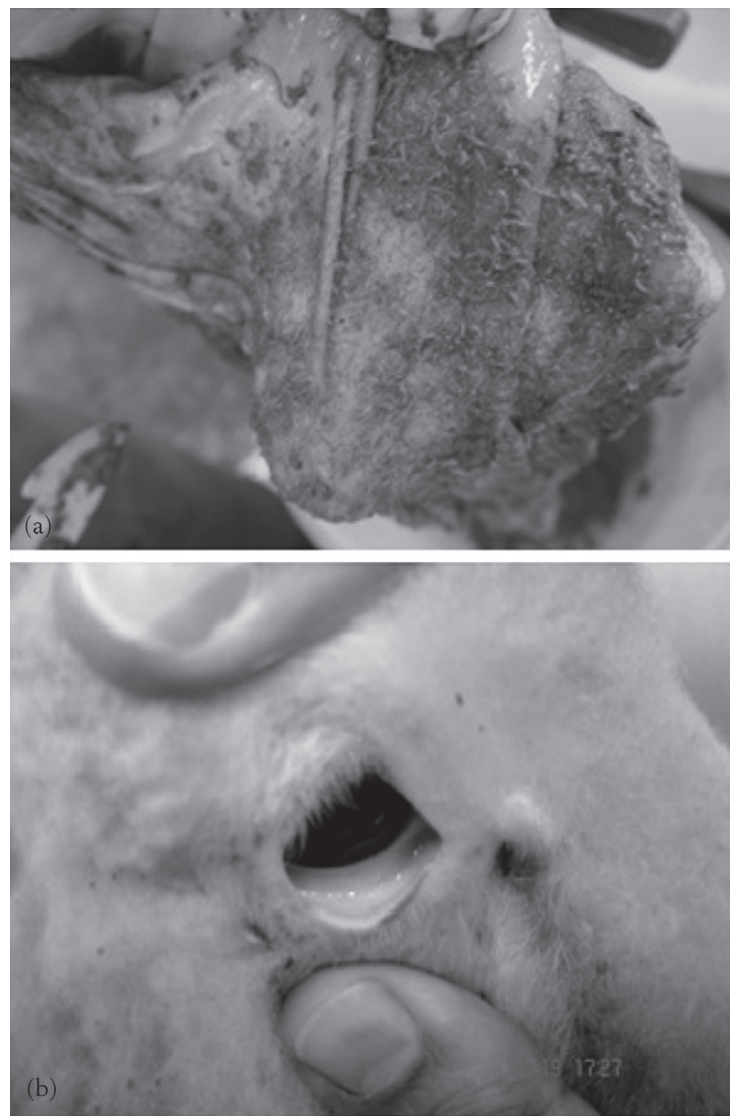

O desenvolvimento da anemia em ovinos infectados experimentalmente com 10 mil L3 de $H$. contortus e reinfectados da mesma maneira de seis a sete semanas depois ocorre em três estágios: (1) durante as três semanas iniciais da infecção ocorre redução progressiva do volume globular (VG), atribuída ao consumo de sangue pelas larvas em desenvolvimento e pelos adultos jovens. Nesse período, a resposta do sistema eritropoético do hospedeiro encontra-se em latência; (2) o segundo estágio (dura de seis a qua- 
torze semanas) pode ser acompanhado de estabilidade do VG, pelo menos em um primeiro momento, e caracteriza-se por hemorragia abomasal contínua e marcado aumento da eritropoese, que se dá à custa das reservas de ferro do animal; o estágio final caracteriza-se por redução dramática do $\mathrm{VG}$, da concentração sérica de ferro e por sinais de exaustão dos mecanismos de síntese, devidos à deficiência de ferro e possivelmente da proteína disponível. No entanto, quatro a oito dias após a reinfecção, alguns animais podem apresentar autocura, acompanhada de recuperação do VG (Dargie; Allonby, 1975).

Cordeiros que apresentavam em média 37\% de VG foram experimentalmente infectados com 4 mil L3 de H. contortus. Dezoito dias após a infecção, o VG era de 30,4\%, e uma semana depois, era de 25,8\% (Figura 32). Valores de VG superiores a 30\% só voltaram a ser registrados quando houve redução das contagens de ovos para níveis inferiores a 3 mil OPG, o que ocorreu mais de três meses após a infecção (dados não publicados).

Figura 32 - Valores de volume globular (VG) e contagem de ovos por grama de fezes (OPG) de cordeiros após a infecção com 4 mil larvas infectantes (L3) de Haemonchus contortus

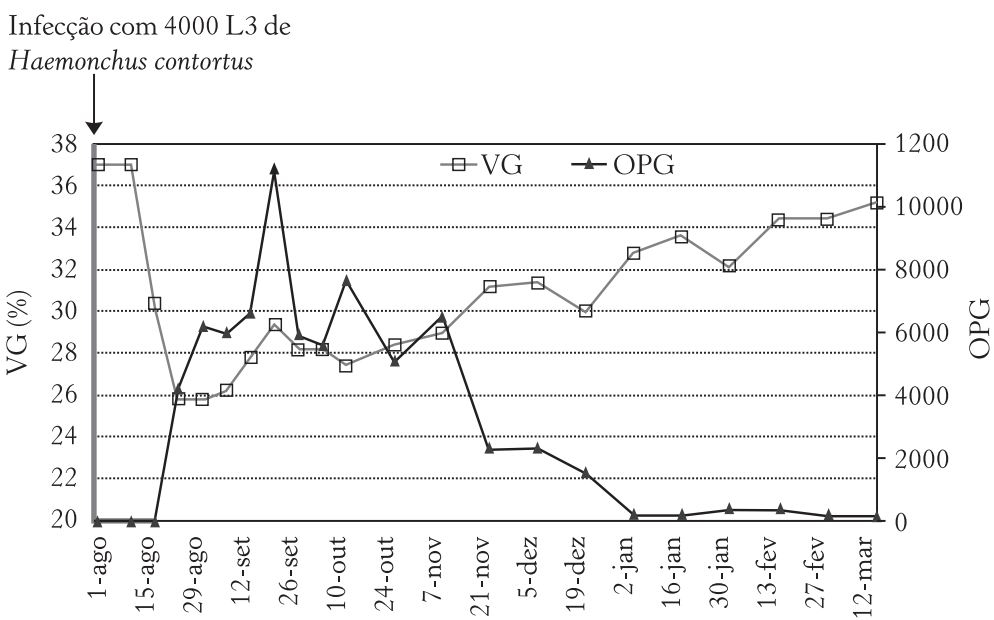


Trichostrongylus colubriformis em infecções pesadas causa enterite severa. A maioria dos parasitas localiza-se no terço inicial do intestino delgado, em túneis no epitélio das vilosidades. Ao formar túneis, os vermes causam necrose do epitélio e alimentam-se do conteúdo das células epiteliais necrosadas (Andronicos et al., 2012). Os danos principais causados nas regiões parasitadas são atrofia das vilosidades, espessamento da mucosa e erosão do epitélio, alterações que comprometem a digestão e a absorção de nutrientes. Os danos nos tecidos intestinais resultam também em perda de líquidos tissulares. Os animais parasitados podem também apresentar redução no consumo de alimento (Holmes, 1985). Os transtornos causados por Cooperia spp. e por S. papillosus são similares aos causados por T. colubriformis.

Oesophagostomum columbianum apresenta elevada patogenicidade. A enfermidade aguda é causada pelas larvas histotróficas do parasita que se localizam na mucosa do intestino, onde causam inflamação a formação de nódulos (Figura 33). As principais manifestações clínicas apresentadas pelos animais parasitados são anorexia, perda de peso, diarreia e anemia (Horak; Clark, 1966). Após reinfecções, os efeitos do parasitismo são menos severos e se devem a resposta imunológica que causa redução no número de larvas capazes de penetrar nos tecidos intestinais (Dobson, 1967).

Figura 33 - Lesões nodulares na parede do intestino de ovino causadas por larvas de Oesophagostomum columbianum

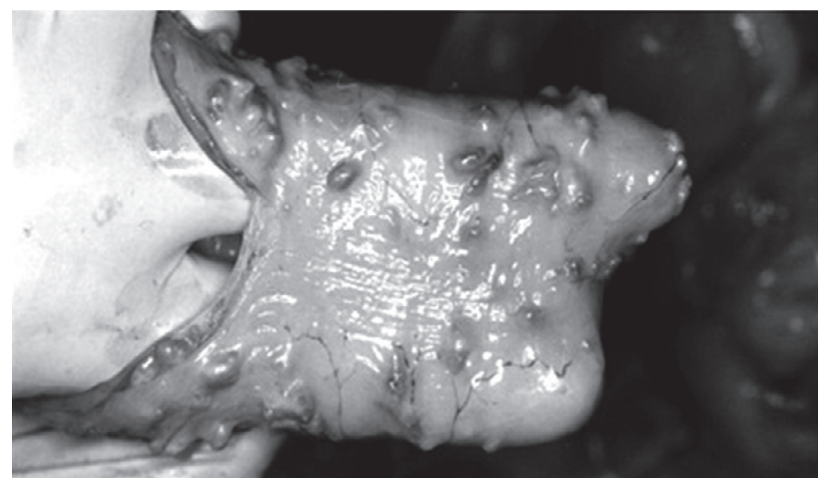


Como as infecções dos animais são, em geral, mistas, ocorre somatório dos efeitos patogênicos de cada uma das espécies que parasitam esses hospedeiros. Em consequência do parasitismo, os principais sinais clínicos apresentados pelos ovinos são anemia, edema submandibular (devido à hipoproteinemia), diarreia, inapetência e perda de peso. Vale ressaltar que as fezes podem se manter com a consistência normal nos casos de infecções pesadas apenas com H. contortus (haemonchose).

\section{Resposta imunológica}

A resistência contra os parasitas envolve mecanismos passivos e ativos. A resistência passiva inclui barreiras físicas e químicas que evitam a entrada do parasita no corpo do hospedeiro ou que criam um ambiente fisiologicamente inadequado para a instalação e desenvolvimento do parasita. A resistência ativa engloba a resposta imunológica inata e/ou adaptativa produzida em resposta à infecção (Saddiqi et al., 2011). Nesse caso, várias moléculas produzidas pelos parasitas, denominadas antígenos, são reconhecidas como estranhas pelo organismo, e, contra elas, o sistema imunológico é ativado, com a participação de células especializadas na defesa que produzem várias substâncias, tais como citocinas e imunoglobulinas (anticorpos).

Os nematódeos induzem resposta mediada por linfócitos Th tipo 2 (Th2), dependente de anticorpos, enquanto parasitas intracelulares (por exemplo, vírus) induzem resposta Th tipo 1 (Th1). Os dois tipos de resposta são importantes, pois os animais são expostos a diferentes patógenos. A resistência contra os nematódeos depende da habilidade do hospedeiro em reconhecer o parasita e elaborar resposta imunológica protetora eficiente do tipo Th2. As células Th2 produzem citocinas que irão estimular a proliferação de outras células inflamatórias, como eosinófilos e mastócitos. Essas mesmas citocinas estimularão a produção de imunoglobulinas contra os parasitas, tais como IgE e IgA. Ocorre também aumento na produção de muco, o qual poderá conter substâncias com ação antiparasitária (Anthony et al., 2007). 
A imunidade contra os nematódeos adultos em ruminantes pode se manifestar pela expulsão da população adulta dos vermes, por alterações na morfologia dos parasitas e pela redução na fecundidade das fêmeas. Já a resistência contra as larvas dos nematódeos manifesta-se pela eliminação das larvas infectantes ou pela inibição do desenvolvimento dos parasitas imaturos, fenômeno conhecido como hipobiose (Balic et al., 2000).

Deve-se destacar que a principal consequência da resposta imunológica é a falha no estabelecimento das larvas infectantes na mucosa do trato gastrintestinal, as quais são eliminadas à medida que tentam penetrar nos tecidos dos hospedeiros. Em um hospedeiro com resposta imunológica eficiente, o contato com os parasitas desencadeia aumento da permeabilidade vascular, da produção de muco e da contratilidade das células musculares. Em conjunto, essas alterações favorecem o aprisionamento das larvas e sua eliminação do trato gastrintestinal, o que é favorecido pelo aumento do peristaltismo. A ocorrência de diarreia é a principal manifestação clínica desses eventos.

Usualmente, o desempenho dos animais que estão respondendo ao desafio por patógenos é inferior ao de animais livres de infecção. Esse fato resulta das alterações patológicas decorrentes da enfermidade e também dos custos e das consequências da resposta imunológica. Acrescente-se, ainda, que a habilidade dos animais de suportar a enfermidade é influenciada por fatores ambientais, sendo que o estado nutricional e fisiológico do animal pode interferir na eficiência da reposta imunológica contra os patógenos (Bishop; Stear, 2003).

Por que alguns animais são resistentes e outros susceptíveis às infecções helmínticas?

A maioria dos estudos sobre o assunto indica que os animais resistentes são aqueles capazes de elaborar, com eficiência, resposta mediada por linfócitos Th2. Experimentos realizados na Austrália com duas linhagens de ovinos da raça Merino, uma selecionada para produzir cordeiros geneticamente resistentes contra os vermes e outra selecionada para produzir animais susceptíveis, demonstraram que os animais resistentes elaboraram com eficiência resposta 
protetora do tipo Th2, ao contrário dos animais susceptíveis (Andronicos et al., 2010). Porém, os resultados são controversos, e em alguns estudos não se observou polarização da resposta Th1 ou Th2 em animais que se tornaram resistentes (Ingham et al., 2008).

\section{Redução na produtividade como consequência do parasitismo}

Com visto anteriormente, as infecções pesadas podem resultar em mortalidade. No entanto, a redução na produtividade do rebanho é a principal consequência da verminose. A Tabela 6 apresenta resultados de animais parasitados que foram mantidos em pastagem e suplementados com ração que continha 18\% de proteína bruta, em quantidade equivalente a $3 \%$ do peso vivo. Devido à boa nutrição, desenvolveram resposta imunológica e não apresentaram sinais clínicos de verminose. No entanto, a redução no ganho em peso é evidente quando se compara esse grupo com animais mantidos livres de infecções parasitárias em confinamento e que tinham acesso a alimentação similar.

Tabela 6 - Ganho médio diário em peso de cordeiros das raças Ile de France e Santa Inês criados confinados, livres de infecções parasitárias, e de cordeiros mantidos em pastagem, expostos a parasitas

\begin{tabular}{l|c|c}
\hline \multicolumn{1}{c|}{ Raça } & Animais livres de parasitas* & Animais parasitados** \\
\hline Ile de France & $256 \mathrm{~g} /$ dia & $200 \mathrm{~g} / \mathrm{dia}$ \\
\hline Santa Inês & $223 \mathrm{~g} / \mathrm{dia}$ & $154 \mathrm{~g} / \mathrm{dia}$ \\
\hline
\end{tabular}

*Animais de grupo-controle, não infectados (Bricarello et al., 2005), e **animais parasitados por Haemonchus contortus, Trichostrongylus colubriformis, Strongyloides papillosus e Oestrus ovis (Silva et al., 2012).

Cordeiros Santa Inês experimentalmente infectados com T. colubriformis apresentaram redução acentuada no ganho em peso e na conversão alimentar (Figura 34). Os cordeiros foram infectados com 2.500 L3, três vezes por semana, ao longo de treze semanas (total de 97.500 L3), e, devido à resposta imunológica, a maioria deles tinha poucos parasitas (de 13 a 1.540 nematódeos). Apesar da carga parasitária relativamente pequena, o grupo infectado apre- 
sentou 37\% de redução no ganho diário em peso (107,3 g/dia), quando comparado com o grupo-controle (171,1 g/dia). O grupo infectado também apresentou a pior conversão alimentar, isto é, cada animal necessitou consumir, em média, 10,1 kg de alimento para ganhar $1 \mathrm{~kg}$ de peso vivo, 31,8\% a mais de consumo em comparação com o grupo-controle (Cardia et al., 2011). Em conclusão, o principal prejuízo causado pela verminose é a redução na produtividade de animais, mesmo daqueles com aspecto saudável.

Figura 34 - Ganho médio diário em peso (a) e conversão alimentar de cordeiros (b). Os animais do grupo infectado foram alimentados ad libitum e receberam, ao longo de treze semanas, 2.500 larvas infectantes de Trichostrongylus colubriformis, três vezes por semana; os "pair-fed" receberam a mesma quantidade de alimento consumido no dia anterior pelo seu par do grupo infectado. O grupo-controle foi mantido livre de infecção e alimentado ad libitum
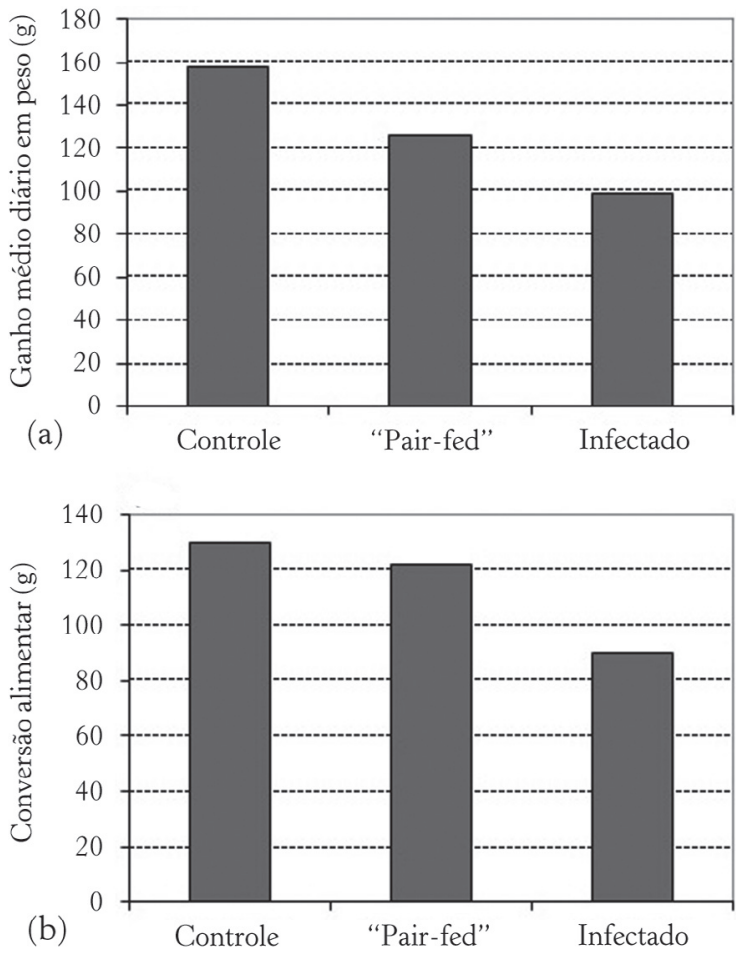

Fonte: Cardia et al., 2011. 


\section{Epidemiologia}

São inúmeros os fatores relacionados à interação entre parasita, hospedeiro e ambiente que podem resultar na ocorrência da verminose ou na redução da produtividade do rebanho. Entre eles, os seguintes se destacam:

\section{Variação sazonal na contaminação da pastagem}

Conforme abordado no item referente aos estágios de vida livre dos nematódeos gastrintestinais, o clima e a vegetação têm grande influência no desenvolvimento e na sobrevivência das larvas, o que resulta em variação sazonal na presença de larvas infectantes na pastagem ao longo do ano. Apesar de tais variações, em muitas regiões, como no estado de São Paulo, os ovinos estão sujeitos a ingerir pastagem contaminada com larvas infectantes em todos os meses do ano (Amarante; Barbosa, 1995, 1998; Amarante et al., 1996; Fernandes et al., 2004; Rocha et al., 2008a). Vale ressaltar que nesse estado, mesmo durante a chamada "estação seca", é comum a ocorrência de chuvas leves e que a umidade relativa do ar média mensal geralmente é superior a 50\% (Amarante; Barbosa, 1995; Fernandes et al., 2004). Nessas condições, embora ocorram variações sazonais no número de larvas na pastagem, a transmissão dos parasitas ocorre ao longo de todo o ano.

Em regiões onde períodos prolongados de estiagem são registrados, como no semiárido nordestino, a transmissão dos parasitas pode ser interrompida por vários meses (Arosemena et al., 1999; Charles, 1989). Porém, vale ressaltar que, mesmo nesses ambientes inóspitos, larvas podem se desenvolver e sobreviver nas margens de açudes e aguadas. Esses locais, por serem frequentados pelos animais em busca de água, costumam apresentar acúmulo de fezes. Nos solos úmidos ao seu redor, a vegetação que se desenvolve pode apresentar elevada contaminação, sendo importante fonte de infecção para os animais. 
Na região Sul do Brasil, a grande amplitude térmica registrada ao longo do ano tem influência na ocorrência das diferentes espécies de nematódeos. No Rio Grande do Sul, H. contortus ocorre em todos os meses do ano, porém com as maiores cargas parasitárias no verão e no outono, enquanto que Trichostrongylus spp. e Ostertagia spp. predominam no inverno e primavera (Santiago et al., 1976; Echevarria et al., 1996). A situação é similar no Planalto Catarinense, $H$. contortus predomina do final da primavera até o início do inverno, com maiores cargas parasitárias no verão, associadas a temperaturas médias superiores a $15^{\circ} \mathrm{C}$ e precipitações pluviométricas superiores a $50 \mathrm{~mm}$. As espécies T. axei e T. colubriformis predominam do outono até o final do inverno, devido a sua adaptação a baixas temperaturas (Ramos et al., 2004).

\section{Aspectos epidemiológicos relacionados aos animais}

A quantidade de ovos de parasitas eliminada nas fezes é inversamente proporcional ao grau de resistência dos animais. Portanto, a eficiência da resposta imunológica tem papel central na epidemiologia da verminose. Uma série de fatores tem influência na eficiência da imunidade e serão abordados a seguir.

\section{Idade e gênero}

A enfermidade pode acometer qualquer animal do rebanho, no entanto, o problema é mais severo em animais jovens e em fêmeas no período do periparto. De forma geral, quanto mais jovem for o animal, maior será sua susceptibilidade à verminose (Colditz et al., 1996). Entretanto, no caso de algumas raças resistentes (vide tópico "Influência da raça ovina e da susceptibilidade individual na resistência às infecções parasitárias”), os cordeiros demonstram precocemente boa capacidade para resistir às infecções parasitárias. O grau de infecção dos cordeiros varia conforme as condições de manejo e o grau de contaminação da pastagem. Em algumas situações são observadas contagens elevadas de ovos nas fezes mesmo 
antes da desmama, ou seja, em animais com menos de dois meses de idade (Rocha et al., 2005).

Excetuando-se o período do periparto, quando aumenta a susceptibilidade das ovelhas à verminose (Amarante et al., 1992b), existem vários estudos que demonstram maior susceptibilidade dos machos inteiros (não castrados), em comparação com as fêmeas (Saddiqi et al., 2011). Cordeiros machos intactos infectados com 5 mil L3 de H. contortus apresentaram maior contagem de OPG, maior carga parasitária e menor valor de VG do que fêmeas de mesma idade. O nível de testosterona plasmática apresentou correlação positiva com a carga parasitária quatro semanas após a infecção, indicando que quanto mais elevado o nível de testosterona, menor a resistência (Gauly et al., 2006).

\section{Influência do manejo e da nutrição}

A situação de equilíbrio na relação entre parasita e hospedeiro pode ser alterada por diversos fatores, que incluem o manejo e a condição nutricional. O rompimento desse equilíbrio é, muitas vezes, produzido inadvertidamente pela ação do próprio ovinocultor. Exemplos de atuação desfavorável são fartos, dentre os quais se pode destacar a superlotação da pastagem, que resulta em elevada contaminação ambiental com os estágios de vida livre dos parasitas. Esse é o caso de pastagens formadas com forrageiras que apresentam elevada produtividade e que permitem a manutenção de número elevado de animais por hectare. Situação ainda pior ocorre quando os animais são mantidos em grande número em áreas que não comportam alta lotação. Nesse caso, além da elevada contaminação, os animais sofrerão com a subnutrição, o que comprometerá o seu desempenho produtivo e a resposta imunológica contra os parasitas. Os animais expostos a altas cargas de parasitas podem sucumbir, especialmente os mais jovens, que são os mais susceptíveis.

A nutrição tem influência direta na eficiência da resposta imunológica e na capacidade dos animais de suportar as infecções. Os 
tecidos responsáveis pela formação de células de defesa, anticorpos e outras substâncias envolvidas na defesa do organismo apresentam grande demanda por nutrientes e só desempenham suas funções adequadamente se houver disponibilidade de nutrientes. Por exemplo, os nódulos linfáticos mesentéricos envolvidos na resposta imunológica contra patógenos intestinais praticamente dobram de peso quando os animais são expostos a infecções com T. colubriformis (Cardia et al., 2011).

As medidas de manejo mais importantes são aquelas que se destinam a suprir adequadamente as necessidades nutricionais dos animais. São duas as categorias que apresentam grande demanda por alimento de qualidade: animais em crescimento e ovelhas no período do periparto. $\mathrm{O}$ alimento fornecido deve ser suficiente para atender às necessidades fisiológicas do animal e também possibilitar, no caso de animais jovens, o desenvolvimento adequado do sistema imunológico. No período do periparto, a demanda por nutrientes aumenta consideravelmente, devido à formação do feto e à produção de leite. Se a quantidade e a qualidade do alimento forem insatisfatórias, os problemas com a verminose podem ser severos.

Nas condições brasileiras de criação de ovinos, sem sombra de dúvidas um dos maiores problemas a ser suplantado é a subnutrição dos animais. Não é pretensão abordar esse assunto com profundidade, o qual é objeto de estudos de especialistas em nutrição e pastagem. No entanto, apenas para exemplificar, para que um cordeiro de uma raça especializada em produção de carne ganhe, após a desmama, $250 \mathrm{~g}$ por dia, ele deverá ter à disposição uma dieta que contenha, entre outros nutrientes, aproximadamente 18\% de proteína bruta (AFRC, 1993). Em regiões com clima temperado, onde predominam pastagens formadas com azevém (gramínea) e trevo (leguminosa), esse valor é facilmente suplantado. No entanto, no Brasil, predominam outras forrageiras (Tabela 7), como Panicum maximum, cujas cultivares Tanzânia e Aruana contêm, em média, respectivamente, $8,7 \%$ e $11,2 \%$ de proteína bruta $(\mathrm{PB})$ na estação das águas (Costa et al., 2007); Paspalum notatum cv. 'tifton 9', com 
$6 \%$ a $12 \%$ de $\mathrm{PB}$, dependendo da idade de crescimento da planta (Vendramini et al., 1999); e Brachiaria decumbens, com 6\% de PB na folha verde (Santos et al., 2004). Se cordeiros forem alimentados exclusivamente com essas forrageiras, não terão suas necessidades nutricionais atendidas, e seu ganho de peso ficará comprometido, bem como a expressão adequada da resposta imunológica.

Tabela 7 - Teor de proteína bruta de gramíneas forrageiras avaliadas na região do Vale do Paraíba (SP)

\begin{tabular}{l|c|c|c}
\hline \multirow{2}{*}{ Nome científico } & \multirow{2}{*}{ Nome vulgar } & \multicolumn{2}{|c}{ Proteína bruta (\%) } \\
\cline { 3 - 4 } & & Inverno & Verão \\
\hline Brachiaria ruziziensis & Ruziziensis & 7,3 & 9,8 \\
\hline Brachiaria decumbens & Braquiária & 5,4 & 7,0 \\
\hline Brachiaria brizantha & Braquiarão & 6,8 & 7,2 \\
\hline Panicum maximum & Makueni & 7,3 & 8,1 \\
\hline Panicum maximum & Tobiatã & 6,5 & 7,2 \\
\hline Panicum maximum & Colonião & 5,9 & 7,4 \\
\hline Cynodon dactylon & Coastcross & 7,3 & 9,5 \\
\hline Cynodon nlemfuensis & Estrela & 5,8 & 7,3 \\
\hline Chloris gayana & Rhodes & 6,5 & 10,2 \\
\hline Andropogon gayanus & Andropógon & 5,8 & 8,3 \\
\hline Setaria anceps & Setária & 8,1 & 8,8 \\
\hline
\end{tabular}

Fonte: Botrel et al., 2002.

Ao estudar a interação entre nutrição e parasitismo, Coop e Kyriazakis (1999) formularam a hipótese de que ocorre competição entre as várias funções corporais pela alocação de nutrientes, especialmente quando eles são escassos. A princípio, a fim de assegurar a sobrevivência, o combate contra os parasitas e a recuperação dos tecidos lesados têm prioridade em relação às demais funções corporais. Porém, em algumas circunstâncias não é isso o que se observa: o crescimento, a prenhez e a lactação têm prioridade, em detrimento da expressão da imunidade. Isso explicaria, em parte, a grande susceptibilidade dos animais nessas fases. À medida que melhora a qualidade da nutrição, aumenta a capacidade do animal 
de tolerar o parasitismo. Além disso, é importante frisar que animais de raças com alto potencial de crescimento apresentam menor expressão de imunidade adquirida em comparação com raças com menor potencial, quando comparadas sob as mesmas condições de nutrição (ibidem).

Os prejuízos decorrentes da subnutrição são agravados quando se opta por criar animais com elevado potencial produtivo, geralmente de raças importadas de regiões com clima temperado, adaptadas a condições climáticas e alimentares completamente distintas das existentes no Brasil. A associação de subnutrição mais contaminação elevada da pastagem pode ter efeito desastroso, com elevada mortalidade de animais. Nesses casos, costuma-se culpar a verminose pelos problemas, quando na realidade o insucesso econômico da atividade deve-se aos vários equívocos e falhas no planejamento da atividade.

A condição nutricional dos animais tem grande influência nas consequências do parasitismo. Ovinos mantidos em plano nutricional elevado apresentam maior tolerância (resiliência), ou seja, maior capacidade para enfrentar as consequências adversas do parasitismo, bem como maior resistência imunológica, a qual pode impor limite ao estabelecimento de larvas infectantes, afetar o crescimento e a fecundidade dos nematódeos e, até mesmo, causar a eliminação dos parasitas presentes (idem, 2001).

Em comparação com animais livres de infecção, ovinos parasitados requerem quantidade extra de proteína metabolizável (PM) para reparar ou substituir os tecidos danificados, bem como para a expressão da resposta imunológica (Kyriazakis; Houdijk, 2006). Estima-se que as necessidades de proteína metabolizável de cordeiros em crescimento e de ovelhas no periparto aumentem entre $20 \%$ e $25 \%$ quando os animais são expostos às infecções (ibidem).

No caso de cordeiros, as dietas com nível elevado de proteína propiciam melhora na resposta imunológica, especialmente daquelas raças que já são naturalmente mais resistentes à haemonchose, como se observou em experimento realizado com cordeiros Santa Inês e Ile de France submetidos a dietas com diferentes teores de 
proteína (Bricarello et al., 2005). Nesse experimento, observou-se maior resistência apenas no grupo de animais Santa Inês que receberam alimento com teor proteico elevado (Figura 35).

Figura 35 - Número médio de nematódeos em cordeiros das raças Ile de France (IF) e Santa Inês (SI) artificialmente infectados com H. contortus e alimentados com dietas isoenérgeticas com teor alto (AP) ou baixo (BP) de proteína bruta, $18 \%$ e $10 \%$, respectivamente (ibidem)

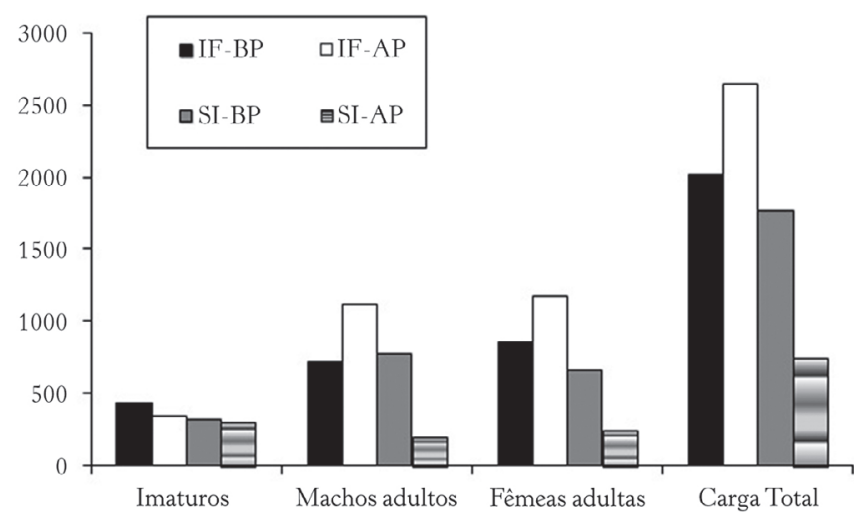

A suplementação proteica propiciou redução no grau de infecção por helmintos e melhora no desempenho de cordeiros Santa Inês mantidos em pastagem no Distrito Federal (Louvandini et al., 2006). Da mesma forma, cordeiros que receberam dieta balanceada apresentaram maior resistência à infecção por Oesophagostomum columbianum, em comparação com animais que receberam dieta com baixo teor de proteína (Dobson; Bawden, 1974).

Em Nova Odessa (SP), cordeiras mantidas durante a estação seca em capim Aruana com 13,2\% de proteína bruta ou em capim Tânzania com 11,1\% de proteína bruta apresentaram desempenho similar. Por outro lado, durante a estação chuvosa, quando os capins Aruana e Tanzânia apresentaram, respectivamente, 11,2\% e $8,5 \%$ de proteína bruta, os animais mostraram-se mais resistentes à verminose e com melhor desempenho quando mantidos no capim Aruana, ou seja, quando alimentados com a forragem que continha o maior teor de proteína bruta (Costa et al., 2007). 


\section{Período do periparto}

No período do periparto, as ovelhas tornam-se mais susceptíveis a infecções por nematódeos gastrintestinais, o que provoca aumento no número de ovos eliminado nas fezes e, consequentemente, da contaminação da pastagem. O fenômeno do periparto é devido ao aumento na fecundidade dos vermes adultos, à retomada do desenvolvimento de larvas hipobióticas ${ }^{1}$ e ao estabelecimento de novas larvas infectantes, sendo que os dois últimos acarretam marcado aumento na carga parasitária de helmintos adultos (O'Sullivan; Donald, 1970). Após a desmama dos cordeiros, a resposta imunológica se restabelece, o que provoca redução acentuada nas contagens de OPG (Amarante et al., 1992b). Na Figura 36 estão apresentados dados relativos à contagem de OPG de ovelhas de quatro raças, na qual se evidencia maior resistência das ovelhas Romney-Marsh à verminose. Após a desmama dos cordeiros, observa-se em todas elas redução acentuada das médias de OPG.

É interessante salientar que o fenômeno do periparto apresenta intensidade variável conforme a raça ovina. Nas raças ovinas que apresentam maior resistência aos nematódeos, o fenômeno do periparto, quando ocorre, é mais discreto do que o observado em raças ovinas susceptíveis (Donald et al., 1982; Courtney et al., 1984; Wanyangu et al., 1997; Amarante et al., 1999b; Rocha et al., 2004a).

Em estudos com ovelhas no periparto, observou-se que ovelhas Ile de France apresentaram maior susceptibilidade à verminose do que fêmeas Santa Inês, tanto em condições naturais como em condições artificiais de infecção por nematódeos gastrintestinais (Rocha et al., 2004a; 2011).

1 Hipobiose é a interrupção do desenvolvimento dos estágios imaturos dos nematódeos nos tecidos do hospedeiro, geralmente no quarto estágio inicial. As condições climáticas adversas são citadas como causa de hipobiose, mas, provavelmente, a principal causa de indução da hipobiose, em espécies de parasitas que ocorrem no Brasil, seja a resposta imunológica do hospedeiro. 
Figura 36 - Contagem média de ovos por grama de fezes (OPG) de ovelhas de quatro raças no final da gestação, durante a lactação e após a desmama dos cordeiros

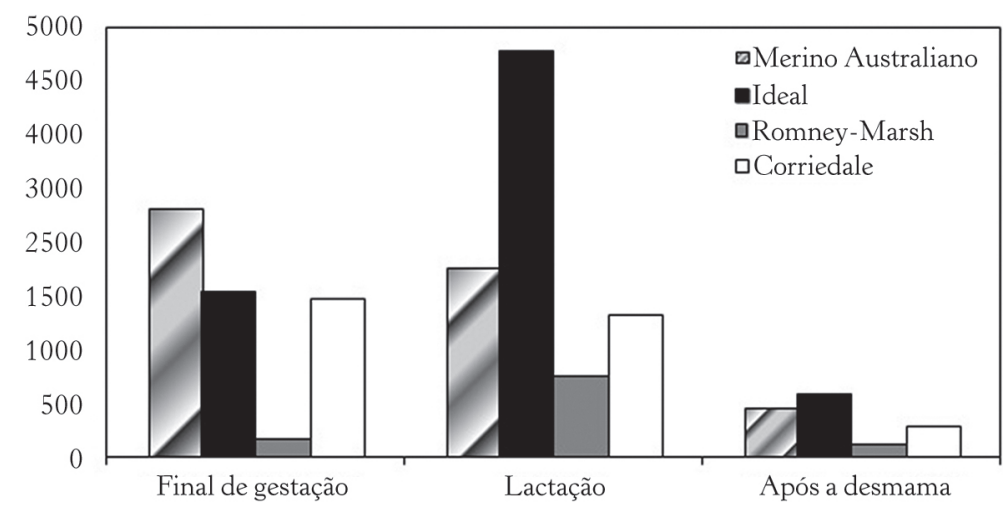

Fonte: Amarante et al., 1992b.

Por que ocorre aumento da susceptibilidade das ovelhas no periparto?

Não se sabe exatamente o que provoca o aumento da susceptibilidade das ovelhas nesse período. $\mathrm{O}$ fenômeno do periparto deve-se provavelmente à interação de vários fatores, que incluem alterações hormonais associadas a necessidades nutricionais elevadas das ovelhas em final de gestação e durante a lactação. As ovelhas apresentam requerimento relativamente elevado de proteína metabolizável (PM) no final da gestação e durante a lactação. As proteínas podem ser consideradas um nutriente escasso, e seu consumo geralmente é insuficiente para atender à demanda do animal nesse período (Coop; Kyriazakis, 2001). Em situação de escassez, a proteína metabolizável é alocada prioritariamente para a produção de leite, em detrimento da resposta imunológica. Ao avaliar dietas com diferentes teores de PM, Houdijk et al. (2003) observaram que os primeiros incrementos em PM resultaram em aumento na produção de leite, e apenas o último incremento (1,25 vez as necessidades de $\mathrm{PM}$ ) resultou em redução na carga parasitária, quando a produção de leite já havia atingido o máximo. Essa suplementação também 
propiciou elevação nos níveis de IgA plasmática anti-L3 de T. circumcincta. Além disso, o efeito da suplementação foi mais pronunciado em ovelhas com gêmeos do que em ovelhas com cordeiro único (idem, 2001). Embora a suplementação proteica tenha um custo relativamente elevado, possibilita que as fêmeas suplementadas aumentem a produção de leite, o que resulta em maior ganho de peso dos cordeiros. Devido à redução provocada na eliminação de ovos de nematódeos pelas ovelhas, ocorre redução da contaminação ambiental por larvas infectantes, o que também é benéfico para os cordeiros (idem, 2003). Dessa forma, a suplementação proteica de ovelhas no periparto pode ser utilizada como uma medida para reduzir a dependência do uso de anti-helmínticos para o controle da verminose.

Nível nutricional elevado durante o início da gestação pode também aumentar a expressão de imunidade contra nematódeos gastrintestinais por ocasião do parto. Ovelhas que receberam dieta rica em energia no início da gestação apresentaram aumento nas reservas de gordura corporal e foram capazes de apresentar maior resistência contra $H$. contortus em comparação com ovelhas que apresentaram reservas menores (Valderrábano et al., 2006).

\section{Influência da raça ovina e da susceptibilidade individual na resistência a infecções parasitárias}

A habilidade de os ovinos adquirirem e expressarem imunidade contra os nematódeos gastrintestinais é controlada geneticamente e varia substancialmente entre as diferentes raças, bem como entre os indivíduos de uma mesma raça (Stear; Murray, 1994). Por um processo de seleção natural, as raças resistentes adaptaram-se em locais com alimentação usualmente precária, onde raças selecionadas para elevada produtividade têm séria dificuldade em sobreviver. Além disso, no processo de seleção natural, sobreviveram os animais capazes de resistir aos parasitas comuns em seu ambiente.

Algumas raças de ovinos demonstram elevado grau de resistência contra as infecções por nematódeos gastrintestinais (Tabela 8), sendo esse o caso das raças Florida Native, St. Croix, Barbados 
Blackbelly e Gulf Coast Native. Os ovinos dessas raças desenvolvem precocemente resistência contra os nematódeos (Courtney et al., 1985; Gamble; Zajac, 1992; Bahirathan et al., 1996). Os ovinos Gulf Coast Native, por exemplo, desenvolvem resistência contra $H$. contortus antes da desmama, durante sua primeira exposição à infecção (Bahirathan et al., 1996). A diferença entre a resistência é mais pronunciada antes da puberdade, quando os cordeiros de raças comerciais apresentam elevada susceptibilidade (Courtney et al., 1985).

Tabela 8 - Raças ovinas criadas no exterior que apresentaram experimentalmente resistência contra infecções por nematódeos gastrintestinais

\begin{tabular}{|c|c|c|c|c|}
\hline $\begin{array}{c}\text { Raça } \\
\text { resistente }\end{array}$ & Origem & $\begin{array}{c}\text { Raça susceptível } \\
\text { na comparação }\end{array}$ & Infecção & Referências \\
\hline $\begin{array}{l}\text { Florida } \\
\text { Native }\end{array}$ & EUA & $\begin{array}{l}\text { Rambouillet; } \\
\text { Hampshire }\end{array}$ & $\begin{array}{c}H . \\
\text { contortus }\end{array}$ & $\begin{array}{l}\text { Radhakrishnan et al. } \\
\text { (1972); Bradley et al. } \\
\text { (1973); Amarante et } \\
\text { al. (1999a) }\end{array}$ \\
\hline $\begin{array}{l}\text { Florida } \\
\text { Native }\end{array}$ & EUA & $\begin{array}{l}\text { Rambouillet; } \\
\text { Finn-Dorset x } \\
\text { Rambouillet; } \\
\text { Dorset x } \\
\text { Rambouillet }\end{array}$ & Mista & $\begin{array}{l}\text { Courtney et al. } \\
\text { (1984); Zajac et al. } \\
\text { (1988); Amarante et } \\
\text { al. (1999a; 1999b) }\end{array}$ \\
\hline $\begin{array}{l}\text { Gulf } \\
\text { Coast } \\
\text { Native }\end{array}$ & EUA & Suffolk & Mista & $\begin{array}{l}\text { Bahirathan et al. } \\
\text { (1996); Miller et } \\
\text { al. (1998); Li et al. } \\
\text { (2001) }\end{array}$ \\
\hline St. Croix & Caribe & $\begin{array}{l}\text { Rambouillet; } \\
\text { Finn-Dorset x } \\
\text { Rambouillet; } \\
\text { Dorset }\end{array}$ & Mista & $\begin{array}{c}\text { Courtney et al. } \\
\text { (1984); Mansfield } \\
\text { e Gamble (1995); } \\
\text { Gamble e Zajac } \\
(1992)\end{array}$ \\
\hline $\begin{array}{l}\text { Barbados } \\
\text { Blackbelly }\end{array}$ & Caribe & INRA 401 & $\begin{array}{c}H . \\
\text { contortus }\end{array}$ & $\begin{array}{c}\text { Aumont et al. (2003); } \\
\text { Terefe et al. (2007) }\end{array}$ \\
\hline $\begin{array}{l}\text { Barbados } \\
\text { Blackbelly }\end{array}$ & Caribe & $\begin{array}{l}\text { Rambouillet; } \\
\text { Finn-Dorset x } \\
\text { Rambouillet; } \\
\text { Dorset }\end{array}$ & Mista & $\begin{array}{c}\text { Yazwinski et al. } \\
\text { (1979); Courtney et } \\
\text { al. (1984) }\end{array}$ \\
\hline Criollo & México & Suffolk & $\begin{array}{c}H . \\
\text { contortus }\end{array}$ & $\begin{array}{c}\text { Alba-Hurtado et al. } \\
\text { (2010) }\end{array}$ \\
\hline
\end{tabular}


Tabela 8 - Continuação

\begin{tabular}{c|c|c|c|c}
\hline $\begin{array}{c}\text { Red } \\
\text { Maasai }\end{array}$ & África & $\begin{array}{c}\text { Blackheaded } \\
\text { Somali; Dorper; } \\
\text { Romney } \\
\text { Marsh; Merino; } \\
\text { Corriedale; } \\
\text { Hampshire }\end{array}$ & $\begin{array}{c}\text { H. } \\
\text { contortus }\end{array}$ & $\begin{array}{c}\text { Preston e Allonby } \\
\text { (1979); Mugambi } \\
\text { et al. (1996; 1997); } \\
\text { Wanyangu et al. } \\
(1997)\end{array}$ \\
\hline $\begin{array}{c}\text { Red } \\
\text { Maasai }\end{array}$ & África & Dorper & Mista & Baker et al. (1999) \\
\hline Sabi & Zimbábue & Dorper & Mista & Matika et al. (2003) \\
\hline $\begin{array}{c}\text { Canária } \\
\text { Deslanada }\end{array}$ & Canárias & Canária & $\begin{array}{c}\text { H. } \\
\text { contortus }\end{array}$ & González et al. (2008) \\
\hline $\begin{array}{c}\text { Scottish } \\
\text { Blackface }\end{array}$ & Escócia & Finn Dorset & $\begin{array}{c}\text { H. } \\
\text { contortus }\end{array}$ & $\begin{array}{c}\text { Altaif e Dargie } \\
\text { (1978a; 1978b) }\end{array}$ \\
\hline
\end{tabular}

\section{Raças brasileiras}

Os estudos sobre a resistência de raças brasileiras de ovinos aos parasitas são relativamente recentes. A maioria dos estudos publicados envolve a raça Santa Inês (Tabela 9). Essa raça demonstrou maior resistência à verminose, em comparação com raças lanadas comerciais, em experimentos realizados nos estados de São Paulo, Rio de Janeiro e Paraná. Os resultados foram coincidentes, independentemente da categoria avaliada e do tipo de infecção, natural ou artificial. $\mathrm{O}$ único estudo em que a raça Santa Inês mostrou-se comparativamente mais susceptível foi realizado no Distrito Federal (McManus et al., 2009). Nesse trabalho, demonstrou-se maior resistência da raça Morada Nova, casualmente uma das raças utilizadas na formação da raça Santa Inês. Esse fato chama a atenção para a necessidade de estudos mais detalhados sobre a resistência da raça Morada Nova. Em relação a estudos com as demais raças naturalizadas brasileiras, em Bagé (RS), cordeiros da raça Crioula Lanada mostraram-se mais resistentes a infecções naturais e artificiais por $H$. contortus do que cordeiros Corriedale (Bricarello et al., 2002; 2004).

A introdução de animais de raças provenientes de regiões de clima temperado, que são susceptíveis a infecções por algumas espécies de parasitas abundantes em regiões tropicais, pode dificultar a profilaxia da verminose (Figura 37). Esses animais, por 
serem considerados de alta produtividade, acabam, muitas vezes, substituindo raças adaptadas às condições de criação dos trópicos.

Figura 37 - Número médio de exemplares de H. contortus e T. colubriformis em cordeiros das raças Santa Inês, Suffolk e Ile de France naturalmente infectados por nematódeos gastrintestinais

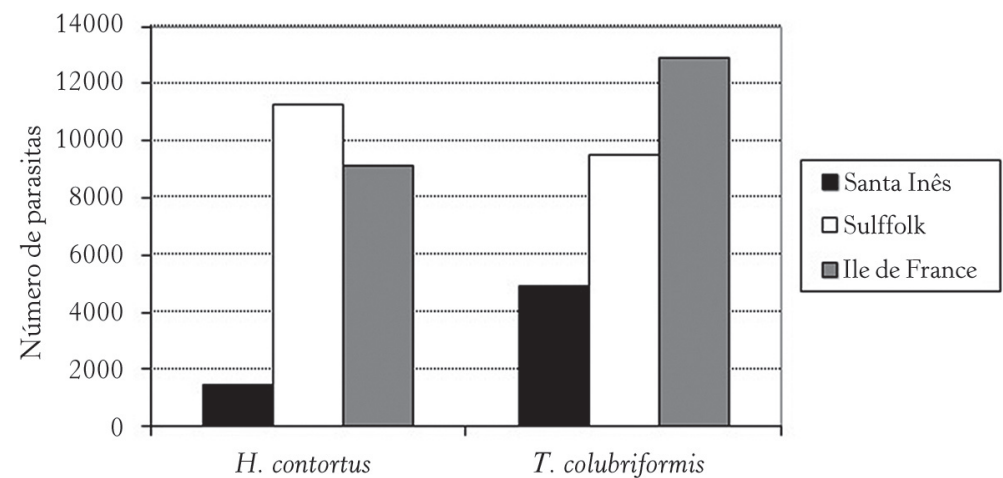

Fonte: Amarante et al., 2004.

Tabela 9 - Raças ovinas criadas no Brasil que apresentaram comparativamente maior e menor grau de resistência contra infecções por nematódeos gastrintestinais

\begin{tabular}{|c|c|c|c|c|c|}
\hline $\begin{array}{c}\text { Raça } \\
\text { resistente }\end{array}$ & $\begin{array}{c}\text { Raça } \\
\text { susceptível na } \\
\text { comparação }\end{array}$ & $\begin{array}{c}\text { Categoria } \\
\text { avaliada }\end{array}$ & $\begin{array}{l}\text { Tipo de } \\
\text { infecção }\end{array}$ & $\begin{array}{c}\text { Principais } \\
\text { parasitas }\end{array}$ & Referências \\
\hline $\begin{array}{l}\text { Romney } \\
\text { Marsh }\end{array}$ & $\begin{array}{l}\text { Merino; Ideal; } \\
\text { Corriedale }\end{array}$ & $\begin{array}{l}\text { Ovelhas no } \\
\text { periparto }\end{array}$ & Natural & $\mathrm{H} ; \mathrm{T}$ & $\begin{array}{l}\text { Amarante et } \\
\text { al. (1992b) }\end{array}$ \\
\hline Crioula & Corriedale & Cordeiros & Artificial & $\mathrm{Hc}$ & $\begin{array}{l}\text { Bricarello et } \\
\text { al. (2002) }\end{array}$ \\
\hline Crioula & Corriedale & Cordeiros & Natural & $\mathrm{Hc}$ & $\begin{array}{l}\text { Bricarello et } \\
\text { al. (2004) }\end{array}$ \\
\hline Santa Inês & Suffolk & Ovelhas & Natural & $\mathrm{H} ; \mathrm{T}$ & $\begin{array}{c}\text { Moraes et al. } \\
(2000)\end{array}$ \\
\hline Santa Inês & $\begin{array}{l}\text { Suffolk; Ile de } \\
\text { France; Poll } \\
\text { Dorset }\end{array}$ & Ovelhas & Natural & $\mathrm{H} ; \mathrm{T}$ & $\begin{array}{c}\text { Bueno et al. } \\
\quad(2002)\end{array}$ \\
\hline Santa Inês & Ile de France & Cordeiros & Artificial & $\mathrm{Hc}$ & $\begin{array}{l}\text { Bricarello et } \\
\text { al. (2005) }\end{array}$ \\
\hline Santa Inês & $\begin{array}{l}\text { Ile de France; } \\
\text { Suffolk }\end{array}$ & Cordeiros & Natural & $\begin{array}{c}\text { Hc; Tc; } \\
\text { Sp; Cc; Oc }\end{array}$ & $\begin{array}{c}\text { Amarante et } \\
\text { al. (2004) }\end{array}$ \\
\hline
\end{tabular}


Tabela 9 - Continuação

\begin{tabular}{c|c|c|l|c|c}
\hline Santa Inês & Ile de France & $\begin{array}{c}\text { Ovelhas no } \\
\text { periparto }\end{array}$ & Natural & $\begin{array}{c}\text { Hc; Tc; } \\
\text { Cc; Oc }\end{array}$ & $\begin{array}{c}\text { Rocha et al. } \\
(2004 \mathrm{a})\end{array}$ \\
\hline Santa Inês & $\begin{array}{c}\text { Suffolk; Ile de } \\
\text { France; }\end{array}$ & Cordeiros & Natural & Hc; Tc & $\begin{array}{c}\text { Costa et al. } \\
(2007)\end{array}$ \\
\hline Santa Inês & Ile de France & $\begin{array}{c}\text { Cordeiros } \\
\text { lactentes }\end{array}$ & Natural & H & $\begin{array}{c}\text { Rocha et al. } \\
(2005)\end{array}$ \\
\hline $\begin{array}{c}\text { Santa Inês, } \\
\text { SRD e } \\
\text { Bergamácia }\end{array}$ & Lacaune & Ovelhas & Natural & H; T & $\begin{array}{c}\text { Silva e } \\
\text { Fonseca } \\
(2011)\end{array}$ \\
\hline $\begin{array}{c}\text { Santa Inês } \\
\text { Santa Inês }\end{array}$ & $\begin{array}{c}\text { Ile de France } \\
\text { Tergamácia }\end{array}$ & $\begin{array}{c}\text { Ovelhas no } \\
\text { periparto }\end{array}$ & Ortificial & Hc & $\begin{array}{c}\text { Rocha et al. } \\
(2011)\end{array}$ \\
\hline $\begin{array}{c}\text { Morada } \\
\text { Nova }\end{array}$ & $\begin{array}{c}\text { Santa Inês; } \\
\text { Ile de France; } \\
\text { Bergamácia }\end{array}$ & Cordeiros & Natural & - & $\begin{array}{c}\text { Mexia et al. } \\
(2011)\end{array}$ \\
\hline
\end{tabular}

$\mathrm{H}=$ Haemonchus spp.; $\mathrm{T}=$ Trichostrongylus spp.; $\mathrm{Hc}=$ Haemonchus contortus $; \mathrm{Tc}=$ Trichos trongylus colubriformis; $\mathrm{Sp}=$ Strongyloides papillosus; $\mathrm{Cc}=$ Cooperia curticei $;$ e Oc $=$ Oesopha gostomum columbianum.

Tabela adaptada de Amarante (2014).

\section{Profilaxia da verminose}

A eficiência da profilaxia é maior quando vários métodos são utilizados simultaneamente e não dependem exclusivamente da utilização de tratamentos com produtos antiparasitários. Devido à complexidade do assunto, o uso de anti-helmínticos será abordado em outro capítulo deste livro. Além dos métodos tradicionais, que já vêm sendo adotados com o objetivo de favorecer a profilaxia da verminose e que serão abordados a seguir, vale destacar que vários grupos de pesquisa vêm obtendo resultados promissores com a utilização de fitoterápicos e plantas ricas em taninos no tratamento dos animais, controle biológico com a utilização de fungos nematófagos e vacinas contra helmintos.

Os tratamentos com produtos homeopáticos, com o objetivo de auxiliar a profilaxia da verminose, têm se popularizado no Brasil. No entanto, não existem evidências científicas de que tais tratamentos sejam eficazes. Em ovinos da raça Morada Nova, avaliados 
ao longo de dezoito meses em Sobral (CE), não foi evidenciado nenhum benefício do tratamento diário com o produto homeopático "Fator Vermes" (Chagas et al., 2008). Em Botucatu (SP), também não foi possível evidenciar benefícios da utilização diária do mesmo produto em ovinos Bergamácia (Rocha et al., 2006).

\section{Seleção de animais resistentes}

A seleção de animais com maior eficiência produtiva teve como inconveniente a seleção indireta de animais com maior susceptibilidade aos parasitas (Greer, 2008), o que resultou em maior dependência na utilização de anti-helmínticos com o objetivo de controlar a verminose. Porém, devido ao aumento na prevalência de parasitas com resistência múltipla aos anti-helmíticos, a criação de animais com maior resistência contra os parasitas tem sido apontada como uma das alternativas sustentáveis de profilaxia das parasitoses. A expressão da resistência contra os parasitas é controlada geneticamente. A herdabilidade da resistência dos ovinos aos helmintos apresenta magnitude similar à de caracteres de produção, tais como ganho de peso e produção de lã, características para as quais a seleção tem sido bem-sucedida (Barger, 1989).

No Nordeste brasileiro, as estimativas de herdabilidade das contagens de OPG em ovinos Santa Inês mostraram-se extremamente variáveis. Ao longo da primeira exposição aos parasitas, a herdabilidade aumentou de 0,04 para 0,27. Na segunda exposição, a variação foi ainda mais pronunciada, de 0,01 a 0,52. Nesse estudo, observou-se que a seleção para resistência é viável e que não teria efeito adverso no crescimento de cordeiros (Lôbo et al., 2009).

Com base em estudos publicados por diversos pesquisadores, o valor médio da herdabilidade da resistência (avaliada por contagens de OPG) foi estimado em 0,27, com coeficiente de variação de $31 \pm 7 \%$ (Safari et al., 2005). Nesse mesmo estudo, as correlações genéticas e fenotípicas entre resistência e as variáveis relecionadas ao crescimento foram geralmente negativas, ou seja, favoráveis. A resistência apresentou correlação genética muito baixa com peso de 
velo e diâmetro da lã. Resultados obtidos em alguns estudos estão apresentados na Tabela 10 .

Também existem evidências animadoras demonstrando que os parasitas são incapazes de se adaptar aos ovinos selecionados para resistência. Woolaston et al. (1992) mantiveram um isolado de $H$. contortus em duas linhagens de ovinos Merino. Uma das linhagens era resistente, e a outra, susceptível à hemonchose. Os resultados demonstraram que o parasita não apresentou qualquer alteração biológica, após quatorze gerações, que permitisse sua adaptação aos hospedeiros resistentes. Trabalho posterior realizado com $H$. contortus e T. colubriformis confirmou a incapacidade dos parasitas em se adaptar aos ovinos geneticamente resistentes ou susceptíveis, o que permitiu concluir que a seleção de ovinos com base em contagens de OPG é sustentável, mesmo em longo prazo (Kemper et al., 2009).

Tabela 10 - Correlações fenotípicas* e genéticas*** entre contagem de OPG e ganho de peso $^{1}$ ou peso corporal ${ }^{2}$ em ovinos

\begin{tabular}{|c|c|c|c|c|}
\hline País & Raça & Infecção & $\begin{array}{c}\text { Coeficientes } \\
\text { de correlação }\end{array}$ & Referências \\
\hline $\begin{array}{l}\text { Nova } \\
\text { Zelândia }\end{array}$ & Romney $^{1}$ & $\begin{array}{l}\text { Várias espécies, com } \\
\text { predominância de } \\
\text { Trichostrongylus spp. }\end{array}$ & $\begin{array}{l}-0,07^{*} \\
-0,48^{*} *\end{array}$ & $\begin{array}{c}\text { Bisset et al. } \\
\text { (1992) }\end{array}$ \\
\hline Polônia & $\begin{array}{c}\text { Polish } \\
\text { Long-Wool }^{1}\end{array}$ & $\begin{array}{l}\text { O. circumcincta e } \\
\text { H. contortus }\end{array}$ & $\begin{array}{c}-0,15^{*} \\
-0,61 \text { * }\end{array}$ & $\begin{array}{c}\text { Boiux et al. } \\
(1998)\end{array}$ \\
\hline Austrália & Merino $^{2}$ & $\begin{array}{l}\text { H. contortus, } \\
\text { T. colubriformis ou } \\
\text { infecções naturais } \\
\text { mistas }\end{array}$ & $-0,20$ *** & $\begin{array}{l}\text { Eady et al. } \\
\text { (1998) }\end{array}$ \\
\hline Escócia & $\begin{array}{c}\text { Scottish } \\
\text { Blackface }^{1}\end{array}$ & O. circumcincta & $\begin{array}{l}-0,10^{*} \\
-0,27 * *\end{array}$ & $\begin{array}{c}\text { Bishop e } \\
\text { Stear (1999) }\end{array}$ \\
\hline
\end{tabular}

A seleção de animais resistentes contra uma determinada espécie de nematódeo resulta indiretamente em melhoria da resistência contra outras espécies de helmintos. Esse foi o caso de ovinos da raça Merino selecionados para resistência contra $H$. contortus, que também demonstraram, em estudos subsequentes, resistência contra T. colubriformis (Sréter et al., 1994). 
A utilização de ovinos resistentes tem demonstrado impacto favorável no que diz respeito à epidemiologia das infecções por nematódeos gastrintestinais. As elevações sazonais da carga parasitária dos ovinos resistentes são grandemente reduzidas. Como consequência, ocorre redução ainda mais acentuada da contaminação das pastagens por larvas infectantes (Barger, 1989; Bishop; Stear, 1997; 1999; Bisset et al., 1997). No Brasil, piquetes pastejados por ovelhas resistentes apresentaram 2,19 vezes menos larvas de $H$. contortus e 2,31 vezes menos larvas de T. colubriformis do que piquetes pastejados por ovelhas susceptíveis. Além de elevadas contagens de OPG, estes últimos animais apresentaram menor peso e valores mais baixos de VG (Bassetto et al., 2009).

Mesmo as raças que apresentam alta produtividade e que são consideradas susceptíveis apresentam variabilidade genética em relação à resposta imunológica contra os parasitas. Portanto, é possível incluir a resistência à verminose como um dos critérios de seleção dos animais. Esses trabalhos de seleção estão mais avançados na Austrália e na Nova Zelândia.

$\mathrm{Na}$ Austrália, no programa de melhoramento denominado LAMBPLAN, os ovinos são ranqueados de acordo com variáveis de produção relacionadas com crescimento, carcaça, lã, reprodução e resistência contra a verminose, o que permite a seleção dos animais com maior resistência (Sheep Genetics, www.sheepgenetics. org.au/). Serviço similar, denominado WormFEC, é realizado na Nova Zelândia pela Sheep Improvement Limited (SIL, www.sil. co.nz). Nesse programa, a seleção de cordeiros resistentes tem por base duas contagens de OPG. Inicialmente os cordeiros são desmamados e tratados com anti-helmíntico, em seguida são mantidos em pastagem contaminada por seis a oito semanas. Ao final desse período é realizada a primeira contagem de OPG. Os animais são novamente tratados e mantidos em pastagem contaminada por mais seis a oito semanas, quando então é realizada a segunda contagem de OPG. Outras características relacionadas à produtividade também são avaliadas. Dessa forma, a combinação das diferentes características, que incluem as contagens de OPG, permite a seleção dos animais mais resistentes e produtivos (McEwan et al., 2005). 
Uma medida bastante prática que pode ser adotada nas propriedades é a de identificar os animais com sinais clínicos de verminose, como anemia e edema submandibular, para posteriormente descartá-los do rebanho. Esses animais, além de apresentarem baixa produtividade, devido à verminose, eliminam grande quantidade de ovos de nematódeos nas fezes, sendo, portanto, grandes contaminadores da pastagem (Amarante, 2001). Caso sejam adotadas medidas similares em relação aos reprodutores a serem utilizados no rebanho, pode-se, com o decorrer do tempo, melhorar o padrão de resistência do rebanho.

\section{Principais ferramentas utilizadas para identificar os animais resistentes}

No caso da seleção de animais resistentes, como a análise é comparativa, os animais a serem analisados devem ter idade similar e ser mantidos sob as mesmas condições de manejo, expostos às infecções helmínticas. É interessante a utilização de várias ferramentas simultaneamente.

a) Exames coproparasitológicos: as contagens de OPG têm sido a principal variável utilizada nos programas de seleção para resistência a verminose. $\mathrm{O}$ ideal é que as mensurações sejam repetidas várias vezes ao longo do tempo, pois, como visto no item sobre a resposta imunológica, são inúmeros os fatores que podem ter influência na eficiência da resposta contra os parasitas. Em uma primeira avaliação, um animal jovem pode apresentar contagem elevada de OPG, porém, com o decorrer do tempo, esse mesmo indivíduo, ao desenvolver resistência, poderá apresentar redução no número de OPG. Portanto, uma análise única determinaria a eliminação precoce de um animal com potencial para desenvolver resistência. Sempre que possível, é interessante que as contagens sejam acompanhadas pela identificação dos gêneros dos nematódeos a partir de larvas infectantes produzidas em coproculturas.

b) Desempenho produtivo do animal: de nada adianta selecionar um animal resistente se ele não apresentar produtivi- 
dade satisfatória. Portanto, a principal aptidão produtiva do rebanho, lã ou carne, deve ser incluída nas avaliações.

c) Alteração na consistência das fezes (diarreia): esta última característica tem grande importância, especialmente em raças especializadas na produção de lã. Fezes diarreicas aderem à lã da região posterior do corpo do animal, o que causa prejuízo econômico devido ao descarte da lã com sujidades (Figura 38). A diarreia pode ocorrer em consequência de infecção maciça por parasitas intestinais ou, em animais hipersensíveis, pode ser consequência da ingestão contínua de larvas infectantes de vermes intestinais, mesmo que em pequena quantidade. A manutenção no rebanho de um animal com infecção pesada ou de um indivíduo hipersensível não é desejável.

Figura 38 - Fezes diarreicas aderem à lã da região posterior. A diarreia é frequente em animais com intenso parasitismo por nematódeos intestinais ou, ainda, em animais que apresentem reação de hipersensibilidade a larvas infectantes. Essas características (susceptibilidade ou hipersensibilidade) são indesejáveis, e os animais devem ser eliminados do rebanho

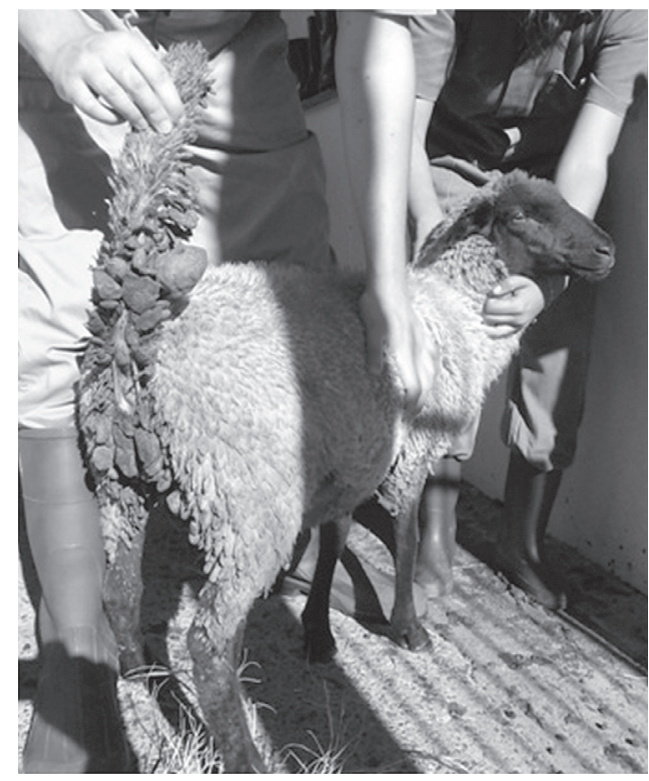


Além das variáveis citadas anteriormente, em algumas situações podem-se também associar outros parâmetros. Quando H. contortus é o parasita mais importante, pode-se determinar o valor de volume globular (micro-hematócrito). Em situações em que não seja possível a realização de micro-hematócrito, pode-se empregar o método FAMACHA. Na Nova Zelândia está sendo utilizado um kit para aferir o nível de imunoglobulinas contra os nematódeos. Um kit denominado CARLA ${ }^{\circledR}$ Saliva Test permite avaliar por ELISA o nível de IgA antiCarLA em amostras de saliva (http:// www.carlasalivatest.co.nz/). O antígeno denominado CarLA (CarLA = Carbohydrate larval antigen) está presente na superfície das larvas infectantes de todos os estrongilídeos. Anticorpos produzidos pelos ovinos contra CarLA promovem rápida eliminação das larvas infectantes. O nível de IgA antiCarLA na saliva é herdável $\left(h^{2}=0,3\right)$ e apresenta relação inversa com as contagens de OPG $(\mathrm{r}=-0,5)$. Animais com "níveis elevados" de IGA antiCarLA apresentam valores de OPG de $20 \%$ a $30 \%$ menores do que animais com títulos baixos (Shaw et al., 2012).

A inclusão da resistência contra parasitas em programas de melhoramento animal não é tarefa simples, o que explica, em parte, a razão pela qual tem sido negligenciada no Brasil. Ao contrário de características relacionadas à produção, cuja coleta de dados geralmente é mais simples, no caso de avaliações de resistência, fazem-se necessárias a colheita de amostras e a disponibilidade de laboratório e de pessoal especializado para a realização de exames. Portanto, os procedimentos são laboriosos e apresentam custos relativamente elevados.

Além disso, é imprescindível a existência de equipe multidisciplinar que conte com especialista em melhoramento animal e de parasitologista com experiência em epidemiologia e profilaxia de verminose. É também imprescindível o engajamento dos produtores rurais, que deverão estar a par do desenvolvimento do projeto e dos benefícios decorrentes da adoção do programa. 


\section{Qual a diferença entre resistência e tolerância?}

Em resposta às infecções por nematódeos gastrintestinais, os ovinos podem apresentar resistência ou tolerância (resiliência). No caso da resistência, a resposta imunológica limita o estabelecimento do parasita. No caso da tolerância, os animais são capazes de "conviver" com o parasita, com a produtividade praticamente inalterada (Albers et al., 1987). Devido às grandes perdas de sangue que ocorrem nas infecções por $H$. contortus, supõe-se que nem mesmo o mais tolerante animal seja capaz de sobreviver por muito tempo quando exposto a infecções pesadas por esse parasita. Portanto, não há dúvidas de que, nesse caso, a resistência é a característica mais importante, do ponto de vista zootécnico, pois impõe limites ao estabelecimento do parasita. Conforme afirmou Le Jambre (1995), selecionar ovinos tolerantes no caso das infecções por H. contortus seria o mesmo que selecionar animais capazes de conviver com hemorragia crônica, o que não faz sentido em produção animal. Esse mesmo princípio aplica-se às infecções por Oesophagostomum columbianum. Nesse caso, a resposta imunológica eficiente do hospedeiro, ao impedir o estabelecimento das larvas infectantes na mucosa intestinal, preveniria a formação de nódulos intestinais, os quais constituem a principal alteração patológica causada por essa espécie (Amarante et al., 2004).

Por outro lado, nas infecções causadas por alguns parasitas, tais como Trichostrongylus e Ostertagia, parte da síndrome da doença é atribuída à hipersensibilidade provocada pelas larvas infectantes. Nesse caso, os hospedeiros mais tolerantes apresentariam resposta imunológica menos intensa e seriam menos propensos a apresentar gastrenterite parasitária devido a alterações imunopatológicas (Le Jambre, 1995). O papel da resposta imunológica na redução da produtividade foi demonstrado em estudos realizados com ovinos imunossuprimidos com a aplicação de glicocorticoide (methylprednisolona). Apesar de apresentarem cargas parasitárias elevadas após infecção com T. colubriformis ou T. circumcincta, médias superiores a 70 mil e 40 mil parasitas, respectivamente, os animais não apresentaram redução considerável na performance, enquanto que 
cordeiros infectados que não foram imunossuprimidos apresentaram redução de $20 \%$ na eficiência de utilização de energia metabolizável (Greer et al., 2005; 2008). A produtividade foi afetada com maior severidade durante a fase de aquisição da imunidade, porém foi pouco afetada em animais mais velhos após o estabelecimento de resposta imunológica eficiente (idem, 2005).

Na Nova Zelândia, estudos realizados em ovinos Romney selecionados para contagens elevadas ou baixas de OPG demonstraram que o rebanho selecionado para resistência apresentou produtividade inferior à dos animais susceptíveis: os resistentes apresentaram ganho de peso inferior, menor produção de lã e maior quantidade de fezes aderida à região posterior do corpo. É importante ressaltar que os animais apresentavam-se infectados majoritariamente por T. colubriformis, T. vitrinus e O. circumcincta (Morris et al., 2000). Por outro lado, estudos recentes realizados na Austrália indicaram que a seleção para a resistência em ovinos da raça Rylington Merino não causou qualquer prejuízo na conversão alimentar e na produtividade (ganho de peso e produção de lã), em comparação com ovinos não selecionados (Liu et al., 2005).

No Brasil, como H. contortus é o principal nematódeo parasita de ovinos, sugere-se que os esforços de seleção sejam direcionados, prioritariamente, contra essa espécie e que a seleção seja direcionada para a resistência, e não para a tolerância. Além disso, é importante que a seleção para a resistência não tenha como meta apenas a redução dos valores de OPG, mas que também leve em consideração características relacionadas com a produtividade dos animais. Finalmente, os criadores e profissionais devem estar cientes de que não existe resistência absoluta. É possível que em períodos críticos, como no periparto ou em cordeiros recém-desmamados, tratamentos com anti-helmíntico ainda sejam necessários mesmo em rebanhos que foram submetidos à seleção.

\section{Os animais resistentes são mais produtivos?}

Usualmente, as raças localmente adaptadas, isto é, aquelas resistentes/tolerantes, são consideradas inferiores do ponto de vista 
da produção (produzem lã ou carcaça com qualidade inferior), enquanto que raças comerciais com elevada produtividade tendem a ser mais susceptíveis a doenças prevalentes nos trópicos. Isso induz à conclusão muitas vezes equivocada de que animais resistentes são necessariamente menos produtivos. A produtividade depende do ambiente onde os animais são mantidos, conforme demonstrado em estudo realizado no Quênia com ovinos das raças Red Maasai e Dorper (Baker et al., 2004). Nesse estudo foi demonstrada interação entre resistência e produtividade: quando os rebanhos eram mantidos em região subúmida favorável à ocorrência de haemonchose (precipitação média anual de 819 mm), os ovinos Red Maasai (resistentes) apresentaram maior produtividade. Nessas condições, os ovinos Dorper apresentaram baixo desempenho reprodutivo e elevada mortalidade. Quando as observações foram realizadas em região semiárida (precipitação média anual de $552 \mathrm{~mm}$ ), menos propícia à transmissão dos parasitas e onde os animais eram suplementados com concentrado, a produtividade das duas raças foi similar, com ligeira vantagem para os Dorpers. A diferença entre as raças explica-se pelo fato de os ovinos Red Maasai terem se adaptado ao longo de seiscentos anos a condições precárias de nutrição e elevada exposição a doenças em um sistema de produção com baixa tecnologia no Leste da África. Por sua vez, os ovinos Dorper constituem uma raça "composta" formada há pouco mais de sessenta anos na África do Sul pelo cruzamento de ovinos Dorset Horn (originalmente da Grã-Bretanha) com Black Head Persian (originalmente da Somália). Essa raça, Dorper, foi originalmente formada para ser utilizada em criações extensivas de regiões áridas da África do Sul. Portanto, não surpreende o fato de ela demonstrar problema de adaptação a condições subúmidas da África (ibidem).

Nas condições de criação de ovinos do estado de São Paulo, os resultados da interação resistência x produtividade também são grandemente influenciados pelo manejo e ambiente onde os animais são criados. Em situações de baixa exposição a larvas infectantes, como em confinamento, os animais de raças comerciais selecionados para elevada produtividade, obviamente demonstram vantagem, do 
ponto de vista produtivo. Por outro lado, quando mantidos expostos a parasitoses, rebanhos de raças locais costumam apresentar produtividade superior à de rebanhos de raças consideradas altamente produtivas, mas que são susceptíveis. Ovelhas Ile de France, por exemplo, desmamam cordeiros com maior peso do que ovelhas Santa Inês, quando os animais são mantidos confinados. Porém, o oposto ocorre quando os animais são mantidos em pastagem contaminada (Tabela 11). Quando cordeiros ou ovelhas no periparto foram infectados artificialmente com $H$. contortus, a carga parasitária dos Santa Inês foi menor, demonstrando maior resistência dessa raça. Porém, com o atendimento das necessidades nutricionais, os Ile de France mostraram-se tolerantes: as ovelhas, embora estivessem parasitadas, produziram quantidade adequada de leite, o que possibilitou desenvolvimento normal dos cordeiros (Rocha et al., 2011). Da mesma forma, cordeiros Ile de France bem alimentados apresentaram ganho em peso normal, mesmo quando infectados (Bricarello et al., 2005).

Portanto, raças com potencial produtivo elevado podem manter a produtividade normal, desde que os animais sejam mantidos em condições sanitárias e nutricionais adequadas, o que muitas vezes requer o confinamento das categorias mais susceptíveis (cordeiros e ovelhas no periparto). Um dos problemas é a viabilidade econômica desse tipo de sistema de produção. Por outro lado, em situações de campo, onde a oferta de alimento não é uniforme ao longo do ano, rebanhos de raças resistentes costumam apresentar produtividade superior à de rebanhos de raças consideradas altamente produtivas, mas que são susceptíveis.

Tabela 11 - Peso de cordeiros das raças Santa Inês e Ile de France mantidos junto com as mães do nascimento até a desmama, em pastagem ou confinamento

\begin{tabular}{c|c|c}
\hline \multirow{2}{*}{ Sistema de criação } & \multicolumn{2}{|c}{ Peso na desmama (oito semanas de idade) } \\
\cline { 2 - 3 } & Santa Inês & Ile de France \\
\hline Confinamento* & $18,2 \mathrm{~kg}$ & $22,3 \mathrm{~kg}$ \\
\hline Pastagem*** & $15,7 \mathrm{~kg}$ & $13,5 \mathrm{~kg}$ \\
\hline Diferença no peso & $\mathbf{3 , 1} \mathrm{kg}$ & $\mathbf{9 , 3} \mathrm{kg}$ \\
\hline
\end{tabular}

Fonte: *Rocha et al., 2011; **Rocha et al., 2005. 


\section{Detalhes importantes para a seleção de animais resistentes}

O ideal é que os animais sejam avaliados em condições naturais de infecção, ou seja, que os ovinos sejam mantidos em pastagem. Porém, quando a contaminação do ambiente com larvas infectantes é reduzida, pode ser necessária a infecção experimental de animais mantidos confinados. No caso de animais infectados naturalmente, é imprescindível conhecimento sobre a epidemiologia da verminose na região onde a avaliação será realizada, pois o rebanho deverá ser exposto às larvas infectantes presentes na pastagem. No estado de São Paulo, por exemplo, essas avaliações podem ser realizadas praticamente ao longo de todo o ano (vide item "Variação sazonal na contaminação da pastagem”), já que nesse estado verifica-se contaminação das pastagens com larvas infectantes em todas as estações. Certamente, o mesmo não ocorre em outras regiões do Brasil, como no Semiárido Nordestino, em que pode ocorre a interrupção na transmissão dos parasitas durante os longos períodos de estiagem (Charles, 1995). Portanto, nesses locais, as avaliações devem ser realizadas durante a estação favorável à ocorrência da verminose.

A seleção de animais resistentes geralmente baseia-se na contagem de OPG em cordeiros. Como a repetibilidade das contagens em ovinos é baixa, a seleção dos animais resistentes não deve ter como base um único exame coprológico, mas sim vários exames realizados ao longo de determinado período de tempo (Amarante et al., 1998). Porém, o Programa WormFEC, da Nova Zelândia, tem sido bem-sucedido, com apenas duas mensurações de OPG em cordeiros (vide item "Seleção de animais resistentes).

\section{Seleção assistida por marcadores}

Os estudos que envolvem genômica têm avançado consideravelmente nos últimos anos. Os trabalhos têm indicado que a resistência é poligênica, isto é, controlada por vários genes localizados em vários cromossomos (quantitative trait loci-QTL), cuja expressão sofre grande influência do ambiente. 
A descoberta de marcadores genéticos associados com a resistência não é tarefa simples. Apesar da complexidade, já se dispõe comercialmente de ferramentas para a realização de "Seleção Assistida por Marcadores”. Esse é o caso do WormSTAR ${ }^{\circledR}$, disponível na Nova Zelândia (http://www.catapultsystems.co.nz/). Os animais identificados como portadores dos genes de interesse podem apresentar redução de 7\% a 12\% nas contagens de OPG, em comparação com os animais homozigotos susceptíveis.

Um chip denominado "Ovine SNP50" que cobre 54241 SNPs (SNP = single nucleotide polymorphisms) foi lançado recentemente pela Illumina Inc. (www.illumina.com/). Na detecção e validação dos SNPs foram empregados ovinos de 85 raças, incluindo as brasileiras Morada Nova, Santa Inês e Crioula, além de outras espécies do gênero Ovis. Espera-se que esse tipo de ferramenta possa ser útil na seleção de animais portadores de várias características de importância econômica. O emprego desse chip em ovinos infectados com $H$. contortus e $T$. colubriformis indicou que existem muitos polimorfismos com pequeno efeito nas contagens de OPG, provavelmente centenas ou milhares distribuídos ao longo de todo o genoma (Kemper et al., 2011).

\section{Cruzamentos}

Os problemas com a verminose poderiam ser praticamente solucionados com a criação de ovinos de raças resistentes. Porém, um dos problemas em relação a essas raças é que elas podem apresentar características relacionadas à produtividade inferiores às de raças consideradas susceptíveis. Cordeiros da raça Santa Inês, por exemplo, produzem carcaça de qualidade inferior à de animais Suffolk ou Ile de France. Diante desse fato, o ovinocultor vê-se frente ao seguinte dilema: (1) criar uma raça adaptada às condições locais de criação e resistente aos parasitas, mesmo que ela seja menos produtiva, ou (2) criar uma raça altamente produtiva, porém pouco adaptada ao clima e aos parasitas que ocorrem nos trópicos. Uma 
terceira alternativa seria o cruzamento de uma raça susceptível, que apresente elevada produtividade, com uma raça resistente (Amarante et al., 2009).

A primeira questão que se coloca é a seguinte: qual o grau de resistência à verminose dos animais cruzados em comparação com as raças parentais? Cordeiros produto do cruzamento entre as raças Suffolk (susceptível) e Gulf Coast Native (resistente) apresentaram grau de resistência intermediário, em comparação com animais puros das duas raças (Li et al., 2001). Por sua vez, cordeiros F1 (meio Florida Native x meio Rambouillet) e Rambouillet foram mais susceptíveis a infecções artificiais por $H$. contortus do que cordeiros Florida Native (Amarante et al., 1999a). Paradoxalmente, fêmeas adultas F1 foram tão resistentes a infecções por nematódeos gastrintestinais quanto as Florida Native, enquanto as ovelhas Rambouillet mostraram-se bastante susceptíveis às infecções (idem, 1999b). Os resultados desses dois últimos estudos indicaram que os animais F1 podem apresentar elevada susceptibilidade no início da vida, mas com grande capacidade para desenvolver resistência na idade adulta.

No Brasil, resultados promissores foram observados no cruzamento de matrizes Santa Inês com reprodutores de raças ovinas de alta produtividade, tais como Ile de France, Suffolk, Texel e Dorper. Em experimento, no qual cordeiras foram submetidas a uma série de onze infecções artificiais com $H$. contortus, observou-se que, de forma geral, os animais cruzados apresentaram bons resultados, do ponto de vista parasitológico e de produção (Figura 39). Porém, dentre eles, os animais cruzados Dorper x Santa Inês sobressaíram-se ao apresentar boa produtividade e resistência bastante similar à da raça parental resistente (Silva, 2010). Em estudo com borregas naturalmente infectadas por nematódeos gastrintestinais (Figura 40), os animais oriundos de cruzamento apresentaram resistência similar à de animais puros Santa Inês. 
Figura 39 - Carga parasitária média de cordeiras Ile de France e Santa Inês e de cordeiras produto do cruzamento entre matrizes Santa Inês e reprodutores Ile de France, Dorper, Suffolk e Texel. Animais infectados artificialmente em onze ocasiões com Haemonchus contortus (Silva, 2010)

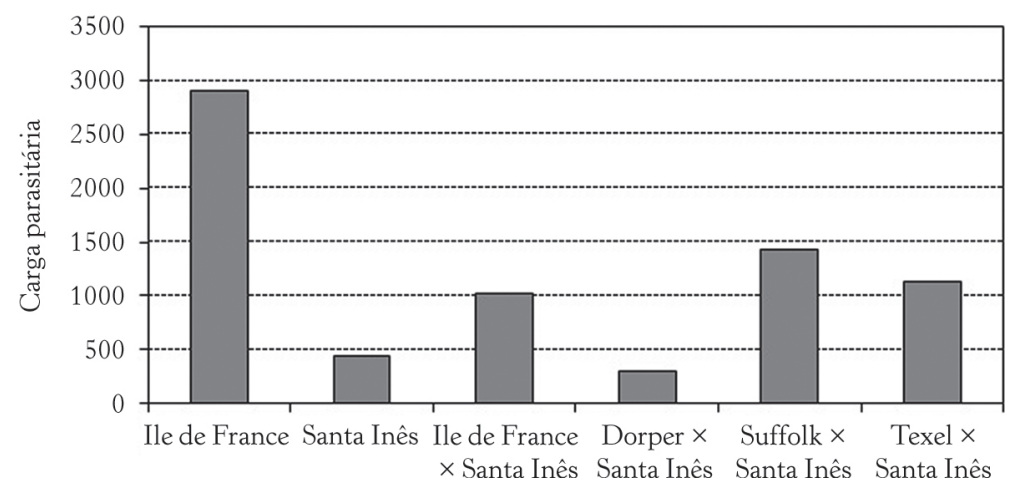

Figura 40 - Média geométrica da contagem de ovos por grama de fezes (OPG) de borregas Santa Inês (SI), Dorper x Santa Inês (DO x SI), Ile de France x Santa Inês (IF x SI), Suffolk x Santa Inês (SU x SI) e Texel x Santa Inês (TE x SI), naturalmente infectadas por nematódeos gastrintestinais

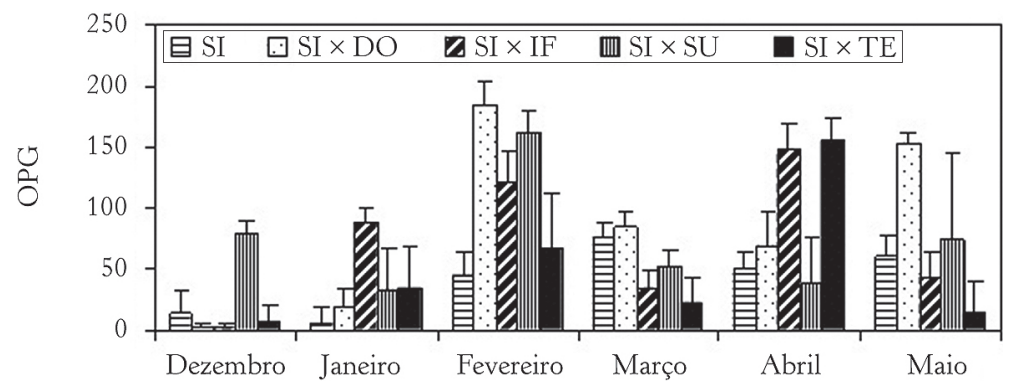

Barra $=$ desvio padrão

Fonte: Amarante et al., 2009.

Em estudo no qual foram comparados cordeiros Santa Inês com cordeiros produtos do cruzamento de ovelhas Santa Inês com carneiros Dorper, Ile de France, Hampshire Down e Texel, observou-se que os animais oriundos do cruzamento com Hampshire Down foram os que apresentaram a maior taxa de mortalidade, enquanto 
que os melhores resultados de performance, sobrevivência e qualidade da carcaça foram apresentados pelos animais cruzados com Texel (Paim et al., 2013). Portanto, no caso da produção de cordeiros destinados ao abate, o cruzamento constitui opção viável, merecendo destaque a utilização de matrizes Santa Inês, que são mais resistentes, em cruzamento com carneiros de raças com elevada produtividade, como Ile de France, Texel, Suffolk ou Dorper.

No caso de produção de lã fina, com elevado valor comercial, a utilização de uma raça resistente nem sempre é viável. Por exemplo, o cruzamento de ovinos das raças Corriedale, Merino ou Ideal (susceptíveis) com ovinos da raça Crioula Lanada (resistente) causaria prejuízo significativo à qualidade da lã, já que esta última raça produz lã com baixo valor comercial. Nesse caso, a única alternativa seria a seleção de animais resistentes dentro das raças que produzem lã com alta qualidade, conforme descrito no item "Seleção de animais resistentes".

\section{Manejo}

O controle dos nematódeos deve ter por objetivo evitar que a população de parasitas exceda níveis que comprometam a viabilidade econômica da criação. O controle parasitário usualmente é baseado quase que exclusivamente na utilização regular de anti-helmínticos. Apesar de usualmente conferir proteção contra a ocorrência de enfermidade grave e mortalidade, tais tratamentos muitas vezes são pouco eficazes, pois não previnem a exposição dos animais a níveis elevados de contaminação da pastagem por larvas infectantes. Consequentemente, reduções na produtividade ainda podem ocorrer como resultado de reinfecções no intervalo entre os tratamentos (Brunsdon, 1980). Além disso, muitas vezes os tratamentos são ineficazes devido ao sério problema da resistência anti-helmíntica.

A seguir serão apresentadas e discutidas as vantagens e desvantagens de algumas técnicas de manejo adotadas com o objetivo de limitar a infecção dos animais pelos nematódeos gastrintestinais. 


\section{Descontaminação após o descanso da pastagem}

O desenvolvimento e o tempo de sobrevivência dos estágios de vida livre dos nematódeos no ambiente sofrem influência de inúmeras variáveis, que incluem as condições climáticas e o tipo de vegetação. Portanto, o conhecimento sobre a biologia dos estágios de vida livre na pastagem pode ser útil no planejamento da profilaxia da verminose.

Em Porto Alegre (RS), observou-se que no verão ocorreu a descontaminação de pastagem que fora pastejada por ovinos, após dois meses de descanso. A redução acentuada da contaminação da pastagem, nessa época do ano, foi atribuída às temperaturas elevadas associadas aos baixos índices de precipitação e de umidade relativa do ar (Gonçalves; Vieira, 1963). Em Lages (SC), foram necessários períodos de descanso de 42 dias a 56 dias na primavera, de 70 dias a 84 dias no verão, de 112 dias a 126 dias no outono e de 98 dias a 112 dias no inverno para que ocorresse redução apreciável do número de larvas infectantes em pastagens contaminadas (Souza et al., 2000).

Portanto, a mortalidade das larvas após o descanso prolongado da pastagem pode resultar em descontaminação ambiental. Porém, essa prática, na maioria das vezes, é inviável, pois usualmente é incompatível com o manejo adequado das forrageiras, que visa aproveitar ao máximo o potencial de produção da pastagem, do ponto de vista qualitativo e quantitativo (Vendramini et al., 1999). Ao final de oitenta dias de descanso, por exemplo, a qualidade e a produtividade de uma pastagem poderão estar comprometidas. Por essa razão, várias estratégias de manejo, como o pastejo rotacionado de piquetes e o pastoreio misto ou alternado entre diferentes espécies de herbívoros, têm sido preconizadas.

\section{Sistema rotacionado de pastagens}

Em 35 criatórios de ovinos no estado de São Paulo, verificou-se que pastejo rotacionado era empregado em $80 \%$ das propriedades; $82,9 \%$ adotavam sistema semi-intensivo de produção, envolvendo o uso exclusivo de pastagem no verão e suplementação alimen- 
tar e confinamento de cordeiros durante o inverno. Em 45,7\% das propriedades, ovinos e/ou equinos compartilhavam pastagens com ovinos (Veríssimo et al., 2012).

A rotação da pastagem é uma prática que, quando bem executada, indiscutivelmente propicia aumento considerável de produtividade. $\mathrm{O}$ acesso dos animais a pastagens de boa qualidade produzidas em sistema rotacionado pode, indiretamente, resultar em benefício no combate às parasitoses, pois, como visto anteriormente, nutrição de qualidade é indispensável para o desenvolvimento adequado da resposta imunológica contra os parasitas.

A rotação é frequentemente citada como uma forma de diminuir as populações de larvas de nematódeos nas pastagens, o que, infelizmente, nem sempre ocorre. As pastagens utilizadas em esquema de rotação, geralmente, permanecem em descanso, sem animais, por períodos que variam de trinta dias a quarenta dias. Esse período de descanso, em muitas situações, é insuficiente para permitir redução significativa da contaminação da pastagem, já que os parasitas necessitam de vários dias para se desenvolver no ambiente (de ovo até larva infectante). Além disso, as larvas infectantes podem sobreviver durante várias semanas ou até mesmo vários meses no ambiente (Souza et al., 2000; Carneiro e Amarante, 2008; Rocha, 2006). Por essa razão, a rotação de pastagens, com frequência, resulta justamente no contrário do que se esperaria em termos de descontaminação. Como a rotação permite aumentar o número de animais em uma área, pode ocorrer, na verdade, aumento da contaminação.

Em Ilha Solteira (SP), observou-se ineficiência, para o controle da verminose, de um sistema rotacionado no qual os ovinos pastejavam oito piquetes, com permanência de cinco dias em cada um deles, totalizando, 36 dias de descanso de pastagem (Fernandes et al., 2004). Portanto, o benefício da rotação da pastagem sobre o controle dos parasitas é praticamente nulo em locais com clima similar ao do estado de São Paulo. Nesse caso, para que ocorresse redução significativa da contaminação da pastagem, seria necessário que os piquetes permanecessem em descanso por período 
prolongado, o que inviabilizaria o aproveitamento adequado das forrageiras.

\section{Descontaminação da pastagem pelo uso de animais resistentes ou de diferentes espécies de herbívoros}

O pastoreio envolvendo diferentes espécies de herbívoros pode ser misto ou alternado. Bons resultados no pastoreio misto podem ser obtidos quando animais susceptíveis compartilham a pastagem com animais resistentes da mesma ou de outras espécies (Barger, 1997). Já no caso do pastoreio alternado, além do efeito de "diluição", haveria a possibilidade de promover a "limpeza" de uma pastagem contaminada. Nesse caso, uma pastagem utilizada por ovinos, por exemplo, irá apresentar contaminação com nematódeos desse hospedeiro. Essa contaminação poderá ser reduzida e eventualmente eliminada algum tempo depois da retirada dos ovinos e da colocação de animais de outra espécie. A eficiência desse método depende, entre outros, da especificidade dos parasitas. As larvas de parasitas com alta especificidade parasitária são destruídas ao serem ingeridas por um animal de outra espécie. Além disso, a integração de diferentes espécies de herbívoros promove "diluição" do número de formas infectantes de um determinado parasita na pastagem. Em uma pastagem que comporta cem ovelhas, por exemplo, se forem colocados bovinos na mesma proporção, em unidade animal, tem-se que reduzir o número de pequenos ruminantes para cinquenta animais e então acrescentar os bovinos. Portanto, a contaminação da pastagem por fezes de ovinos cairá pela metade e, consequentemente, a contaminação com larvas infectantes de parasitas desses hospedeiros (Amarante, 2004). É importante ressaltar que ovinos e caprinos são parasitados pelas mesmas espécies de helmintos, o que inviabiliza o manejo integrado de ovinos e caprinos com o objetivo de descontaminar pastagens.

Em experimento realizado em Ilha Solteira, Fernandes et al. (2004) realizaram manejo rotacionado alternando bovinos adultos e ovelhas em dois módulos de pastagens. Cada módulo era constituído de oito piquetes. Os animais permaneciam em cada piquete 
por cinco dias, totalizando, portanto, quarenta dias de permanência em cada módulo. Ao final desse período (quarenta dias), as ovelhas eram transferidas para o módulo onde estavam os bovinos, e estes, por sua vez, eram transferidos para o módulo onde estavam os ovinos, e assim sucessivamente. Um grupo-controle de ovelhas foi mantido também em sistema rotacionado em outro módulo, também com oito piquetes, mas sem compartilhar a pastagem com bovinos. Os animais que compartilharam a pastagem com os bovinos apresentaram níveis de infecção inferiores e necessitaram de menor número de tratamentos com anti-helmínticos.

Em estudo realizado em Tupi Paulista (SP), observou-se que bovinos promoveram descontaminação considerável de pastagens que haviam sido previamente pastejadas por ovinos, especialmente quando as pastejaram por períodos relativamente longos, três ou seis meses. Porém, a colocação dos ovinos nos piquetes descontaminados, sem tratamento prévio com anti-helmíntico eficaz, resultou em rápida recontaminação da pastagem, o que prejudicou a eficiência da profilaxia da verminose nos ovinos utilizados no experimento, que eram da raça Ile de France, considerada susceptível a infecções parasitárias (Rocha et al., 2008). De qualquer forma, os resultados obtidos no Brasil relacionados ao manejo integrado de bovinos e ovinos, com o objetivo de descontaminar pastagens, têm se mostrado bastante promissores, especialmente quando envolvem bovinos adultos.

A integração de diferentes espécies de herbívoros pode resultar não apenas na redução da contaminação do ambiente pelas formas infectantes dos parasitas, mas também na melhora quantitativa e qualitativa das forrageiras. Na Nova Zelândia, Moss et al. (1998) observaram redução na contaminação de piquetes pastajados alternadamente por ovinos e bovinos. Curiosamente, a carga parasitária dos cordeiros que pastejaram os piquetes descontaminados foi similar à dos cordeiros que não compartilharam pastagens com bovinos. Porém, os cordeiros que pastejaram alternadamente com bovinos apresentaram produtividade mais elevada, a qual foi atribuída à 
melhora quantitativa e qualitativa das forrageiras nesse sistema de manejo (ibidem).

Na Finlândia, observou-se uma série de benefícios do pastejo misto de vacas com cria e cordeiros. Além de aumento na produção de carne por hectare, no pastejo misto os cordeiros consumiram plantas invasoras e a vegetação próxima aos bolos fecais dos bovinos, as quais não eram consumidas por esses animais. Observou-se também que os cordeiros não sofreram ataque de lobos, provavelmente devido à proteção conferida pelos bovinos (Sormunen-Cristian et al., 2012). Da mesma forma no Caribe, cordeiros e novilhas mantidos em sistema de pastoreio misto apresentaram ganho de peso superior ao de animais mantidos em pastagens separadas. Nesse caso, o aumento na produtividade foi associado não apenas à redução na taxa de infecção por $H$. contortus nos ovinos, mas também à melhora qualitativa da pastagem (Mahieu et al., 1997). $\mathrm{Na}$ Grã-Bretanha, o pastoreio de piquetes por bovinos, seguido do pastoreio por ovinos, propiciou redução na carga parasitária de cordeiros tratados periodicamente com anti-helmíntico, em comparação com cordeiros mantidos em pastoreio misto com bovinos ou em pastoreio exclusivo por ovinos (Marley et al., 2006).

\section{Especificidade parasitária e eficiência do manejo integrado entre diferentes espécies de herbívoros}

Vários fatores têm influência no sucesso de sistemas integrados de controle, os quais incluem não apenas a especificidade parasitária das diferentes espécies de nematódeos, mas também a longevidade dos estágios de vida livre no ambiente.

Quando ovinos e bovinos compartilham a mesma pastagem, infecções cruzadas podem ocorrer envolvendo algumas espécies de nematódeos (Amarante et al., 1997; Rocha et al., 2008). Porém, com o decorrer do tempo, os animais tendem a eliminar as infecções heterólogas. Estudos realizados no estado de São Paulo evidenciaram que as principais populações de parasitas em ovinos e bovinos que compartilharam pastagens são distintas (Tabela 12). 
Tabela 12 - Principais espécies de nematódeos gastrintestinais identificadas em ovinos e bovinos que compartilharam pastagens

\begin{tabular}{|c|c|c|c|c|c|}
\hline \multicolumn{2}{|c|}{ Botucatu (SP)* } & \multicolumn{2}{|c|}{ Tupi Paulista (SP) ${ }^{* *}$} & \multicolumn{2}{|c|}{ Santa Maria (RS)粎 } \\
\hline Ovinos & Bovinos & Ovinos & Bovinos & Ovinos & Bovinos \\
\hline H. contortus & H. placei & H. contortus & H. similis & H. contortus & H. placei \\
\hline \multirow[t]{3}{*}{ T. colubriformis } & axei & \multirow[t]{3}{*}{ T. colubriformis } & C. $p$ & T. axei & T. axei \\
\hline & \multirow[t]{2}{*}{ C. punctata } & & C. pectinata & T. colubriformis & C. punctata \\
\hline & & & O. radiatum & O. columbianum & O. radiatum \\
\hline
\end{tabular}

Fonte: *Amarante et al., 1997; **Rocha et al., 2008; *** Santiago et al., 1975.

Trichostrongylus axeié uma espécie que apresenta especificidade parasitária reduzida, ou seja, pode infectar várias espécies de herbívoros, inclusive equinos (Eysker et al., 1986). Portanto, em locais com elevada prevalência dessa espécie existem riscos de infecções significativas por T. axei, como no Rio Grande do Sul (Tabela 12). Em Botucatu foi avaliada a ocorrência dessa espécie em um sistema integrado de criação de ovinos e equinos. A espécie T. axei simplesmente não foi encontrada. Os principais parasitas detectados foram $H$. contortus e $T$. colubriformis nos ovinos e ciatostomíneos nos equinos. Diante disso, os autores consideraram bastante segura a utilização de equinos para descontaminar as pastagens de ovinos e vice-versa (Bagnola et al., 1996). Em estudos evolvendo bovinos e ovinos na região Oeste do estado de São Paulo, da mesma forma, a espécie T. axei não foi detectada nos ovinos (Fernandes et al., 2004; Rocha et al., 2008).

\section{Confinamento}

Animais mantidos confinados em boas condições de higiene, desde que alimentados com ração livre de contaminação, estarão menos expostos a infecções por nematódeos. Em um estudo comparativo da recria de cordeiros, evidenciou-se que os cordeiros confinados apresentaram produtividade muito superior que a de animais mantidos em pasto (Siqueira et al., 1993). Alguns ovinocultores também têm obtido bons resultados com o confinamento das ovelhas no final da gestação. As fêmeas permanecem confinadas com os cordeiros até a desmama, quando então retornam para 
a pastagem. A vantagem adicional é que os cordeiros já estariam adaptados às condições de confinamento por ocasião da desmama. O tratamento das matrizes com um anti-helmíntico eficaz, por ocasião da colocação destas no confinamento, praticamente elimina os problemas causados pela verminose.

No entanto, o confinamento dos animais resulta em aumento no custo de produção, o que muitas vezes torna essa prática inviável economicamente. Além disso, os cordeiros criados confinados tornam-se mais expostos a outros problemas sanitários, como a coccidiose. Nesse caso, faz-se necessária à adoção de medidas sanitárias para prevenir a ocorrência dessa enfermidade (vide capítulo sobre esse assunto).

\section{Referências bibliográficas}

AFRC. Energy and Protein Requirements of Ruminants. CAB International, Wallingford, UK. 1993.159 p.

ALBA-HURTADO, F. et al. Comparison of Parasitological and Productive Traits of Criollo Lambs Native to the Central Mexican Plateau and Suffolk Lambs Experimentally Infected with Haemonchus contortus. Vet. Parasitol., [s. 1.], v.172, p.277-82, 2010.

ALBERTS, G. A .A. et al. The Genetic Resistance and Resiliense to Haemonchus contortus Infection in Young Merino Sheep. Int. J. Parasitol., [s. 1.], v.17, p.1355-63, 1987.

ALMEIDA, F. A. et al. Multiple Resistance to Anthelmintics by Haemonchus contortus and Trichostrongylus colubriformis in Sheep in Brazil. Parasitol. Int., [s. 1.], v.59, p.622-5, 2010.

ALTAIF, K. I.; DARGIE, J. D. Genetic Resistance to Helminths. The Influence of Breed and Haemoglobin Type on the Response of Sheep to Primary Infections with Haemonchus contortus. Parasitology, [s. 1.], v.77, p.161-75, 1978a.

. Genetic Resistance to Helminths. The Influence of Breed and Haemoglobin Type on the Response of Sheep to Re-infection with Haemonchus contortus. Parasitology, [s. 1.], v.77, p.177-87, 1978b.

AMARANTE, A. F. T. Controle de endoparasitoses dos ovinos. In: A produção animal na visão dos brasileiros. Piracicaba: FEALQ, 2001, p.461-73. 
Controle integrado de helmintos de bovinos e ovinos. Rev. Bras. Parasitol. Vet., [s. 1.], v.13, Supl. 1, p.68-71, 2004.

. Sustainable Worm Control Practices in South America. Small Rumin. Res., [s. 1.], v.118, p.56-62, 2014.

et al. Eliminação de ovos de nematódeos gastrintestinais por ove-

lhas de quatro raças durante diferentes fases reprodutivas. Pesq. Agropec. Bras., [s. 1.], v.27, p.47-51, 1992 b.

et al. Host Specificity of Sheep and Cattle Nematodes in São Paulo State, Brazil. Vet. Parasitol., [s. 1.], v.73, p.89-104, 1997.

et al. Nematode Burdens and Cellular Responses in the Abomasal

Mucosa and Blood of Florida Native, Rambouillet and Crossbreed Lambs. Vet. Parasitol., [s. 1.], v.80, p.311-24, 1999a.

et al. Comparison of Naturally Acquired Parasite Burdens Among

Florida Native, Rambouillet and Crossbreed Ewes. Vet. Parasitol., [s. 1.], v.85, p.61-9, $1999 \mathrm{~b}$.

et al. Resistance of Santa Ines, Suffolk and Ile de France Sheep to Naturally Acquired Gastrointestinal Nematode Infections. Vet. Parasitol., [s. 1.], v.120, p.91-106, 2004.

et al. Resistance of Santa Ines and Crossbred Ewes to Naturally

Acquired Gastrointestinal Nematode Infections. Vet. Parasitol., [s. 1.], v.165, p.273-80, 2009.

; Barbosa, M. A. Seasonal Variations in Populations of Infective Larvae on Pasture and Nematode Faecal Egg Output in Sheep. Vet. Zootec., [s. 1.] v.7, p.127-33, 1995.

; PADOVANI, C. R.; BARBOSA, M. A. Contaminação da pastagem por larvas infectantes de nematódeos gastrintestinais parasitas de bovinos e ovinos em Botucatu (SP). Rev. Bras. Parasitol. Vet., [s. 1.], v.5, p.65-73, 1996.

;

Comparison between Pasture Sampling and Tracer

Lambs to Evaluate Contamination of Sheep Pastures by Nematode Infective Larvae. Rev. Bras. Parasitol. Vet., [s. 1.], v.7, p.95-9, 1998. ; GODOY, W. A. C.; BARBOSA, M. A. Nematode Egg Counts, Packed Cell Volume and Body Weight as Parameters to Identify Sheep Resistant and Susceptible to Infections by Gastrointestinal Nematodes. Ars Vet., [s. 1.], v.14, p.331-9, 1998.

; ROCHA, R. A.; BRICARELLO, P. A. Relationship of Intestinal Histology with the Resistance to Trichostrongylus colubriformis Infection in Three Breeds of Sheep. Pesqui. Vet. Bras., [s. 1.], v.27, p.43-8, 2007. 
ANDERSON, R. C.; CHABAUD, A. G.; WILLMOTT, S. Keys to the Nematode Parasites of Vertebrates. Oxfordshire: CABI International, 2009. 463p.

ANDRONICOS, N. M.; MCNALLY, J.; KOTZE, A. C.; HUNT, P. W.; AARON, I. Trichostrongylus colubriformis larvae induce necrosis and release of IL33 from intestinal epithelial cells in vitro: Implications for gastrointestinal nematode vaccine design. Int. J. Parasitol., v.42, p.295-304, 2012.

ANTHONY, R. M.; RUTITZKY, L. I.; URBAN JR., J. F.; STADECKER, M. J.; GAUSE, W. C. Protective immune mechanism in helminth infection. Nat. Rev., v.7, p.975-87, 2007.

AROSEMENA, N. A. E. et al. Seasonal Variations of Gastrointestinal Nematodes in Sheep and Goats from Semi-Arid Area in Brazil. Revue Méd. Vét., [s. 1.], v.150, p.873-6, 1999.

AUMONT, G.; GRUNER, L.; HOSTACHE, G. Comparison of the Resistance to Sympatric and Allopatric Isolates of Haemonchus contortus of Black Belly Sheep in Guadeloupe (FWI) and of INRA 401 Sheep in France. Vet. Parasitol., [s. 1.], v.116, p.139-50, 2003.

BAGNOLA JR., J.; AMARANTE, A. F. T.; MAYER, L. F. F. Verminose em equinos: exames coprológicos, contaminação da pastagem e pastejo alternado com ovinos. Vet. Zoot., [s. 1.], v.8, p.47-57, 1996.

BAHIRATHAN, M. et al. Susceptibility of Suffolk and Gulf Coast Native Suckling Lambs to Naturally Acquired Strongylate Nematode Infection. Vet. Parasitol., [s. 1.], v.65, p.259-68, 1996.

BAKER, R.L. et al. Genetic Resistance to Gastro-Intestinal Nematode Parasites in Red Maasai, Dorper and Red Maasai x Dorper Ewes in the Sub-Humid Tropics. Anim. Sci., [s. 1.], v.69, p.335-44, 1999.

et al. Genotype by Environment Interactions for Productivity and Resistance to Gastro-Intestinal Nematode Parasites in Red Maasai and Dorper sheep. Anim. Sci., [s. 1.], v.79, p.343-53, 2004.

BALIC, A.; BOWLES, V. M.; MEEUSEN, E. N. T. The immunobiology of gastrointestinal nematode infections in ruminants. Adv. Parasitol., v.45, p.181-241, 2000.

BARGER, I. A. Genetic Resistance of Hosts and its Influence on Epidemiology. Vet. Parasitol., [s. 1.], v.32, p.21-35, 1989.

. Control by Management. Vet. Parasitol., [s. 1.], v.72, p.493-506, 1997.

BASSETO, C. C. et al. Contaminação da pastagem com larvas infectantes de nematoides gastrintestinais após o pastejo de ovelhas resistentes ou 
susceptíveis à verminose. Rev. Bras. Parasitol. Vet., [s. 1.], v. 18, p.63-8, 2009.

BISHOP, S. C.; STEAR, M. J. Modeling Responses to Selection for Resistance to Gastro-Intestinal Parasites in Sheep. Anim. Sci., [s. 1.], v.64, p.469-78, 1997.

;__. Genetic and Epidemiological Relationships between

Productivity and Disease Resistance: Gastro-Intestinal Parasite Infection in Growing Lambs. Anim. Sci., [s. 1.], v.69, p.515-24, 1999.

Modeling of Host Genetics and Resistance to Infectious

Diseases: Understanding and Controlling Nematode Infections. Vet. Parasitol., [s. 1.], v.115, p.147-66, 2003.

BISSET, S. A. et al. Heritability of and Genetic Correlations Among Faecal Egg Counts and Productivity Traits in Romney Sheep. N. Z. J. Agric. Res., [s. 1.], v.35, p.51-8, 1992.

et al. Epidemiology of Nematodosis in Romney Lambs Selectively Bred for Resistance or Susceptibility to Nematode Infection. Vet. Parasitol., [s. 1.], v.70, p.255-69, 1997.

BOUIX, J. et al. Genetic Resistance to Gastrointestinal Nematode Parasites in Polish Long-Wool Sheep. Int. J. Parasitol., [s. 1.], v.28, p.1797804, 1998.

BOTREL, M. A. et al. Potencial forrageiro de gramíneas em condições de baixas temperaturas e altitude elevada. Pesq. Agropec. Bras., [s. 1.], v.37, p.393-8, 2002.

BRADLEY, R. E. Responses in Florida Native and Rambouillet Lambs Exposed to One and Two Oral Doses of Haemonchus contortus. Am. J. Vet. Res., [s. 1.], v.34, p.729-35, 1973.

BRAY, R. A.; GIBSON, D. I.; JONES, A. Keys to the Trematoda. V.3, Oxfordshire: CABI International, 2008. 824p.

BRICARELLO, P. A. et al. Response of Corriedale and Crioula Lanada Sheep to Artificial Primary Infection with Haemonchus contortus. Vet. Res. Commun., [s. 1.], v.26, p.447-57, 2002.

et al. Worm Burden and Immunological Responses in Corriedale and Crioula Lanada Sheep Following Natural Infection with Haemonchus contortus. Small Rumin. Res., [s. 1.], v.51, p.75-83, 2004. et al. Influence of Dietary Protein Supply on Resistance to Experimental Infections with Haemonchus contortus in Ile de France and Santa Ines Lambs. Vet. Parasitol., [s. 1.], v.134, p.99-109, 2005.

BRUNSDON, R. V. Principles of Helminth Control. Vet. Parasitol., [s. 1.], v.6, p.185-215, 1980. 
BUENO, M. S. et al.Infección por nematodos em razas de ovejas carnicas criadas intensivamente en la región del sudeste del Brasil. Arch. Zootec., [s. 1.], v.51, p.273-80, 2002.

CARDIA, D. F. F. et al. Immune Response and Performance of Growing Santa Ines Lambs to Artificial Trichostrongylus colubriformis Infections. Vet. Parasitol., [s. 1.], v.182, p.248-58, 2011.

CARNEIRO, R. D. C.; AMARANTE, A. F. T. Seasonal Effect of Three Pasture Plant Species on the Free-Living Stages of Haemonchus contortus. Arq. Bras. Med. Vet. Zootec., [s. 1.], v.60, p.864-72, 2008.

CHAGAS, A. C. S. et al. Anthelmintic Efficacy of Neem (Azadirachta indica A. Juss) and the Homeopathic Product Fator Vermes in Morada Nova Sheep. Vet. Parasitol., [s. 1.], v.151, p.68-73, 2008.

CHARLES, T. P. Seasonal Prevalence of Gastrointestinal Nematodes of Goats in Pernambuco State, Brazil. Vet. Parasitol., [s. 1.], v.30, p.33543, 1989.

Disponibilidade de larvas infectantes de nematódeos gastrintestinais parasitas de ovinos deslanados no semiárido pernambucano. Cienc. Rur., [s. 1.], v.25, p.437-42, 1995.

COLDITZ, I. G. et al. Some Relationship between Age, Immune Responsiveness and Resistance to Parasites in Ruminants. Int. J. Parasitol., [s. 1.], v.26, p.869-77, 1996.

COOP, R. L.; KYRIAZAKIS, I. Nutrition-Parasite Interaction. Vet. Parasitol., [s. 1.], v.84, p.187-204, 1999.

COSTA, R. L. D. et al. Performance and Nematode Infection of Ewe Lambs on Intensive Rotational Grazing with Two Different Cultivars of Panicum maximum. Trop. Anim. Health Prod., [s. 1.], v.39, p.255-63, 2007.

COURTNEY, C. H. et al. A Comparison of the Periparturient Rise in Fecal Egg Counts of Exotic and Domestic Ewes. Int. J. Parasitol., [s. 1.], v.14, p.377-81, 1984.

et al. Resistance of Exotic and Domestic Lambs to Experimental Infection with Haemonchus contortus. Int. J. Parasitol., [s. 1.], v.15, p.101-9. 1985.

DARGIE, J. D.; ALLONBY, E. W. Pathophysiology of single and challenge infections of Haemonchus contortus in Merino sheep: studies on red cell kinetics and the "self-cure" phenomenon. Int. J. Parasitol., v.5, p.147-57, 1975.

DASH, K. M. The Life Cycle of Oesophagostomum columbianum (Curtice, 1890) in Sheep. Int. J. Parasitol., [s. 1.], v. 3, p. 843-51, 1973. 
DOBSON, C.; BAWDEN, R. J. Studies on the Immunity of Sheep to Oesophagostomum columbianum: Effects of Low-Protein Diet on Resistance to Infection and Cellular Reactions in the Gut. Parasitology, [s. 1.], v.69, p.239-55, 1974.

DONALD, A. D. et al. Effects of Reproduction, Genotype and Anthelmintic Treatment of Ewes on Ostertagia spp. Populations. Int. J. Parasitol., [s. 1.], v.12, p.403-11, 1982.

EADY, S. J. et al. Resistance to Nematode Parasites in Merino Sheep: Correlation with Production Traits. Aust. J. Agric. Res., [s. 1.], v.49, p.1201-11, 1998.

ECHEVARRIA, F. et al. The Prevalence of Anthelmintic Resistance in Nematode Parasites of Sheep in Southern Latin America: Brazil. Vet. Parasitol., [s. 1.], v.62, p.199-206, 1996.

EYSKER, M.; JANSEN, J.; MIRCK, M. H. Control of Strongylosis in Horses by Alternate Grazing of Horses and Sheep and Some Others Aspects of the Epidemiology of Strongylidae Infections. Vet. Parasitol., [s. 1.], v.19, p.103-15, 1986.

FENTON, A.; RANDS, S. A. Optimal Parasite Infection Strategies: a State-Dependent Approach. Int. J. Parasitol., [s. 1.], v.34, p.813-21, 2004.

FERNANDES, L. H. et al. Efeito do pastejo rotacionado e alternado com bovinos adultos no controle da verminose em ovelhas. Arq. Bras. Med. Vet. Zoot., [s. 1.], v.56, p.733-40, 2004.

GAMBLE, H. R.; ZAJAC, A. M. Resistance of St. Croix Lambs to Haemonchus contortus in Experimentally and Naturally Acquired Infections. Vet. Parasitol., [s. 1.], v.41, p.211-25, 1992.

GAULY, M. et al. Influence of Sex on the Resistance of Sheep Lambs to an Experimental Haemonchus contortus Infection. Dtsch. Tierarztl. Wochenschr., [s. 1.], v.113, p.178-81, 2006.

GIUDICI, C. et al. Changes in Gastro-Intestinal Helminth Species Diversity in Lambs under Mixed Grazing on Irrigated Pastures in the Tropics (French West Indies). Vet. Res., [s. 1.], v.30, p.573-81, 1999.

GREER, A. W. et al. The Effect of Concurrent Corticosteroid-Induced Immuno-Suppression and Infection with the Intestinal Parasite Trichostrongylus colubriformis on Feed Intake and Utilization in Both Immunologically Naïve and Competent Sheep. Anim. Sci., [s. 1.], v.80, p.89-99, 2005.

et al.The Effect of Corticosteroid Treatment on Local Immune Responses, Intake and Performance in Lambs Infected with Teladorsagia circumcincta. Int. J. Parasitol., [s. 1.], v.38, p.1717-28, 2008. 
GONÇALVES, P. C.; VIEIRA, J. M. S. Primeira contribuição à sobrevivência de ovos e larvas de nematódeos de ovinos na pastagem, no Rio Grande do Sul. Rev. Fac. Agron. Vet., [s. 1.], v.6, p.95-103, 1963.

GONZÁLEZ, J. F. et al. Comparative Experimental Haemonchus contortus Infection of Two Sheep Breeds Native to the Canary Islands. Vet. Parasitol., [s. 1.], v.153, p.374-8, 2008.

GUIMARÃES, M. P. et al. Helmintos parasitos de ovinos da microregião de Patos de Minas - Brasil. Arq. Esc. Vet. U.F.M.G., [s. 1.], v.28, p.2179, 1976.

HORAK, I. G.; CLARK, R. The pathological physiology of helminth infestations. II. Oesophagostomum columbianum. Onderstepoort J. Vet. Res., v.33, p.139-60, 1966.

HOUDIJK, J. G. M. et al. The Relationship between Protein Nutrition, Reproductive Effort and Breakdown in Immunity to Teladorsagia circumcincta in Periparturient Ewes. Anim. Sci., v.72, p.595-606, 2001.

et al. Is the Allocation of Metabolisable Protein Prioritised to Milk Production Rather than to Immune Functions in Teladorsagia circumcincta-Infected Lactating Ewes? Int. J. Parasitol., [s. 1.], v.33, p.327-38, 2003.

INGHAM, A.; REVERTER, A.; WINDON, R.; HUNT, P.; MENZIES, M. Gastrointestinal nematode challenge induces some conserved gene expression changes in the gut mucosa of genetically resistant sheep. Int. J. Parasitol., v.38, p.431-42, 2008.

JONES, A.; BRAY, R. A.; GIBSON, D. I. Keys to the trematoda. V.2, Oxfordshire: CABI International, 2005. 745p.

KEMPER, K. E. et al. Haemonchus contortus and Trichostrongylus colubriformis did not Adapt to Long-Term Exposure to Sheep that Were Genetically Resistant or Susceptible to Nematode Infections. Int. J. Parasitol., [s. 1.], v.39, p.607-14, 2009.

et al. The Distribution of SNP Marker Effects for Faecal Worm Egg Count in Sheep, and the Feasibility of Using these Markers to Predict Genetic Merit for Resistance to Worm Infections. Genet. Res., [s. 1.], v.93, p.203-19, 2011.

KYRIAZAKIS, I.; HOUDIJK, J. Immunonutrition: Nutritional Control of Parasites. Small Rumin. Res., [s. 1.], v.62, p.79-82, 2006.

LE JAMBRE, L. F. Relationship of Blood Loss to Worm Numbers, Biomass and Egg Production in Haemonchus contortus Infected Sheep. Int. J. Parasitol., [s. 1.], v.25, p.269-73, 1995. 
LETTINI, S. E.; SUKHEDEO, V. K., 2006. Anhydrobiosis Increases Survival of Trichostrongyle Nematodes. J. Parasitol., [s. 1.], v.92, p.1002-9.

LI, Y.; MILLER, J. E.; FRANKE, D. E. Epidemiological Observations and Heterosis Analysis of Gastrointestinal Nematode Parasitism in Suffolk, Gulf Coast Native, and Crossbred Lambs. Vet. Parasitol., [s. 1.], v.98, p.273-83, 2001.

LIU, S.M. et al. Comparing Productive Performance of Nematode Resistant Merino Sheep with Non-Selected Control. Livest. Prod. Sci., [s. 1.], v.97, p.117-29, 2005.

LÔBO, R. N. B. et al. Genetic Parameters for Faecal Egg Count, Packed-Cell Volume and Body-Weight in Santa Inês Lambs. Genet. Mol. Biol., [s. 1.], v.32, n.2, p.228-94, 2009.

LOPES, C. W. G. et al. Prevalência e intensidade de infestação de helmintos gastrintestinais em Ovis aries do estado da Bahia. Pesq. Agropec. Bras., Sér. Vet., [s. 1.], v.10, p.27-9, 1975.

LOUVANDINI, H. et al. Influence of Protein Supplementation on the Resistance and Resilience on Young Hair Sheep Naturally Infected with Gastrointestinal Nematodes During Rainy and Dry Seasons. Vet. Parasitol., [s. 1.], v.137, p.103-11, 2006.

MAHIEU, M. et al. L'association d'ovins et de bovines sur prairies irriguées en Martinique. Inra Prod. Anim., [s. 1.], v.10, p.55-65, 1997.

MANSFIELD, L. S.; GAMBLE, H. R. Alveolar Mastocytosis and Eosinophilia in Lambs with Naturally Acquired Nematode Infections of Protostrongylus rufescens and Haemonchus contortus. Vet. Immunol. Imunophathol., [s. 1.], v.49, p.251-62, 1995.

MARLEY, C. L. et al. The Effect of Mixed or Sequential Grazing of Cattle and Sheep on the Faecal Egg Counts and Growth Rates of Weaned Lambs when Treated with Anthelmintics. Vet. Parasitol., [s. 1.], v.142, p.134-41, 2006.

MARQUARDT, W. H.; DEMAREE, R. S.; GRIEVE, R. B. Parasitology and Vector Biology. 2.ed. Academic Press, 2000.

MATIKA, O. et al. Resistance of Sabi and Dorper Ewes to Gastro-Intestinal Nematode Infections in an African Semi-Arid Environment. Small Rumin. Res., [s. 1.], v.47, p.95-102, 2003.

MCEWAN, J. C. et al. Breeding for Host Resistance to Nematodes in New Zealand: WormFEC. In: INTERNATIONAL CONFERENCE OF THE WORLD ASSOCIATION FOR THE ADVANCEMENT 
OF VETERINARY PARASITOLOGY, 20, 2005, Christchurch. Proceedings... Christchurch: WAAVP, 2005, p. 171.

MCMANUS, C. et al. Genetic Factors of Sheep Affecting Gastrointestinal Parasite Infections in the Distrito Federal, Brazil. Vet. Parasitol., [s. 1.], v.166, p.308-13, 2009.

MEXIA, A. A. et al. Susceptibilidade a nematoides em ovelhas Santa Inês, Bergamácia e Texel no Noroeste do Paraná. Semina: Ciências Agrárias, [s. 1.], v.32, supl. 1, p.1921-1928, 2011.

MILLER, J. E. et al. Epidemiology of Gastrointestinal Nematode Parasitism in Suffolk and Gulf Coast Native Susceptibility to Haemonchus contortus Infection. Vet. Parasitol., [s. 1.], v.74, p.55-74, 1998.

MORAES, F. R. et al. Susceptibilidade de ovinos das raças Suffolk e Santa Inês à infecção natural por tricostrongilídeos. Arch. Vet. Sci., [s. 1.], v.6, p.63-9, 2000.

MORRIS, C. A. et al. Continued Selection of Romney Sheep for Resistance or Susceptibility to Nematode Infection: Estimates of Direct and Correlated Responses. Anim. Sci., [s. 1.], v.70, p.17-27, 2000.

MOSS, R. A. et al. Effect of Cattle Grazing Strategies and Pasture Species on Internal Parasites of Sheep. New Zeal. J. Agric. Res., [s. 1.], v.41, p.533-44, 1998.

MUGAMBI, J. M. et al. Response of Dorper and Red Maasai Lambs to Trickle Haemonchus contortus Infections. Res. Vet. Sci., [s. 1.], v.61, p.218-21, 1996.

et al. Resistance of Four Sheep Breeds to Natural and Subsequent Artificial Haemonchus contortus Infection. Vet. Parasitol., [s. 1.], v.69, p.265-73, 1997.

NIEZEN, J. H. et al. Effect of Plant Species on the Larvae of Gastrointestinal Nematodes which Parasitise Sheep. Int. J. Parasitol., [s. 1.], v.28, p.791-803, 1998.

OLIVEIRA, A. L. F. et al. Effect of Plant Trichomes on the Vertical Migration of Haemonchus contortus Infective Larvae on Five Tropical Forages. Trop. Anim. Health Prod. [s. 1.], v.41, p.775-82, 2008.

O'SUlLIVAN, B. M.; DONALD, A. D. A Field Study of Nematode Parasite Populations in the Lactating Ewe. Parasitology, [s. 1.], v.61, p.3301-315, 1970.

PAIM, T. P. et al. Performance, Survivability and Carcass Traits of Crossbred Lambs from Five Paternal Breeds with Local Hair Breed Santa Inês Ewes. Small Rumin. Res., [s. 1.], v.112, p.28-34, 2013. 
PRESTON, J. M.; ALLONBY, E. W. The Influence of Breed on the Susceptibility of Sheep to Haemonchus contortus Infection in Kenya. Res. Vet. Sci., [s. 1.], v.26, p.134-9, 1979.

RADHAKRISHNAN, C. V.; BRADLEY, R. E.; LOGGINS, P. E. Host Responses of Worm Free Florida Native and Rambouillet Experimentally Infected with Haemonchus contortus. Am. J. Vet. Res., [s. 1.], v.33, p.817-23, 1972.

RAMOS, C. I. et al. Epidemiologia das helmintoses gastrintestinais de ovinos no Planalto Catarinense. Ciênc. Rural, [s. 1.], v.34, p.1889-95, 2004.

ROCHA, R. A. Sobrevivência e migração vertical de larvas infectantes de Trichostrongylus colubriformis em gramíneas, nas diferentes estações do ano. 2006. $110 \mathrm{f}$. Tese (Doutorado) - Faculdade de Medicina Veterinária e Zootecnia, Universidade Estadual Paulista, Botucatu, 2006.

; AMARANTE, A. F. T.; BRICARELLO, P. A. Comparison of the Susceptibility of Sata Inês and Ile de France Ewes to Nematode Parasitism Around Parturition and During Lactation. Small Rumin. Res., [s. 1.], v.55, p.65-75, 2004.

. Resistance of Santa Inês and Ile de France Suckling Lambs to Gastrointestinal Nematode Infections. Rev. Bras. Parasitol. Vet., [s. 1.], v.14, p.17-20, 2005.

; PACHECO, R. D. L.; AMARANTE, A. F. T. Efficacy of Homeopathic Treatment Against Natural Infection of Sheep by Gastrointestinal Nematodes. Rev. Bras. Parasitol. Vet., [s. 1.], v.15, p.23-7, 2006.

et al. Sheep and Cattle Grazing Alternately: Nematode Parasitism and Pasture Decontamination. Small Rumin. Res., [s. 1.], v.75, p.13543, 2008a.

et al. Recuperação de larvas infectantes de Trichostrongylus colubriformis em três espécies de gramíneas contaminadas no verão. Rev. Bras. Parasitol. Vet., [s. 1.], v.17, p.227-34, 2008b.

et al. Influence of Protein Supplementation During Late Pregnancy and Lactation on the Resistance of Santa Ines and Ile de France Ewes to Haemonchus contortus. Vet. Parasitol., [s. 1.], v.181, p.229-38, 2011.

SADDIQI, H. A. et al. Small Ruminant Resistance Against Gastrointestinal Nematodes: a case of Haemonchus contortus. Parasitol. Res., [s. 1.], v.109, p.1483-500, 2011.

SAFARI, E.; FOGARTY, N. M.; GILMOUR, A. R. A Review of Genetic Parameter Estimates for Wool, Growth, Meat and Reproduction Traits in Sheep. Livest. Prod. Sci., [s. 1.], v.92, p.271-89, 2005. 
SANTIAGO, M. A. M.; BENEVENGA, S. F.; COSTA, U. C. Epidemiologia e controle da helmintose ovina no município de Itaqui, Rio Grande do Sul. Pesq. Agropec. Bras., Sér. Vet., [s. 1.], v.11, p.1-7, 1976. ; COSTA, U. C.; BENEVENGA, S. F. Estudo comparativo da prevalência de helmintos em ovinos e bovinos criados na mesma pastagem. Pesq. Agropec. Bras., [s. 1.], v.10, p.51-6, 1975.

SANTOS, E. D. G. et al. Avaliação de pastagem diferida de Brachiaria decumbens Stapf: 1. características químico-bromatológicas da forragem durante a seca. Rev. Bras. Zootec., [s. 1.], v.33, n.1, p.203-13, 2004.

SANTOS, M. C.; SILVA, B. F.; AMARANTE, A. F. T. Environmental Factors Influencing the Transmission of Haemonchus contortus. Vet. Parasitol., [s. 1.], v.188, p.277-84, 2012.

SCHMIDT, G. D. Handbook of Tapeworm Identification. Boca Raton: CRC Press, Inc., 1986. 675p.

SCIACCA, J. et al. Vertical Migration by the Infective Larvae of Three Species of Parasitic Nematodes: is the Behaviour Really a Response to Gravity? Parasitology, [s. 1.], v.125, p.553-60, 2002.

SCZESNY-MORAES, E. A. et al. Resistência anti-helmíntica de nematoides gastrintestinais em ovinos, Mato Grosso do Sul. Pesq. Vet. Bras., [s. 1.], v.30, p.229-36, 2010.

SHAW, R. et al. Salivary IgA: A Suitable Measure of Immunity to Gastrointestinal Nematodes in Sheep. Vet. Parasitol., [s. 1.], v.186, p.109-17, 2012.

SILVA, B. F. et al. Vertical Migration of Haemonchus contortus Third Stage Larvae on Brachiaria decumbens Grass. Vet. Parasitol., [s. 1.], v.158, p.85-92, 2008.

SILVA, J. B.; FONSECA, A. H. Susceptibilidade racial de ovinos a helmintos gastrintestinais. Semina Ciênc. Agrar., v.32, supl. 1, p.1935-42, 2011.

SILVA, M. B. Resistência às infecções artificiais por Haemonchus contortus de cordeiras Santa Inês, Ile de France e de cordeiras productos do cruzamento entre a raça Santa Inês e as raças Dorper, Ile de France, Suffolk e Texel. 2010, 97f. Dissertação (Mestrado em Biologia Geral e Aplicada) - UNESP.

SIQUEIRA, E. R.; AMARANTE, A. F. T.; FERNANDES, S. Estudo comparativo da recria de cordeiros em confinamento e pastagem. Vet. Zoot., [s. 1.], v.5, p.17-28, 1993.

SORMUNEN-CRISTIAN, R.; MANNINEN, M.; OKSANEN, A. Mixed Grazing by Suckler Cows, Calves and Lambs in a Cultivated Pasture. Livest. Sci., [s. 1.], v.145, p.258-65, 2012. 
SOUZA, P. et al. Período para desinfestação das pastagens por larvas de nematoides gastrintestinais de ovinos em condições naturais nos campos de Lages (SC). Rev. Bras. Parasitol. Vet., [s. 1.], v.9, p.159-64, 2000.

SOUZA, M. F. et al. Gastrointestinal Parasites of Sheep, Municipality of Lajes, Rio Grande do Norte, Brazil. Rev. Bras. Parasitol. Vet., [s. 1.], v.21, p.71-3, 2012.

SRÉTER, T.; KASSAI, T.; TAKÁCS, E. The Heritability and Specificity of Responsiveness to Infection with Haemonchus contortus in Sheep. Int. J. Parasitol., [s. 1.], v.24, p.871-6, 1994.

STEAR, M. J.; MURRAY, M. Genetic Resistance to Parasitic Disease: Particularly of Resistance in Ruminants to Gastrointestinal Nematodes. Vet. Parasitol., [s. 1.], v.54, p.161-76, 1994.

TEREFE, G. et al. Immune Response to Haemonchus contortus Infection in Susceptible (INRA 401) and Resistant (Barbados Black Belly) Breeds of Lambs. Parasite Immunol., [s. 1.], v.29, p.415-24, 2007.

VALDERRÁBANO, J.; GOMEZ-RINCÓN, C.; URIARTE, J. Effect of Nutricional Status and Fat Reserves on the Periparturient Immune Response to Haemonchus contortus Infection in Sheep. Vet. Parasitol., [s. 1.], v.141, p.122-31, 2006.

VAN DIJK, J. et al. Ultraviolet Light Increases Mortality of Nematode Larvae and Can Explain Patterns of Larval Availability at Pasture. Int. J. Parasitol., [s. 1.], v.39, p.1-1156, 2009.

VASCONCELOS, O. T. et al. Parâmetros parasitológicos coprométricos e necroscópicos em ovinos do município de Catanduva, estado de São Paulo. Ars Vet., [s. 1.], v.1, p.89-101, 1985.

VENDRAMINI, J. M. B. et al. Matéria seca, digestibilidade in vitro e composição químico-bromatológica do capim (Paspalum notatum) cv. 'tifton 9' com diferentes idades. Sci. Agric., [s. 1.], v.56, p.637-44, 1999.

VERÍSSIMO, C. J. et al. Multidrug and Multispecies Resistance in Sheep Flocks from São Paulo State, Brazil. Vet. Parasitol., [s. 1.], v.187, p.20916, 2012.

VIEIRA, M. I. B.; GONÇALVES, P. C.; PINHEIRO, A. C. Prevalência, intensidade média da infecção e carga patogênica de gêneros e espécies de nematódeos gastrintestinais de cordeiros da região de Bagé, RS. Hora Vet., [s. 1.], n.48, p.28-32, 1989.

WANYANGU, S. W. et al. Response to Artificial and Subsequent Natural Infection with Haemonchus contortus in Red Maasai and Dorper Ewes. Vet. Parasitol., [s. 1.], v.69, p.275-82, 1997. 
WOOD, I. B. et al. World Association for the Advancement of Veterinary Parasitology (W.A.A.V.P.) Second Edition of Guidelines for Evaluating the Efficacy of Anthelmintics in Ruminants (Bovine, Ovine, Caprine). Vet. Parasitol., [s. 1.], v.58, p.181-213, 1995.

WOOLASTON, R. R.; ELWIN, R. L.; BARGER, I. A. No Adaptation of Haemonchus contortus to Genetically Resistant Sheep. Int. J. Parasitol., [s. 1.], v.22, p.377-80, 1992.

YAZWINSKI, T. A. et al. Parasite Resistance in Straightbred and Crossbred Barbados Blackbelly Sheep. J. Anim. Sci., [s. 1.], v.49, p.919-26, 1979.

ZAJAC, A. M.; HERD, R. P.; MCCLURE, K. E. Trichostrongylid Parasite Populations in Pregnant or Lactating and Unmated Florida Native and Dorset/Rambouillet Ewes. Int. J. Parasitol., [s. 1.], v.18, p.981-5, 1988. 


\section{2 \\ Classe trematoda}

No Brasil, três gêneros de trematódeos foram registrados em ovinos: Paramphistomum, parasita do rumem; Eurytrema (Figura 41), parasita de canais pancreáticos; e Fasciola, parasita do fígado. Os trematódeos parasitas de ruminantes são hermafroditas e apresentam hospedeiro intermediário invertebrado em seu ciclo de vida. Prejuízos significativos têm sido registrados devido ao parasitismo por Fasciola hepatica, causador da enfermidade denominada fasciolose, a qual será abordada detalhadamente a seguir.

Figura 41 - Eurytrema spp.

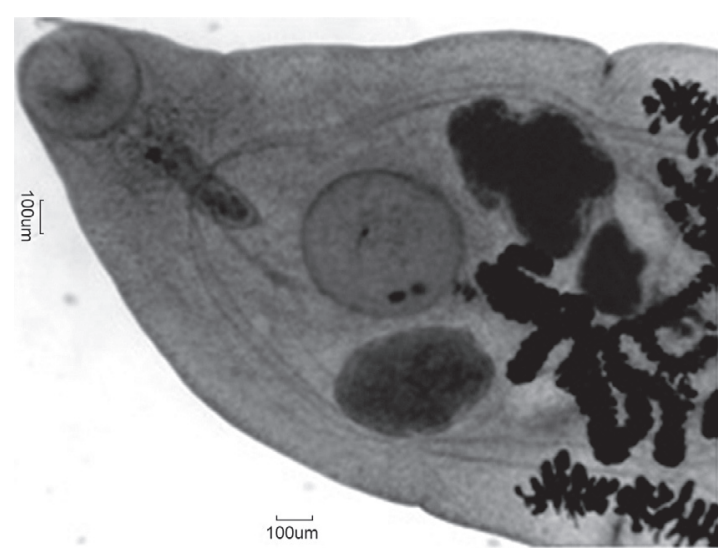




\section{Fasciola hepatica}

Fasciola hepatica é um trematódeo que no estágio adulto parasita os ductos biliares de ovinos, bovinos e outros mamíferos, incluindo animais silvestres. As formas imaturas de F. hepatica são encontradas no parênquima hepático. No estágio adulto, $F$. hepatica apresenta formato de folha com $2 \mathrm{~cm}$ a $3,5 \mathrm{~cm}$ de comprimento por $1 \mathrm{~cm}$ de largura (Figura 42). O tegumento é coberto por espinhos microscópicos que se projetam em direção posterior.

Figura 42 - Exemplares de Fasciola hepatica obtidos do fígado de um ovino

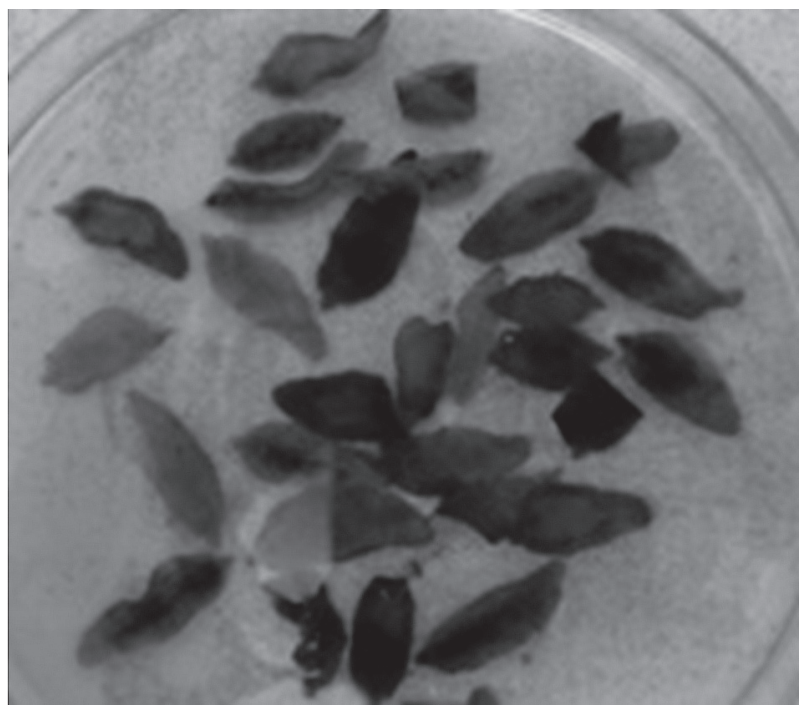

A presença de F. hepatica depende de condições ambientais adequadas, primariamente umidade e temperatura, que favoreçam a existência dos moluscos do gênero Lymnaea que atuam como hospedeiros intermediários. A fasciolose é causa de perda econômica significativa na pecuária devido à redução na taxa de crescimento, redução na produção de leite, efeitos adversos na quantidade e qualidade da lã e interferência nos parâmetros reprodutivos. Perdas diretas devido à mortalidade e a condenação de fígados são signifi- 
cativas, porém, a ocorrência de quadros subclínicos torna as perdas difíceis de serem quantificadas. Além disso, a fasciolose é uma enfermidade emergente em humanos (Rojo-Vázquez et al., 2012).

\section{Ciclo evolutivo ${ }^{1}$}

Os parasitas adultos são hermafroditas e reproduzem-se sexuadamente dentro do hospedeiro definitivo, onde podem viver por oito a onze anos. Cada parasita adulto pode produzir de 2 mil a 2.500 ovos por dia, os quais são excretados via bile nas fezes do hospedeiro. Os ovos são produzidos ao longo de todo o ano, porém, verifica-se variação sazonal na eliminação de ovos, que aumenta na primavera e outono.

Os ovos eliminados completam o desenvolvimento no ambiente com a formação de uma larva ciliada, denominada miracídio. Para o desenvolvimento, os ovos devem se separar da massa fecal e necessitam de temperatura e umidade adequadas. No laboratório, em temperatura de $26^{\circ} \mathrm{C}$, o processo completa-se em doze dias, porém, no ambiente, várias semanas podem ser necessárias (até dois meses, em temperatura de $10^{\circ} \mathrm{C}$ a $12^{\circ} \mathrm{C}$ ). A luz induz o miracídio a produzir uma enzima proteolítica que causa a ruptura da casca do ovo na região do opérculo, por onde ele emerge. Imediatamente após a eclosão, o miracídio, que é móvel, procura pelo molusco, hospedeiro intermediário, e na busca, estímulos quimiotáticos que envolvem temperatura, $\mathrm{pH}$, oxigênio, composição iônica e turbidez da água são fatores decisivos. O miracídio penetra ativamente no molusco, onde se multiplica assexuadamente, dando origem sucessivamente a esporocistos, redias e cercárias. O número de cercárias formadas é bastante variável e depende do número de miracídios que infectaram o molusco, variando de 10 a 4 mil cercárias (média: 100 cercárias/Lymnaea). Em condições naturais, o desenvolvimento no interior do molusco leva de oito a dez semanas. As cercárias abandonam o molusco, nadam livremente e, após

1 De acordo com as descrições de Rojo-Vázquez et al. (2012). 
perderam a cauda, encistam-se aderidas às plantas subaquáticas, dando origem às metacercárias. Porém, aproximadamente $10 \%$ das cercárias se encistam na água sem se aderirem à vegetação. As metacercárias podem sobreviver ao longo do inverno, por outro lado, temperatura elevada e dessecação são prejudiciais à sobrevivência.

Os animais infectam-se durante o pastejo, porém, animais confinados também podem infectar-se ao consumir água ou feno contaminado. A metacercária perde sua membrana cística no intestino delgado, e as formas imaturas penetram na parede intestinal, migram pela cavidade peritonial, até encontrarem o fígado. Aproximadamente quatro dias após a infecção, as formas imaturas começam a perfurar a cápsula de Glisson. Nesta fase, elas apresentam formato lanceolado e medem de $1 \mathrm{~mm}$ a $2 \mathrm{~mm}$. Elas migram pelo parênquima hepático e a partir de quarenta dias após a infecção começam a estabelecer-se nos ductos biliares, seu destino final, onde atingem a maturidade sexual. Os primeiros ovos são detectados nas fezes entre 55 e 56 dias após a infecção. Nem todas as metacercárias ingeridas dão origem a parasitas adultos no fígado: muitas são eliminadas nas fezes ou destruídas durante a migração no corpo do animal. Localizações erráticas dos parasitas, como nos pulmões, podem ocorrer e resultam no encapsulamento dos parasitas. O estabelecimento varia de $25 \%$ a $60 \%$, com média de $40 \%$. A infectividade das metacercárias é influenciada pela temperatura ambiental durante o desenvolvimento dentro do molusco e pelas condições climáticas após a formação da metacercária. A temperatura ideal situa-se entre $22^{\circ} \mathrm{C}$ e $23^{\circ} \mathrm{C}$.

\section{Patogenia e sinais clínicos da fasciolose}

Os danos causados pelo parasita devem-se a fatores mecânicos, químicos e à resposta imune e inflamatória do hospedeiro. Os danos mecânicos estão associados à migração das formas imaturas pelo parênquima hepático e são causados pelos espinhos do tegumento e pelas enzimas proteolíticas secretadas pelos parasitas. Alguns produtos químicos, como as catepsinas, também desempenham um 
importante papel na patogenia da infecção. A infecção é associada com uma forte resposta do tipo Th2, a qual esta relacionada com a produção de citocinas que contribuem para a ocorrência de alterações fisiopatológicas. Nos ductos biliares, os parasitas adultos induzem colangite, hiperplasia do epitélio e fibrose. A severidade da infecção pode ser reduzida em animais com infecções prévias, os quais apresentam eosinofilia precoce e infiltração de linfócitos no fígado, o que causa redução no tamanho dos helmintos e depressão na produção de ovos (ibidem).

A patogenia da infecção varia em função do número de metacercárias ingeridas e da fase de desenvolvimento do parasita no fígado. A patogenia pode ser dividida em duas fases. A primeira fase corresponde aos danos causados pelas formas imaturas no parênquima hepático, e a segunda fase corresponde à presença dos vermes adultos na luz dos ductos biliares (Figura 43), onde os espinhos de seu tegumento provocam irritação e inflamação (colangite). Nos ovinos, a fasciolose pode ser aguda, subaguda ou crônica (Taylor et al., 2007):

- Fasciolose aguda: é a forma mais grave e a menos comum. Ocorre de duas a seis semanas após a ingestão de grande quantidade de metacercárias, usualmente acima de duas mil, e é devida à extensa destruição do parênquima hepático e a severa hemorragia causada pelos trematódeos jovens durante sua migração pelos tecidos do fígado.

- Fasciolose subaguda: essa forma da enfermidade ocorre de seis a dez semanas após a ingestão de quinhentas a mil metacercárias. Neste caso, as metacercárias são ingeridas ao longo de um período maior de tempo, e, enquanto algumas chegam aos ductos biliares, onde causam colangite, outras estão ainda migrando pelo parênquima hepático, onde causam lesões menos severas, porém similares àquelas que ocorrem na enfermidade aguda. Os animais apresentam anemia e hipoalbuminemia severas, que podem resultar em taxas elevadas de mortalidade. Os ovinos acometidos podem apre- 
sentar-se anêmicos, com edema submandibular e ascite. Os sinais clínicos podem persistir por uma ou duas semanas antes da morte do animal.

- Fasciolose crônica: é a forma mais comum da enfermidade. Ocorre de quatro a cinco meses após a ingestão de número moderado de metacercárias, de duzentas a quinhentas. Cada trematódeo pode causar perda diária de mais de 0,5 $\mathrm{ml}$ de sangue. Em consequência, os animais apresentam anemia e hipoalbuminemia. Ocorre redução do apetite e perda progressiva da condição corporal. Os animais apresentam-se anêmicos e edemaciados.

Figura 43 - Aspecto do fígado de um ovino com fasciolose crônica

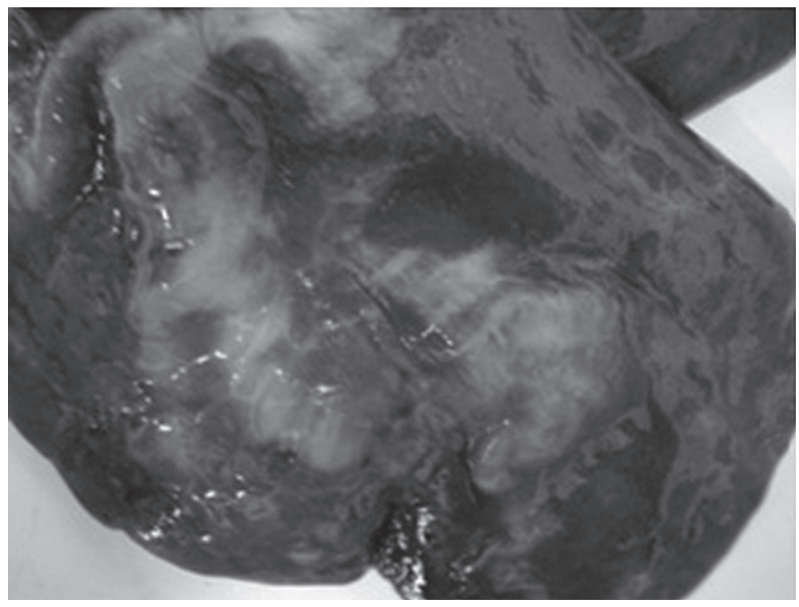

\section{Epidemiologia da fasciolose no Brasil}

Existem evidências de que a incidência da fasciolose tem crescido devido, provavelmente, a mudanças climáticas e ao aumento no comércio de animais. A ocorrência de fasciolose em uma região depende de uma fonte de infecção (animal parasitado), de condições ambientais que permitam o desenvolvimento dos ovos e da presença do molusco Lymnaea spp., hospedeiro intermediário do 
parasita. Esses moluscos vivem em locais alagadiços, como brejos, e em locais sujeitos a inundações periódicas. Em algumas regiões de vale, a infecção com o parasita pode ocorrer ao longo de todo o ano (Figura 44).

Figura 44 - Locais planos e alagadiços favorecem a ocorrência da fasciolose

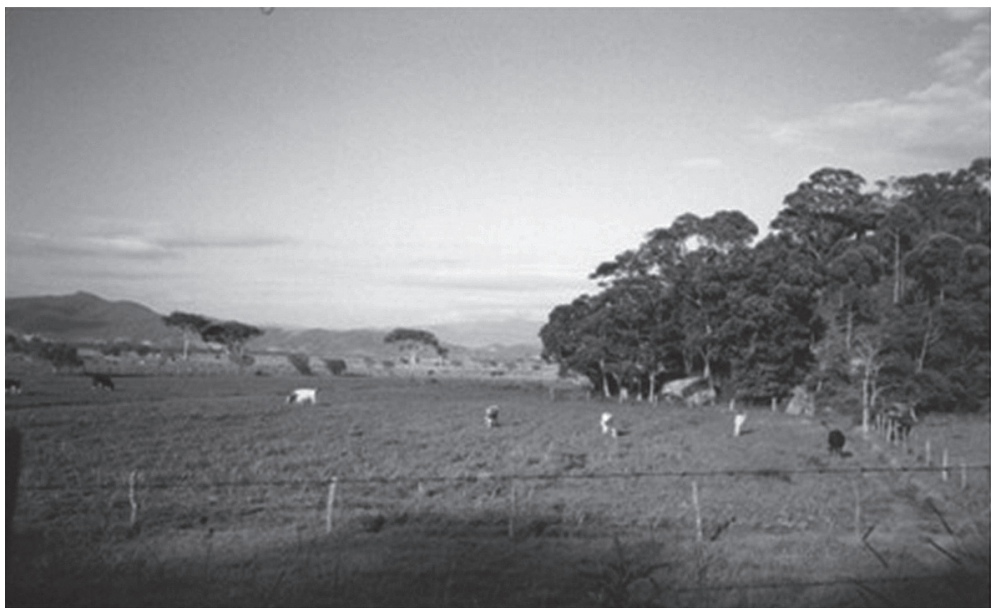

No Brasil, áreas com elevada prevalência de F. hepatica estão localizadas no Rio Grande do Sul, em Santa Catarina (Vale do Itajaí), no Paraná, em São Paulo (Vale do Paraíba e Vale do Ribeira), no sul de Minas Gerais, no Rio de Janeiro e no Espírito Santo. No Rio Grande do Sul, a condenação de fígados por fasciolose em abatedouros vem apresentando aumento. No início da década de 1960, os índices eram de 8\%, e aumentaram para 11,5\% entre 1974 e 1977 , chegando a 14,7\% em 1984 (Echevarria, 2004).

No vale do rio Paraíba, estado de São Paulo, Lymnaea columella é o hospedeiro intermediário de F. hepatica (Ueta, 1980; Amato et al., 1986). Sua densidade populacional apresenta declínio cíclico entre setembro e fevereiro e aumenta de março a setembro, com redução acentuada na população de moluscos em períodos de estiagem. Resultados obtidos com ovinos traçadores indicaram que o maior número de metacercárias está presente na pastagem entre 
junho e outubro e entre março e abril, porém existe risco de infecção durante a maior parte do ano. As precipitações elevadas no verão permitem a sobrevivência de metacercárias, apesar das elevadas temperaturas registradas no período (Amato et al., 1986).

No município de Piquete, a densidade populacional de L. columella apresenta relação inversa com a temperatura e a pluviosidade: maior número de moluscos é encontrado no período seco do ano (maio-outubro). Já no município de Redenção da Serra, o maior número de moluscos ocorreu de janeiro a março, período com precipitações e temperaturas elevadas (Maure et al., 1998).

Além das regiões do estado de São Paulo citadas anteriormente, existem também relatos de fasciolose em outros municípios. Durante o período de outubro de 2008 a setembro de 2009, a partir do registro da condenação de fígado de bovinos em matadouro, observou-se que, do total de 7.051 bovinos abatidos, 5\% estavam infectados por F. hepatica. Os bovinos parasitados eram majoritariamente procedentes de Tuiuti, Bragança Paulista, Piracaia, Santo Antônio de Posse e Amparo. Outros cinco municípios - Monte Alegre do Sul, Jaguariúna, Joanópolis, Pedreira e Socorro - forneceram menor número de animais para abate e de forma intermitente, com percentual de animais parasitados que variou entre $0,34 \% \mathrm{e}$ 7,14\% (Boas Filho et al., 2010). A presença de F. hepatica também foi registrada em uma propriedade em Presidente Prudente (Tostes et al., 2004) e em outra no município de Porangaba (SP), na qual um surto de fasciolose resultou na morte de vários bovinos da raça Nelore (Schmidt et al., 2010). Esses estudos evidenciaram, pela primeira vez, a presença de fasciolose em várias regiões do estado de São Paulo, indicando a necessidade de diagnóstico adequado e de adoção de medidas de profilaxia da parasitose.

No Rio Grande do Sul, a Fasciolose é importante causa de perda econômica na pecuária, especialmente na região de fronteira com o Uruguai. O problema agravou-se com a construção de canais de irrigação que utilizam a água da Lagoa Mangueira e Mirim, sendo comuns surtos de fasciolose aguda em rebanhos ovinos. Na região de planície encontrada na fronteira com o Uruguai, taxa elevada 
de mortalidade de ovinos, que pode atingir de $15 \%$ a 20\%, devido à fasciolose aguda, ocorre especialmente durante os invernos chuvosos. As espécies Lymnaea viatrix e L. columella estão distribuídas no estado e atuam com hospedeiro intermediário de F. hepatica (Ueno et al., 1982). A fasciolose é também muito comum em locais onde plantações irrigadas, como as de arroz, são periodicamente utilizadas para a colocação de animais. Recentemente, oito surtos de fasciolose aguda e subaguda foram descritos em ovinos criados em Santa Vitória do Palmar, em áreas utilizadas no plantio de arroz irrigado. Dois surtos ocorreram em julho e agosto, e seis ocorreram na primavera e no início do verão. A morbidade variou de 3\% a 66,7 $\%$, e a mortalidade variou de 3\% a $50 \%$ (Fiss et al., 2013).

\section{Diagnóstico}

Existem vários métodos que podem ser utilizados no diagnóstico parasitológico de F. hepatica, os quais estão descritos detalhadamente no manual de Ueno e Gonçalves (1998). Dentre os métodos, destaca-se, pela rapidez e facilidade de execução, a técnica de "quatro tamises metálicos", que consiste na lavagem das fezes por tamises com malhas de $174 \mu \mathrm{m}, 96 \mu \mathrm{m}, 87 \mu \mathrm{m}$ e $65 \mu \mathrm{m}$. Neste último tamis, os ovos são retidos e depois transferidos para uma placa de Petri, onde são quantificados em estereomicroscópio. Métodos de flutuação, com a utilização de solução com alta densidade, como sulfato de zinco (1,350), podem ser empregados, porém, causam o colapso do ovo, e o que se observa microscopicamente é a casca deste. Isso ocorre quando se utiliza o método Flotac ${ }^{\circledR}$. Contagens de cem a duzentos ovos por grama (OPG) indicam infecção severa e sugerem a necessidade de tratamento com fasciolicida (Rojo-Vázquez et al., 2012).

\section{Profilaxia e tratamento}

Nas regiões de ocorrência de F. hepatica, o controleé baseado geralmente apenas no tratamento dos animais. Na maioria das vezes, 
é praticamente impossível eliminar o habitat de Lymnaea, embora possa ser tentada a drenagem de áreas alagadiças. Outra possibilidade seria evitar o acesso dos animais aos locais de ocorrência do molusco, pelo menos nos períodos de maior risco de infecção. Porém, tais medidas são difíceis de serem colocadas em prática (ibidem).

Antes do lançamento do triclabendazole, as drogas disponíveis para o tratamento e controle da fasciolose eram closantel, clorsulon, rafoxanide e albendazole. Todos elas apresentam elevada eficácia contra os parasitas adultos, porém moderada (clorsulon) ou baixa eficácia (albendazole) contra as formas imaturas. A elevada eficácia de triclabendazole contra as formas imaturas e adultas dos parasitas resultou na utilização excessiva do produto e, em consequência, na seleção e emergência de populações de parasitas com resistência em várias áreas do mundo (ibidem). Os seguintes anti-helmínticos, com as respectivas dosagens, são utilizados no tratamento da fasciolose em ovinos: albendazol (4,75 mg/kg, via oral); closantel (de $7,5 \mathrm{mg} / \mathrm{kg}$ a10 mg/kg, via oral); nitroxinil (10 mg/kg, via subcutânea); rafoxanida $(7,5 \mathrm{mg} / \mathrm{kg}$, via oral $)$ e triclabendazole $(10 \mathrm{mg} / \mathrm{kg}$, via oral) (Echevarria, 2004).

\section{Referências bibliográficas}

AMATO, S. B. et al. Epidemiology of Fasciola hepatica Infection in the Paraíba River Valley, São Paulo, Brazil. Vet. Parasitol., [s. 1.], v.22, p.275-84, 1986.

BOAS FILHO, D. V. et al. Fasciola hepatica em bovinos na região metropolitana de Campinas (SP). In: CONGRESSO BRASILEIRO DE PARASITOLOGIA VETERINÁRIA, 16, Anais... Campo Grande - MS. 2010. CD-ROM.

ECHEVARRIA, F. Fasciolose. Rev. Bras. Parasitol. Vet., [s. 1.], v.13, supl. 1, p.100-2, 2004.

FISS, L. et al. Subacute and Acute Fasciolosis in Sheep in Southern Brazil. Parasitol. Res., [s. 1.], v.112, p.883-7, 2013.

MAURE, E. A. P. et al. Dinâmica de Lymnaea columella (Say, 1817), hospedeiro intermediário de Fasciola hepatica (Linnaeus, 1758) em 
municípios do estado de São Paulo, Brasil. Braz. J. Vet. Res. Anim. Sci., [s. 1.], v.35, p.151-5, 1998.

ROJO-VÁZQUEZ, F. A. et al. Update on Trematode Infections in Sheep. Vet. Parasitol., [s. 1.], v.189, p.15-38, 2012.

SCHMIDT, E. M. S. et al. Surto de Fasciola hepatica (Linnaeus, 1758) (Trematoda, Fasciolidae) em rebanho bovino na região de Botucatu, SP. In: XVI CONGRESSO BRASILEIRO DE PARASITOLOGIA VETERINÁRIA, Anais... Campo Grande. CD-ROM, 2010.

TAYLOR, M. A.; COOP, R. L.; WALL, R. L. Veterinary Parasitology. [S. 1.]: Blackwell Publishing, 2007. 904p.

TOSTES, R. A. et al. Casos autóctones de Fasciola hepatica na região de Presidente Prudente, São Paulo, Brasil. Cienc. Rural, [s. 1.], v.34, p. 961-2, 2004.

UENO, H.; GONÇALVES, P. C. Manual para diagnóstico das helmintoses de ruminantes. 4 ed. Tokyo: Japan International Cooperation Agency, 1998. 143p.

et al. Fascioliasis Problems in Ruminants in Rio Grande do Sul, Brazil. Vet. Parasitol., v.11, p.185-91, 1982.

UETA, M. T. Ocorrência de infecção natural de Fasciola hepatica Linnaeus, 1758 em Lymnaea columella Say, 1817 no Vale do Paraíba, SP, Brasil. Rev. Saúde Públ., [s. 1.], v.14, p.230-3,1980. 


\section{3 \\ Classe cestoda}

Os cestódeos apresentam o corpo com três regiões distintas: escólice (cabeça), colo (pescoço) e estróbilo. Nesta última região localizam-se as proglotes imaturas, maduras e grávidas. As proglotes maduras apresentam órgãos sexuais masculinos e feminos, e as proglotes grávidas apresentam o útero repleto com grande quantidade de ovos. Periodicamente, as proglotes grávidas desprendem-se do estróbilo e são eliminadas nas fezes do hospedeiro definitivo. No ambiente, os ovos são ingeridos pelos hospedeiros intermediários, e nestes ocorre a formação da forma larval do parasita. O hospedeiro definitivo infecta-se ao ingerir a forma larval presente nos tecidos do hospedeiro intermediário. Os ovinos podem atuar como hospedeiro definitivo de cestódeos, como é o caso de Moniezia spp., ou como hospedeiro intermediário de espécies que têm como hospedeiro definitivo os cães.

\section{Moniezia spp.}

Moniezia spp. é um parasita encontrado frequentemente no intestino delgado de ovinos (Figura 45). Os parasitas podem atingir até $2 \mathrm{~m}$ de comprimento por 1,6 cm de largura. O estróbilo é dividido em proglotes que são mais largas do que longas (Figura 46). Os ovos têm formato variável e podem parecer, grosseiramente, quadrangulares, triangulares ou arredondados (Figura 47). 
Figura 45 - Grande número de exemplares de Moniezia expansa em cordeiro que não apresentava sinais clínicos de verminose
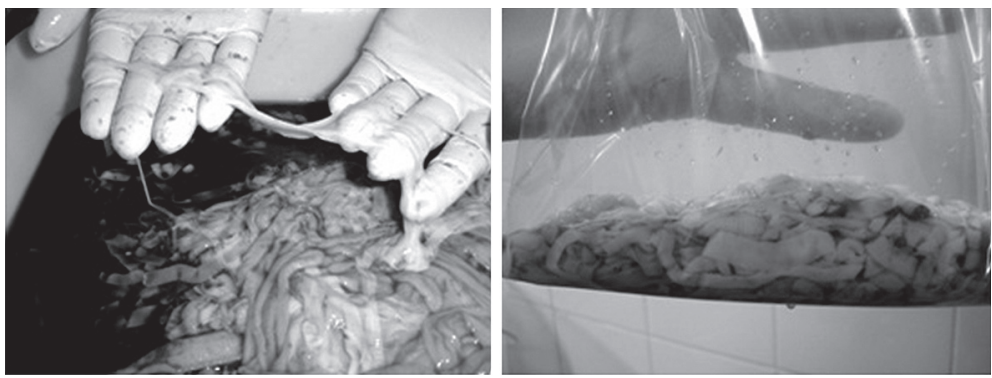

Foto gentilmente cedida por Bruna Fernanda da Silva

Duas espécies, Moniezia expansa e Moniezia benedeni, ocorrem no intestino delgado de ruminantes. Existem evidências de que a primeira espécie é parasita preferencial de ovinos, e a segunda, de bovinos. No Senegal, a prevalência de M. expansa foi de $25 \%$ e $11 \%$ em ovinos e caprinos, respectivamente, e nunca foi detectada em bovinos, enquanto a prevalência de $M$. benedeni foi de $4 \%$ e $17 \%$ em ovinos e bovinos, respectivamente (Ba et al., 1993).

Figura 46 - Proglotes maduros de Moniezia expansa com órgãos genitais masculinos e femininos

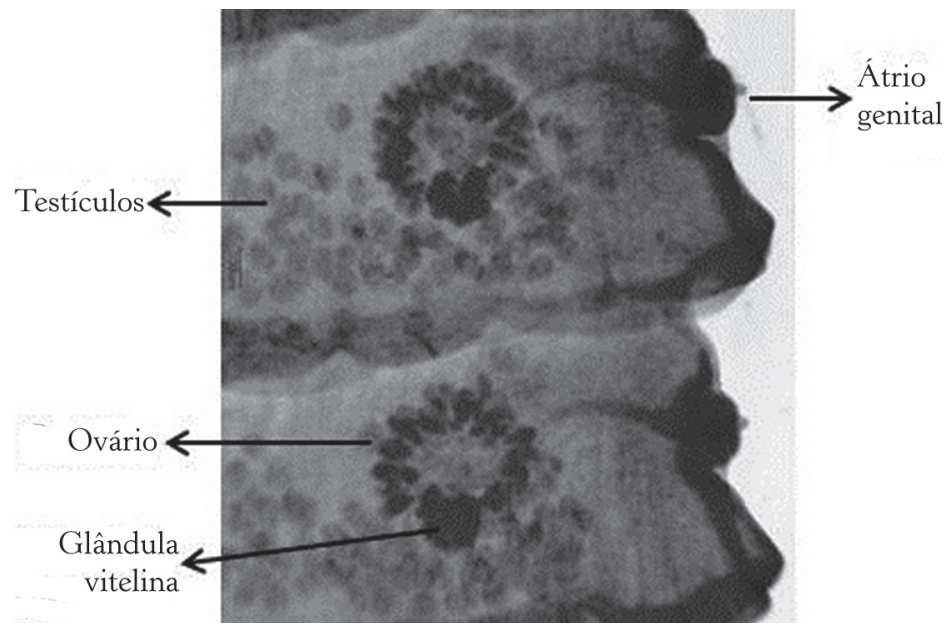


Figura 47 - Ovos de Moniezia spp.

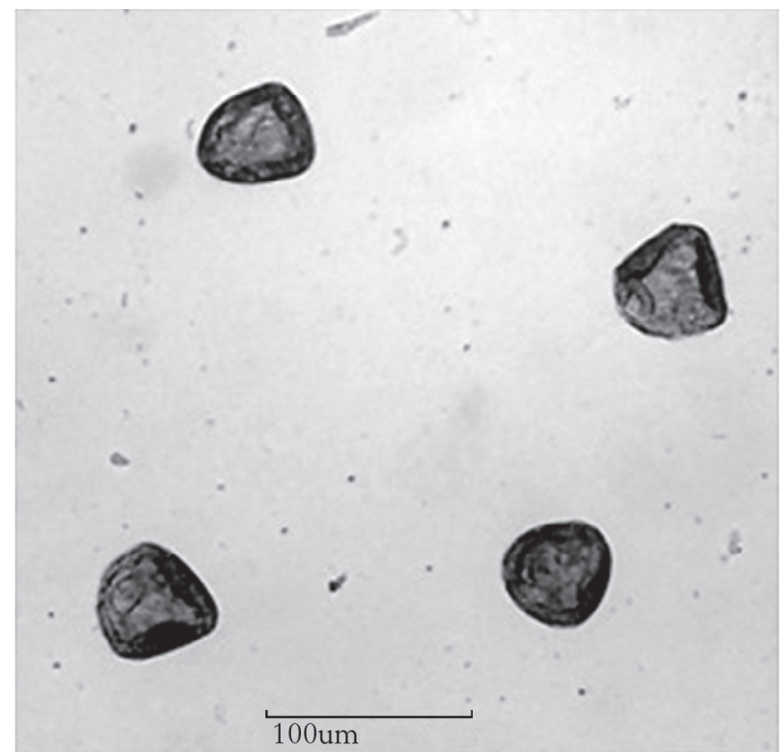

As proglotes repletas de ovos desprendem-se do estróbilo e podem ser eliminadas intactas nas fezes. Em meio aos cíbalos fecais, essas proglotes podem ser facilmente visualizadas e identificadas (Figura 48). No ambiente, os ovos são ingeridos pelos hospedeiros intermediários, ácaros oribatídeos, que habitam as pastagens. Nos tecidos do ácaro forma-se a larva cisticercoide, que é a forma infectante para o hospedeiro definitivo. Os ruminantes infectam-se ao ingerir esses ácaros juntamente com a pastagem.

Pelo menos oitenta espécies de ácaros oribatídeos têm sido citadas como hospedeiras intermediárias de M. expansa, e 38 de $M$. benedeni. Scheloribates laevigatus (Scheloribatidae), um ácaro que apresenta de $500 \mu \mathrm{m}$ a $600 \mu \mathrm{m}$ de comprimento, é considerado o principal hospedeiro intermediário das duas espécies de Moniezia. Em cultura mantida em laboratório, a taxa de infecção por S. laevigatus foi de 92,2\%, e a intensidade de infecção de foi de 2,9 cisticercoides por ácaro, sendo necessários 42 dias para o amadurecimento dos cisticercoides após a ingestão dos ovos (Xiao; Herd, 1992). 
Figura 48 - Proglotes de Moniezia spp. eliminadas nas fezes de um ovino

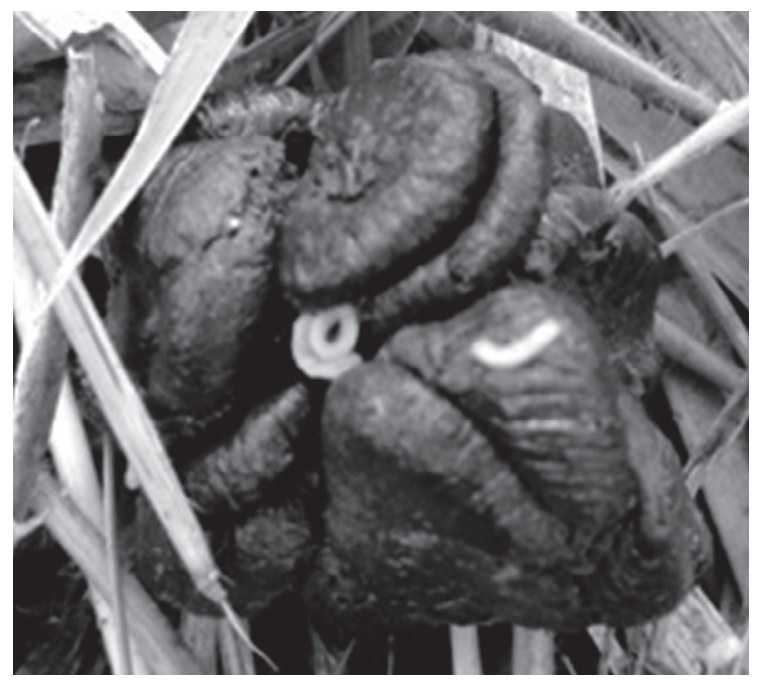

Foto gentilmente cedida por José Henrique das Neves

Os parasitas ocorrem em número variável, podendo-se encontrar dezenas em um único animal (Figura 45). De modo geral, são considerados pouco patogênicos para os hospedeiros, e as infecções costumam ser assintomáticas. Porém, estudos realizados no Marrocos (Mahin et al., 1991) e na Rússia (Krygina, 1989) demonstraram que cordeiros tratados com drogas eficazes contra Monieza apresentaram produtividade superior à de cordeiros não tratados. A niclosamida (100 mg/ kg) é altamente eficaz no tratamento da monieziose, porém os benzimidazóis também podem ser utilizados no combate a esse parasita (Gill et al., 1990).

\section{Tenídeos que parasitam cães e apresentam ovinos como hospedeiro intermediário}

Com relativa frequência, a forma larval de tenídeos é registrada em ovinos criados no Brasil. Os três principais parasitas estão apresentados na Tabela 13. 
Tabela 13 - Sumário dos tenídeos que parasitam cães (hospedeiros definitivos) e que já foram registrados em ovinos (hospedeiro intermediário) no Brasil

\begin{tabular}{l|c|c|c|c}
\hline \multicolumn{1}{c|}{ Espécie } & $\begin{array}{c}\text { Comprimento } \\
\text { do verme } \\
\text { adulto no } \\
\text { intestino do } \\
\text { cão }\end{array}$ & $\begin{array}{c}\text { Hospedeiros } \\
\text { intermediários }\end{array}$ & Larva & $\begin{array}{c}\text { Localização da } \\
\text { larva no ovino }\end{array}$ \\
\hline $\begin{array}{l}\text { Echinococcus } \\
\text { granulosus }\end{array}$ & $2-3 \mathrm{~mm}$ & $\begin{array}{c}\text { Ruminantes, } \\
\text { suínos, equinos, } \\
\text { homem }\end{array}$ & $\begin{array}{c}\text { Cisto } \\
\text { hidático }\end{array}$ & $\begin{array}{c}\text { Vísceras, } \\
\text { especialmente } \\
\text { fígado e pulmões }\end{array}$ \\
\hline $\begin{array}{l}\text { Taenia } \\
\text { multiceps }\end{array}$ & $40-100 \mathrm{~cm}$ & $\begin{array}{c}\text { Ruminantes, } \\
\text { especialmente } \\
\text { ovinos }\end{array}$ & $\begin{array}{c}\text { Coenurus } \\
\text { cerebralis }\end{array}$ & $\begin{array}{c}\text { Sistema nervoso } \\
\text { central }\end{array}$ \\
\hline $\begin{array}{l}\text { Taenia } \\
\text { hydatigena }\end{array}$ & $0,75-5 \mathrm{~m}$ & $\begin{array}{c}\text { Ruminantes e } \\
\text { suínos }\end{array}$ & $\begin{array}{l}\text { Cysticercus } \\
\text { tenuicullis }\end{array}$ & Peritônio \\
\hline
\end{tabular}

\section{Echinococcus granulosus - Hidatidose}

A hidatidose, também denominada equinococose cística, é uma importante zoonose causada pelo estágio larval de cestódeos do gênero Echinococcus. O ciclo de vida do parasita é indireto e requer dois hospedeiros mamíferos. $\mathrm{O}$ verme adulto apresenta tamanho reduzido, vive no intestino delgado do hospedeiro definitivo (cães e outros canídeos) e produz ovos, que são excretados com as fezes, contaminando dessa forma o ambiente. Várias espécies de animais domésticos e silvestres, e também a espécie humana, atuam como hospedeiros intermediários e adquirem a infecção ao ingerir os ovos. Os embriões que eclodem dos ovos desenvolvem-se nos órgãos internos, dando origem ao cisto hidático (metacestódeo). $\mathrm{Na}$ maioria dos casos, o cisto localiza-se no fígado ou nos pulmões, e em seu interior podem se formar milhares de protoescólices (cabeças invaginadas de Echinococcus). O ciclo completa-se quando os hospedeiros definitivos ingerem os órgãos infectados com cistos férteis, ou seja, portadores de protoescólices.

A hidatidose tem distribuição mundial e representa um problema sério de saúde humana e animal em algumas áreas de pecuária da América do Sul, região Mediterrânea da Europa, Norte e Leste 
da África, Ásia e Austrália. Entre todas as espécies que compõem o gênero Echinococcus, E. granulosus é quase que exclusivamente a espécie causadora de infecção em animais de produção. A análise de DNA mitocondrial tem demonstrado que E. granulosus é, na verdade, um complexo de espécies/genótipos que exibe grande variabilidade genética. Pelo menos dez genótipos distintos (G1G10) foram identificados dentro do complexo E. granulosus: duas cepas ovinas (G1 e G2), duas cepas bovinas (G3 e G5), uma cepa equina (G4), uma cepa de camelo (G6), duas cepas de suínos (G7 e G9) e duas cepas de cervídeos (G8 e G10). Os genótipos G1-G3 formam o taxon E. granulosus sensu stricto (E. granulosus s.s.). Essas variantes têm ampla distribuição geográfica, grande amplitude de especificidade parasitária, ocorrem simpatricamente e são responsáveis (particularmente G1) pela maioria das infecções humanas (Cardona; Carmena, 2013).

\section{Consequências da hidatidose na saúde pública e na produção animal}

A fase inicial da infecção primária é sempre assintomática. Cistos pequenos, devidamente encapsulados ou calcificados, usualmente não induzem alterações patológicas significativas, e os pacientes podem permanecer assintomáticos por anos ou permanentemente. A indução de morbidade depende do número, tamanho e estágio de desenvolvimento dos cistos (ativos ou inativos), do órgão envolvido, da localização do cisto dentro do órgão, da pressão exercida pelo cisto nos tecidos e nas estruturas adjacentes e dos mecanismos de defesa dos indivíduos infectados (Eckert; Deplazes, 2004).

A hidatidose tem impacto negativo na economia devido a vários fatores. O principal está relacionado com os elevados custos no tratamento dos casos humanos, que são usualmente bastante graves. A maioria dos registros indica que a mortalidade de humanos acometidos varia de $1 \%$ a $2 \%$. Além disso, os indivíduos podem apresentar comprometimento irreversível em sua qualidade de vida, o que obviamente pode afetar sua capacidade de trabalho. Além dos problemas relacionados à saúde pública, a hidatidose é importante 
causa de prejuízo econômico na pecuária. Os órgãos dos animais acometidos são condenados nos abatedouros. Além disso, existem evidências de que os ovinos infectados tendem a apresentar menor taxa de natalidade, menor conversão alimentar, menor produção de leite e lã de pior qualidade, em comparação com animais livres da enfermidade. Portanto, os prejuízos causados pela hidatidose resultam do somatório dos custos com os serviços médicos e dos prejuízos decorrentes da morbidade e da redução na produtividade animal (Torgerson, 2003).

O Rio Grande do Sul é o estado brasileiro com o maior percentual de casos de hidatidose humana e animal. A cepa ovina (G1) e a cepa bovina (G5) de E. granulosus foram registradas em animais de produção. Naquele estado, de seis pacientes humanos com hidatidose, quatro estavam infectados com o genótipo G1 (cepa ovina), um com G3 (cepa de búfalo) e um com G5 (cepa bovina). De doze cães parasitados por E. granulosus, dez apresentavam o genótipo G1 (cepa ovina), um, o genótipo G3, e outro, G5 (de la Rue et al., 2011).

\section{Taenia multiceps - Cenurose}

O sistema nervoso central dos ovinos pode ser parasitado pela forma larval da Taenia multiceps, denominada Coenurus cerebralis. Os cães, hospedeiros definitivos do cestódeo, albergam no intestino delgado os parasitas adultos. Os ovinos infectam-se ao ingerir os ovos de T. multiceps, eliminados nas fezes dos cães.

A infecção pode resultar em duas fases clínicas da enfermidade (Edwards; Herbert, 1982):

1) fase aguda, causada pela migração dos estágios pós-oncosfera no cérebro.

2) fase crônica, causada pelo deslocamento e pela atrofia dos tecidos cerebrais, resultantes da pressão provocada pelos cenuros em desenvolvimento.

A fase aguda da infecção ocorre de 9 a 33 dias após a infecção. Os animais podem apresentar febre, hemorragia da retina e distúrbios 
nervosos. Esses transtornos são atribuídos ao processo inflamatório difuso agudo que resulta das reações alérgicas e tóxicas que envolvem todo o sistema nervoso central. Os distúrbios neurológicos incluem ataxia, cegueira, tremor muscular e nistagmo. Os sintomas e a severidade da cenurose aguda dependem do grau de infecção, da intensidade da resposta inflamatória e, principalmente, da rota de migração do parasita (ibidem).

Nos animais sobreviventes, ocorre uma fase de quiescência após a fase aguda, durante a qual os cenuros amadurecem. Nessa fase os sintomas são leves ou ausentes. Os parasitas podem morrer durante a fase aguda e possibilitar a completa recuperação do animal. Nesse caso, lesões caseosas podem ser evidenciadas na necropsia. Os cenuros maduros também podem morrer devido à ação dos neutrófilos antes que os sintomas da cenurose crônica desenvolvam-se (ibidem).

Uma grande variedade de sinais clínicos ocorre durante o período de desenvolvimento do cenuro. Os sínais clínicos estão relacionados com o comprometimento das funções desempenhadas pelas diferentes regiões do cérebro acometidas. Em alguns casos de cenurose ocorrem desordens nervosas patognomônicas, como o torneio.

A infecção experimental de cordeiros, com mil a 5 mil ovos de $T$. multiceps, resultou em sinais clínicos de cenurose aguda em 13\% dos animais; $34,5 \%$ apresentaram cenuros vivos por ocasião da morte ou do abate, e 24,5\% apresentaram infecções no cérebro que não deram origem a larvas viáveis. A taxa de morbidade foi de 20,6\%, e a de mortalidade foi de $18,7 \%$. Na maioria dos casos clínicos, o número de larvas encontrado foi pequeno: uma larva em nove casos; duas larvas em oito casos; de três a sete larvas em nove casos; e dez ou mais larvas em sete casos. Uma grande proporção dos cordeiros infectados foi abatida antes do aparecimento de sinais clínicos (Herbert et al., 1984).

No diagnóstico diferencial, as seguintes enfermidades devem ser consideradas: listeriose, sarcocistose e polioencefalomalácia (Scott, 2012). Ocasionalmente, nos casos em que há osteomalácia, a localização do cenuro no cérebro pode ser determinada por 
palpação. Embora a remoção cirúrgica do cenuro seja possível, geralmente não é bem-sucedida (Edwards; Herbert, 1982). Porém, existem relatos de $85 \%$ de recuperação após a remoção cirúrgica dos cenuros que tenham sido localizados com precisão (Scott, 2012). O tratamento de ovinos experimentalmente acometidos por cenurose resultou na recuperação dos animais após administração de albendazole $(25 \mathrm{mg} / \mathrm{kg}$ ) por seis dias. Após o período de tratamento, ocorreu degeneração e calcificação dos cistos (Ghazaei, 2007).

\section{Taenia hydatigena - cisticercose}

Os parasitas adultos não são considerados patogênicos para os cães. T. hydatigena pode atingir até $5 \mathrm{~m}$ de comprimento e vive de 5,6 meses a 12 meses no intestino delgado dos cães. Sua importância restringe-se aos danos causados pelas larvas nos hospedeiros intermediários. Durante o período patente, de um a três proglotes podem ser eliminados por dia, porém, ocasionalmente cadeias de proglotes são eliminadas. O número médio de ovos produzidos em cada proglote grávido é de 53.800. Os proglotes encontrados nas fezes contêm apenas algumas centenas de ovos, o que demonstra que a maioria dos ovos é eliminada pelos proglotes ainda dentro do intestino. Os ovos eliminados no intestino delgado estão sujeitos à ação das enzimas digestivas, que podem estimular a eclosão, tornando-os inativos (Gregory, 1979; Gemmel et al., 1987). O número de vermes adultos presentes no intestino é proporcional ao número de cisticercos de T. hydatigena ingeridos, e o tamanho dos vermes é inversamente proporcional ao número de cestódeos presentes no intestino (Parmeter et al., 1981).

A larva da T. hydatigena, denominada Cysticercus tenuicullis, parasita ruminantes e suínos, que se infectam ao ingerir os ovos eliminados nas fezes dos cães. O embrião hexacanto desse cestódeo inicialmente realiza migrações no fígado. O cisticerco é encontrado aderido ao peritônio, onde atinge de $5 \mathrm{a} 8 \mathrm{~cm}$ de diâmetro (Figura 49). A larva é de fácil identificação, pois se apresenta, como uma vesícula de parede flácida e semitransparente, presa ao mesentério. 
Apenas o embrião hexacanto durante sua migração no parênquima hepático é considerado patogênico. Após a ingestão de ovos de $T$. hidatigena pelos ovinos, as larvas levam de de 34 a 53 dias para se tornarem maduras, ou seja, infectantes para os cães. Neste hospedeiro, as larvas de T. hidatigena podem permanecer vivas ao longo de toda a vida do animal (Gemmell; Lawson, 1985).

Figura 49 - Cysticercus tenuicollis, forma larval de Taenia hydatigena, localizada no mesentério de um ovino (a) e o cisto separado dos tecidos do hospedeiro (b)
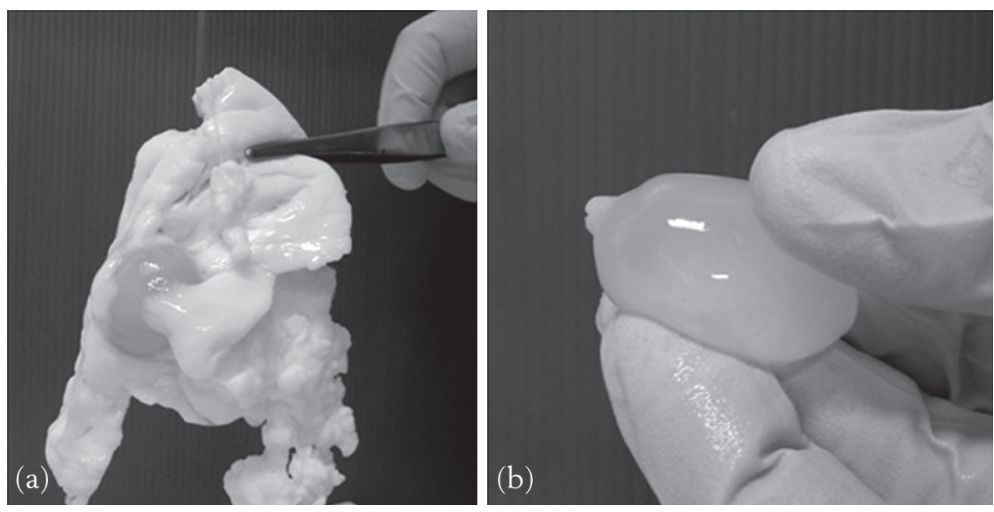

\section{Prevenção da hidatidose, cenurose e cisticercose}

A educação da população sobre os riscos e a importância da adoção de medidas de profilaxia é essencial para o controle e a erradicação dessas enfermidades. Os cães infectam-se quando ingerem vísceras de animais com cistos ou tecidos do sistema nervoso com larvas cenuro, o que permite que o ciclo dos parasitas se complete. Para prevenir a ocorrência dessas enfermidades, deve-se cozinhar adequadamente os produtos de origem animal que serão destinados à alimentação de cães, pois as temperaturas elevadas destroem a forma larval do parasita. Deve-se ainda evitar que os cães tenham acesso à carcaça de animais que porventura morram na propriedade.

Outras medidas, como a posse responsável, o controle da população canina e o tratamento de cães parasitados, são também 
imprescindíveis. Em campanhas de profilaxia, recomenda-se o tratamento de cães com praziquantel ( $5 \mathrm{mg} / \mathrm{kg}$ ), a cada seis semanas, para que seja interrompido o ciclo de E. granulosus, T. multiceps e T. hidatigena (Cabrera et al., 2002; Scott, 2012).

\section{Referências bibliográficas}

BA, C. T. et al. Diversity and Specificity in Cestodes of the Genus Moniezia: Genetic Evidence. Int. J. Parasitol., [s. 1.], v.23, p.853-7, 1993.

CABRERA, P. A. et al.Control of Echinococcus granulosus in Uruguay: Evaluation of Different Treatment Intervals for Dogs. Vet. Parasitol., [s. 1.], v.103, p.333-40, 2002.

CARDONA, G. A.; CARMENA, D. A Review of the Global Prevalence, Molecular Epidemiology and Economics of Cystic Echinococcosis in Production Animals. Vet. Parasitol., [s. 1.], v.192, p.10-32, 2013.

DE LA RUE, M. L. et al. Infection of Humans and Animals with Echinococcus granulosus (G1 and G3 Strains) and E. ortleppi in Southern Brazil. Vet. Parasitol., [s. 1.], v.177, p.97-103, 2011.

ECKERT, J.; DEPLAZES, P. Biological, Epidemiological, and Clinical Aspects of Echinococcosis, a Zoonosis of Increasing Concern. Clin. Microbiol. Rev., [s. 1.], v.17, p.107-35, 2004.

EDWARDS, G. T.; HERBERT, I. V. Observations on the Course of Taenia multiceps Infections in Sheep: Clinical Signs and Post-Mortem Findings. Br. Vet. J., [s. 1.], v.138, p.489-500, 1982.

GEMMEL, M. A.; LAWSON, J. R. The Survival in Sheep and Infectivity to Dogs of Taenia hydatigena and T. ovis in Sheep. Vet. Parasitol., [s. 1.], v.17, p.215-8, 1985.

GILL, J. S.; BALI, H. S.; MIGLANI, A. Comparative Efficacy of Anthelmintics Against Monieziasis in Sheep. Int. J. Parasitol., [s. 1.], v.14, p.137-9, 1990.

GHAZAEI, C. Evaluation Therapeutic Effects of Antihelminthic Agents Albendazole, Fenbendazole and Praziquantel Against Coenurosis in Sheep. Small Rumin. Res., [s. 1.], v.71, p.48-51, 2007.

GREGORY, G. G. Fecundity and Proglottid Release of Taenia ovis and Taenia hydatigena. AUST. VET. J., [s. 1.], v.52, p.277-9, 1976.

HERBERT, I. V.; EDWARDS, G. T.; WILLIS, J. M. Some Host Factors which Influence the Epidemiology of Taenia multiceps Infections in Sheep. Annals Trop. Med. Parasitol., [s. 1.], v.78, p.236-42, 1984. 
KRYGINA, E. A. Quality of Meat from Sheep Infested with Moniezia expansa, Before and After Anthelmintic Treatment. Vet. Moskva, [s. 1.], n.9, p.63-5, 1989.

MAHIN, L.; CHADLI, M.; ID-SIDI-YAHYA, K. Treatment Against Monieziasis by Suckling Lambs Deserves Precedence versus Trichostrongylosis Under Extensive Conditions in Morocco. Tropicultura, Belgium, v.9, p.177-80, 1991.

PARMETER, S. N.; HEATH, D. D.; TWAALFHOVEN, H. Effect of Population Density on Growth and Development of Taenia hydatigena in Dogs. Res. Vet. Sci., [s. 1.], v.30, p.257-9, 1981.

SCOTT, P. R. Diagnosis and Treatment of Coenurosis in Sheep. Vet. Parasitol., [s. 1.], v.189, p.75-8, 2012.

TORGERSON, P. R. Economic Effects of Echinococcosis. Acta Trop., [s. 1.], v.85, p.113-8, 2003.

XIAO, L.; HERD, R. P. Infectivity of Moniezia benedeni and Monieza expansa to Oribatid Mites from Ohio and Georgia. Vet. Parasitol., [s. 1.], v.45, p.101-10, 1992. 


\section{4 \\ ANTI-HELMÍNTICOS}

A maioria dos anti-helmínticos disponível no mercado foi desenvolvida a partir da década de 1960. Até recentemente, existiam apenas três grupos de anti-helmínticos de amplo espectro (benzimidazóis, imidazotiazóis e lactonas macrocíclicas). Uma nova molécula, denominada monepantel, foi recentemente desenvolvida (Kaminsky et al., 2008) e já está sendo comercializada no Brasil. Outra molécula, derquantel, que está sendo comercializada em associação com abamectina, foi lançada recentemente em alguns países (Little et al., 2011). Existem ainda anti-helmínticos de pequeno espectro utilizados especialmente para o controle de Haemonchus spp. e/ou Fasciola hepatica (Tabela 14).

A eficácia das drogas anti-helmínticas depende da disponibilidade sistêmica e do tempo de permanência da droga ativa no organismo do animal tratado. Para que ocorra um efeito sistêmico, o fármaco anti-helmíntico, administrado por via oral ou parenteral, deve ser absorvido e distribuído nos diferentes tecidos, até atingir concentrações adequadas no local parasitado (Lanusse et al., 2009). 


\section{O que levar em consideração na escolha de um anti-helmíntico?}

Em primeiro lugar, é necessário o conhecimento sobre a prevalência dos helmintos na região. Nos casos em que Haemonchus é o nematódeo predominante, pode-se utilizar um anti-helmíntico de pequeno espectro. Em segundo lugar, é importante que seja avaliada a eficácia do anti-helmíntico no rebanho, a qual é variável em função do histórico de utilização prévia da droga.

Erros no cálculo da dosagem do anti-helmíntico ocorrem com relativa frequência. Tais erros podem resultar na aplicação do anti-helmíntico em subdosagem, o que pode comprometer a eficácia do tratamento, ou na aplicação de dose elevada, que pode resultar na intoxicação dos animais. No geral, os riscos de intoxicação por benzimidazóis são baixos, enquanto que o oposto ocorre com o triclorfon, cuja dosagem terapêutica é muito próxima da dose que causa intoxicação (Tabela 15).

De todos os efeitos adversos produzidos pelos benzimidazóis, o mais importante é o risco de teratogênese. O problema é mais severo quando os animais são tratados na terceira semana de gestação, e os efeitos mais comuns manifestam-se com malformações esqueléticas (ibidem).

Outro problema está relacionado com a presença de resíduos na carne e no leite. A persistência do levamisol no plasma é de 6 a 8 horas e, em consequência, o efeito anti-helmíntico é de curta duração. Estima-se que $90 \%$ da dose administrada sejam excretados durante as primeiras 24 horas. Porém, estima-se em sete dias o período de carência, o qual depende da via de administração e do produto comercial em questão. Os animais tratados com nitroxinil não devem ser destinados ao consumo humano até sessenta dias após a administração, enquanto que closantel apresenta período de carência de trintas dias. Existem algumas variações na legislação dos países no que diz respeito às lactonas macrocíclicas; no geral, a carne de animais tratados não deve ser destinada ao consumo humano antes de 28 a 35 dias (ibidem). 
Tabela 14 - Anti-helmínticos utilizados no tratamento das helmintoses de ruminantes

\begin{tabular}{|c|c|c|c|}
\hline \multirow[t]{2}{*}{ Antiparasitário } & \multicolumn{3}{|c|}{ Espectro de ação } \\
\hline & Nematódeos & Moniezia spp. & Fasciola hepatica \\
\hline \multicolumn{4}{|l|}{ Benzimidazóis } \\
\hline \multicolumn{4}{|l|}{ Oxfendazol } \\
\hline \multicolumn{4}{|l|}{ Fenbendazol } \\
\hline Albendazol & & & *** \\
\hline \multicolumn{4}{|l|}{ Praziquantel } \\
\hline \multicolumn{4}{|l|}{ Triclabendazole } \\
\hline \multicolumn{4}{|l|}{ Imidazotiazóis } \\
\hline \multicolumn{4}{|l|}{ Levamisol } \\
\hline \multicolumn{4}{|l|}{ Lactonas macrocíclicas } \\
\hline \multicolumn{4}{|l|}{ Ivermectina } \\
\hline \multicolumn{4}{|l|}{ Abamectina } \\
\hline \multicolumn{4}{|l|}{ Doramectina } \\
\hline \multicolumn{4}{|l|}{ Moxidectina } \\
\hline \multicolumn{4}{|l|}{$\begin{array}{l}\text { Derivados de amino } \\
\text { acetonitrila }\end{array}$} \\
\hline \multicolumn{4}{|l|}{ Monepantel } \\
\hline \multicolumn{4}{|l|}{ Spiroindoles } \\
\hline \multicolumn{4}{|l|}{ Derquantel\# } \\
\hline \multicolumn{4}{|l|}{$\begin{array}{l}\text { Salicilanilidas/fenóis } \\
\text { substituídos }\end{array}$} \\
\hline Closantel & * & & \\
\hline Disofenol & * & & \\
\hline Rafoxanide & * & & \\
\hline \multicolumn{4}{|l|}{ Niclosamida } \\
\hline Nitroxynil & * & & \\
\hline \multicolumn{4}{|l|}{ Benzenosulfonamida } \\
\hline \multicolumn{4}{|l|}{ Clorsulon } \\
\hline \multicolumn{4}{|l|}{ Organofosforado } \\
\hline Triclorfon & * & & \\
\hline
\end{tabular}

*Atuam em nematódeos hematófagos, como Haemonchus.

***Albendazol atua apenas nas formas adultas de F. hepatica.

\#Derquantel está sendo comercializado associado a abamectina. 
Tabela 15 - Risco de intoxicação de ovinos devido à utilização de anti-helmínticos

\begin{tabular}{c|c}
\hline Anti-helmíntico & Risco \\
\hline Albendazole & Baixo \\
\hline Levamisol & Moderado \\
\hline Ivermectina e Moxidectina & Moderado \\
\hline Closantel & Alto \\
\hline Triclorfon & Muito alto \\
\hline
\end{tabular}

Fonte: observações pessoais do autor (informações não publicadas)

Além dos problemas apontados anteriormente, os resíduos dos anti-helmínticos podem ter impacto negativo no ambiente. Os anti-helmínticos são eliminados especialmente nas fezes dos animais que receberam tratamento. Após a administração, mais de $90 \%$ das moléculas de lactonas macrocíclicas são excretadas, pela bílis e fezes, como droga-mãe, sem se modificar. Portanto, as drogas podem ter impacto desfavorável especialmente na comunidade de invertebrados e microrganismos que utiliza as fezes para seu desenvolvimento e alimentação, os quais desempenham papel relevante na decomposição das fezes e na sua incorporação ao solo. A maioria dos estudos tem tido como foco o bolo fecal dos bovinos, enquanto que o impacto ambiental dos anti-helmínticos administrados aos ovinos permanece desconhecido (Beynon, 2012).

\section{Resistência anti-helmíntica}

A utilização dos anti-helmínticos indiscutivelmente propiciou aumento na produtividade dos rebanhos. Entretanto, os tratamentos frequentes tiveram como consequência a seleção de populações de helmintos com resistência aos diferentes grupos químicos, sendo que a resistência múltipla já está disseminada nos rebanhos de ovinos criados no Brasil há bastante tempo (Amarante et al., 1992; Echevarria et al., 1996; Thomaz-Soccol et al., 2004). Por essa razão, os anti-helmínticos devem ser usados de maneira criteriosa, apenas de modo complementar em esquemas de manejo que visem 
minimizar a utilização das drogas e ao mesmo tempo maximizar a produtividade do rebanho.

\section{Prejuízos decorrentes da resistência anti-helmíntica}

$\mathrm{Na}$ ausência de anti-helmíntico eficaz, não são raros os casos de mortalidade de ovinos, especialmente nas ocorrências de haemonchose. No entanto, são poucos os estudos destinados a avaliar os prejuízos econômicos decorrentes da administração de anti-helmínticos com eficácia reduzida, ou seja, devido à presença de populações de nematódeos resistentes. Um dos poucos estudos foi conduzido na Nova Zelândia, onde cordeiros receberam tratamento altamente eficaz com derquantel + abamectina ou tratamento com albendazol que apresentava baixa eficácia (48,4\% e 40,9\% em Trichostrongylus spp. e Teladorsagia circumcincta, respectivamente). Ao final de cinco meses de everminações mensais, os animais tratados com anti-helmíntico eficaz apresentaram em média $9 \mathrm{~kg}$ a mais do que os tratados com o vermífugo com baixa eficácia. Esse estudo demonstrou a relevância de avaliações de eficácia dos anti-helmínticos a fim de se evitar redução na produtividade (Miller et al., 2012).

\section{Recomendações para reduzir o desenvolvimento da resistência anti-helmíntica}

Algumas recomendações para reduzir o desenvolvimento e a disseminação de nematódeos resistentes estão descritas a seguir.

\section{Administrar o anti-helmíntico na dose correta}

O emprego de anti-helmínticos em subdosagem é provavelmente uma das causas que aceleram o aparecimento de populações de parasitas resistentes. Alguns dos animais a serem tratados devem ser pesados antes do tratamento, pois existe o risco de o ovinocultor subestimar o peso nas avaliações meramente visuais. As pistolas dosificadoras devem estar funcionando adequadamen- 
te, e os responsáveis pelo tratamento devem ter provetas graduadas para que possam aferir se as pistolas estão liberando a quantidade adequada do produto.

\section{Reduzir o número de tratamentos anuais}

Quanto mais frequentes forem os tratamentos com anti-helmínticos, mais rápido será o surgimento de populações de nematódeos resistentes. Técnicas de manejo que não requeiram a utilização frequente de anti-helmínticos devem ser adotadas.

\section{Os grupos de anti-helmínticos devem ser utilizados em esquema de rodízio anual}

Este tema é controverso, porém, existem evidências de que o aparecimento da resistência pode ser retardado quando os vermífugos são utilizados em esquema de rodízio anual (Waller et al., 1989). Além dos produtos com amplo espectro, pode-se também utilizar vermífugos de pequeno espectro, como o closantel, especialmente nas situações em que parasitas do gênero Haemonchus sejam predominantes.

\section{Utilização de anti-helmínticos em combinação}

Formulações que incluem a associação de princípios ativos com diferentes mecanismos de ação têm sido desenvolvidas. Após tratamento simultâneo com dois princípios ativos com diferentes mecanismos de ação, espera-se que a população de parasitas seja susceptível pelo menos a um deles. Um parasita resistente ao fármaco A seria eliminado pelo fármaco B e vice-versa, e dessa forma a eficácia desejada seria atingida (Lanusse et al., 2009). Obviamente que tal procedimento será pouco eficiente nos casos em que os parasitas apresentem resistência múltipla. Na Nova Zelândia, observou-se redução no desenvolvimento de resistência em T. colubriformis quando cordeiros foram tratados com a combinação levamisol + ivermectina. Porém, o mesmo procedimento foi insatisfatório no caso de $T$. circumcincta, que apresentou rápido desenvolvimento de resistência. Esses resultados indicaram que o 
procedimento adotado pode ser útil para reduzir a velocidade de desenvolvimento de resistência em algumas circunstâncias, porém, caso os parasitas já sejam resistentes à combinação (eficácia menor do que $70 \%$ ), os benefícios da associação de anti-helmínticos são grandemente reduzidos (Leathwick et al., 2012).

\section{Parasitas resistentes não devem ser adquiridos junto com os animais}

Os animais adquiridos devem ser tratados com um anti-helmíntico eficaz e ser mantidos isolados, em quarentena, antes de serem introduzidos no rebanho. Deve-se realizar exame de fezes desses animais antes de introduzi-los no rebanho, para se ter certeza de que eventuais infecções helmínticas foram eliminadas.

\section{As criações de ovinos devem ser avaliadas periodicamente para verificar a presença de nematódeos resistentes}

Antes de investir em tratamentos com anti-helmínticos, os ovinocultores deveriam investir na realização de exames laboratoriais para verificar se a aplicação de tratamentos é realmente necessária. Além disso, apenas com a realização de exames pré e pós-tratamento pode-se determinar se o anti-helmíntico utilizado em uma propriedade teve a eficácia esperada contra uma determinada população de helmintos.

\section{Os ovinos devem ser tratados com anti-helmíntico antes de serem colocados em uma pastagem "limpa"?}

A aplicação de um anti-helmíntico resulta na eliminação dos parasitas susceptíveis presentes nos animais tratados. Se o tratamento for realizado antes da transferência dos animais para uma área limpa, é de se esperar que essa pastagem seja contaminada apenas com os parasitas que sobreviveram ao tratamento, ou seja, com os descendentes dos nematódeos resistentes. Essa prática pode acelerar o aparecimento de populações de helmintos resistentes (Waghorn et al., 2009). Nesse caso, seria prudente manter parte do 
rebanho sem tratamento, a fim de garantir a introdução de helmintos susceptíveis na pastagem limpa.

Porém, a questão que se coloca é a seguinte: os esforços para descontaminar uma pastagem ainda seriam justificáveis, uma vez que nela serão colocados animais parasitados que promoverão sua imediata contaminação? No estado de São Paulo, observou-se que quando ovelhas eram colocadas, sem tratamento anti-helmíntico prévio, em pastagens descontaminadas, havia rápida contaminação dos piquetes com larvas infectantes, o que tornava o esforço para descontaminar a pastagem praticamente inútil do ponto de vista de profilaxia da verminose (Rocha et al., 2008).

Existem algumas evidências a favor do tratamento dos ovinos antes de colocá-los em pastagens "limpas". Estudos com modelos matemáticos indicaram que a utilização de pastagens permanentes em associação com tratamentos frequentes do rebanho acelera o desenvolvimento da resistência. Por outro lado, baixa frequência de tratamentos combinados com a transferência dos animais para pastagens "limpas" reduz o risco de seleção de parasitas resistentes (Gettinby et al., 1989). Em um experimento realizado ao longo de cinco anos na Austrália, não foram observadas evidências de que tratamentos anti-helmínticos de ovinos, combinados com a transferência dos animais para pastagem com baixa contaminação, tenham acelerado o desenvolvimento da resistência anti-helmíntica em comparação com os resultados obtidos em ovinos tratados e mantidos na mesma pastagem (Waller et al., 1989).

Os trabalhos anteriormente citados indicam que mais importante do que o tipo de manejo adotado é a frequência com que os anti-helmínticos são utilizados. Portanto, deve-se minimizar ao máximo a utilização dessas drogas a fim de retardar o aparecimento de populações resistentes, e, neste caso, práticas de descontaminação de pastagem podem ser úteis para propiciar redução na frequência de utilização dos anti-helmínticos. Além disso, deve-se evitar o tratamento simultâneo de todos os animais do rebanho. Como visto no item sobre a resposta imunológica dos animais, per- 
centual relativamente elevado de animais alberga poucos parasitas e não necessita de tratamento.

\section{Tratamentos estratégicos ou tratamentos seletivos?}

Os tratamentos estratégicos com anti-helmínticos são preconizados com o objetivo de reduzir ao máximo a carga parasitária nos animais durante a fase menos favorável à sobrevivência dos estágios de vida livre dos nematódeos no ambiente, o que acontece, por exemplo, durante a estação seca. $\mathrm{O}$ tratamento dos animais resultaria, assim, em redução na eliminação de ovos dos nematódeos para o ambiente com consequente redução na contaminação das pastagens quando as condições ambientais votassem a ser novamente favoráveis ao desenvolvimento dos estágios de vida livre. Animais menos expostos aos parasitas apresentariam maior produtividade. Esse tipo de controle tem sido questionado, pois pode aumentar a velocidade da seleção de parasitas resistentes, uma vez que os nematódeos sobreviventes ao tratamento, ou seja, os resistentes, serão os responsáveis pela recontaminação da pastagem quando as condições ambientais tornarem-se novamente favoráveis (Martin et al., 1981; Papadopoulos et al., 2001).

Por essa razão, estratégias com base na "Refugia" tem sido fonte de inúmeros estudos visando o controle parasitário sustentável. Revisão aprofundada sobre esse assunto foi publicada recentemente por Besier (2012). De acordo com o autor, programas de controle sustentável da verminose visam minimizar perdas econômicas devidas à redução na produtividade do rebanho e ao mesmo tempo prevenir a ocorrência das parasitoses, sem aumentar o nível da resistência anti-helmíntica. No conceito de "refugia" permite-se deliberadamente a sobrevivência de populações de nematódeos que não tenham sido recentemente expostas a tratamento. Os descendentes dos parasitas que não tiveram contato com o antiparasitário serão fonte de vermes susceptíveis, que atuarão "diluindo" a população de parasitas que porventura tenha sobrevivido ao tratamento, ou seja, "diluindo" a população de vermes resistentes. Com isso, 
espera-se que ocorra redução na taxa de desenvolvimento da resistência. Essa meta pode ser alcançada de duas maneiras: (1) modificação da estratégia de tratamentos a fim de permitir a sobrevivência dos estágios de vida livre dos parasitas na pastagem, ou (2) manter sem tratamento os animais que se mostrem capazes de suportar o parasitismo.

Pequenas alterações nas práticas usuais podem propiciar os benefícios da refugia, como manter sem tratamento $10 \%$ dos cordeiros, no caso, os mais pesados do lote (Leathwick et al., 2012).

\section{Tratamentos seletivos}

Existe grande variedade de abordagens que podem ser empregadas para identificar os animais que necessitam de tratamento. As principais são as seguintes:

\section{Exames coproparasitológicos}

No caso da realização de contagens de ovos por grama de fezes (OPG), recomenda-se o tratamento apenas dos animais ou categorias que apresentem valores elevados de OPG.

\section{FAMACHA $^{\odot}$}

Neste método, recomenda-se o tratamento apenas dos ovinos anêmicos (van Wyk; Bath, 2002). As avaliações têm por base um cartão com cinco tonalidades de vermelho, as quais correspondem aos seguintes valores de hematócrito em comparação com a respectiva coloração da conjuntiva ocular:

- Categoria 1: hematócrito $\geq 28 \%$

- Categoria 2: hematócrito de 23\% a 27\%

- Categoria 3: hematócrito de 18\% a 22\%

- Categoria 4: hematócrito de 13\% a 17\%

- Categoria 5: hematócrito $\leq 12 \%$.

Usualmente, recomenda-se o tratamento com anti-helmíntico dos animais classificados nas categorias 3 , 4 e 5 . 


\section{Consistência das fezes e variação no ganho em peso}

O grau de consistência das fezes e a variação no ganho em peso dos animais são outras variáveis que podem ser utilizadas como indicadoras da necessidade de tratamento dos animais com anti-helmíntico. Em estudo realizado na Argélia, onde os nematódeos predominantes em ovinos eram Teladorsagia circumcincta, Marshallagia marshalli, Nematodirus helvetianus, Trichostrongylus vitrinus e Haemonchus contortus, um escore relacionado à diarreia, denominado DISCO (diarrhoea score), foi o mais eficiente indicador de tratamento seletivo. Permitiu a identificação correta de $80 \%$ dos ovinos que necessitavam de tratamento. $\mathrm{O}$ método FAMACHA ${ }^{\circ}$ apresentou $50 \%$ de precisão, enquanto o ganho de peso não se mostrou eficiente. No sistema DISCO, as fezes são classificadas em três índices, de acordo com a consistência: "1" - cíbalos com consistência normal; "2" - fezes amolecidas (similar a bolo fecal de bovino); e " 3 " - diarreia (fezes semilíquidas). Esses índices correspondem a 40\%, 25\% e 15\% de matéria seca nas fezes, respectivamente (Bentounsi et al., 2012).

\section{Fatores que dificultam a adoção de estratégias com base na "refugia"}

Alguns fatores dificultam a adoção das metodologias anteriormente citadas. Os principais são os seguintes:

Sem tratamento, os animais podem apresentar redução significativa na produtividade e aumenta o risco de casos clínicos de parasitismo. No sistema FAMACHA, apenas os animais com haemochose clínica, ou seja, os anêmicos, são tratados. Obviamente, a produtividade de um animal que adoeceu (ficou anêmico) não será a mesma de um animal que se manteve saudável.

- Eficiência nem sempre comprovada de redução no desenvolvimento da resistência.

- Dificuldade na implantação devido a aumento nos custos, especialmente com mão de obra qualificada.

No caso de rebanhos pequenos, que sejam avaliados frequentemente por proprietários cuidadosos, os tratamentos seletivos 
podem se mostrar úteis. Para que os tratamentos seletivos apresentem impacto favorável na produtividade do rebanho, é necessária a utilização de um anti-helmíntico eficaz. Apenas com a realização de exames coproparasitológicos anterior e posterior ao tratamento é possível determinar se o tratamento teve a eficácia esperada. Além disso, é imprescindível que os animais tratados sejam devidamente identificados e que aqueles tratados frequentemente, ou seja, os com maior susceptibilidade, sejam eliminados do rebanho. Em rebanhos comerciais, com número elevado de animais, a adoção de tratamentos seletivos é mais complexa. Nesse caso, é mais factível manter sem tratamento as categorias mais resistentes, como ovelhas vazias, ou deixar de tratar parte dos animais, aqueles que se apresentarem com boa condição corporal.

Independentemente do tipo de utilização dos anti-helmínticos, estes devem ser empregados apenas como uma ferramenta complementar na profilaxia da verminose. Práticas racionais de manejo e a criação de animais geneticamente resistentes à verminose podem minimizar a necessidade da utilização dos vermífugos e ao mesmo tempo maximizar a produtividade do rebanho.

\section{Considerações finais}

No Brasil, devido às dimensões continentais, à grande diversidade de clima, às inúmeras raças e aos mais variados tipos de sistemas de criação, não é recomendável a elaboração de um esquema único para a profilaxia da verminose. Vale lembrar que calendários servem para indicar datas de vacinações, mas não para everminações do rebanho. Finalmente, é importante que o ovinocultor esteja ciente que: (a) a redução na produtividade do rebanho em decorrência da exposição aos parasitas pode inviabilizar economicamente a atividade; (b) a utilização de anti-helmínticos sem a avaliação de sua eficácia por meio de testes para detecção de resistência anti-helmíntica é frequentemente inútil, ou seja, é necessária a realização periódica de exames coproparasitológicos; e (c) animais 
bem nutridos e geneticamente resistentes à verminose dependem menos do uso profilático de anti-helmínticos.

\section{Referências bibliográficas}

AMARANTE, A. F. T. et al. Efeito da administração de oxfendazol, ivermectina e levamisol sobre os exames coproparasitológicos de ovinos. Braz. J. Vet. Res. Anim. Sci., [s. 1.], v.29, p.31-8, 1992.

BENTOUNSI, B.; MERADI, S.; CABARET, J. Towards Finding Effective Indicators (Diarrhoea and Anaemia Scores and Weight Gains) for the Implementation of Targeted Selective Treatment Against the Gastro-Intestinal Nematodes in Lambs in a Steppic Environment. Vet. Parasitol., [s. 1.], v.187, p.275-9, 2012.

BESIER, R. B. Refugia-Based Strategies for Sustainable Worm Control: Factors Affecting the Acceptability to Sheep and Goat Owners. Vet. Parasitol., [s. 1.], v.186, p.2-9, 2012.

BEYNON, S. A. Potential Environmental Consequences of Administration of Anthelmintics to Sheep. Vet. Parasitol., [s. 1.], v.189, p.113-24, 2012.

ECHEVARRIA, F. et al. The Prevalence of Anthelmintic Resistance in Nematode Parasites of Sheep in Southern Latin America: Brazil. Vet. Parasitol., [s. 1.], v.62, p.199-206, 1996.

GETTINBY, G. et al. Anthelmintic Resistance and the Control of Ovine Ostertagiasis: a Drug Action Model for Genetic Selection. Int. J. Parasitol., [s. 1.], v.19, p.369-76, 1989.

KAMINSKY, R. et al. A New Class of Anthelmintics Effective Against Drug-Resistant Nematodes. Nature, [s. 1.], v.452, p.176-80, 2008.

LANUSSE, C. E.; ALVAREZ, L. I.; LIFSCHITZ, A. L. Princípios farmacológicos da terapia anti-helmíntica. In: CAVALCANTE, A. C. R. et al. Doenças parasitárias de caprinos e ovinos: epidemiologia e controle. Brasília: Embrapa Informação Tecnológica, 2009. 603p.

LEATHWICK, D. M. et al. Managing Anthelmintic Resistance - Use of a Combination Anthelmintic and Leaving Some Lambs Untreated to Slow the Development of Resistance to Ivermectin. Vet. Parasitol., [s. 1.], v.187, p.285-94, 2012.

LITTLE, P. R. et al. Efficacy of a Combined Oral Formulation of Derquantel-Abamectin Against the Adult and Larval Stages of Nemato- 
des in Sheep, Including Anthelmintic-Resistant Strains. Vet. Parasitol., [s. 1.], v.181, p.180-93, 2011.

MARTIN, P. J.; LE JAMBRE, L. F.; CLAXTON, J. H. The Impact of Refugia on the Development of Thiabendazole Resistance in Haemonchus contortus. Int. J. Parasitol., [s. 1.], v.11, p.35-41, 1981.

MILLER, C. M. et al. The Production Cost of Anthelmintic Resistance in Lambs. Vet. Parasitol., [s. 1.], v.186, p.376-81, 2012.

PAPADOPOULOS, E.; HIMONAS, C.; COLES, G. C. Drought and Flock Isolation May Enhance the Development of Anthelmintic Resistance in Nematodes. Vet. Parasitol., [s. 1.], v.97, p.253-9, 2001.

ROCHA, R. A. et al. Sheep Grazing Alternately with Cattle: Parasitism and Decontamination of Pastures. Small Rumin. Res., [s. 1.], v.75, p.135-43, 2008.

THOMAZ-SOCCOL, V. Resistance of Gastrointestinal Nematodes to Anthelmintics in Sheep (Ovis aries). Braz. Arch. Biol. Technol., [s, 1.], v.47, p.41-7, 2004.

VANWYK, J. A.; BATH, G. F. The FAMACHA@ System for Managing Haemonchosis in Sheep and Goats by Clinically Identifying Individual Animals for Treatment. Vet. Res., [s. 1.], v.33, p.509-29, 2002.

WALLER, P. J. et al. Changes in Anthelmintic Resistance Status of Haemonchus contortus and Trichostrongylus colubriformis Exposed to Different Anthelmintic Selection Pressures in Grazing Sheep. Int. J. Parasitol., [s. 1.], v.19, p.99-110, 1989.

WAGHORN, T. S. et al. Drench-and-Shift is a High-Risk Practice in the Absence of Refugia. New Zeal. Vet. J., [s. 1.], v.57, p.359-63, 2009. 
PROTOZOÁRIOS 


\section{5 \\ EIMERIOSE}

Dez espécies de Eimeria parasitam ovinos, nos quais causam a enfermidade denominada eimeriose ou coccidiose (Tabela 16). A enfermidade acomete principalmente cordeiros e é caracterizada por diarreia, frequentemente aquosa, depressão, fraqueza, perda de peso e presença de grande quantidade de oocistos nas fezes.

Tabela 16 - Espécies de Eimeria que parasitam ovinos

\begin{tabular}{l|c|c}
\hline \multicolumn{1}{c|}{ Espécie } & Habitat (local parasitado) & Período pré-patente (dias) \\
\hline E. ahsata & Intestino delgado & $18-30$ \\
\hline E. bakuensis & Intestino delgado & $18-29$ \\
\hline E. crandallis & Intestino delgado e grosso & $15-20$ \\
\hline E. faurei & Intestino delgado e grosso & $13-15$ \\
\hline E. granulosa & Desconhecido & Desconhecido \\
\hline E. intrica & Intestino delgado e grosso & $23-27$ \\
\hline E. marcica & Desconhecido & $14-16$ \\
\hline E. ovinoidalis & Intestino delgado e grosso & $12-15$ \\
\hline E. pallida & Desconhecido & Desconhecido \\
\hline E. parva & Intestino delgado & $12-14$ \\
\hline
\end{tabular}

Fonte: Taylor et al. (2007).

\section{Morfologia e ciclo evolutivo de Eimeria spp.}

As espécies de Eimeria apresentam elevada especificidade parasitária, ou seja, não ocorrem infecções cruzadas entres as espécies que parasitam ruminantes. $\mathrm{O}$ ciclo de vida inclui multiplicação 
assexuada e sexuada. A multiplicação sexuada ocorre no intestino do hospedeiro e culmina com a formação dos oocistos, que são eliminados nas fezes (Figura 50).

Figura 50 - Oocistos de Eimeria spp. e ovos de Moniezia spp. em exame parasitológico de ovino

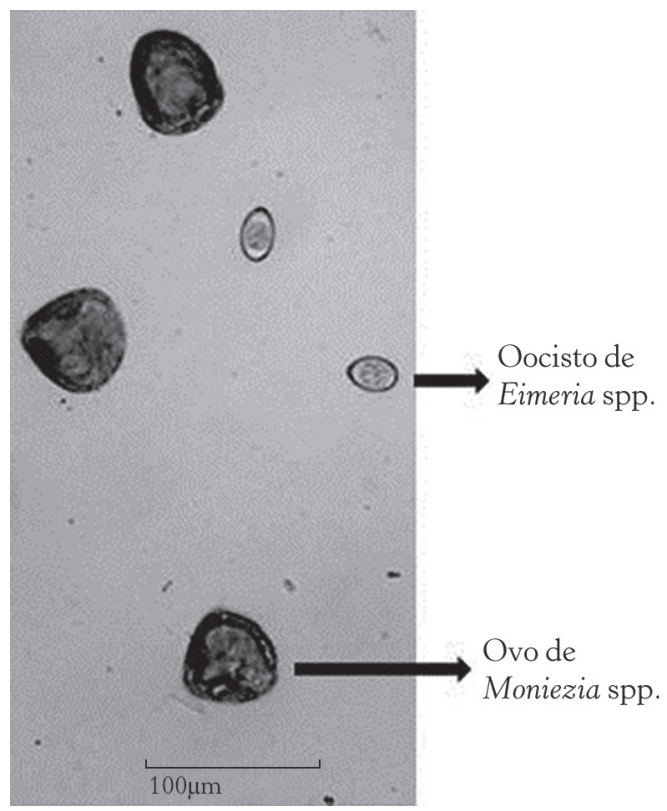

No ambiente, ocorre o desenvolvimento de oito microrganismos infectantes no interior dos oocistos, denominados esporozoítas. Após a ingestão do oocisto esporulado, os esporozoítas emergem e penetram nas células epiteliais ou na lâmina própria da mucosa. Dentro da célula do hospedeiro, arredondam-se sob a forma de trofozoíta, aumentam de tamanho e formam a primeira geração de esquizontes. Os esquizontes produzem uma primeira geração de merozoítas, que emergem da célula original e invadem células sadias para originar a segunda geração de esquizontes. Podem surgir diversas outras gerações esquizogônicas, mas duas ou três são o limite para a maioria das espécies de Eimeria. O número de 
gerações assexuadas, a localização do parasita na célula hospedeira e o número de merozoítas formados a cada geração variam em função da espécie de Eimeria. Um merozoíta produzido no final da esquizogonia penetra em uma célula não parasitada e desenvolve-se em uma forma masculina ou feminina denominada microgametócito ou macrogametócito, respectivamente. O gametócito feminino, quando maduro, é denominado macrogameta, enquanto que o masculino realiza divisões nucleares repetidas que culminam com a formação de vários microgametas. A fertilização com a produção do zigoto ocorre quando um microgameta une-se a um macrogameta. Uma parede forma-se ao redor do zigoto para formar o oocisto. Com a ruptura da célula hospedeira, o oocisto é eliminado para o ambiente com as fezes. Depois de um ou dois dias, sob condições adequadas de umidade, temperatura e oxigenação, ocorre a esporulação. Dentro de cada oocisto formam-se quatro esporocistos, e dentro de cada esporocisto, dois esporozoítas. O oocisto esporulado é a forma infectante do parasita (Bowman, 2010).

\section{Patogenia e sinais clínicos}

Várias espécies de Eimeria podem infectar simultaneamente os ovinos (Tabela 16), porém, apenas duas, E. crandallis e E. ovinoidalis, são consideradas altamente patogênicas. Em cordeiros com infecção pesada, a mucosa torna-se completamente destruída (Figura 51) resultando em hemorragia severa, a absorção fica prejudicada e ocorre diarreia, desidratação e morte. Em infecções mais leves, pode ocorrer prejuízo à absorção, com redução na eficiência da conversão alimentar (Taylor et al., 2007).

Dois fatores podem desencadear a ocorrência da coccidiose clínica: (a) ingestão massiva de oocistos esporulados em ambiente com elevada contaminação e/ou (b) multiplicação intensa dos parasitas no hospedeiro, devido à redução na resistência do animal. Essas duas situações podem coexistir em condições naturais. A manutenção de animais confinados ou em pastagem superlotada, 
Figura 51 - Mucosa intestinal de cordeiro com eimeriose aguda. Observar grande número de oocistos no interior da mucosa
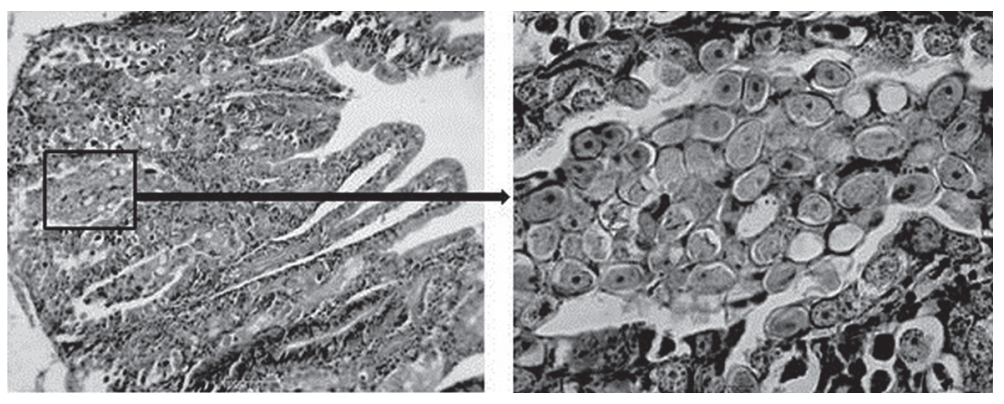

com acúmulo de fezes e umidade, favorece a contaminação massiva do ambiente e, em consequência, expõe os animais a alta taxa de infecção. Além disso, todos os fatores que sejam causa de estresse, tais como exposição a temperaturas extremas, desmama, transporte e outras enfermidades, podem prejudicar a resposta imunológica e favorecer a ocorrência de quadros clínicos da enfermidade (Chartier; Paraud, 2012).

Em animais saudáveis, mantidos em condições de manejo satisfatórias, a ingestão contínua de oocistos, em pequena quantidade, induz o desenvolvimento de resposta imunológica protetora, a qualé suficiente para limitar, mas não para extinguir a infecção. Isso pode ser facilmente comprovado em rebanhos de ovinos adultos, nos quais é usual o encontro de pequeno número de oocistos nas fezes.

Em cordeiros criados em pastagem, em uma lotação média de vinte ovinos adultos por hectare, em Botucatu (SP), verificou-se que o ápice na eliminação de oocistos, com médias próximas a 100 mil oocistos por grama de fezes (OPG), ocorreu quando os animais tinham de quatro a oito semanas de vida. Porém, não foram observados casos clínicos de coccidiose e, após a oitava semana de vida, houve decréscimo na eliminação de oocistos, indicando desenvolvimento de imunidade (Amarante et al., 1992). Porém, quando cordeiros da mesma propriedade foram desmamados e confinados, ocorreram casos clínicos e mortalidade devido à coccidiose. Dois 
animais sacrificados in extremis apresentaram contagens de 849.000 e 2.240.000 OPG e lesões esbranquiçadas irregulares de $3 \mathrm{~mm}$ a 6 $\mathrm{mm}$ de diâmetro no intestino delgado. No corte histológico observou-se comprometimento severo da mucosa devido à presença do parasita na sua fase endógena (idem, 1993). Nos cordeiros dessa propriedade foram registradas as seguintes espécies: E. parva, E. pallida, E. crandallis, E. ovinoidalis, E. intricada, E. ahsata, E. weybridgensis e E. bakuensis (idem, 1992).

No Rio Grande do Sul, foi relatada mortalidade de cordeiros com diarreia severa que estavam eliminando nas fezes grande quantidade de oocistos de Eimeria spp. e cistos de Giardia duodenalis. Os animais acometidos apresentaram sinais de recuperação três dias após o tratamento com sulphaquinoxaline $(20 \mathrm{mg} / \mathrm{kg}$ por três dias consecutivos) mais albendazol (100 mg/kg em dose única) (Bastiani et al., 2012).

\section{Diagnóstico}

Os animais clinicamente acometidos apresentam diarreia aquosa e fétida. Ao contrário do que ocorre com os bovinos, que nos quadros de eimeriose podem apresentar fezes com sangue (vermelho vivo), no caso dos ovinos, as fezes são eliminadas líquidas e apresentam coloração escura. Nos exames de fezes são observados milhares de oocistos, sendo muitas vezes difícil a quantificação destes em câmara de McMaster, devido ao número extremamente elevado.

\section{Profilaxia}

As infecções com pequeno número de oocistos induzem imunidade sem produzir doença clínica, sendo esta a regra em condições de criação extensiva. Por outro lado, medidas de higiene são fundamentais para que sejam evitados surtos da doença em criações intensivas ou semi-intensivas. 
As principais medidas para prevenir a eimeriose em ruminantes são:

- Evitar situações de estresse e assegurar aos animais alimentação de boa qualidade.

- Colocar cochos de ração e bebedouros em local e altura que evitem a contaminação com fezes.

- Os locais de confinamento devem ser mantidos limpos e secos, de preferência com piso impermeável ou de fácil drenagem.

- Os oocistos de Eimeria spp. são destruídos quando expostos ao sol. Portanto, é interessante que o piso do confinamento receba, pelo menos durante algumas horas do dia, luz solar direta.

Em alguns casos, faz-se necessário o tratamento preventivo ou curativo dos animais. Algumas drogas utilizadas no tratamento e na prevenção da coccidiose estão listadas na Tabela 17. Os produtos anticoccidia pertencem a vários grupos com diferentes modos de ação na fase endógena do parasita. As sulfonamidas têm atividade nos últimos estágios do ciclo, enquanto amprólio e ionóforos (monensina, lasalocide) têm efeito nos estágios iniciais. Decoquinato, toltrazuril e diclazuril são moléculas que atuam em todo o ciclo dos coccidia, o que permite seu emprego de forma curativa e preventiva. De forma curativa, amprólio e sulfonamidas devem ser administrados por um período de três dias a cinco dias, enquanto triazinonas (toltrazuril, diclazuril) devem ser administradas em dose única (Chartier; Paraud, 2012). Em animais confinados, a administração dos coccidiostáticos, monensina, lasalocida ou decoquinato, misturados à ração, costuma ser bastante eficiente na prevenção da coccidiose.

Os ionóforos são um tipo de antibiótico que, seletivamente, deprimem ou inibem o crescimento de microrganismos do rúmen e têm sido utilizados como promotores de crescimento em ruminantes confinados (Afonso et al., 2000). Além disso, a adição dessas drogas na ração pode prevenir a ocorrência de coccidiose. 
Tabela 17 - Drogas utilizadas no tratamento e na prevenção da coccidiose

\begin{tabular}{c|c}
\hline Grupo químico & Princípio ativo \\
\hline Quinolonas & Decoquinato \\
\hline & Toltrazuril \\
\hline Antibióticos ionóforos & Diclazuril \\
\hline & Monensina \\
\hline Análogos da tiamina & Lasalocide \\
\hline Sulfonamidas & Salinomycin \\
\hline & Amprólio \\
\hline & Sulfadimidina \\
\hline & Sulfaquinoxalina \\
\hline
\end{tabular}

\section{Referências}

AFONSO, J. A. B. et al. Características e indicações clínicas dos ionóforos para ruminantes. Rev. CFMV, n.20, p.29-36, 2000.

AMARANTE, A. F. T.; BARBOSA, M. A. Species of coccidia occurring in lambs in São Paulo State, Brazil. Vet. Parasitol., v.41, p.189-193, 1992.

AMARANTE, A. F. T.; BARBOSA, M. A.; SEQUEIRA, J. L. Coccidiose em cordeiros em Botucatu - SP, relato de dois casos. Rev. Bras. Parasitol. Vet., v.2, p.73-74, 1993.

BASTIANI, F. T. et al. Outbreak of eimeriosis and giardiasis associated to mortality of lambs in southern Brazil. Comp. Clin. Pathol., v.21, p.371-373, 2012.

BOWMAN, D. D. Georgis - Parasitologia Veterinária. Rio de Janeiro: Elsevier, 2010.

CHARTIER, C.; PARAUD, C. Coccidiosis due to Eimeria in sheep and goats, a review. Small Rumin. Res., v.103, p.84-92, 2012.

TAYLOR, M. A.; COOP, R. L.; WALL, R. L. Veterinary Parasitology. 3.ed. Blackwell Publishing, 2007. 


\section{6 \\ CRYPTOSPORIDIOSE}

Várias espécies de Cryptosporidium parasitam o trato gastrintestinal dos animais e do homem. Em ovinos, são duas as espécies principais: Cryptosporidium parvum e Cryptosporidium ubiquitum (Paraud; Chartier, 2012). Cryptosporidiose é a denominação da enfermidade causada por Cryptosporidium spp., a qual tem sido apontada como causa de diarreia neonatal em ruminantes. A enfermidade geralmente é mais severa em cabritos do que em cordeiros. Embora em alguns países a cryptosporidiose seja considerada importante causa de diarreia neonatal em cordeiros, até a presente data não foi apontada como problema sanitário em ovinos criados no Brasil. Portanto, infecções por Cryptosporidium spp., embora frequentes, são aparentemente bem toleradas pelos ovinos (Green et al., 2004; 2005). Os oocistos eliminados nas fezes apresentam tamanho reduzido (Figura 52). 
Figura 52 - Esfregaço de amostra fecal. Oocisto de Cryptosporidium spp. aparece indicado pela seta pela técnica de Ziehl-Neelsen

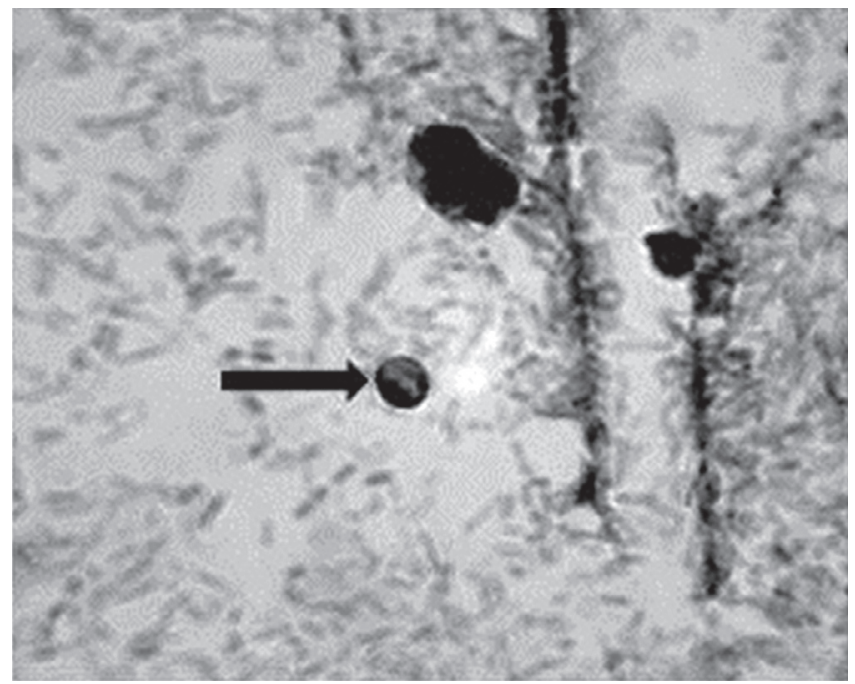

\section{Referências}

GREEN, R. E.; AMARANTE, A. F. T.; MASCARINI, L. M. The seasonal distribution of Cryptosporidium oocysts in sheep raised in São Paulo State. Rev. Bras. Parasitol. Vet., v.13, p.125-7, 2004.

. Patterns of shedding of cryptosporidial oocyst in ewes and lambs kept indoors. Braz. J. Vet. Res. Anim. Sci., v.42, p.204-9, 2005.

PARAUD, C.; CHARTIER, C. Cryptosporidiosis in small ruminants. Small Rumin. Res., v.103, p.93-7, 2012. 


\section{7 \\ TRIPANOSOMÍASE}

Das várias espécies do gênero Trypanosoma registradas no Brasil, apenas a espécie Trypanosoma vivax foi relatada como causa de problema clínico em ovinos. No Brasil, o primeiro surto de tripanosomose em ovinos e cabras causado por Trypanosoma vivax foi registrado na Região Nordeste em 2007. Os animais acometidos apresentavam episódios de febre, perda progressiva de peso, aborto e anemia (Batista et al., 2009). Posteriormente, outro surto foi registrado em uma propriedade da Paraíba, onde, dos 306 ovinos, 240 apresentaram sinais clínicos, e 216 morreram. Os sinais clínicos incluíram anorexia, letargia, anemia, perda de peso, edema submandibular, aborto e, em alguns casos, sinais nervosos. T. vivax foi identificado em esfregaços de sangue e por Reação em Cadeia pela Polimerase (PCR). Após o tratamento com diaceturato de diminazene ( $7 \mathrm{mg} / \mathrm{kg}$ ), a infecção foi completamente debelada, e nenhum parasita foi detectado nos esfregaços de sangue ou na reação de PCR. Bovinos e búfalos mantidos juntos com os ovinos também estavam infectados, porém sem apresentar sinais clínicos. No caso descrito nessa propriedade, $T$. vivax foi introduzido na fazenda provavelmente junto com búfalos portadores assintomáticos da infecção. O surto ocorreu durante a estação chuvosa, favorável ao aumento da população do vetor mecânico do parasita, as mutucas 
(Tabanus spp.). No caso desse surto, a utilização da mesma agulha para a aplicação de medicamentos durante a fase inicial da doença pode também ter favorecido a disseminação da enfermidade (Galiza et al., 2011). A trypanosomose ovina causada por T. vivax é uma enfermidade considerada de ocorrência rara na região semiárida do Brasil, mas que pode resultar em anemia, perda de peso, aborto e sintomas nervosos, e com grande probabilidade de levar à morte (ibidem).

No Pantanal brasileiro, T. vivax e Trypanosoma evansi são espécies muito comuns em animais domésticos, podendo causar perdas econômicas em bovinos e equinos. Ambas são transmitidas mecanicamente por insetos hematófagos, especialmente por mutucas (Tabanidae) e pela mosca dos estábulos (Stomoxys calcitrans). Infecções por $T$. vivax, com baixa parasitemia e ausência de sinais clínicos, é disseminada entre bovinos, ovinos e búfalos. Em 83 ovinos examinados, T. vivax foi detectado em 32 (38,6\%) animais por PCR, enquanto T. evansi não foi encontrado parasitando os ovinos (Davila et al., 2003). Em outro estudo realizado na mesma região, T. evansi também não foi detectado em ovinos. Por outro lado, essa espécie foi registrada com elevada parasitemia em capivaras (5/24), quatis (18/115), equinos (31/321) e cães (3/112). Entre esses, apenas as capivaras não apresentavam anemia. Baixas parasitemias foram ainda detectadas por PCR em búfalos (18/43), bovinos (29/331), marsupiais (1/4), pequenos roedores (14/67), morcegos (7/18) e em tatu (1/8). A prevalência mais elevada de $T$. evansi foi registrada em equinos (73\%), os quais não apresentavam sinais clínicos de infecção (Herrera et al., 2004).

Em conclusão, apenas T. vivax é causa de problemas clínicos em ovinos, especialmente quando animais parasitados, oriundos de regiões endêmicas, são introduzidos em áreas livres do parasita. Nesses casos, surtos de tripanossomose podem ocorrer com elevada mortalidade de ovinos. Por outro lado, em áreas endêmicas, nas quais os animais são expostos continuamente ao parasita, pode-se estabelecer equilíbrio na relação parasita-hospedeiro com ausência de problemas clínicos. 


\section{Referências bibliográficas}

BATISTA, J. S. et al. Infection by Trypanosoma vivax in Goats and Sheep in the Brazilian Semiarid Region: From Acute Disease Outbreak to Chronic Cryptic Infection. Vet. Parasitol., [s. 1.], v.165, p.131-5, 2009.

DAVILA, A. M. R. et al. Using PCR for Unraveling the Cryptic Epizootiology of Livestock Trypanosomosis in the Pantanal, Brazil. Vet. Parasitol., [s. 1.], v.117, p.1-13, 2003.

GALIZA, G. J. N. et al. High Mortality and Lesions of the Central Nervous System in Trypanosomosis by Trypanosoma vivax in Brazilian Hair Sheep. Vet. Parasitol., [s. 1.], v.182, p.359-63, 2011.

HERRERA, H. M. et al. Enzootiology of Trypanosoma evansi in Pantanal, Brazil. Vet. Parasitol., [s. 1.], v.125, p.263-75, 2004. 


\section{8 \\ TOXOPLASMOSE, NEOSPOROSE E SARCOCISTOSE ${ }^{1}$}

\section{Toxoplasma gondii}

\section{Introdução}

A toxoplasmose é uma zoonose de caráter cosmopolita, causada por Toxoplasma gondii, parasito intracelular obrigatório classificado no filo Apicomplexa, família Sarcocystidae, subfamília Toxoplasmatinae, que agrupa os gêneros Toxoplasma, Hammondia, Neospora e Besnoitia (Dubey, 1994a; Mugridge et al., 1999).

As primeiras descrições desse protozoário foram realizadas na França por Nicolle e Manceux, em 1908, em roedor silvestre (Ctenodactylus gundi)e, concomitantemente, no Brasil, Splendore o descreveu em coelhos. O termo Toxoplasma deriva do grego e decorre de seu formato em arco crescente (toxon = arco, plasma $=$ forma), e a palavra gondii é uma referência ao roedor no qual inicialmente

1 Capítulo de autoria de Alessandra M. A. Ragozo. Médica veterinária com mestrado(2003)edoutorado(2007)emEpidemiologiaExperimental AplicadaàsZoonoses pela Universidade de São Paulo (USP). Atualmente é assistente de suporte acadêmico do Departamento de Parasitologia, Instituto de Biociências, Universidade Estadual Paulista "Júlio de Mesquita Filho" (Unesp). Tem experiência na área de Parasitologia, com ênfase em Protozoologia Parasitária Animal, atuando principalmente nos seguintes temas: Toxoplasma gondii e Neospora caninum. 
foi descrito. Em 1909, o gênero Toxoplasma foi introduzido no filo Apicomplexa (Dubey; Beattie, 1988).

Além dos prejuízos econômicos, particularmente pelas perdas fetais, com grande relevância veterinária, $T$. gondii é reconhecido como importante agente de zoonose. Estima-se que aproximadamente um terço da população humana no mundo tenha sido exposta ao T. gondii (Dubey, 1998), porém a toxoplasmose geralmente apresenta-se assintomática ou de forma branda em indivíduos imunocompetentes (Tenter et al., 2000).

A toxoplasmose nos animais é uma importante causa de falhas reprodutivas ou abortamentos, principalmente na espécie ovina, na qual determina consideráveis perdas econômicas. Um estudo realizado no Uruguai apontou a toxoplasmose ovina como um importante problema sanitário, gerando prejuízos anuais entre US\$ 1,4 milhão a US\$ 4,7 milhões (Freyre et al., 1999).

No Brasil, a taxa de crescimento do mercado foi de 1,8 t/ano para a carne ovina (Couto, 2001) e a estimativa do rebanho ovino é de aproximadamente 17 milhões de cabeças. Nos últimos cinco anos, a ovinocultura paulista apresentou um crescimento de 29,5\% (IBGE, 2013). O consumo médio de carne ovina no Brasil é considerado baixo, cerca de $700 \mathrm{~g}$ por habitante/ano (Couto, 2001), porém a estimativa de consumo interno de carne ovina é crescente, mesmo com dados inferiores à realidade devido à informalidade na criação dessa espécie ser alta. Considerando-se que uma das formas de transmissão do $T$. gondii é pela ingestão de carne crua ou mal cozida contendo cistos teciduais do parasito, os ovinos podem representar uma importante fonte de infecção para o homem e para os animais carnívoros, especialmente em regiões onde a população possui o hábito de ingerir carne dessa espécie animal (Vitor et al., 1991; Dubey et al., 2012).

\section{Ciclo biológico}

Toxoplasma gondii é um parasito intracelular obrigatório, formador de cistos teciduais, que acomete o homem e outras espécies 
de mamíferos e aves (Black; Boothroyd, 2000). O ciclo biológico de T. gondii é heteroxeno facultativo, sendo o gato e outras espécies da família Felidae os únicos hospedeiros definitivos, nos quais ocorre a fase enteroepitelial caracterizada pela reprodução sexuada de desenvolvimento do protozoário, resultando na formação de oocistos, os quais são eliminados juntamente com as fezes para o ambiente. Nos felídeos, ocorre tanto a fase sexuada como a multiplicação extraintestinal (assexuada) do parasito (taquizoítos e bradizoítos). Nos hospedeiros intermediários, como o homem e os ovinos (Figura 53), ocorre unicamente a forma de multiplicação assexuada (Dubey, 1986).

Figura 53 - Ciclo biológico do Toxoplasma gondii

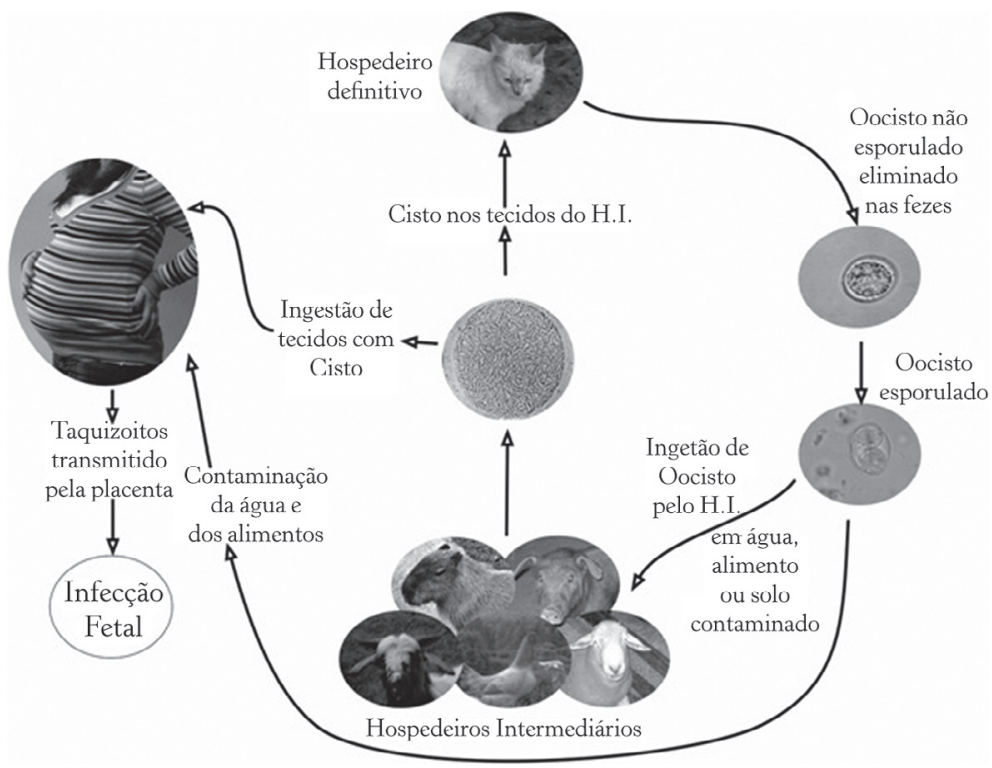

Os estágios infectantes do parasita são: (a) os taquizoítos (forma de multiplicação rápida), que ocorrem na fase aguda da toxoplasmose; (b) os bradizoítos (forma de multiplicação lenta - Figura 54), presentes em cistos teciduais, na fase crônica ou latente da infecção; 
e (c) os esporozoítos, presentes no interior dos oocistos (figuras 55 e 56), que são eliminados nas fezes de felídeos (idem, 1987). Os três meios primários para a difusão desse protozoário são a transmissão transplacentária, ingestão de tecidos animais contendo cistos infectantes e ingestão de alimentos e água contaminados com fezes de felídeos contendo oocistos esporulados.

Figura 54 - Bradizoítos de Toxoplasma gondii em cisto tecidual

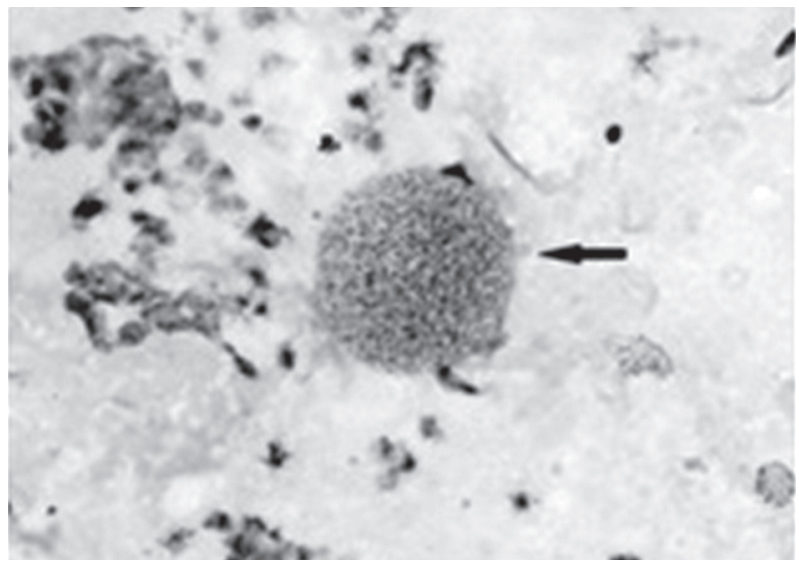

Figura 55 - Oocistos não esporulados de Toxoplasma gondii detectados pela técnica de centrífugo-flutuação em sacarose

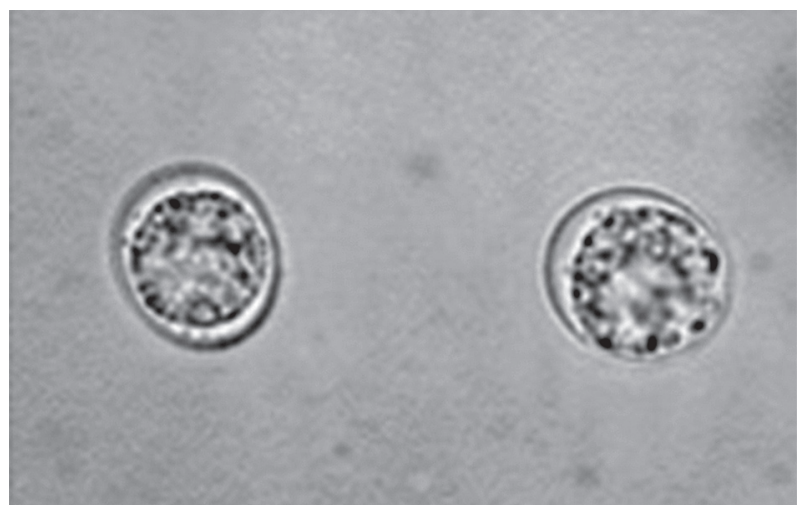

Foto gentilmente cedida por Marcelo de Souza Zanutto. 
Figura 56 - Esporozoítos contidos em oocistos esporulados de Toxoplasma gondii detectados pela técnica de centrifugo-flutuação em sacarose

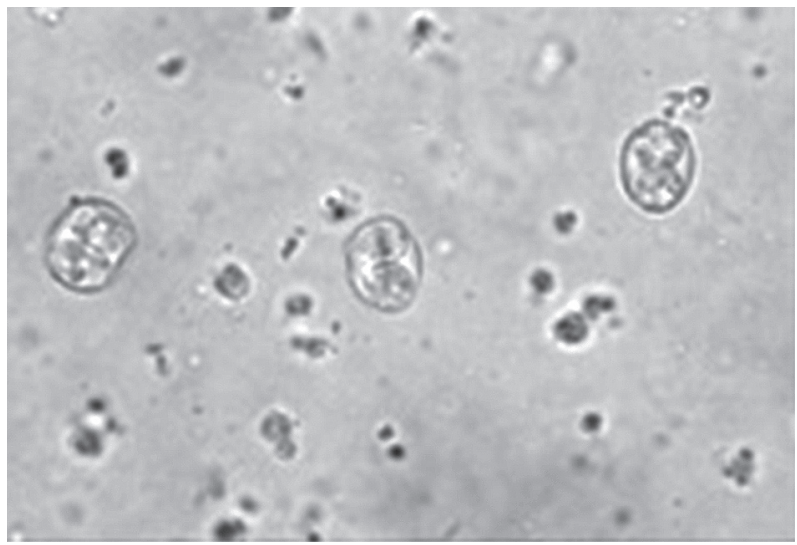

Foto gentilmente cedida por Marcelo de Souza Zanutto.

Considerando-se que uma das formas de transmissão de T. gondii é pela ingestão de carne crua ou mal cozida, os ovinos podem representar uma fonte de infecção para o homem e para os animais carnívoros (De Silva et al., 1984; Bonametti et al., 1997). Outro modo de transmissão é por meio do leite in natura, pois animais infectados experimentalmente podem eliminar o parasito no período de lactação (Dubey, 1980; Sacks et al., 1982; Chiari; Neves, 1984; Vitor et al., 1991). No leite, T. gondii sobrevive por sete dias à temperatura de $4{ }^{\circ} \mathrm{C}$ (Walsh et al., 1999).

Há relatos recentes da possibilidade de transmissão venérea em ovelhas inseminadas com sêmen contaminado com taquizoítos de $T$. gondii (Lopes et al., 2009; 2013; Santana et al., 2010). Fêmeas soronegativas produziram cordeiros infectados após monta natural com reprodutores experimentalmente infectados (Lopes et al., 2013).

\section{Sinais clínicos em ovinos}

A toxoplasmose é relativamente comum em pequenos ruminantes, com formação de cistos latentes que podem persistir durante 
a vida do hospedeiro, que pode se manter sem apresentar sinais clínicos da infecção (Mainar et al., 1996). A toxoplasmose clínica geralmente se manifesta na primoinfecção de ovelhas gestantes, resultando na transmissão transplacentária para o feto. A imunidade adquirida após a infecção persiste por toda a vida do animal, e raramente as ovelhas apresentarão novamente problemas reprodutivos causados por T. gondii (Dubey; Kirkbride, 1990; Esteban-Redondo; Innes, 1997). Ovelhas não gestantes susceptíveis geralmente não apresentam sintomatologia (Vaughan, 1996), e a infecção resulta na formação de cistos no tecido nervoso e muscular (Marca et al., 1996). Os machos reprodutores infectados não apresentam alterações específicas devido à infecção por $T$. gondii, porém, no período da fase aguda da infecção, podem eliminar taquizoítos pelo sêmen (Lopes et al., 2009; Santana et al., 2010; Dubey, 2010).

A toxoplasmose pode ser causa importante de problemas reprodutivos em rebanhos ovinos, com consideráveis perdas econômicas. Os sinais clínicos típicos da infecção por T. gondii são ocorrências de abortamentos, repetição de cio, malformações fetais, nascimento de animais prematuros ou debilitados e mortes neonatais (Buxton et al., 2007a). A severidade da infecção no feto varia de acordo com o estágio da gestação. No início, as consequências são mais graves e podem resultar em morte fetal e reabsorção, aparentando infertilidade. A infecção de ovelhas com dois a quatro meses de gestação pode resultar no nascimento de cordeiro natimorto, fraco ou ainda na formação de feto mumificado (Innes et al., 2009). Além do abortamento, placentite severa e mumificação também podem ocorrer devido à infecção na segunda metade gestacional (Vaughan, 1996).

Outro fator importante na determinação da gravidade da doença é a capacidade da resposta imune fetal contra o parasita, que aumenta com a idade gestacional do feto (Innes; Vermeulen, 2006). A partir de setenta dias de gestação, o feto já consegue responder à infecção. No final do período gestacional, a infecção pode resultar no nascimento de cordeiros clinicamente normais e viáveis, porém infectados (Buxton et al., 2007b). Em ovinos experimentalmente infectados, o abortamento é frequentemente observado, assim 
como reabsorção fetal e nascimento de cordeiros fracos ou prematuros. Nas ovelhas adultas constatou-se pirexia e aumento da frequência respiratória, mas nenhum outro sinal clínico foi observado (Owen et al., 1998). Foram obtidos cistos teciduais viáveis em amostras de coração, cérebro e musculatura esquelética de ovinos experimentalmente inoculados (Esteban-Redondo et al., 1999).

\section{Diagnóstico}

No feto abortado não há lesões macroscópicas patognomônicas características de toxoplasmose, porém, ao exame microscópico, observa-se frequentemente encefalite não supurativa com infiltrado de células mononucleares. Macroscopicamente, a placenta infectada pode apresentar pequenos nódulos esbranquiçados que são observados nos cotilédones (Innes, 1997; Dubey, 2010).

Exames histológicos, sorológicos, isolamento e detecção de DNA de T. gondii auxiliam no diagnóstico da toxoplasmose. Em caso de abortamentos, podem-se observar alterações nos cotilédones placentários, entretanto, a má conservação do material e a autólise prejudicam a análise do material, não sendo o procedimento mais indicado (Dubey; Kirkbride, 1984; Dubey, 2010). Na toxoplasmose congênita, exames sorológicos de fluídos fetais, do cordeiro antes da amamentação e da ovelha infectada, são os procedimentos mais recomendados (Dubey, 2010). Testes sorológicos, tais como Teste de Aglutinação Modificado (MAT), Reação de Imunofluorescência Indireta (RIFI) e Teste de ELISA, são os mais utilizados para detectar anticorpos anti- $T$. gondii e fornecer informações sobre a ocorrência do agente no rebanho.

Para a detecção do protozoário em amostras teciduais, é recomendado o isolamento em cultivo celular ou em animais de laboratório. Além do isolamento, a utilização de animais de laboratório possibilita o estudo da virulência da cepa (Pena et al., 2008; Ragozo et al., 2008; Dubey, 2010). Para um bom resultado no isolamento, recomenda-se o envio do material (tecido e/ou placenta) imediatamente ao laboratório, sob refrigeração. 
Para a detecção de DNA do protozoário, o método utilizado é a Reação da Cadeia pela Polimerase (PCR), com enzimas de restrições (RFLP) (Yai et al., 2009; Soares et al., 2011, Pena et al., 2013), ou ainda a PCR em tempo real (Gutierrez et a., 2012; Juránková et al., 2013).

\section{Epidemiologia}

O parasito ocorre de forma cosmopolita, e o principal modo de transmissão é pela ingestão de oocistos presentes no ambiente ou de cistos teciduais em carne de animais infectados (Dubey, 1994b). Nos ovinos, além da possibilidade de infecção pela ingestão de oocistos (Hill; Dubey, 2002), a transmissão transplacentária é considerada uma importante via de transmissão (Duncanson et al., 2001; Dubey et al., 2010).

A prevalência de anticorpos anti- $T$. gondii varia nas populações, com valores de soropositividade entre 10\% e 80\% em humanos de vários países. Essa variação entre os grupos étnicos está intimamente ligada a aspectos ambientais e socioculturais, como condições higiênico-sanitárias e hábitos alimentares (Tenter et al., 2000).

Em ovinos, relatos da prevalência de anticorpos anti- $T$. gondii têm sido descritos em vários países do mundo. Estudos epidemiológicos do agente em ovinos indicam valores que variaram de 3,8\% a 95,4\% de soroprevalência em mais de cinquenta países (Dubey et al., 2010). É certo que foram utilizados vários testes sorológicos e diferentes pontos de corte, porém, esses resultados demonstram a disseminação mundial do agente nos rebanhos. No Brasil, recentemente foi publicada uma revisão com vários estudos de soroprevalência do agente em ovinos procedentes de diversos estados, nos quais foram utilizados diferentes métodos sorológicos, que revelaram diferentes índices de soropositividade (idem, 2012). A Tabela 18 sumariza a ocorrência de anticorpos anti- $T$. gondii e apresenta variações na ocorrência de anticorpos entre 7\% e 59\% em animais de diferentes regiões brasileiras. 
Tabela 18 - Soroprevalência de anticorpos anti- T. gondii em ovinos criados no Brasil

\begin{tabular}{|c|c|c|c|}
\hline Estado & $\mathbf{N}^{\circ}$ & $\%$ positivos & Autoria \\
\hline Alagoas & 432 & 32,9 * & Pinheiro Jr. et al. (2008) \\
\hline \multirow[t]{2}{*}{ Bahia } & 45 & $18,8 ¥$ & Gondim et al. (1999) \\
\hline & 100 & $23^{凶}$ & do Amaral et al. (1978) \\
\hline Distrito Federal & 1.028 & $38,2 *$ & Ueno et al. (2009) \\
\hline \multirow[t]{2}{*}{ Minas Gerais } & 155 & $46,5^{*}$ & Rossi et al. (2011) \\
\hline & 370 & $47,8^{*}$ & Freire et al. (1995) \\
\hline \multirow[t]{7}{*}{ Paraná } & 118 & $51,8^{* * * *}$ & Garcia et al. (1999) \\
\hline & 157 & $51,4^{*}$ & Romanelli (2007) \\
\hline & 43 & $25,8^{* * *}$ & Gazda et al. (2006) \\
\hline & 305 & $51,5^{*}$ & Romanelli et al. (2007) \\
\hline & 339 & $54,6 *$ & Ogawa et al. (2003) \\
\hline & 157 & 7 & de Moura et al. (2007) \\
\hline & 167 & $25,7^{* * *}$ & Soccol et al. (2009) \\
\hline \multirow[t]{3}{*}{ Pernambuco } & 61 & $35,3^{*}$ & Silva et al. (2003) \\
\hline & 124 & $48,4 *$ & Bispo et al. (2011) \\
\hline & 97 & 59* & Costa et al. (2012) \\
\hline \multirow[t]{2}{*}{ Rio G. do Norte } & 409 & $20,7^{*}$ & Soares et al. (2009) \\
\hline & 102 & 29,4 *** & Clementino et al. (2007) \\
\hline $\begin{array}{l}\text { Rio G. do Sul e } \\
\text { Santa Catarina }\end{array}$ & 522 & $7,7^{*}$ & Silva; Langoni (2001) \\
\hline \multirow[t]{7}{*}{ Rio G. do Sul } & 92 & $9,8^{*}$ & Silva et al. (1980) \\
\hline & 100 & $39 \#$ & Larsson et al. (1980) \\
\hline & 655 & $8,0 ¥$ & Nishihawa et al. (1980) \\
\hline & 218 & $12,8^{*}$ & da Silva et al. (1981) \\
\hline & 662 & $18,2^{\alpha}$ & Zonta et al. (1987; 1988) \\
\hline & 144 & $30,5 ¥$ & Martins et al. (1998) \\
\hline & 123 & $39 *$ & Silva e de la Rue (2006) \\
\hline Rondônia & 141 & $46,8^{*}$ & Cavalcanti et al. (2004) \\
\hline \multirow[t]{9}{*}{ São Paulo } & 177 & $22,5^{*}$ & Sequeira et al. (1993) \\
\hline & 522 & $7,7^{*}$ & Silva e Langoni (2001) \\
\hline & 23 & $23 *$ & Silva et al. (2002) \\
\hline & 62 & $31 *$ & Meirelles et al. (2003) \\
\hline & 64 & $14,5^{*}$ & Mainardi et al. (2003) \\
\hline & 207 & $34,7 *$ & Figliuolo et al. (2004a) \\
\hline & 495 & $24,2^{f}$ & Ragozo et al. (2008) \\
\hline & 488 & $52 *$ & Lopes et al. (2010) \\
\hline & 382 & $18,6^{*}$ & Langoni et al. (2011) \\
\hline
\end{tabular}

Método de diagnóstico: ¥ LAT, *RIFI, **ELISA, £MAT \#Dye Test (DT), “IHA

Fonte: adaptado de Dubey et al. (2012). 
Apesar de o parasita apresentar uma fase sexuada em seu ciclo biológico com oportunidade de recombinação genética no hospedeiro definitivo (Dardé et al., 1992; Sibley; Boothroyd, 1992; Howe; Sibley, 1995), os primeiros estudos que envolveram epidemiologia molecular evidenciaram que diferentes isolados de $T$. gondii apresentaram-se similares na capacidade de infectar vários hospedeiros, nas características morfológicas e antigênicas, e ainda apresentaram baixa variação genética, quando foram analisados por meio do polimorfismo do comprimento de RFLP (Cristina et al., 1991; Sibley; Boothroyd, 1992) ou marcadores isoenzimáticos (Dardé et al., 1992), revelando, nessas amostras, uma estrutura populacional clonal (Howe; Sibley, 1995).

A clonalidade observada entre os isolados de $T$. gondii é manifestada pelo isolamento repetitivo do mesmo genótipo em amostras não relacionadas e pela ausência dos vários genótipos recombinantes possíveis. Assim, observou-se que amostras do agente isoladas do homem e dos animais podiam ser agrupadas em três linhagens clonais, designadas como tipos I, II e III (Dardé et al., 1992; Howe; Sibley, 1995). Entretanto, a partir de estudos similares com amostras obtidas na América do Sul, foi observado comportamento diferente dos descritos anteriormente com genótipos não correspondentes aos clonais (Dubey et al., 2002; 2012; Ragozo et al., 2008; Pena et al., 2008; Soares, et al., 2011).

A partir de 2002, foram iniciados vários estudos sobre a virulência e estrutura populacional de isolados do $T$. gondii de diversas espécies animais utilizando dez marcadores moleculares. Estudos baseados na Reação em Cadeia pela Polimerase (PCR) e no Polimorfismo do Comprimento dos Fragmentos de Restrição (RFLP) do parasito revelaram diversidade em amostras brasileiras e repetição de genótipos encontrados com maior frequência no Brasil, possibilitando a padronização de quatro linhagens: tipo BrI, BrII, BrIII e BrIV. Com a utilização de marcadores microssatélites, também foram reconhecidas diferenças no genótipo entre os isolados brasileiros e os de distribuição mundial (Lehmann et al., 2006). Estudos 
de virulência dos isolados de T. gondii, com base na mortalidade de camundongos, permitiram a classificação dos genótipos brasileiros em: BrI altamente virulento, BrII e BrIV medianamente virulentos e BrIII não virulento (Pena et al., 2008; 2013; Ragozo et al., 2008; Yai et al., 2009; Soares et al., 2011).

Apesar de poucos trabalhos de genotipagem de isolados de ovinos naturalmente infectados, observou-se a ocorrência de diferenças genotípicas, semelhantes às observadas anteriormente em outras espécies de animais do Brasil (Pena et al., 2008), divergindo do padrão clonal de isolados da América do Norte e Europa. É evidente que amostras de T. gondii isoladas no Brasil apresentam alta diversidade genotípica, contudo, até o momento não foi demonstrada preferência de um genótipo por um determinado hospedeiro, ou seja, os vários genótipos podem infectar diferentes espécies de animais (Dubey et al., 2012).

\section{Profilaxia}

Para a prevenção da toxoplasmose, há relatos de tratamento profilático com decoquinato ou monensina durante a gestação, a fim de reduzir a incidência de abortamento (Buxton et al., 1993; Pugh, 2004; Dubey, 2012), porém, esse protocolo é pouco utilizado. Além do mais, o abortamento é observado apenas na primoinfecção, não ocorrendo nas gestações subsequentes.

Até o momento, há uma vacina comercialmente disponível na Europa e Nova Zelândia (Toxovax ${ }^{\circledR}$, Intervet Shering-Plough), composta por taquizoítos atenuados da cepa S48. Sua administração é realizada três semanas antes do início da estação de monta, sendo observada resposta imune contra infecção natural que persiste por aproximadamente dezoito meses. Apesar de ser possível detectar taquizoítos no sangue dias após a aplicação, nas quatro semanas posteriores não foram encontrados cistos teciduais nos ovinos vacinados. Nos rebanhos ovinos vacinados, houve redução de abortamentos e infecção congênita (Buxton et al., 1993b; Buxton; Innes, 1995). 
Há vários estudos para o desenvolvimento de novas vacinas como prevenção e controle da toxoplasmose nos rebanhos ovinos com a utilização de taquizoítos atenuados (Falcón; Freyre, 2009), antígeno de superfície (Conde et al., 2001) ou pool de antígenos excretores e secretores (Costa et al., 2008), porém, nenhum apresentou boa eficácia. Recentemente, foram desenvolvidas vacinas de DNA do T. gondii (Hiszczyńska-Sawicka et al., 2010a; 2010b; Li et al., 2010), que conferiram resposta imune mais efetiva. No entanto, são necessários outros estudos experimentais e a campo para confirmação da proteção contra o protozoário (Menzies, 2012).

Na prevenção da ocorrência de $T$. gondii em rebanhos ovinos, devem-se adotar procedimentos que visem minimizar ou evitar o contato com a fonte de infecção, ou seja, evitar a contaminação de água e alimentos com fezes dos felinos, restringir acesso desses animais ao ambiente de criação dos ovinos, realizar controle populacional de gatos na propriedade e correto armazenamento de ração e feno. Em caso de abortamento, as medidas preconizadas são a incineração ou o enterro do aborto e das membranas fetais (Dubey, 1994a).

\section{Neospora caninum}

\section{Introdução}

Neospora caninum, agente etiológico da neosporose, é um protozoário formador de cistos teciduais, responsável por falhas reprodutivas em várias espécies animais, inclusive nos ovinos (Jolley, 1999; Lindsay, 1995). Até 1988, era confundido com Toxoplasma gondii, devido a suas similaridades estruturais, porém, as duas espécies são distintas em sua ultraestrutura, imunogenicidade e patogenicidade.

Os primeiros relatos desse parasito referiam-se a cães com sintomatologia neurológica, a qual parecia estar associada a um protozoário com morfologia semelhante a T. gondii (Bjerkas et al., 
1984), porém, anticorpos anti- $T$. gondii não foram detectados no soro desses cães, e a infecção experimental em camundongos não se estabeleceu (Bjerkas; Dubey, 1991). Em 1988, relatos de cães com histórico similar confirmaram que se tratava de um novo parasito (Dubey et al., 1988a) e, quando comparadas a estrutura e antigenicidade dos parasitos de ambos relatos, concluiu-se que se tratava de uma nova espécie (Bjerkas; Dubey, 1991).

N. caninum foi agrupado no filo Apicomplexa, como um novo gênero da família Sarcocystidae (Dubey et al., 1988), juntamente com Toxoplasma, Sarcocystis e Hammondia, após análises sequenciais do DNA ou amplificações sequênciais do RNA, pela técnica de PCR (Holmdahl et al., 1994; Schock et al., 2001)

Após sua descoberta, taquizoítos vivos de N. caninum foram isolados em cultura de células e, a partir destes, a neosporose foi induzida experimentalmente em cães inoculados com taquizoítos e um teste sorológico foi desenvolvido, a RIFI, para detecção de anticorpos anti-N. caninum (Dubey et al., 1988b).

Esse parasita tem emergido como um significante patógeno, acometendo várias espécies de animais domésticos e silvestres. Em algumas regiões, tem sido apontado como uma das maiores causas de abortamento e problemas neuromusculares em cães e animais de produção, principalmente em bovinos (Mayhew et al., 1991; Dubey; De Lahunta, 1993).

\section{Ciclo biológico}

A transmissão transplacentária foi a primeira via relatada experimentalmente (Dubey; Lindsay, 1996); entretanto, em 1998, o ciclo heteroxeno foi elucidado, envolvendo hospedeiros intermediário e definitivo (Figura 57).

Inicialmente, o cão foi identificado como único hospedeiro definitivo de N. caninum (McAllister et al., 1998), posteriormente, os coiotes (Canis latrans) (Gondim et al., 2004), o dingo (Canis lapus dingo) (King et al., 2010), e recentemente os lobos acinzen- 
tados (Canis lapus) (Dubey et al., 2011) também foram reconhecidos como hospedeiros definitivos, ou seja, que eliminam oocistos nas fezes.

Figura 57 - Ciclo biológico de N. caninum

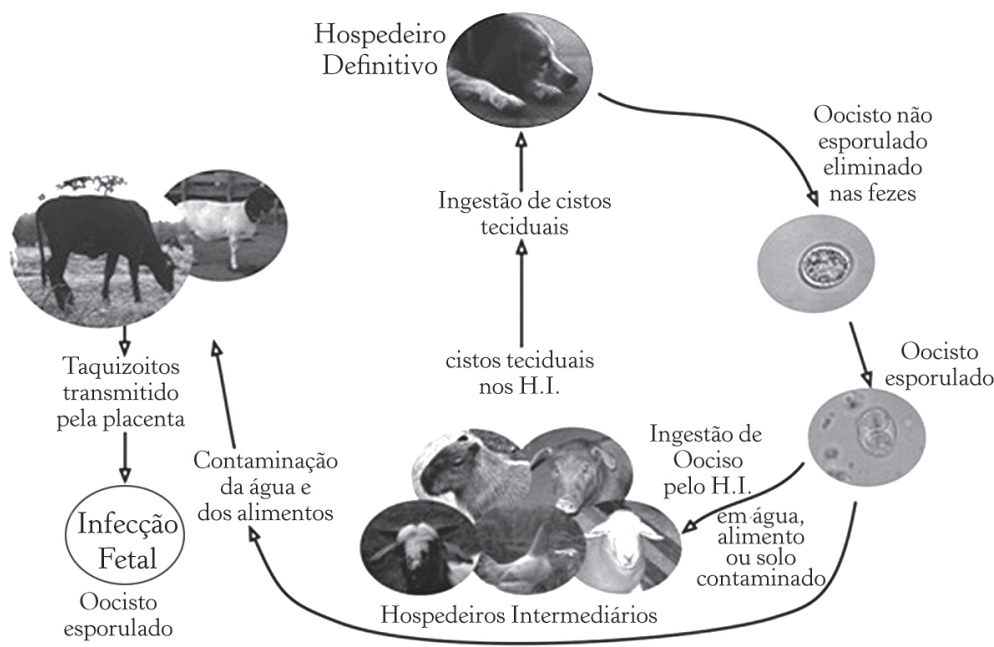

Cães excretam oocistos (Figura 57) cinco ou mais dias após a ingestão de tecidos de animais infectados (Dubey et al., 2007; Pena et al., 2007). A esporulação dos oocistos (Figura 59) ocorre aproximadamente 24 horas após a excreção, dependendo das condições ambientais, como umidade, temperatura e oxigenação (Dubey et al., 2007).

Os três estágios morfológicos reconhecidos do parasito são representados pelos esporocistos, presentes no interior dos oocistos eliminados nas fezes dos cães, e pelos taquizoítos e bradizoítos, contidos nos cistos teciduais (idem, 2002). Os taquizoítos e bradizoítos estão presentes nos hospedeiros intermediários e definitivos, já os oocistos são eliminados somente pelos hospedeiros definitivos (McAllister et al., 1998; Gondim et al., 2004; Dubey et al., 2011). 
Figura 58 - Taquizoítos de N. caninum utilizados na sensibilização de lâminas para detecção de anticorpos anti-N.caninum pela técnica de imunofluorescência indireta

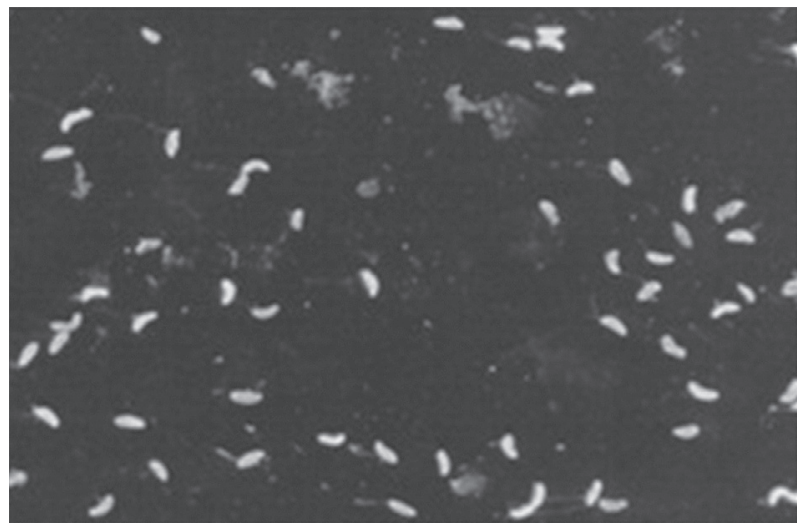

Foto gentilmente cedida por Aline Rezende Rodrigues.

Figura 59 - Oocistos de N. caninum detectados pela técnica de centrífugo-flutuação em solução saturada de sacarose

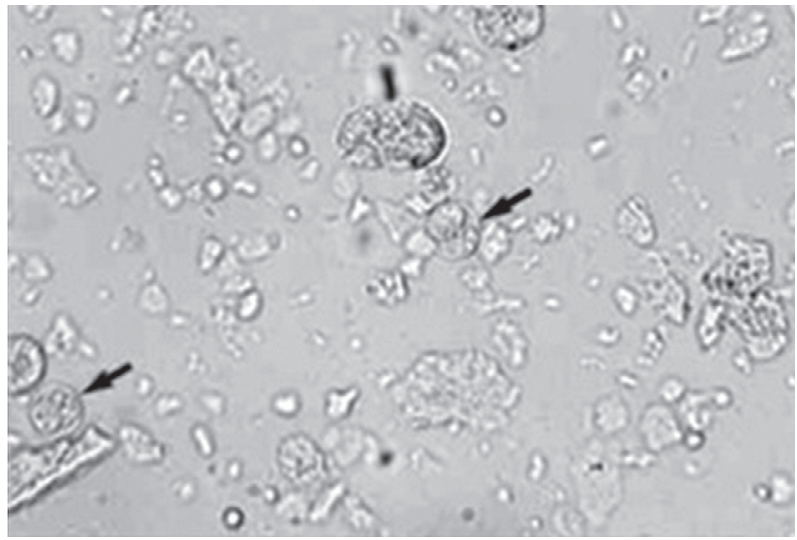

Foto gentilmente cedida por Aline Rezende Rodrigues.

Os taquizoítos apresentam morfologia ovoide, lunar ou globular e medem de $3 \mu \mathrm{m}$ a $7 \mu \mathrm{m}$ x $1 \mu \mathrm{m}$ a $5 \mu \mathrm{m}$ (Figura 58). Em animais infectados, são encontrados principalmente em células neurais, ma- 
crófagos, fibroblastos, endotélio e hepatócitos. Os bradizoítos, que ocorrem no estágio de multiplicação lenta, são circulares ou ovais, com até $107 \mu \mathrm{m}$, apresentam parede lisa com $4 \mu \mathrm{m}$ de espessura e são encontrados encistados principalmente em tecidos neurais, como cérebro, coluna espinhal e retina (Dubey et al., 1988a; 2002; Barr et al., 1991a, 1991b; Dubey; Lindsay, 1996; Speer; Dubey, 1989; Lindsay et al., 1999).

Os hospedeiros definitivos infectam-se ao se alimentarem de tecidos de animais infectados, e os hospedeiros intermediários, como os ovinos, infectam-se pela ingestão de alimentos ou água contaminados por oocistos esporulados. Outra via de infecção é a transplacentária, considerada a principal via de transmissão em animais de produção (Dubey et al., 1998; 2007; Goodswen et al., 2013).

\section{Sinais clínicos}

O principal sinal clínico associado à neosporose é o abortamento, principalmente nos bovinos (López-Gatius et al., 2004; 2005), entretanto, também há relatos de animais infectados que apresentam dificuldade de crescimento, baixo peso ao nascer, ataxia, paresia, exoftalmia, hiperextensão de membros traseiros ou dianteiros (Dubey et al., 1998; Barr et al., 1993; Peters et al., 2001; De Meerschman et al., 2005), além de queda na produtividade leiteira (Romero et al., 2005; Tiwari et al., 2007) e descarte prematuro de animais infectados (Bartels et al., 2006).

Em vacas prenhes, observa-se morte fetal quando a infecção ocorre no início da gestação (Barr et al., 1994; Williams et al., 2007; Rojo-Montejo et al., 2009), abortamentos ou nascimento de animais infectados quando a infecção ocorre no segundo terço (Dubey et al., 1992b; Gondim et al., 2004a; Almería et al., 2010), e no último terço da gestação, comumente nascem animais assintomáticos, porém congenitamente infectados (Williams et al., 2000; Gibney et al., 2008).

Em ovinos, até o momento, há poucos relatos da infecção natural, e os sinais clínicos observados procedem de animais experimen- 
talmente infectados, que apresentaram sinais clínicos e alterações histopatológicas similares às descritas em bovinos (McAllister, 1996). Em ovinos, as lesões fetais assemelham-se às causadas por T. gondii (Dubey, 2010).

Além da produção de anticorpos, ovelhas inoculadas com taquizoítos de N. caninum nos dias 65, 90 e 120 de gestação apresentaram, respectivamente, abortamento, nascimento de cordeiros débeis ou clinicamente normais (McAllister et al., 1996). Sinais clínicos similares também foram observados em infecções naturais (Kobayashi, 2001). Portanto, a gravidade da infecção em ovelhas prenhes pode ser influenciada pelo estágio gestacional (Buxton et al., 1998).

A infecção congênita e o abortamento nem sempre são observados em fêmeas soropositivas. O abortamento geralmente ocorre na primoinfecção, entretanto, ovelhas com infecção crônica também podem abortar nas gestações subsequentes (Jolley, 1999), mas desenvolvem imunidade que confere proteção parcial contra o agente (Buxton et al., 2001).

\section{Diagnóstico}

É difícil determinar a causa do abortamento, entretanto, para auxiliar o diagnóstico da neosporose, além das alterações clínicas e zootécnicas observadas em animais infectados, é recomendada a realização de exames laboratoriais, como sorologia, imunoistoquímica (IHQ), isolamento do agente e PCR (Dubey; Lindsay, 1996).

Exames sorológicos para detecção de anticorpos anti-N. caninum, como a RIFI, o Teste de Aglutinação (NAT) e o ELISA, são de grande importância no diagnóstico (Dubey; Lindsay, 1996; Dubey et al., 2007), principalmente em levantamentos epidemiológicos. A sorologia também pode auxiliar no diagnóstico presuntivo de abortamento pelo protozoário, pela detecção de anticorpos nas fêmeas que abortaram ou em sangue e fluidos corpóreos do feto, porém, não é o diagnóstico mais indicado, devido a relatos de baixa sensibilidade e flutuação de títulos de anticorpos (Barr et al., 1995; 
Wouda et al., 1997; Gottstein et al., 1998; Schock et al., 2000; Álvares-Garcia et al., 2003). Além disso, um resultado negativo não exclui a possibilidade de infecção (Cardoso et al., 2012).

Lesões macroscópicas raramente são observadas. Algumas lesões podem ser encontradas no coração, na musculatura esquelética e no cérebro do feto abortado (Dubey et al., 1998), ou ainda nos cotilédones placentários (Fioretti et al., 2003), porém, a análise é difícil devido à mumificação fetal ou autólise.

Pela análise histológica, cistos podem ser visualizados em tecidos nervosos, porém, o diagnóstico é limitado devido à similaridade morfológica dos cistos de $N$. caninum e $T$. gondii e à pequena quantidade encontrada nos tecidos (Hemphill, 1999; Dubey; Lindsay, 1996). Há relatos de outras lesões menos específicas, como placentite necrosante, encefalite multifocal não supurativa, necrose cerebral, meningite e miosite em amostras fetais (Buxton, 1997; McAllister, 1996).

Para melhorar a especificidade da imunoistoquímica, foi desenvolvido antissoro específico para detecção de taquizoítos e cistos de N. caninum nas amostras teciduais (Cole et al., 1993), mesmo assim, ainda há limitações da técnica (Dubey et al., 2006; Reeit et al., 2007), e a execução e interpretação são difíceis (Hemphill, 1999; Peters et al., 2001).

O isolamento em cultivo celular ou em animais de laboratório também são metodologias utilizadas para confirmar a presença do agente, porém, não são simples (Dubey et al., 1988b; Quinn et al., 2002; Pipano et al., 2002; Rodrigues et al., 2005; Kang et al., 2009). A qualidade do material enviado ao laboratório, como fetos abortados autolisados, além da quantidade insuficiente de parasitos viáveis e inativação devido à decomposição do tecido do hospedeiro, dificultam o isolamento de N. caninum no cultivo celular (Conrad et al., 1993; Dubey; Lindsay, 1996).

Entretanto, melhores resultados são observados no isolamento em animais de laboratório, pois provavelmente cistos teciduais apresentam maior resistência à autólise do que os taquizoítos (Dubey, 2003). Até o momento, não há modelos animais indicados para o 
isolamento do agente. Camundongos knockout são utilizados, porém não são indicados na inoculação de oocistos. Os gerbilos (Meriones unguiculatus) vêm sendo amplamente utilizados em bioensaios e isolamento do agente (Dubey; Lindsay, 2000; Rodrigues et al., 2005).

Para o sorodiagnóstico de N. caninum, duas técnicas principais vêm sendo empregadas: a RIFI (Bjorkman; Uggla, 1999; Ragozo et al., 2003; Figliuolo et al., 2004; Soares et al., 2009; Machado et al., 2011) e o ELISA (Jenkins et al., 1997; Bishop et al., 2011; Pandero et al., 2010).

A técnica da PCR foi incorporada no diagnóstico da neosporose com o objetivo de detectar o DNA do parasita em oocistos, amostras de tecidos e fluidos corpóreos de animais ou fetos infectados (Holmdahl; Mattson, 1996; Kaufmann et al., 1996; Slapeta et al., 2002). A utilização dos métodos moleculares aumentou o limiar de detecção e identificação de N. caninum em amostras teciduais de animais infectados, como placenta ou cérebro (Medina et al., 2006; López-Gatius et al., 2007; Reitt et al., 2007) e ainda permite diferenciar N. caninum de Hammondia heydorni com base nas sequências gênicas do ITS1 (Monteiro et al., 2008).

Recentemente, foi desenvolvida uma PCR-RFLP que propicia diferenciação de oocistos das espécies Hammondia heydorni e $N$. caninum, o que não era possível devido à semelhança morfológica entre os oocistos das duas espécies (Hill et al., 2001; Slapeta et al., 2002), tornando-se uma importante ferramenta no diagnóstico molecular do N. caninum (Monteiro et al., 2008).

\section{Epidemiologia}

A distribuição geográfica de N. caninum é mundial. Recentemente, estudos de prevalência de anticorpos anti- $N$. caninum intensificaram-se, e estes foram descritos em várias espécies de animais silvestres e domésticos (Dubey, 1999; Gondim, 2006; Dubey et al., 2007; de Almeida Cury et al., 2012), inclusive nos ovinos (Figliuolo et al., 2004; Soares et al., 2009; Rossi et al., 2011; Langoni et al., 2011; Moreno et al., 2012). 
O potencial zoonótico desse parasita ainda não é conhecido (Dubey et al., 2007). Apesar da detecção de anticorpos anti-N. caninum em amostras sanguíneas, nenhum caso de neosporose foi relatado em humanos (Tranas et al., 1999; Petersen et al., 1999, McCain, 2008). Por outro lado, o sucesso da transmissão experimental do agente em primatas (Barr et al. 1994) e da infecção de células trofoblásticas em cultivo celular indicam a possibilidade de infecção humana (Carvalho et al., 2010), levantando a questão do potencial zoonótico.

Nos ovinos, N. caninum foi descrito pela primeira vez na Inglaterra em um cordeiro naturalmente infectado pela via transplacentária (Dubey et al., 1990). Posteriormente, vários relatos de infecção natural foram registrados em diversos países (Hassig et al., 2003; Kobayashi et al., 2001; Koyama et al., 2001; Moore, 2005).

Até o momento, ainda há poucos levantamentos epidemiológicos de prevalência do agente na espécie ovina, sendo observadas variações de soropositividade entre 0,45\% (Helmick et al., 2002) e 56,6\% (Abo-Shehada et al., 2010) em estudos realizados em diversos países. No Brasil, anticorpos anti-N. caninum apresentaram variações entre 8\% (Machado et al., 2011) e 65,7\% (Soares et al., 2009) nos inquéritos epidemiológicos em ovinos (Tabela 19).

O primeiro isolado de N. caninum de ovinos naturalmente infectados foi realizado no Japão pela inoculação de tecido cerebral em camundongos imunodeficientes (Koyama et al., 2001). Posteriormente, no Brasil foi obtido o primeiro isolamento do agente pelo bioensaio em cães, procedente de um ovino naturalmente infectado. O cérebro do cordeiro, sem sinais clínicos, com título de anticorpo de 400, foi inoculado via oral em um cão, que, após dez dias, eliminou oocistos. A identificação do isolado teve por base características estruturais, biológicas e moleculares do agente (Pena et al., 2007).

A presença, na propriedade, de canídeos domésticos e silvestres com acesso às instalações e pastagens é considerada importante fator de risco para a transmissão horizontal, pois, quando infectados, eliminam oocistos que contaminam o alimento dos animais 
(Innes et al., 2000; Dubey et al., 2007; Machado et al., 2011). Estudos epidemiológicos também consideram cães da área rural como um fator de risco para o rebanho, pois apresentam maior soropositividade do que cães da área urbana (Wouda et al., 1999; Fernandes et al., 2002; Guimarães Júnior, 2004; Machado et al., 2011).

Há também fatores que afetam a ocorrência de abortamento nos animais, como a dose infectante (Lopez-Gatius et al., 2005; Dubey et al., 2007), quantidade de oocistos ingeridos (Gondim et al., 2004b), período gestacional (Buxton et al., 1998; Kobayashi et al., 2001; Gondim et al., 2004b) e estado imunológico da fêmea (Dubey et al., 2007). Há relatos de possível associação de perda fetal devido ao protozoário em ovinos (Hassig et al., 2003; Howe et al., 2012), porém, até o momento, $N$. caninum não é considerado uma importante causa de abortamento em ovinos (Buxton et al., 1998; Dubey et al., 1990; Dubey; Lindsay, 1990; Helmick et al., 2002).

Tabela 19 - Prevalência de ovinos com anticorpos anti-N. caninum em diferentes regiões do Brasil

\begin{tabular}{l|c|c|c}
\hline \multicolumn{1}{c|}{ Estado } & $\begin{array}{c}\text { Número de } \\
\text { animais }\end{array}$ & \% positivos & Autoria \\
\hline \multirow{2}{*}{ Paraná } & 305 & $9,5^{*}$ & Romanelli et al. (2007) \\
\cline { 2 - 4 } & 381 & $13,9^{*}$ & Munhoz et al. (2010) \\
\cline { 2 - 4 } & 597 & $9,2^{*}$ & Figliuolo et al. (2004) \\
\cline { 2 - 4 } & 382 & $12,8^{*}$ & Langoni et al. (2011) \\
\hline \multirow{2}{*}{ Minas Gerais } & 1.497 & $8^{*}$ & Machado et al. (2011) \\
\cline { 2 - 4 } & 155 & $26,4^{*}$ & Rossi et al. (2011) \\
\cline { 2 - 4 } & 434 & $87,1^{*}$ & Salaberry et al. (2010) \\
\hline Rio Grande do Norte & 409 & $13,4^{*}$ & da Silva Andrade et al. \\
\hline Alagoas & 343 & $1,8^{*}$ & Soares et al. (2009) \\
\hline Distrito Federal & 1.028 & $35,4^{*}$ & Uaria et al. (2010) \\
\hline Roraima & 141 & $29^{*}$ & Aguiar et al. (2004) \\
\hline
\end{tabular}

Método de diagnóstico: * Reaçao de Imunofluorescencia Indireta (RIFI), *** Ensaio Imunoenzimático (ELISA) 


\section{Profilaxia}

Há várias estratégias para prevenção e controle do N. caninum nos rebanhos, como verificar a ocorrência do agente por meio do diagnóstico laboratorial, descarte de animais soropositivos, vacinação e utilização de fármacos.

Em infecções experimentais, o toltrazuril apresentou-se efetivo contra a disseminação de taquizoítos em camundongos (Ammann et al., 2004, Gottstein et al., 2001; Kritzner et al., 2002), porém, estudos recentes demonstraram que o fármaco não apresentou efeito em bradizoítos (Debache et al., 2011). Até o momento, ainda não há relatos de drogas disponíveis para evitar a transmissão do agente da mãe para o feto, portanto, no rebanho, recomenda-se evitar a aquisição de vacas soropositivas, bem como a manutenção no rebanho de bezerros infectados congenitamente. Dessa forma, reduz-se o risco de abortamentos e a possibilidade de transmissão vertical do agente para outras gerações de animais.

Outra medida de prevenção e controle da neosporose nos rebanhos é o abate seletivo dos animais soropositivos (Thurmon; Hietala, 1995, 1996; French et al., 1999), porém, deve ser realizado com cautela, devido à inviabilidade econômica, principalmente se o rebanho apresentar baixa taxa de abortamento (Bartels et al., 2006; Häsler et al., 2006a; Larson et al., 2004; Reichel; Ellis, 2006).

Há vários estudos de produção de vacinas com taquizoítos atenuados (Bartley et al., 2007), doses subletais de taquizoítos vivos (Lundén et al., 2002), taquizoítos vivos irradiados (Ramamoorthy et al., 2006) e antígenos recombinantes (Cannas et al., 2003a; 2003b; Alaeddine et al., 2005; Pinitkiatisakul et al., 2005; 2007; Debache et al., 2009; 2010; Nishikawa et al., 2001a, 2001b; Jenkins et al., 2004). Em camundongos vacinados antes da gestação e desafiados durante a gestação, houve bloqueio da transmissão transplacentária (Nishikawa et al., 2001a; 2001b; Liddell et al., 2003; Jenkins et al., 2004; Haldorson et al., 2005; Debache et al., 2009), bem como ocorreu proteção contra sinais clínicos severos em camundongos 
desafiados com N. caninum atenuados (Lundén et al., 2002; Bartley et al., 2007; Ramamoorthy et al., 2006).

Para bovinos, há uma vacina comercialmente disponível, sendo observada redução na taxa de aborto nas vacas vacinadas em condições de campo, embora a causa dos abortamentos observados e os efeitos dos adjuvantes da vacina não tenham sido determinados (Romero et al., 2004).

Há estudos de vacinas contra neosporose ovina com taquizoítos mortos de $N$. caninum que conferiram proteção parcial contra a transmissão vertical e perda fetal (Jenkins et al., 2004; O'Handley et al., 2003).

Entretanto, a imunidade em ovelhas naturalmente infectadas é, na maioria dos casos, insuficiente para prevenir infecção fetal durante a gestação, porém, o abortamento repetitivo não é frequentemente observado como em bovinos. Isso sugere que o desenvolvimento de vacinas eficazes contra $N$. caninum para prevenir infecção congênita pode ser difícil de ser atingido (Innes et al., 2001).

Para evitar a transmissão horizontal, devido à ingestão de oocistos esporulados, recomenda-se limitar o acesso dos canídeos silvestres e domésticos às pastagens e instalações, para evitar a contaminação de água e alimentos destinados ao consumo dos ovinos. Além disso, recomenda-se enterrar ou incinerar carcaças e restos abortivos e evitar a prática de alimentar os cães com carne crua (Paré et al., 1998; McAllister et al., 1998; Atkinson et al., 2000). Outra medida de prevenção da neosporose é impedir a entrada de animais infectados no rebanho, realizando previamente triagem sorológica de animais adquiridos (Innes et al., 2001; Dubey et al., 2007; Goodswen et al., 2013). Manejos reprodutivos também vêm sendo adotados para reduzir a transmissão transplacentária. Além do controle sanitário das matrizes e de doadores de sêmen, recomenda-se também selecionar receptoras soronegativas, as quais podem gerar animais não infectados mesmo que o embrião implantado proceda de doadoras infectadas (Baillargeon et al., 2001; Landmann et al., 2002; Moskwa et al., 2008). 


\section{Sarcocystis spp.}

\section{Introdução}

Sarcocystis spp. é um protozoário intracelular, agente etiológico da sarcocistose, enfermidade que acomete várias espécies animais, como répteis, peixes, aves e mamíferos. É responsável por perdas econômicas significativas devido ao descarte de carcaças e abortamentos em animais de produção (Tenter, 1995; Borji et al., 2010). O ser humano pode infectar-se por algumas espécies do protozoário, entretanto, nem todas as espécies de Sarcocystis são consideradas zoonoses (Dubey, 1989; Tenter, 1995; Lindsay, 2004).

O primeiro relato de Sarcocystis spp. foi referente a um rato que apresentava cistos brancos filiformes na musculatura estriada, denominados túbulos de Meischeir. Após vinte anos de sua descrição, estruturas semelhantes foram observadas em tecido muscular de suíno. Posteriormente, esse protozoário foi denominado S. meischeriana (Dubey et al., 1989), e desde então várias espécies de Sarcocystis spp. foram descritas e receberam nomeclatura relacionada ao hospedeiro no qual os parasitos foram encontrados.

Após mais de cem anos do primeiro relato do Sarcocystis spp., a ultraestrutura do parasito foi estudada por microscopia eletrônica, e observaram-se estruturas similares às de outros protozoários, como Toxoplasma gondii (Fayer, 2004), sendo agrupado no filo Apicomplexa, classe Sporozoasida, família Sarcocystidae e subfamília Sarcocystinae (Dubey, 1989; Tenter, 1995; Rommel, 1989). O ciclo biológico foi elucidado apenas no início da década de 1970, e todos os estágios evolutivos do gênero Sarcocystis foram esclarecidos por meio da inoculação de bradizoítos em cultivo celular, onde foi possível o desenvolvimento dos estágios sexuais e oocistos (Tenter, 1995). Depois da definição do ciclo de vida do protozoário, outras espécies descritas foram nomeadas de acordo com a estrutura dos cistos e do hospedeiro, porém, o formato e o tamanho dos cistos podem variar com o tempo de infecção e a célula parasitada (Dubey, 1989).

Entre as inúmeras espécies descritas, há quatro que acometem os ovinos - S. medusiformis e S. ovifelis (ou S. gigantea), trans- 
mitidas pelos felídeos, e S. ovicanis (ou S. tenella) e S. arieticanis, transmitidas pelos cães. Entre as espécies de Sarcocystis que infectam os ovinos, as mais patogênicas são as transmitidas pelos cães, principalmente S. tenella (Dubey, 1989; Tenter, 1995; Lindsay, 2004). Recentemente, os ovinos também foram considerados como possível hospedeiro intermediário da espécie S. capracanis, após a detecção de merozoítos pela PCR em fluído cérebro-espinal de ovelhas naturalmente infectadas que apresentavam sintomatologia nervosa. Essa espécie é comumente transmitida pelos cães e muito frequentemente observada em caprinos (Formisano et al., 2013).

\section{Ciclo biológico}

Sarcocystis spp. é heteroxeno obrigatório, necessitando da participação de hospedeiro carnívoro ou onívoro para completar o ciclo de vida (Lindsay et al., 1995; Fayer, 2004). O esquema do ciclo biológico está apresentado na Figura 60. Os estágios morfológicos do protozoário são: (1) oocistos contendo dois esporocistos com quatro espozoítos no interior, eliminado nas fezes dos hospedeiros definitivos; (2) merontes presentes no endotélio vascular; e (3) sarcocistos, que são cistos teciduais envolvendo os bradizoítos no seu interior (Tenter, 1995; Dubey; Lindsay, 2006; Lindsay, 2004).

Os ovinos infectam-se ao ingerir oocistos esporulados ou esporocistos eliminados nas fezes dos hospedeiros definitivos (cães e gatos). Posteriormente à liberação dos esporozoítos, o parasito atravessa a parede do intestino delgado e penetra nas células endoteliais, multiplica-se por merogonia ou esporogonia, evoluindo para merontes primários, iniciando a fase assexuada do ciclo biológico. Após maturação dos merontes primários, merozoítos liberados no fluxo sanguíneo migram para arteríolas, capilares, veias e vênulas, para desenvolvimento das gerações subsequentes, que parasitam capilares sanguíneos de vários órgãos dos hospedeiros, ocorrendo finalmente o desenvolvimento em bradizoítos e formação dos cistos teciduais ou sarcocistos (Figura 61), forma infectante para os hospedeiros definitivos (Fayer, 2004; Domenis et al., 2011). 
Figura 60 - Ciclo biológico do Sarcocystis spp.

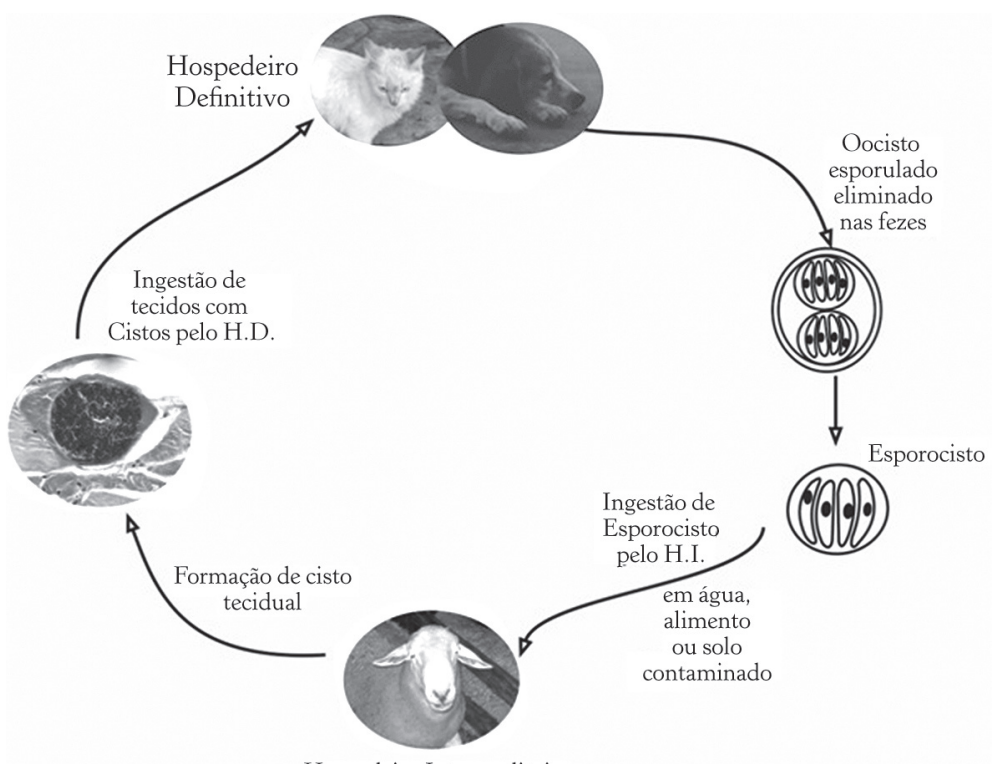

Hospedeiro Intermediário

Figura 61 - Cisto de Sarcocystis spp. indicado pela seta em corte histológico pela técnica de Hematoxilina e Eosina

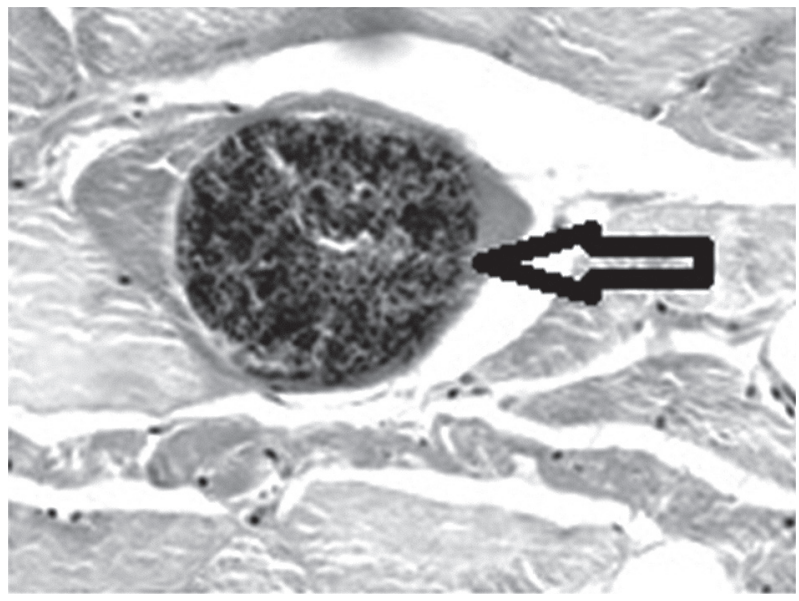


A fase sexuada do ciclo ocorre nos hospedeiros definitivos, que se infectam após ingestão de cistos presentes no tecido muscular dos ovinos. Após a liberação dos bradizoítos no intestino delgado, há a diferenciação em macrogameta e microgametas, que, após a fecundação, originam os oocistos esporulados, contendo dois esporocistos, os quais, após atingirem o lúmen intestinal, são eliminados juntamente com as fezes, contaminando o meio ambiente (Dubey; Lindsay, 2006; Domenis et al., 2011; Fayer, 2004).

\section{Sinais clínicos}

A maioria das infecções nos ovinos é assintomática, porém, animais infectados com grande quantidade de esporocistos ou por espécies patogênicas de Sarcocystis podem apresentar febre, anemia, retardo no crescimento, anorexia, perda de peso, distúrbios de coagulação sanguínea (Fayer et al., 1975; Buxton, 1998; Dubey, 1989; Dubey; Lindsay, 2006), claudicação ou andar rígido e diarreia. A sintomatologia nervosa, como convulsões, cegueira e alterações na atividade motora, pode ocorrer devido à penetração do parasito no tecido cerebral ou pela obstrução do fluxo sanguíneo (Pugh, 2004).

Em infecções experimentais, a primeira geração de merogonia, aparentemente, não é patogênica para ovinos, causando apenas aumento da temperatura corpórea, não ocorrendo sintomatologia nem morte (Leek et al., 1977, Dubey; Lindsay, 2006). Os sinais clínicos ocorrem durante o desenvolvimento de merontes maduros de segunda geração no endotélio vascular, principalmente dos rins e do cérebro (Dubey et al., 1989; Herbert; Smith, 1987).

Há relatos de sinais nervosos, como ataxia, paresia (Dubey, 1989; O'Toole et al., 1993), fraqueza dos membros posteriores, tetraparesia evoluindo para o óbito do animal (Jeffrey et al., 1988), abortamentos e natimortos (Uggla; Buxton, 1990; Mackie et al., 1992, Dubey; Lindsay, 2006; Pescador et al., 2007). A miopatia aguda é outro sinal clínico reportado em ovelhas com infecção por Sarcocystis (Jeffrey et al., 1988). Em infecção experimental, a gravidade dos sinais clínicos é dose-dependente, no entanto, animais 
infectados com doses elevadas de esporocistos de S. tenella apresentaram sintomatologia severa e abortamento (O'Donoghue; Wilkinson, 1988).

Recentemente, foram relatados casos de sarcocistose em ovelhas devido a possível infecção com a espécie $S$. capracanis. Os animais apresentaram sintomatologia nervosa como ataxia, hiperestesia e dorsiflexão do pescoço, além de alterações hematológicas e bioquímicas indicando danos musculares (Formisano et al., 2013). Apesar de os cordeiros infectados serem mais susceptíveis, fêmeas gestantes também apresentam maior sensibilidade à infecção (Fayer et al., 1988; Dubey; Lindsay, 2006; Pescador et al., 2007), havendo falhas reprodutivas aproximadamente quatro semanas após a infecção (Pugh, 2004). No início da gestação, geralmente ocorre reabsorção ou morte fetal e abortamento no final gestacional, porém, o mecanismo de abortamento devido ao Sarcocystis spp. ainda é desconhecido (Mackie et al., 1992). Raramente é detectado o parasito na placenta ou no feto (Herbert; Smith, 1987).

A infecção da fêmea nas últimas semanas de prenhez pode causar distúrbios metabólicos, como toxemia gestacional, entretanto, quando o abortamento não ocorre, o cordeiro pode apresentar-se fraco, com baixo peso corpóreo e retardo no crescimento (Smith, 1987; Smith et al., 1988).

\section{Diagnóstico}

Os hospedeiros definitivos (cães e gatos) geralmente não apresentam sintomatologia, portanto, para o diagnóstico, recomenda-se utilizar técnicas copropasitológicas para detectar oocistos ou esporocistos nas fezes. O diagnóstico de sarcocistose ou de abortamento pelo protozoário em animais de produção não é simples. Nos ovinos, o diagnóstico pela observação dos sinais clínicos apresentados é muito difícil devido à inespecificidade da sintomatologia na fase aguda, no entanto, recomenda-se a utilização de diagnósticos laboratoriais (Dubey, 1989; Tenter, 1995; Lindsay, 2004). O diagnóstico da infecção post mortem é baseado em achados patológicos 
como hemorragias na musculatura esquelética, cardíaca e da língua, ou ainda encefalite hemorrágica e gliose focal (Leek et al., 1977; Tenter, 1995). A visualização de cistos macroscópicos nos tecidos é preconizada na inspeção da carcaça, porém, nem sempre é possível, devido à pequena quantidade aparente (Herbert; Smith, 1987; Pugh, 2005). Em abortamentos, podem ser observadas alterações hemorrágicas e necrose focal nos placentomas maternos, contudo, nos tecidos fetais não são encontradas lesões, e dificilmente o agente é encontrado (Uggla; Buxton, 1990).

A utilização de técnicas histológicas possibilita a observação de cistos em cortes, principalmente em musculatura do coração, da língua e do tecido cerebral e renal, contudo, não é possível diferenciar morfologicamente a espécie de Sarcocystis envolvida na infecção (Dubey et al., 1989; Uggla; Buxton, 1990). Para aumentar a sensibilidade e especificidade do diagnóstico histológico, foram desenvolvidos métodos imunoistoquímicos (Uggla; Buxton, 1990; Hamir et al., 1993), porém, podem ocorrer reações cruzadas entre as várias espécies de Sarcocystis spp. (Burgess, et al., 1988; O’Donoghuee; Weyreter, 1984), ou ainda com outros protozoários como, Toxoplasma gondii e Neospora caninum (Tenter, 1995). Pela digestão péptica dos tecidos, é possível avaliar os bradizoítos após liberação dos sarcocistos, entretanto, a identificação das espécies é limitada devido à semelhança morfológica das espécies de Sarcocystis spp. O isolamento em cultivo celular é outra metodologia preconizada, principalmente em estudos da biologia do parasito e manutenção do agente para uso como ferramenta para fins diagnósticos (Dubey, 1989; Lindsay et al., 1995; Müller et al., 2013).

$\mathrm{Na}$ inspeção post mortem, macro e microcistos podem ser detectados em vários órgãos como esôfago, diafragma, coração, língua e musculatura esquelética (Beyazit et al., 2007; Adriana et al., 2008; Dehaghi et al., 2013). Os macrocistos são detectados principalmente no esôfago, na musculatura intercostal e no diafragma, e com menor frequência do que os microcistos (Fukuyo et al., 2002; Daryani et al., 2006; Dehaghi et al., 2013), sugerindo que a detecção macroscópica apresenta menor sensibilidade diagnóstica (Dehaghi 
et al., 2013). Vale ressaltar que as espécies $S$. ovifelis e $S$. medusiformis desenvolvem quantidades maiores de macrocistos, enquanto $S$. tenella e S. arieticanis, de microcistos (Dubey et al., 1989a).

Ruminantes, suínos, roedores, cães e gatos podem ser utilizados como modelo experimental para isolamento e estudos da biologia e patogenia do Sarcocystis spp. (Lindsay et al., 1995; Adriana et al., 2008). Entretanto, técnicas de isolamento não são indicadas para diagnóstico de abortos devido à ausência do parasito em fetos abortados (Dubey, 1989; Tenter, 1995).

Para detecção de anticorpos, métodos sorológicos como a RIFI (Tenter, 1988; Uggla et al., 1987) e ELISA (Gasbarre et al., 1984; O’Donoghue; Weyreter, 1984; Smith; Herbert, 1986; Tenter, 1988) são indicados, auxiliando o diagnóstico da infecção e estudos epidemiológicos (Dubey, 1989; Tenter, 1995; Lindsay, 2004), porém, sua utilização é limitada devido a possíveis reações cruzadas entre as espécies de Sarcocystis spp. (Dubey, 1989; Lindsay, 2004) e dificuldade de detecção da resposta imune do hospedeiro na primeira fase de merogonia (Uggla; Buxton, 1990; Buxton, 1998).

Recentemente, o diagnóstico molecular vem sendo intensamente utilizado para determinar a diversidade genética em estudos de taxonomia filogenética e mapeamento epidemiológico (Erlich et al., 1991; Tenter, 1995; Mugridge et al., 2000; Adriana et al., 2008; Domenis et al., 2011; Prakas et al., 2011). Várias técnicas de biologia molecular, como a PCR e suas variantes, são utilizadas, apresentando rapidez e sensibilidade diagnóstica (Erlich et al., 1991; Formisiano et al., 2013). A PCR-RFLP é amplamente utilizada e considerada como método molecular rápido, pouco dispendioso e acurado para discriminar diferentes protozoários, bem como Sarcocystis spp. (Ellis et al., 1995; Heckeroth; Tenter, 1999; Motamedi et al., 2011, Hamidinejat et al., 2014; Formisiano et al., 2013).

\section{Epidemiologia}

Até o momento, não existem evidências de que as espécies de Sarcocystis que acometem os ovinos sejam capazes de infectar 
humanos (Dubey, 1989; Lindsay, 2004; Dubey; Lindsay, 2006). As perdas econômicas não se restringem apenas a problemas reprodutivos, mas também são devidas à condenação de carcaças em abatedouros devido à presença de cistos teciduais (Borji et al., 2010). Apesar de poucos estudos de prevalência do Sarcocystis spp. em ovinos, há relatos de ocorrência em várias partes do mundo (Fukuyo et al., 2002; Ozkayhan et al., 2007; Beyazit et al., 2007; Daryani et al., 2006; Silva et al., 2009; Dehaghi et al., 2013), com elevados índices de ocorrência do agente nos rebanhos ovinos (Tabela 20).

Tabela 20 - Ocorrência de Sarcocystis spp. em ovinos

\begin{tabular}{l|c|c|c|c}
\hline Origem & Animais & $\%$ macrocistos & $\%$ microcistos & Autoria \\
\hline Mongólia & 777 & - & $96,7 \#$ & Fukuyo et al. (2002) \\
\hline Turquia & \multicolumn{5}{|l}{} \\
\hline - Kirikkale & 112 & 58,92 & $47,3^{*}$ & Ozkayhan et al. (2007) \\
\hline - Izmir & 200 & 24,5 & $86,5^{*}$ & Beyazit et al. (2007) \\
\hline Romênia & 48 & 26,3 & $91,7^{*} *$ & Adriana et al. (2008) \\
\hline Iran & \multicolumn{5}{|l}{} \\
\hline - Arbadil & 2.110 & 33,93 & - & Daryani et al. (2006) \\
\hline - Kerman & 450 & $6 \%$ & - & Dehaghi et al. (2013) \\
\hline & 112 & - & $100 \#$ & Dehaghi et al. (2013)
\end{tabular}

Diagnóstico *histológico, **com triquinoscópio ou \#esmagamento tecidual entre lâminas.

Há fatores que favorecem a elevada prevalência do agente, como o envolvimento de vários hospedeiros definitivos na transmissão, imunidade que não impede reinfecções com reeliminação de oocistos, grande quantidade de oocistos excretados - independentemente do número de cistos teciduais ingeridos e na eliminação nas fezes da forma infectante, que não necessitam de condições ambientais adequadas para a esporulação - e resistência elevada dos esporocistos que permanecem nas pastagens por tempo prolongado (Dubey, 1988; Dubey; Lindsay, 2006).

No Brasil, há relatos de infecção experimental (Pacheco et al., 1995; Botelho; Pacheco, 1996) e de infecção natural (Pescador et 
al., 2007), entretanto, apenas recentemente houve a primeira descrição de S. tenella em dois ovinos no Brasil (Silva et al., 2011). Os animais assintomáticos eram procedentes dos estados do Rio Grande do Sul e de São Paulo. Apesar de apresentarem anticorpos anti-T. gondii, o isolamento pelo bioensaio em camundongos foi negativo. Pela PCR-RFLP, obtiveram-se produtos sugestivos de parasitos apicomplexa, e pelo sequenciamento do RNA ribossômico 18S, foi possível identificar a ocorrência da espécie S. tenella em ambos os animais (ibidem).

Não há diferenças de susceptibilidade à infecção com relação a sexo e raça, porém, em ovinos mais velhos, acima de um ano de idade, a ocorrência de cistos teciduais apresenta-se significantemente maior do que em cordeiros (Abo-Shehada et al., 1996; O'Zkayhan et al., 2007; Beyazit et al., 2007).

\section{Prevenção e controle}

Para o tratamento de animais que apresentam a fase clínica da doença, é sugerida a quimioprofilaxia com salinomicina, monensina ou amprólio (Fayer et al, 1975; Pugh, 2004). Não há vacinas comercialmente disponíveis, porém, há relatos de que animais imunizados experimentalmente com baixa dosagem de esporocistos atenuados podem apresentar certa imunidade (Ford, 1985; Abdel-Baki et al., 2009), com produção de cistos teciduais inviáveis de tamanho reduzido, além de apresentaram resposta imune, sugerindo uma possível proteção contra o protozoário (Abdel-Baki et al., 2009). Entretanto, a imunidade adquirida é mantida por pouco tempo, não sendo eficaz na proteção a longo prazo (O’Donoghue; Wilkinson, 1988).

Para prevenção e controle efetivo, é necessário interromper o ciclo de transmissão do parasito, principalmente reduzindo a contaminação ambiental por oocistos eliminados pelos hospedeiros definitivos. Portanto, recomenda-se primeiramente impedir a ingestão de carne crua pelos carnívoros susceptíveis e enterrar ou incinerar carcaças de animais mortos. Deve-se evitar que cães e gatos tenham acesso à água e aos alimentos fornecidos aos ovinos 
e deve-se restringir o acesso desses animais aos locais de criação (Dubey, 1989; Tenter, 1995; Fayer, 2004,). Porém, essas medidas são de difícil implementação, especialmente em rebanhos em que o manejo inclui o auxílio de cães (Pugh, 2004).

\section{Referências bibliográficas}

\section{Toxoplasma gondii}

BLACK, M. W.; BOOTHROYD, J. C. Lyfe Cycle of Toxoplasma gondii. Microbiol. Mol. Biol. Rev., [s. 1.], v.64, p.607-23, 2000.

BONAMETTI, A. M. et al. Surto de toxoplasmose aguda transmitida através da ingestão de carne crua de gado ovino. Rev. Soc. Bras. Med. Trop., [s. 1.], v.30, p.21-5, 1997.

BUXTON, D.; THOMSON, K. M.; MALEY, S. Treatment of Ovine Toxoplasmosis with a Combination of Sulphamezathine and Pyrimethamine. Vet. Rec., [s. 1.], v.132, p.409-11, 1993a.

; INNES, E. A. A Commercial Vaccine for Ovine Toxoplasmosis. Parasitology, [s. 1.], v.110, p.11-6, 1995.

et al. Experimental Challenge of Sheep 18 Months After Vaccination with a Live (S48) Toxoplasma gondii Vaccine. Vet. Rec., [s. 1.], v.133, p.310-2, $1993 \mathrm{~b}$.

et al. Toxoplasma gondii and Ovine Toxoplasmosis: New Aspects of an Old Story. Vet. Parasitol., [s. 1.], v.149, p.25-8, 2007a.

et al. Ovine Toxoplasmosis: Transmission, Clinical Outcome and Control. Parasitologia, [s. 1.], v.49, p.219-21, 2007b.

CHIARI, C. de A.; NEVES, D. P. Toxoplasmose Humana Adquirida Através da Ingestão de Leite de Cabra. Mem. Inst. Oswaldo Cruz, [s. 1.], v.79, p.337-40, 1984.

CONDE, M. et al. Analysis of IgG Response to Experimental Infection with RH Toxoplasma gondii in Goats. Comp. Immunol. Microbiol. Infect. Dis., [s. 1.], v.24, p.197-206, 2001.

COSTA, K. S. et al. Chickens (Gallus domesticus) are Natural Intermediate Hosts of Neospora caninum. Int. J. Parasitol., [s. 1.], v.38, p.157-9, 2008. COUTO, F. A. A. Dimensionamento do mercado de carne ovina e caprina no Brasil. In: CNPq. Apoio à cadeia produtiva da ovinocaprinocultura brasileira. Relatório final. Brasília: [s. n.], p.10-5, 2001. 
CRISTINA, N. et al. Restriciton-Fragment-Length-Polymorphisms among Toxoplasma gondii Strains. Parasitol. Res., [s. 1.], v.77, p.266-8, 1991.

DARDÉ, M. L.; BOUTEILLE, B.; PESTRE-ALEXANDRE, M. Isoenzyme Analysis of 36 Toxoplasma gondii Isolates: Biological and Epidemiological Implications. J. Parasitol., [s. 1.], v.78, p.786-94, 1992.

DE SILVA, L. M.; MULCAHY, D.; KAMATH, R. A Family Outbreak of Toxoplasmosis: A Serendipitous Finding. J. Infect., [s. 1.], v.8, p.163-7, 1984.

DUBEY, J. P. Persistence of Encysted Toxoplasma gondii in Caprine Livers and Public Health Significance of Toxoplasmosis in Goats. J. Am. Vet. Med. Assoc., [s. 1.], v.177, p.1203-7, 1980.

. Toxoplasmosis in Cat. Feline Pract., [s. 1.], v.16, p.12-45, 1986.

. Toxoplasmosis in Goats: A Review. Agri-Practice, [s. 1.], v.8, p.43-62, 1987.

. Toxoplasmosis. J. Am. Vet. Med. Assoc., [s. 1.], v.205, p.1593-8, 1994a.

. Toxoplasmosis. J. Am. Vet. Med. Assoc., [s. 1.], v.206, p.1693-8, 1994b.

Toxoplasmosis, Sarcocystosis, Isosporosis, and Cyclosporosis. In: PALMER, S. R.; SOULSBY, E. J. L., SIMPSON, D. J. H. (eds.). Zoonoses. Oxford: Oxford University Press, 1998a, p.679-97.

. Toxoplasmosis of Animals and Humans. Boca Raton: CRC Press, 2010.313p.

; BEATTIE, C. P. Toxoplasmosis of Animals and Man. Boca Raton: CRC Press, 1988, p.40.

; KIRKBRIDE, C. A. Epizootics of Ovine Abortion Due to Toxoplasma gondii in North Central United States. J. Am. Vet. Med. Assoc., [s. 1.], v.184, p.657-60, 1984.

;_ Toxoplasmosis and Other Causes of Abortions in Sheep from North Central United States. J. Am. Vet. Med. Assoc., [s. 1.], v.196, p.287-90, 1990.

et al. Biological and Genetic Characterization of Toxoplasma gondii Isolates from Chickens (Gallus domesticus) from São Paulo, Brazil: Unexpected Findings. Int. J. Parasitol., [s. 1.], v.32, p.99-106, 2002.

et al. Toxoplasmosis in Humans and Animals in Brazil: High Prevalence, High Burden of Disease, and Epidemiology. Parasitology, [s. 1.], v.139, p.1375-424, 2012. 
DUNCANSON, P. et al. High Levels of Congenital Transmission of Toxoplasma gondii in a Commercial Sheep Flock. Int. J. Parasitol., [s. 1.], v.31, p.1699-703, 2001.

ESTEBAN-REDONDO, I.; INNES, E. A. Toxoplasma gondii Infection in Sheep and Cattle. Comp. Immunol. Microbiol. Infect. Dis., [s. 1.], v.20, p.191-6, 1997.

et al. Detection of T. gondii in Tissues of Sheep and Cattle Following Oral Infection. Vet. Parasitol., [s. 1.], v.86, p.1555-71,1999.

FALCÓN, J.; FREYRE, A. Toxoplasma gondii: Prototype Immunization of Lambs Against Formation of Muscle and Brain Cysts. Vet. Parasitol., [s. 1.], v.166, p.15-20, 2009.

FREYRE, A. et al. The Incidence and Economic Significance of Ovine Toxoplasmosis in Uruguay. Vet. Parasitol., [s. 1.], v.81, p.85-8, 1999.

GUTIERREZ, J. et al. Application of Quantitative Real-Time Polymerase Chain Reaction for the Diagnosis of Toxoplasmosis and Enzootic Abortion of Ewes. J. Vet. Diagn. Invest., [s. 1.], v.24, p.846-54, 2012.

HILL, D.; DUBEY, J. P. Toxoplasma gondii: Transmission, Diagnosis and Prevention. Clin. Microbiol. Infect., [s. 1.], v.8, p.634-40, 2002.

HISZCZYŃSKA-SAWICKA, E. et al. The Immune Responses of Sheep After DNA Immunization with, Toxoplasma gondii MAG1 Antigen-with and without Co-Expression of Ovine Interleukin 6. Vet. Immunol. Immunopathol., [s. 1.], v.136, p.324-9, 2010a.

et al. Comparison of Immune Response in Sheep Immunized with DNA Vaccine Encoding Toxoplasma gondii GRA7 Antigen in Different Adjuvant Formulations. Exp. Parasitol., [s. 1.], v.124, p.365-72, 2010b.

HOWE, D. K.; SIBLEY, L. D. Toxoplasma gondii Comprises Three Clonal Lineages: Correlation of Parasite Genotype with Human Disease. J. Infect. Dis., [s. 1.], v.172, p.1561-6, 1995.

IBGE, 2013. Banco de dados agregados. Disponível em: <http://www. sidra.ibge.gov.br/bda/pecua/default.asp? $\mathrm{t}=2 \& \mathrm{z}=\mathrm{t} \& \mathrm{o}=20 \& \mathrm{u} 1=1 \& \mathrm{u}$ $2=1 \& \mathrm{u} 3=1 \& \mathrm{u} 4=1 \& \mathrm{u} 5=16=1>$. Acesso em: 10 maio 2013.

INNES, E. A. Toxoplasmosis: Comparative Species Susceptibility and Host Immune Response. Comp. Immunol. Microbiol. Infect. Dis., [s. 1.], v.20, p.131-8, 1997.

; VERMEULEN, A. N. Vaccination as a Control Strategy Against the Coccidial Parasites Eimeria, Toxoplasma and Neospora. Parasitology, [s. 1.], v.133, p.145-68, 2006. 

2009.

et al. Ovine Toxoplasmosis. Parasitology, [s. 1.], v.136, p.1887-94,

JURÁNKOVÁ, J. et al. Quantification of Toxoplasma gondii in Tissue Samples of Experimentally Infected Goats by Magnetic Capture and Real-Time PCR. Vet. Parasitol., [s. 1.], v.193, p.95-9, 2013.

LEHMANN, T. et al. Globalization and the Population Structure of Toxoplasma gondii. Proc. Natl. Acad. Sci. U. S. A., [s. 1.], v.103, p.1143-8, 2006.

LI, B. et al. Immunological Response of Sheep to Injections of Plasmids encoding Toxoplasma gondii SAG1 and ROP1 Genes. Parasite Immunol., [s. 1.], v.32, p.671-83, 2010.

LOPES, W. D. et al. Semen Variables of Sheep (Ovis aries) Experimentally Infected with Toxoplasma gondii. Anim. Reprod. Sci., v.111, p.312-9, 2009.

et al. Sexual Transmission of Toxoplasma gondii in Sheep. Vet. Parasitol., [s. 1.], v.195, p.47-56, 2013.

MAINAR, R. C. et al. Prevalence of Agglutinating Antibodies to Toxoplasma gondii in Small Ruminants of the Madrid Region, Spain, and Identification of Factors Influencing Seropositivity by Multivariate Analysis. Vet. Res. Commun., [s. 1.], v. 20, p.163-9, 1996.

MAINARDI, R. S. et al. Seroprevalence of Toxoplasma gondii in Dairy Goats in the São Paulo State, Brazil. Rev. Soc. Bras. Med. Trop., [s. 1.], v.36, p.759-61, 2003.

MARCA, M. C. et al. Comparison of Indirect Immunofluorescent Antibody Test and Modified Direct Agglutination Test Methods for Detection of Toxoplasma gondii Antibodies in Adult Sheep in Spain. Vet. Parasitol., [s. 1.], v.67, p.99-103, 1996.

MENZIES, P. I. Vaccination Programs for Reproductive Disorders of Small Ruminants. Anim. Reprod. Sci., [s. 1.], v.130, p.162-72, 2012.

MUGRIDGE, N. B. et al. Phylogenetic Analysis Based on Full-Length Large Subunit Ribosomal RNA Gene Sequence Comparison Reveals that Neospora caninum is More Closely Related to Hammondia heydorni than to Toxoplasma gondii. Int. J. Parasitol., [s. 1.], v.29, p.1545-56, 1999.

OWEN, M. R.; TREES, A. J. Acute Phase Toxoplasma Abortions in Sheep. Vet. Rec., [s. 1.], v.142, p.480-2, 1998.

PENA, H. F. et al. Population Structure and Mouse-Virulence of Toxoplasma gondii in Brazil. Int. J. Parasitol., [s. 1.], v.38, p.561-9, 2008. et al. PCR-RFLP Genotyping of Toxoplasma gondii from Chickens from Espírito Santo State, Southeast Region, Brazil: New Geno- 
types and a New SAG3 Marker Allele. Vet. Parasitol., [s. 1.], v.323, p. 530-3, 2013.

PUGH, D. G. Clínica de ovinos e caprinos. São Paulo: Roca, 2004. 528p.

RAGOZO, A. M. et al. Seroprevalence and Isolation of Toxoplasma gondii from Sheep from São Paulo State, Brazil. J. Parasitol., [s. 1.], v.94, p.1259-63, 2008.

ROMANELLI, P. R. et al. Prevalence of Neospora caninum and Toxoplasma gondii in Sheep and Dogs from Guarapuava Farms, Paraná State, Brazil. Res. Vet. Sci., v.82, p.202-7, 2007.

SACKS, J. J.; ROBERTO, R. R.; BROOKS, N. F. Toxoplasmosis Infection Associated with Raw Goat's Milk. J. Am. Med. Assoc., [s. 1.], v.248, p.1728-32, 1982.

SANTANA, L. F. et al. Detection of Toxoplasma gondii in the Reproductive System of Male Goats. Rev. Bras. Parasitol. Vet., [s. 1.], v.19, p.179-82, 2010.

SIBLEY, L. D.; BOOTHROYD, J. C. Virulent Strains of Toxoplasma gondii Comprise a Single Clonal Lineage. Nature, [s. 1.], v.359, p.82-5, 1992.

SOARES, R. M. et al. Genotyping of Toxoplasma gondii Isolates from Free Range Chickens in the Pantanal Area of Brazil. Vet. Parasitol., [s. 1.], v.178, p.29-34, 2011.

TENTER, A. M.; HECKEROTH, A. R.; WEISS, L. M. Toxoplasma gondii: from Animals to Humans. Int. J. Parasitol., [s. 1.], v.30, p.121768, 2000.

VAUGHAN, L. Abortion in Sheep. Comp. Cont. Educ. Pract., [s. 1.], v.49, p.170-4, 1996.

VITOR, R. W. A.; PINTO, J. B.; CHIARI, C. A. Eliminação de Toxoplasma gondii através de urina, saliva e leite de caprinos experimentalmente infectados. Arq. Bras. Med. Vet. Zoot., [s. 1.], v.43, p.147-54, 1991.

WALSH, C. P. et al. Survival of Toxoplasma gondii Tachyzoites in Goat Milk: Potential Source of Human Toxoplasmosis. J. Euk. Microbiol., [s. 1.], v.46, p.73S-4S, 1999.

YAI, L. E. et al. Genetic Diversity Among Capybara (Hydrochaeris hydrochaeris) Isolates of Toxoplasma gondii from Brazil. Vet. Parasitol., [s. 1.], v.162, p.332-7, 2009.

\section{Neospora caninum}

ABO-SHEHADA, M. N.; ABU-HALAWEH, M. M. Flock-level Seroprevalence and Risk Factors for Neospora caninum Among Sheep and Goats in Northern Jordan. Prev. Vet. Med., [s. 1.], v.93, p.25-32, 2010. 
AGUIAR, D. M. et al. Prevalência de anticorpos anti-Neospora caninum em ovinos do município de Monte Negro, RO, Amazônia Ocidental brasileira. Arq. Inst. Biol., [s. 1.], v.71, p.616-8, 2004.

ALAEDDINE, F. et al. Reduced Infection and Protection from Clinical Signs of Cerebral Neosporosis in C57BL/6 Mice Vaccinated with Recombinant Microneme Antigen NCMIC. J. Parasitol., [s. 1.], v.91, p.657-65, 2005.

ALMERÍA, S. et al. Fetal Death in Cows Experimentally Infected with Neospora caninum at 110 Days of Gestation. Vet. Parasitol., [s. 1.], v.169, p.304-11, 2010.

ÁLVAREZ-GARCÍA, G. et al. Influence of Age and Purpose for Testing on the Cut-Off Selection of Serological Methods in Bovine Neosporosis. Vet. Res., [s. 1.], v.34, p.341-52, 2003.

AMMANN, P. et al. The Role of B- and T-Cell Immunity in Toltrazuril- Treated C57BL/6 WT, MicroMT and Nude Mice Experimentally Infected with Neospora caninum. Parasitol. Res., [s. 1.], v.93, p.178-87, 2004.

ATKINSON, R. A. et al. Seroprevalence of Neospora caninum Infection Following an Abortion Outbreak in a Dairy Cattle Herd. Aust. Vet. J., v.78, p.262-6, 2000.

BAILLARGEON, P. et al. Evaluation of the Embryo Transfer Procedure Proposed by the International Embryo Transfer Society as a Method of Controlling Vertical Transmission of Neospora caninum in cattle. J. Am. Vet. Med. Assoc., [s. 1.], v.218, p.1803-6, 2001.

BARR, B. C. et al. Neospora-like Protozoal Infections Associated with Bovine Abortions. Vet. Pathol., [s. 1.], v.28, p.110-6, 1991a.

et al. Neospora-like Encephalomyelitis in a Calf: Pathology, Ultrastructure and Immunoreactivity. J. Vet. Diag. Invest., [s. 1.], v.3, p.39-46, 1991b.

et al. Congenital Neospora Infection in Calves Born from Cows that Had Previously Aborted Neospora-Infected Fetuses: Four Cases (1990-1992). J. Am. Vet. Med. Assoc., [s. 1.], v.202, p.113-7, 1993.

et al. Experimental Reproduction of Bovine Fetal Neospora Infection and Death with a Bovine Neospora Isolate. J. Vet. Diag. Invest., [s. 1.], v.6, p.207-15, 1994.

et al. Diagnosis of Bovine Fetal Neospora Infection with an Indirect Fluorescent Antibody Test. Vet. Rec., [s. 1.], v.137, p.611-3, 1995.

BARTELS, C. J. M. et al. Effect of Neospora caninum-Sero Status on Culling, Reproductive Performance and Milk Production in Dutch 
Dairy Herds with and without a History of Neospora caninum-Associated Abortion Epidemics. Prev. Vet. Med., [s. 1.], v.77, p.186-98, 2006.

BARTLEY, P. M. et al. Inoculation of Balb/c Mice with Live Attenuated Tachyzoites Protects Against a Lethal Challenge of Neospora caninum. Parasitology, [s. 1.], v.135, p.13-21, 2008.

BISHOP, S. et al. The First Report of Ovine Cerebral Neosporosis and Evaluation of Neospora caninum Prevalence in Sheep in New South Wales. Vet. Parasitol., [s. 1.], v.170, p.137-42, 2011.

BJERKÅS, I.; DUBEY, J. P. Evidence that Neospora caninum is Identical to the Toxoplasma-Like Parasite of Norwegian Dogs. Acta Vet. Scandin., [s. 1.], v.32, p.407-10, 1991.

; MOHN, S. F.; PRESTHUS, J. Unidentified Cyst-Forming Sporozoon Causing Encephalomyelitis and Myositis in Dogs. Z. Parasitenkd., [s. 1.], v.70, p.271-4, 1984.

BUXTON, D. et al. Experimental Infection of Non-Pregnant and Pregnant Sheep with Neospora caninum. J. Comp. Pathol., [s. 1.], v.117, p.1-16, 1997.

et al. The Pathogenesis of Experimental Neosporosis in Pregnant Sheep. J. Comp. Pathol., [s. 1.], v.118, p.267-79, 1998.

et al. Immunity to Experimental Neosporosis in Pregnant Sheep. Parasite Immunol., [s. 1.], v.23, p.85-91, 2001.

CANNAS, A. et al. Vaccination of Mice Against Experimental Neospora caninum Infection Using NcSAG1- and NcSRS2-Based Recombinant Antigens and DNA Vaccines. Parasitology, [s. 1.], v.126, p.303-12, 2003a. et al. Reduced Cerebral Infection of Neospora caninum Infected Mice After Vaccination with Recombinant Microneme Protein NcMIC3 and RIBI Adjuvant. J. Parasitol., [s. 1.], v.89, p.44-50, 2003b.

CARDOSO, J. M. et al. A Longitudinal Study of Neospora caninum Infection on Three Dairy Farms in Brazil. Vet. Parasitol., [s. 1.], v.187, p. 553-7, 2012.

CARVALHO, J. V. et al. Differential Susceptibility of Human Trophoblastic (BeWo) and Uterine Cervical (HeLa) Cells to Neospora caninum Infection. Int. J. Parasitol., [s. 1.], v.40, p.1629-37, 2010.

COLE, R. A. et al. Detection of Neospora caninum in Tissue Sections Using a Murine Monoclonal Antibody. Vet. Diagn. Invest., [s. 1.], v.5, p.579-84, 1993.

CONRAD, P. A. et al. In Vitro Isolation and Characterization of a Neospora sp. from Aborted Bovine Foetuses. PARASITOLOGY, v.106, p.239-249, 1993. 
DA SILVA ANDRADE, G. et al. Seroprevalence and Risk Factors for Neospora caninum in Sheep in the State Minas Gerais, Southeastern Brazil. Vet. Parasitol., [s. 1.], v.188, p.168-71, 2012.

DE ALMEIDA CURI, N. H. et al. Pathogens of Wild Maned Wolves (Chrysocyon brachyurus) in Brazil. J. Wildl. Dis., [s. 1.], v.48, p.1052-6, 2012.

DEBACHE, K. et al. Vaccination with Recombinant NcROP2 Combined with Recombinant NcMIC1 and NcMIC3 Reduces Cerebral Infection and Vertical Transmission in Mice Experimentally Infected with Neospora caninum Tachyzoites. Int. J. Parasitol., [s. 1.], v.39, p.137384, 2009.

et al. Intraperitoneal and Intra-Nasal Vaccination of Mice with Three Distinct Recombinant Neospora caninum Antigens Results in Differential Effects with Regard to Protection Against Experimental Challenge with Neospora caninum Tachyzoites. Parasitology, [s. 1.], v.137, p.229-40, 2010.

et al. Experimental Treatment of Neospora caninum-Infected Mice with the Arylimidamide DB750 and the Thiazolide Nitazoxanide. Exp. Parasitol., [s. 1.], v.129, p.95-100, 2011.

DE MEERSCHMAN, F. et al. Clinical, Pathological and Diagnostic Aspects of Congenital Neosporosis in a Series of Naturally Infected Calves. Vet. Rec., v.157, p.115-8, 2005.

DUBEY, J. P. Recent Advances in Neospora and Neosporosis. Vet. Parasitol., [s. 1.], v.84, p.349-67, 1999.

. Neosporosis in Cattle. J. Parasitol., [s. 1.], v.89, p.S42-S56, 2003.

. Toxoplasmosis of Animals and Humans. Boca Raton: CRC Press, 2010.313p.

; KOESTNER, A.; PIPER, R. C. Repeated Transplacental Transmission of Neospora caninum in Dogs. J. Am. Vet. Med. Assoc., [s. 1.], v.197, p.857-60, 1990.

; LINDSAY, D. S. Neospora caninum Induced Abortion in Sheep. J. Vet. Diagn. Invest., [s. 1.], v.2, p.230-3,1990.

; DE LAHUNTA, A. Neosporosis Associated Congenital Limb Deformities in a Calf. Appl. Parasitol., [s. 1.], v.34, p.229-33, 1993.

; LINDSAY, D. S. A Review of Neospora caninum and Neosporosis. Vet. Parasitol., [s. 1.], v.67, p.1-59, 1996.

; LINDSAY, D. S. Gerbils (Meriones unguiculatus) are Highly Susceptible to Oral Infection with Neospora caninum Oocysts. Parasitol. Res., [s. 1.], v.86, p.165-8, 2000. 
; SCHARES, G. Diagnosis of Bovine Neosporosis. Vet. Parasitol., [s. 1.], v.140 p.1-34, 2006.

; ORTEGA-MORA, L. M. Epidemiology and Control of Neosporosis and Neospora caninum. Clin. Microbiol. Rev., [s. 1.], v.20, p.323-67, 2007.

et al. Newly Recognized Fatal Protozoan Disease of Dogs. J. Vet. Med. Assoc., [s. 1.], v.192, p.1269-85, 1988a.

et al. Neonatal Neospora caninum Infection in Dogs: Isolation of the Causative Agent Experimental Transmission. J. Am. Med. Assoc., [s. 1.], v.193, p.1259-63, 1988b.

et al. Fatal Congenital Neospora caninum Infection in a Lamb. J. Parasitol., [s. 1.], v.76, p.127-30, 1990.

et al. Induced Transplacental Transmission of Neospora caninum in Cattle. J. Am. Vet. Med. Assoc., [s. 1.], v.201, p.709-13, 1992.

et al. Hydrocephalus Associated with Neospora caninum-Infection in an Aborted Bovine Fetus. J. Comp. Pathol., [s. 1.], v.118, p.169-73, 1998.

et al. Redescription of Neospora caninum and its Differentiation from Related Coccidia. Int. J. Parasitol., [s. 1.], v.32, p.929-46, 2002. et al. Gray Wolf (Canis lupus) is a Natural Definitive Host for Neospora caninum. Vet. Parasitol., [s. 1.], v.181, p.382-7, 2011.

FARIA, E. B. et al. Risk Factors Associated with Neospora caninum Seropositivity in Sheep from the State of Alagoas, in the Northeast Region of Brazil. J. Parasitol., [s. 1.], v.96, p.197-9, 2010.

FERNANDES, B. C. et al. Prevalence of Anti-Neospora caninum Antibodies in Dogs from Urban, Periurban and Rural Areas of the city of Uberlândia, Minas Gerais-Brazil. Vet. Parasitol., [s. 1.], v.13, p.33-40, 2004.

FIGLIUOLO, L. P. C. et al. Prevalence of Anti-Toxoplasma gondii and Anti-Neospora caninum Antibodies in Ovine from São Paulo State. Vet. Parasitol., v.123, p.161-6, 2004.

FIORETTI, D. P. et al. Neospora caninum Infection and Congenital Transmission: Serological and Parasitological Study of Cows up to the Fourth Gestation. J. Vet. Med. B, v.50, p.399-404, 2003.

FRENCH, N. P. et al. Mathematical Models of Neospora caninum Infection in Dairy Cattle: Transmission and Options for Control. Int. J. Parasitol., [s. 1.], v.29, p.1691-704, 1999.

GIBNEY, E. H. et al. The Extent of Parasite-Associated Necrosis in the Placenta and Foetal Tissues of Cattle Following N. caninum Infection 
in Early and Late Gestation Correlates with Foetal Death. Int. J. Parasitol., [s. 1.], v.38, p.579-88, 2008.

GONDIM, L. F. P. et al. Coyotes (Canis latrans) are Definitive Hosts of Neospora caninum. Int. J. Parasitol., [s. 1.], v.34, p.159-61, 2004.

et al. Transplacental Transmission and Abortion in Cows Administered Neospora caninum Oocysts. J. Parasitol., [s. 1.], v.90, p.1394400, 2004a.

et al. Transplacental Transmission and Abortion in Cows Administered Neospora caninum Oocysts. J. Parasitol., [s. 1.], v.90, p.1394400, 2004b.

GONDIM, L. F. P. Neospora caninum in Wildlife. Trends Parasitol., [s. 1.], v.22, p.247-52, 2006.

GOODSWEN, S. J.; KENNEDY, P. J.; ELLIS, J. T. A Review of the Infection, Genetics, and Evolution of Neospora caninum: From the Past to the Present. Infect. Genet. Evol., [s. 1.], v.13, p.133-50, 2013.

GOTTSTEIN, B. et al. Molecular and Immunodiagnostic Investigations on Bovine Neosporosis in Switzerland. Int. J. Parasitol., [s. 1.], v.28, p.679-91, 1998.

et al. Efficacy of Toltrazuril and Ponazuril Against Experimental Neospora caninum Infection in Mice. Parasitol. Res., [s. 1.], v.87, p.438, 2001.

GUIMARÃES JR., J. S. et al. Prevalence of Neospora caninum and Factors Associated with Their Presence in Dairy Cattle of the North of Paraná State, Brazil. Vet. Parasitol., v.124, p.1-8, 2004.

HALDORSON, G. J. et al. Immunization with Native Surface Protein NcSRS2 Induces a Th2 Immune Response and Reduces Congenital Neospora caninum Transmission in Mice. Int. J. Parasitol., [s. 1.], v.35, p.1407-15, 2005.

HÄSLER, B. et al. Financial Analysis of Various Strategies for the Control of Neospora caninum in a Dairy Cattle in Switzerland. Prev. Vet. Med., [s. 1.], v.77, p. 230-53, 2006a.

et al. Simulating the Impact of Four Control Strategies on the Population Dynamics of Neospora caninum Infection in Swiss Dairy Cattle. Prev. Vet. Med., [s. 1.], v.77, p.254-83, 2006b.

HÄSSIG, M. et al. Neospora caninum in Sheep: a Herd Case Report. Vet. Parasitol., [s. 1.], v.117, p.213-20, 2003.

HELMICK, B. et al. Serological Investigation of Aborted Sheep and Pigs for Infection by Neospora caninum. Res. Vet. Sci., [s. 1.], v.73, p.187-9, 2002. 
HEMPHILL, A. The Host-Parasite Relationship in Neosporosis. Adv. Parasitol., [s. 1.], v.43, p.47-104, 1999.

HILL, D. E. et al. Specific Detection of Neospora caninum Oocysts in Fecal Samples from Experimentally-Infected Dogs Using the Polymerase Chain Reaction. J. Parasitol., v.87, p.395-8, 2001.

HOLMDAHL, O. J; MATTSSON, J. G. Rapid and Sensitive Identification of Neospora caninum by in vitro Amplification of the Internal Transcribed Spacer. Parasitology, [s. 1.], v.112, p.177-82, 1996.

et al. The Phylogeny of Neospora caninum and Toxoplasma gondii Based on Ribosomal RNA Sequences. FEMS Microbiol. Letters, [s. 1.], v.119, p.187-92, 1994.

HOWE, L. et al. Potential Involvement of Neospora caninum in Naturally Occurring Ovine Abortions in New Zealand. Vet. Parasitol., [s. 1.], v.185, p.64-71, 2012.

INNES, E. A. et al. Neosporosis. Aspects of Epidemiology and Host Immune Response. Ann. N. Y. Acad. Sci., [s. 1.], v.916, p.93-101, 2000. et al. Protection Against Vertical Transmission in Bovine Neosporosis. Int. J. Parasitol., [s. 1.], v.31, p.1523-34, 2001.

JENKINS, M. C.; Wouda, W.; Dubey, J.P. Serological response over time to recombinant Neospora caninum antigens in cattle after a neosporosis-induced abortion. Clin. Diag. Lab. Immunol., v.4, p.270-274, 1997.

JENKINS, M. C.; TUO, W.; DUBEY, J. P. Evaluation of Vaccination with Neospora caninum Protein for Prevention of Fetal Loss Associated with Experimentally Induced Neosporosis in Sheep. Am. J. Vet. Res., [s. 1.], v.65, p.1404-8, 2004.

JOLLEY, W. R. et al. Repetitive Abortion in Neospora-Infected Ewes. Vet. Parasitol., [s. 1.], v.82, p.251-7, 1999.

KANG, S. W. et al. Characterization of Tissue Distribution and Histopathological Lesions in Neospora caninum Experimentally Infected Gerbils. Parasitol. Res., v.104, p.1261-8, 2009.

KAUFMANN, H. et al. Discrimination of Neospora caninum from Toxoplasma gondii and Other Apicomplexan Parasites by Hybridization and PCR. Mol. Cell. Probes, [s. 1.], v.10, p.289-97, 1996.

KING, J. S. et al. Australian Dingoes are Definitive Hosts of Neospora caninum. Int. J. Parasitol., [s. 1.], v.40, p.945-50, 2010.

KOBAYASHI, Y. et al. Naturally-Occurring Neospora caninum Infection in an Adult Sheep and Her Twin Fetuses. J. Parasitol., [s. 1.], v.87, p.434-6, 2001. 
KOYAMA, T. et al. Isolation of Neospora caninum from the Brain of a Pregnant Sheep. J. Parasitol., [s. 1.], v.87, p.1486-8, 2001.

KRITZNER, S. et al. An Explorative Study to Assess the Efficacy of Toltrazuril-Sulfone (Ponazuril) in Calves Experimentally Infected with Neospora caninum. Ann. Clin. Microbiol. Antimicrob., [s. 1.], v.1, p.4, 2002.

LANDMANN, J. K. et al. Confirmation of the Prevention of Vertical Transmission of Neospora caninum in Cattle by the Use of Embryo Transfer. Aust. Vet. J., [s. 1.], v.80, p.502-3, 2002.

LANGONI, H. et al. Serological Profile of Toxoplasma gondii and Neospora caninum Infection in Commercial Sheep from São Paulo State, Brazil. Vet. Parasitol., [s. 1.], v.177, p.50-4, 2011.

LARSON, R. L.; HARDIN, D. K.; PIERCE, V. L. Economic Considerations for Diagnostic and Control Options for Neospora caninum-Induced Abortions in Endemically Infected Herds of Beef Cattle. J. Am. Vet. Med. Assoc., [s. 1.], v.224, p.1597-604, 2004.

LIDDELL, S. et al. Immunization of Mice with Plasmid DNA Coding for NcGRA7 or NcsHSP33 Confers Partial Protection Against Vertical Transmission of Neospora caninum. J. Parasitol., [s. 1.], v.89, p.496500, 2003.

LINDSAY, D. S.; UPTON, S. J.; DUBEY, J. P. A Structural Study of the Neospora caninum Oocyst. Int. J. Parasitol., [s. 1.], v.29, p.1521-3, 1999.

LÓPEZ-GATIUS, F.; PABÓN, M.; ALMERÍA, S. Neospora caninum Infection does not Affect Early Pregnancy in Dairy Cattle. Theriogenology, [s. 1.], v.62, p. 606-13, 2004. ; SANTOLARIA, P.; . Neospora caninum Infection does not Affect the Fertility of Dairy Cows in Herds with High Incidence of Neospora-Associated Abortions. J. Vet. Med. B, v.52, p.51-53, 2005.

et al. Protection Against Abortion Linked to Gamma Interferon Production in Pregnant Dairy Cows Naturally Infected with Neospora caninum. Theriogenology, [s. 1.], v.68, p.1067-73, 2007.

LUNDÉN, A. et al. Immunisation of Mice Against Neosporosis. Int. J. Parasitol., [s. 1.], v.32, p.867-76, 2002.

MACHADO, G. P. et al. Seroprevalence and Risk Factors Associated with Neosporosis in Sheep and Dogs from Farms. Vet. Parasitol., [s. 1.], v.182, p.356-8, 2011.

MAYHEW, I. G. et al. Treatment of Encephalomyelitis Due to Neospora caninum in a Litter of Puppies. J. Small Anim. Pract., [s. 1.], v.32, p.609-12, 1991. 
MCALLISTER, M. M. et al. Evidence Suggesting a Point Source Exposure in an Outbreak of Bovine Abortion Due to Neosporosis. J. Vet. Diag. Invest., [s. 1.], v.8, p.355-7, 1996a.

et al. Experimental Neosporosis in Pregnant Ewes and Their Offspring. Vet. Pathol., [s. 1.], v.33, p.647-55, 1996.

et al. Dogs Are Definitive Hosts of Neospora caninum. Int. J. Parasitol., [s. 1.], v.28, p.1473-8, 1998.

MCCANN, C. M. et al. Lack of Serologic Evidence of Neospora caninum in Humans, England. Emerg. Infect. Dis., [s. 1.], v.14, p.978-80, 2008.

MEDINA, L. et al. Survey of Neospora caninum Infection by Nested PCR in Aborted Fetuses from Dairy Farms in Aguascalientes, Mexico. Vet. Parasitol., [s. 1.], v.136, p.187-91, 2006.

MONTEIRO, R. M. et al. Differential Diagnosis of Oocysts of Hammondia-Like Organisms of Dogs and Cats by PCR-RFLP Analysis of 70-Kilodalton Heat Shock Protein (HSP70) Gene. Parasitol. Res., [s. 1.], v.103, p.235-8, 2008.

MOORE, D. P. Neosporosis in South America. Vet. Parasitol., [s. 1.], v.127, p.87-97, 2005.

MORENO, B. et al. Occurrence of Neospora caninum and Toxoplasma gondii Infections in Ovine and Caprine Abortions. Vet. Parasitol., [s. 1.], v.187, p.312-8, 2012.

MOSKWA, B. et al. Studies on Neospora caninum DNA Detection in the Oocytes and Embryos Collected from Infected Cows. Vet. Parasitol., [s. 1.], v.158, p.370-5, 2008.

MUNHOZ, K. F. et al. Occurrence of Anti-Neospora caninum Antibodies in Sheep from Farms Located in Northern Paraná, Brazil. Semina, [s. 1.], v.31, p.1031-40, 2010.

NISHIKAWA, Y. et al. Protective Efficacy of Vaccination by Recombinant Vaccinia Virus Against Neospora caninum Infection. Vaccine, [s. 1.], v.19, p.1381-90, 2001a.

et al. Interferon-Gamma-Induced Apoptosis in Host Cells Infected with Neospora caninum. Parasitology, v.123, p.25-31, 2001b.

O'HANDLEY, R. M. et al. Vaccination of Ewes for Prevention of Vertical Transmission of Neospora caninum. Am. J. Vet. Res., [s. 1.], v.64, p.44952, 2003.

PANDERO, R. et al. Seroprevalence of Toxoplasma gondii and Neospora caninum in Wild and Domestic Ruminants Sharing Pastures in Galicia (Northwest Spain). Res. Vet. Sci., [s. 1.], v.88, p.111-5, 2010.

PARÉ, J. et al. Seroepidemiologic Study of Neospora caninum in Dairy Herds. J. Am. Vet. Med. Assoc., [s. 1.], v.213, p.1595-8, 1998. 
PENA, H. F. et al. Isolation and Molecular Detection of Neospora caninum from Naturally Infected Sheep from Brazil. Vet. Parasitol., [s. 1.], v.147, p.61-6, 2007.

PETERS, M. et al. Immunohistochemical and Ultrastructural Evidence for Neospora caninum Tissue Cysts in Skeletal Muscles of Naturally Infected Dogs and Cattle. Int. J.Parasitol., [s. 1.], v.31, p.1144-8, 2001. PETERSEN, E. et al. Neospora caninum Infection and Repeated Abortions in Humans. Emerg. Infect. Dis., [s. 1.], v.5, p.278-80, 1999.

PINITKIATISAKUL, S. et al. Immunisation of Mice Against Neosporosis with Recombinant NcSRS2 Iscoms. Vet. Parasitol., [s. 1.], v.129, p.25-34, 2005.

et al. Immunogenicity and Protective Effect Against Murine Cerebral Neosporosis of Recombinant NcSRS2 in Different Iscom Formulations. Vaccine, [s. 1.], v.25, p.3658-68, 2007.

PIPANO, E. et al. Susceptibility of Psammomys obesus and Meriones tristrami to Tachyzoites of Neospora caninum. J. Parasitol., [s. 1.], v.88, p.314-9, 2002.

QUINN, H. E. et al. Characterisation of an Outbred Pregnant Mouse Model of Neospora caninum Infection. J. Parasitol., [s. 1.], v.88, p.6916, 2002.

RAGOZO, A. M. A. et al. Ocorrência de Anticorpos Anti-Neospora caninum em Soros de Bovinos Procedentes de Seis Estados Brasileiros. Rev. Bras. Parasit. Vet., [s. 1.], v.12, p.33-7, 2003.

RAMAMOORTHY, S. et al. Vaccination with Gamma-Irradiated Neospora caninum Tachyzoites Protects Mice Against Acute Challenge with N. caninum. J. Eukaryot. Microbiol.,[s. 1.], v.53, p.151-6, 2006.

REICHEL, M. P.; ELLIS, J. T. If Control of Neospora caninum Infections is Technically Feasible does it Make Economic Sense? Vet. Parasitol., [s. 1.], v.142, p.23-34, 2006.

REITT, K. et al. Aetiology of Bovine Abortion in Switzerland from 1986 to 1995 - A Retrospective Study with Emphasis on Detection of Neospora caninum and Toxoplasma gondii by PCR. J. Vet. Med. A, [s. 1.], v.54, p.15-22, 2007.

RODRIGUES, A. A. et al. Serological Responses to Neospora caninum in Experimentally and Naturally Infected Water Buffaloes (Bubalus bubalis). Vet. Parasitol., [s. 1.], v.129, p.21-4, 2005.

ROJO-MONTEJO, S. et al. Isolation and Characterization of a Bovine Isolate of Neospora caninum with Low Virulence. Vet. Parasitol., [s. 1.], v.159, p.7-16, 2009. 
ROMANELLI, P. R. et al. Prevalence of Neospora caninum and Toxoplasma gondii in Sheep and Dogs from Guarapuava Farms, Paraná State, Brazil. Res. Vet. Sci., [s. 1.], v.82, p.202-7, 2007.

ROMERO, J. J.; PÉREZ, E.; FRANKENA, K. Effect of a Killed Whole Neospora caninum Tachyzoite Vaccine on the Crude Abortion Rate of Costa Rican Dairy Cows Under Field Conditions. Vet. Parasitol., [s. 1.], v.123, p.149-59, 2004.

et al. Effect of Neosporosis on Productive and Reproductive Performance of Dairy Cattle in Costa Rica. Theriogenology, [s. 1.], v.64, p.1928-39, 2005.

ROSSI, G. F. et al. Evaluation of Toxoplasma gondii and Neospora caninum Infections in Sheep from Uberlândia, Minas Gerais State, Brazil, by Different Serological Methods. Vet. Parasitol., [s. 1.], v.175, p.252-9, 2011.

SALABERRY, S. R. et al. Prevalence of Neospora caninum Antibodies in Sheep Flocks of Uberlândia County, MG. Rev. Bras. Parasitol. Vet., [s. 1.], v.19, p.148-51, 2010.

SCHOCK, A. et al. Histopathological Survey of Aborted Bovine Fetuses in Scotland with Specia1 Reference to Neospora caninum. Vet. Rec., [s. 1.], v.147, p.687-88, 2000.

et al. Genetic and Biological Diversity Among Isolates of Neospora caninum. Parasitology, [s. 1.], v.123, p.13-23, 2001.

SLAPETA, J. R. et al. Coprodiagnosis of Hammondia heydorni in Dogs by PCR Based Amplification of ITS $1 \mathrm{rRNA}$ : Differentiation from Morphologically Indistinguishable Oocysts of Neospora caninum. Vet. J., [s. 1.], v.163, p.147-54, 2002.

SOARES, H. S. et al. Prevalence of Anti-Toxoplasma gondii and Anti- Neospora caninum Antibodies in Sheep from Mossoró, Rio Grande do Norte, Brazil. Vet. Parasitol., [s. 1.], v.160, p. 211-4, 2009.

SPEER, C. A.; DUBEY, J. P. Ultrastructure of Tachyzoites, Bradyzoites, and Tissue Cysts of Neospora caninum. J. Protozool., [s. 1.], v.36, p.45863, 1989.

THURMOND, M. C.; HIETALA, S. K. Culling Associated with Neospora caninum Infection in Dairy Cows. Am. J. Vet. Res., [s. 1.], v.57, p.1559-62, 1996.

TIWARI, A. et al. Production Effects of Pathogens Causing Bovine Leukosis, Bovine Viral Diarrhea, Paratuberculosis, and Neosporosis. J. Dairy Sci., [s. 1.], v.90, p.659-69, 2007. 
TRANAS, J. et al. Serological Evidence of Human Infection with the Protozoan Neospora caninum. Clin. Diagn. Lab. Immunol., [s. 1.], v.6, p.765-7, 1999.

UENO, T. E. et al. Prevalence of Toxoplasma gondii and Neospora caninum Infections in Sheep from Federal District, Central Region of Brazil. Trop. Anim. Health Prod., [s. 1.], v.4, p.547-52, 2009.

WILLIAMS, D. J. L. et al. Neospora caninum-Associated Abortion in Cattle: The Time of Experimentally-Induced Parasitaemia During Gestation Determines Foetal Survival. Parasitology, [s. 1.], v.121, p.347-58, 2000.

et al. Immunization of Cattle with Live Tachyzoites of Neospora caninum Confers Protection Against Fetal Death. Infect. Immun., [s. 1.], v.75, p.1343-8, 2007.

WOUDA, W.; DUBEY, J. P.; JENKINS, M. C. Serological Diagnosis of Bovine Fetal Neosporosis. J. Parasitol., [s. 1.], v.83, p.545-7, 1997. et al. Seroepidemiological Evidence for a Relationship Between Neospora caninum Infections in Dogs and Cattle. Int. J. Parasitol., [s. 1.], v.29, p.1677-88, 1999.

\section{Sarcocystis spp.}

ABDEL-BAKI, A. A. et al. Lambs Infected with Uv-Attenuated Sporocysts of Sarcocystis ovicanis Produced Abnormal Sarcocysts and Induced Protective Immunity Against a Challenge Infection. Korean J. Parasitol., [s. 1.], v.47, p.131-8, 2009.

ABO-SHEHADA, M. N. Age: Variations in the Prevalence of Sarcocystosis in Sheep and Goats from Northern and Central Jordan. Prev. Vet. Med., [s. 1.], v.27, p.135-40, 1996.

ADRIANA, T. et al. Epidemiology and Etiology in Sheep Sarcocystosis. Bull. UASVM Vet. Med., [s. 1.], v.65, p.49-54, 2008.

BEYAZIT, A.; YAZICIOĞLU, Ö.; KARAER, Z. The Prevalence of Ovine Sarcocystis Species in Izmir Province. Ankara Üniv. Vet. Fak. Derg, [s. 1.], v.54, p.111-6, 2007.

BORJI, H.; PARANDEH, S. The Abattoir Condemnation of Meat Because of Parasitic Infection, and its Economic Importance: Results of a Retrospective Study in North-Eastern Iran. Ann. Trop. Med. Parasitol., [s. 1.], v.104, p.641-7, 2010.

BOTELHO, G. G.; PACHECO, R. G. Aspectos bioquímicos e riscos na infecção experimental de ovinos com Sarcocystis tenella (Railliet, 1886) 
Moulé., 1986 (Apicomplexa: Sacocystidae). Rev. Bras. Med. Vet., [s. 1.], v.18, p.26-31, 1996.

BURGESS, D. E.; SPEER, C. A.; REDUKER, D. W. Identification of Antigens of Sarcocystis cruzi Sporozoites, Merozoites, and Bradyzoites with Monoclonal Antibodies. J. Parasitol., [s. 1.], v.74, p.828-32,1988.

BUXTON, D. Protozoan Infections (Toxoplasma gondii, Neospora caninum and Sarcocystis spp.) in Sheep and Goats: Recent Advances. Vet. Res., [s. 1.], v.29, p.289-310, 1998.

DARYANI, A. et al. Survey of Sarcocystis Infection in Slaughtered Sheep and Buffaloes in Ardabil, Iran. J. Anim. Vet. Adv., [s. 1.], v.5, p.60-2, 2006.

DEHAGHI, M. M. et al. Survey of Sarcocystis Infection in Slaughtered Sheep in Kerman Abattoir, Kerman, Iran. Comp. Clin. Pathol., [s. 1.], v.22, p.343-6, 2013.

DOMENIS, L. et al. Detection of a Morphogenetically Novel Sarcocystis hominis-Like in the Context of a Prevalence Study in Semi-Intensively Bred Cattle in Italy. Parasitol. Res., [s. 1.], v.109, p.1677-87, 2011.

DUBEY, J. P.; SPEER, C. A.; FAYER, R. Sarcocystis of Animals and Man. Boca Raton: CRC Press, 1989. 215p.

; LINDSAY, D. S. Neosporosis, Toxoplasmosis, and Sarcocystosis in Ruminants. Vet. Clin. Food Anim., [s. 1.], v. 22, p.645-71, 2006.

et al. Ovine Sporozoan Encephalomyelitis Linked to Sarcocystis Infection. Vet. Parasitol., [s. 1.], v.34, p.159-63, 1989.

ELLIS, J. T. et al. Phylogenetic Relationships Between Toxoplasma and Sarcocystis Deduced from a Comparison of $18 \mathrm{~S}$ rDNA Sequences. Parasitology, [s. 1.], v.110, p.521-8, 1995.

ERLICH, H. A.; GELFAND, D.; SNINSKY, J. J. Recent Advances in the Polymerase Chain Reaction. Science, [s. 1.], v.252, p.1643-51, 1991.

FAYER, R. Sarcocystis spp. in Human Infections. Clin. Microbiol. Rev., [s. 1., v.4, p.894-902, 2004.

; JOHNSON, A. J. Effect of Amprolium on Acute Sarcocystosis in Experimentally Infected Calves. J. Parasitol., [s. 1.], v.61, p.932-6, 1975.

; DUBEY, J. P. Sarcocystis Induced Abortion and Fetal Death. Prog. Clin. Biol. Res., [s. 1.], v.281, p.153-64, 1988.

FORD, G. E. Immunity of Sheep to Homologous Challenge with Dog-Borne Sarcocystis Species Following Varying Levels of Prior Exposure. Int. J. Parasitol., [s. 1.], v.15, p.629-34, 1985. 
FORMISANO, P. et al. Identification of Sarcocystis capracanis in Cerebrospinal Fluid from Sheep with Neurological Disease. Vet. Parasitol., [s. 1.], v.193, p.252-5, 2013.

FUKUYO, M.; BATTSETSEG, G.; BYAMBAA, B. Prevalence of Sarcocystis Infection in Meat-Producing Animals in Mongolia. Southeast Asian J. Trop. Med. Public Health, [s. 1.], v.33, p.490-5, 2002.

GASBARRE, L. C.; SUTER, P.; FAYER, R. Humoral and Cellular Immune Responses in Cattle and Sheep Inoculated with Sarcocystis. Am. J. Vet. Res., [s. 1.], v.45, p.1592-6, 1984.

HAMIDINEJAT, H. et al. Molecular Detection of Sarcocystis Species in Slaughtered Sheep by PCR-RFLP from South-Western of Iran. J. Parasitol. Dis., 2014.

HAMIR, A. N. et al. Immunohistochemical Study to Demonstrate Sarcocystis neurona in Equine Protozoal Myeloencephalitis. J. Vet. Diagn. Invest., [s. 1.], v.5, p.418-22, 1993.

HECKEROTH, A. R.; TENTER, A. M. Development and Validation of Species-Specific Nested PCRs for Diagnosis of Acute Sarcocystosis in Sheep. Int. J. Parasitol., [s. 1.], v.29, p.1331-49, 1999.

HERBERT, I.V.; SMITH, T. S. Sarcocystosis. Parasitol. Today, [s. 1.], v.3, p.16-21, 1987.

HORNTON, H. Sarcosporidiosis - a Review. Trop. Anim. Health Prod., [s. 1.], v.4, p.54-7, 1972.

JEFFREY, M. et al. Immunocytochemistry of Ovine Sporozoan Encephalitis and Encephalomyelitis. J. Comp. Pathol., [s. 1.], v.98, p.21324, 1988.

LEEK, R. G.; FAYER, R.; JOHNSON, A. J. Sheep Experimentally Infected with Sarcocystis from Dogs. I. Disease in Young Lambs. J. Parasitol., [s. 1.], v.61, p.642-50, 1977.

LINDSAY, D. S; BLAGBURN, B. L.; BRAUNDM, K. G. Sarcocystis spp. and Sarcocystosis. Bam, [s. 1.], v.5, p.249-54, 1995.

MACKIE, J. T.; DUBEY, J. P. Congenital Sarcocystosis in a Saanen Goat. J. Parasitol., [s. 1.], v.82, p.350-1,1996.

MAURER, J. J. Rapid Detection and Limitations of Molecular Techniques. Annu. Rev. Food Sci. Technol., [s. 1.], v.2, p.259-79, 2011.

MORÉ, G. et al. Serologic Profiles for Sarcocystis sp. and Neospora caninum and Productive Performance in Naturally Infected Beef Calves. Parasitol. Res., [s. 1.], v.106, p.689-93, 2010.

MOTAMEDI, G. R. et al. Ultrastructural and Molecular Characterization of Sarcocystis Isolated from Camel (Camelus dromedarius) in Iran. Parasitol. Res., [s. 1.], v.108, p.949-54, 2011. 
MUGRIDGE, N. B. et al. Effects of Sequence Alignment and Structural Domains of Ribosomal DNA on Phylogeny Reconstruction for the Protozoan Family Sarcocystidae. Mol. Biol. Evol., [s. 1.], v.17, p.184253, 2000.

MÜLLER, J.; HEMPHILL, A. In vitro Culture Systems for the Study of Apicomplexan Parasites in Farm Animals. Int. J. Parasitol., [s. 1.], v.43, p.115-24, 2013.

O'DONOGHUE, P. J.; WEYRETER, H. Examinations on the Serodiagnosis of Sarcocystis Infections. II. Class-Specific Immunoglobulin Responses in Mice, Pigs, and Sheep. Zentralbl. Bakteriol. Mikrobiol Hyg. A., [s. 1.], v.257, p.168-84, 1984.

O’DONOGHUE, P. J.; WILKINSON, R. G. Antibody Development and Cellular Immune Responses in Sheep Immunized and Challenged with Sarcocystis tenella Sporocysts. Vet. Parasitol., [s. 1.], v.27, p.25165,1988.

OZKAYHAN, M. A. et al. The Prevalence of Sarcocystis Species in Sheep Slaughtered in Municipality Slaughterhouse in Kirikkale. Turkiye Parazitol. Derg., [s. 1.], v.31, p.272-6, 2007.

PACHECO, R. G.; BOTELHO, G. G.; TEIXEIRA, M. N. Coagulograma de Ovinos Experimentalmente Infectados com Sarcocystis tenella (Railliet, 1886) Moulé, 1886 (Apicomplexa: Sarcocystidae). Semina, [s. 1.], v.16, p.26-8,1995.

PESCADOR, C. A. et al. Aborto ovino associado com infecção por Sarcocystis sp. Pesq. Vet. Bras., [s. 1.], v.10, p.393-7,2006.

PRAKAS, P. et al. Sarcocystis sp. from the Herring Gull (Larus argentatus) Identity to Sarcocystis wobeseri Based on Cyst Morphology and DNA Results. Parasitol. Res., [s. 1.], v.109, p.1603-8, 2011.

PUGH, D. G. Clínica de ovinos e caprinos. São Paulo: Roca, 2004. 528p.

ROMMEL, M. Recent Advances in the Knowledge of the Biology of the Cyst-Forming Coccidia. Angew. Parasitol., [s. 1.], v.30, p.73-183, 1989. SILVA, R. C.; SU, C.; LANGONI, H. First Identification of Sarcocystis tenella (Railliet, 1886) Moulé, 1886 (Protozoa: Apicomplexa) by PCR in Naturally Infected Sheep from Brazil. Vet. Parasitol., [s. 1.], v.165, p.332-6, 2009.

SMITH, T. S.; HERBERT, I.V. Experimental Microcyst Sarcocystis Infection in Lambs: Serology and Immunohistochemistry. Vet. Rec., [s. 1.], v.119, p.547-50, 1986.

TENTER, A. M. Comparison of Dot-ELISA, ELISA and IFAT for the Detection of IgG Antibodies to Sarcocystis muris in Experimentally 
Infected and Immunized Mice. Vet. Parasitol., [s. 1.], v.29, p.89-104, 1988.

TENTER, A. M. Current Research on Sarcocystis Species of Domestic Animals. Int. J. Parasitol., [s. 1.], v.25, p.1311-30, 1995.

UGGLA, A.; HILALI, M.; LÖVGREN, K. Serological Responses in Sarcocystis cruzi Infected Calves Challenged with Toxoplasma gondii. Res. Vet. Sci., [s. 1.], v.43, p.127-9, 1987. ; BUXTON, D. Immune Responses Against Toxoplasma and Sarcocystis Infections in Ruminants: Diagnosis and Prospects for Vaccination. Rev. Sci. Tech., [s. 1.], v.9, p.441-62, 1990. 
ARTRÓPODES 


\section{9 \\ MIÍASES $^{1}$}

Entende-se por miíase "a infestação de vertebrados vivos por larvas de dípteros que, pelo menos durante certo período, se alimentam dos tecidos vivos ou mortos do hospedeiro, de suas substâncias corporais líquidas ou do alimento por ele ingerido" (Linhares, 2000). As principais espécies causadoras de miíases em ovinos criados no Brasil são Cochliomyia hominivorax (bicheira), Dermatobia hominis (berne) e Oestrus ovis (bicho da cabeça).

\section{Cochliomyia hominivorax}

\section{Introdução}

Cochliomyia hominivorax é uma espécie de mosca produtora de miíase primária, vulgarmente conhecida como bicheira. Suas lar-

1 Capítulo de autoria de Bruna Fernanda da Silva. Biológa, com mestrado (2007) e doutorado (2012) pelo curso de pós-graduação em Biologia Geral e Aplicada, área de concentração Biologia de Parasitas e Microrganismos, da Universidade Estadual Paulista "Júlio de Mesquita Filho" (Unesp), campus de Botucatu. Atualmente é docente e pesquisadora no programa de mestrado em Ambiente e Saúde da Universidade do Planalto Catarinense (Uniplac). Tem experiência na área de Parasitologia, com ênfase em parasitas de ovinos. 
vas são parasitas obrigatórios e alimentam-se dos tecidos vivos de todos os animais de sangue quente, inclusive o homem (Guimarães et al., 1983).

A mosca de C. hominivorax possui coloração azul ou azul-esverdeado, é ovípara e, após a cópula, deposita seus ovos em massas compactas, com média de duzentos a trezentos ovos (Figura 62), nas bordas de ferimentos da pele ou em mucosas. As larvas de primeiro estádio (L1) eclodem em menos de 24 horas e começam a alimentar-se dos tecidos vivos do hospedeiro parasitado, ficam agregadas e com as peças bucais voltadas para o interior da ferida, mantendo os espiráculos respiratórios voltados para o exterior. As larvas alimentam-se no hospedeiro por um período de aproximadamente sete dias, e, durante esse período, crescem e sofrem mais duas mudas, para larva de segundo e terceiro estádio (L2 e L3). A L3 madura abandona a ferida e cai no solo, onde se enterra e se transforma em pupa, e esta, após um período de pupação, que pode variar de uma semana até dois meses, dará origem à mosca, reiniciando o ciclo (ibidem). O desenvolvimento é fortemente influenciado pelas condições climáticas do ambiente, sendo mais lento sob baixas temperaturas, mas não foi registrada a ocorrência de diapausa (Hall, 1991). No geral, sob condições ótimas, o ciclo de vida pode se completar em menos de três semanas (Vargas-Terán et al., 2005).

A parte mais importante do ciclo de C. hominivorax e que requer identificação é a fase larval. Para realizar a identificação dos diferentes estádios larvais é necessário extrair as larvas da parte mais profunda da ferida infestada, evitando assim que sejam colhidas larvas de parasitas facultativos, como larvas de Cochliomyia macellaria, que são superficialmente muito similares às larvas de C. hominivorax e podem eventualmente colonizar as partes rasas da ferida.

A presença de pigmentação de cor escura nos troncos traqueais das larvas de C. hominivorax é a principal característica morfológica que a diferencia de outras espécies. Tal pigmentação é ausente nas larvas de C. macellaria, por exemplo (Guimarães et al., 1983). 
Figura 62 - Postura de ovos de Cochliomyia hominivorax junto de lesão localizada entre as unhas do casco de um ovino

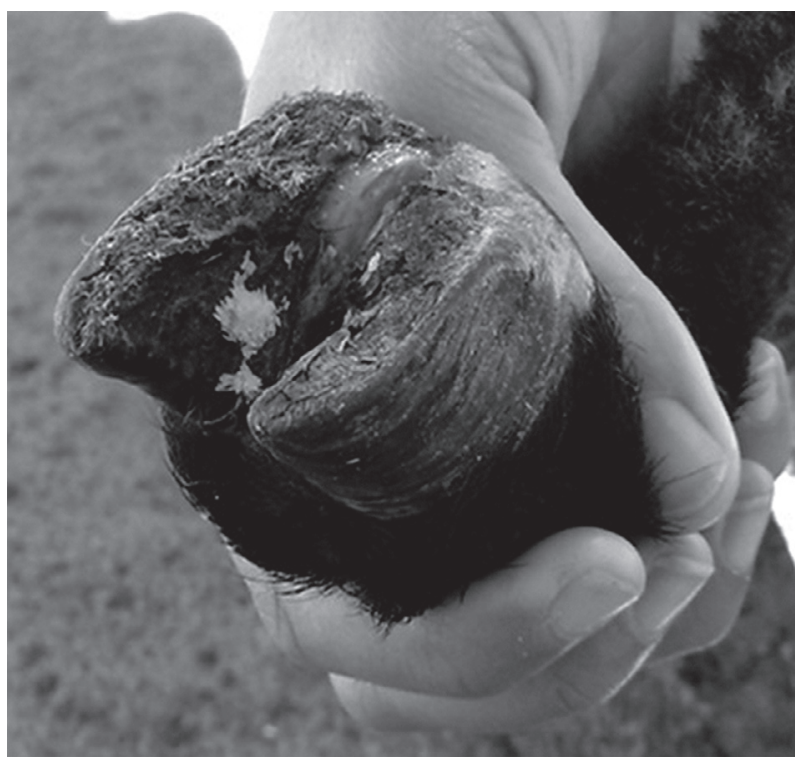

Tanto na L2 quanto na L3, a pigmentação dos troncos traqueais é visualizada em três a quatro segmentos terminais do corpo, porém, na L2 é visualmente observado até um pouco além da metade do corpo da larva (Guimarães et al., 1983; Hall, 1991). Algumas outras características são utilizadas para identificar as larvas de $C$. hominivorax e diferenciá-las das larvas de C. macellaria, tais como a margem posterior do segmento $11 \mathrm{com}$ anel completo de espinhos, espiráculos posteriores maiores, espiráculos anteriores com sete a nove dígitos e parede ventral da faringe lisa (Guimarães et al., 1983). Vale ressaltar que a identificação é mais fácil de ser realizada em espécimes vivos, pois nas larvas preservadas em álcool $70 \%$ faz-se necessário dissecá-las para remover o tecido opaco que cobre o tronco traqueal para realizar a identificação (Hall, 1991).

A L3 apresenta coloração branco/creme, possui corpo cilíndrico com $6 \mathrm{~mm}$ a $17 \mathrm{~mm}$ de comprimento por 1,6 $\mathrm{mm}$ a $3,5 \mathrm{~mm}$ de 
largura. Os espinhos que circundam o corpo da larva, com média máxima de $130 \mu \mathrm{m}$ de comprimento, são bem mais longos quando comparados aos das larvas de moscas não varejeiras, e eles ajudam a manter a larva posicionada na ferida. Quando a L3 está madura, pronta para pupar, apresenta espiráculos posteriores com pigmentação castanho-escuro ou negra e comprimento de $15 \mathrm{~mm}$ a $16 \mathrm{~mm}$ (ibidem).

A mosca adulta é encontrada com muito menos frequência do que as larvas. As espécies de Cochliomyia apresentam coloração azul-metálico ou azul-esverdeado, com três faixas pretas longitudinais no tórax (ibidem). C. hominivorax distingue-se das demais espécies do gênero pela presença de pelos pretos na extremidade inferior da parafrontália, esclerito subcostal preto, ausência de pilosidade cinza-prateada na área laterodorsal e comprimento de $8 \mathrm{~mm}$ a 10 mm (Guimarães et al., 1983).

As fêmeas que emergem do pupário copulam uma única vez durante a vida, enquanto que os machos copulam de quatro a cinco vezes (Moya-Borja, 2003). A fêmea, após emergir do pupário, passa por uma sequência de fases de maturação, as quais apresentam diferentes características comportamentais, ecológicas e fisiológicas. Durante os dois primeiros dias após a eclosão da pupa, a mosca permanece em repouso sobre árvores, alimentando-se do néctar das flores, e não está receptiva aos machos; aos três ou quatro dias de idade, a mosca torna-se sexualmente madura e procura "sítios de reprodução", locais onde há um grupo de machos, que irão copular com as fêmeas receptivas; e na última fase, as fêmeas, após a cópula, com quatro a cinco dias de idade, saem em busca de feridas em animais de sangue quente para depositar os ovos, com periodicidade de três dias, alternando entre oviposição e descanso. A fêmea é autógena, copula uma única vez e vive em média dez dias, período em que completa dois ciclos vitelogênicos, ou seja, dois ciclos de oviposição. Porém, algumas poucas fêmeas podem viver aproximadamente de três a cinco semanas na natureza, com ciclos contínuos de oviposição, o que exige uma fonte exógena de 
proteína, que a mosca adquire alimentando-se do exudato seroso das feridas onde realiza a oviposição (Thomas, 1993). A mosca adulta pode percorrer longas distâncias, em média $40 \mathrm{~km}$ a $55 \mathrm{~km}$ por semana, mas excepcionalmente pode percorrer até $290 \mathrm{~km} \mathrm{em}$ menos de duas semanas (Hall, 1991).

\section{Patogenia e sinais clínicos}

A "mosca varejeira" ou "mosca da bicheira", como a mosca $C$. hominivorax é popularmente conhecida, é considerada uma séria praga para os animais domésticos. Qualquer tipo de ferimento, desde um simples arranhão, pode ser infestado por larvas dessa espécie, dando origem à "bicheira". Durante o parasitismo, as larvas invadem partes profundas do tecido do hospedeiro, e a extensa ferida, resultado da alimentação das larvas, pode causar a morte do animal (Hall; Wall, 1995). Além disso, as feridas infestadas apresentam um odor característico que é atrativo para outras fêmeas grávidas realizarem a oviposição, resultando em até três mil larvas em uma única ferida, o que também aumenta a susceptibilidade a infecções secundárias (Hall, 1991; Vargas-Terán et al., 2005).

Estudos demonstram que alguns fatores podem aumentar a predisposição ao ataque de bicheiras nos ovinos, tais como a amputação da cauda dos cordeiros, a ocorrência da enfermidade pododermatite contagiosa (footrot) (Figura 63) e lesões decorrentes da tosquia (Amarante et al., 1992; Madeira et al., 1998). A vulva das ovelhas também é outro local comumente atacado pelas larvas, e foi observada prevalência elevada principalmente durante os períodos quentes do ano, coincidindo com o cio das ovelhas (Amarante et al., 1992). O tamanho do rebanho foi outro fator correlacionado com o parasitismo pelas larvas de C. hominivorax nos ovinos: quanto maior o rebanho (> quinhentos animais), maiores as chances de infestação, fato atribuído à dificuldade em realizar inspeção individual minuciosa para identificar e tratar os animais com ferimentos (Madeira et al., 1998). 
Figura 63 - Larvas de Dermatobia hominis entre as unhas do casco de um ovino

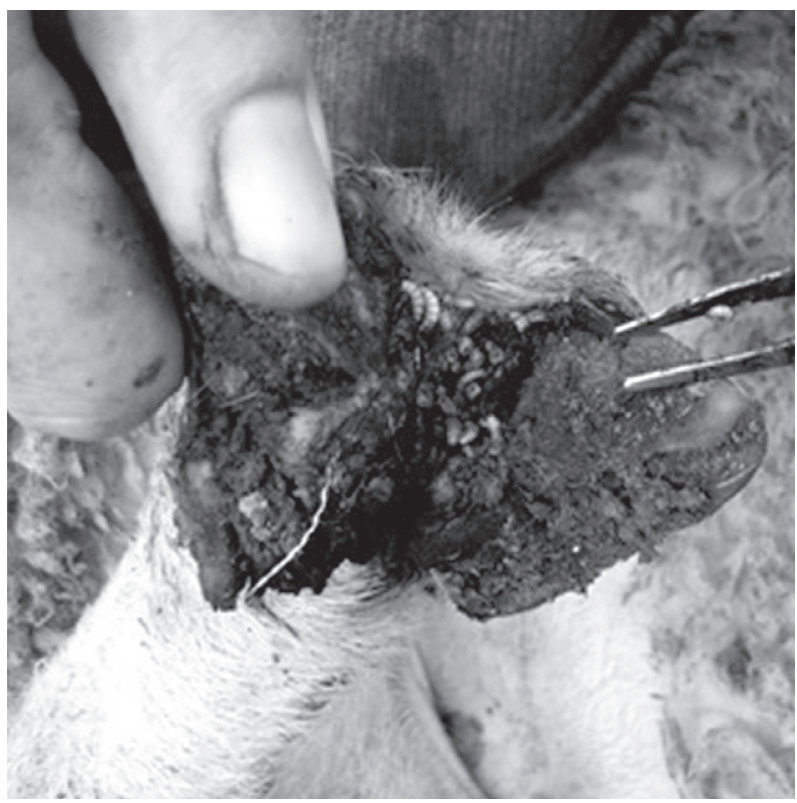

Foto gentilmente cedida pela Equipe CordeiroBiz.

Do mesmo modo, em bovinos, intervenções relacionadas ao manejo, tais como castração, descorna, marcação e até mesmo um simples arranhão ou feridas decorrentes do parasitismo por berne (larvas de Dermatobia hominis) e carrapatos predispõem o gado ao ataque de bicheiras (Lello et al., 1982; Grisi et al., 2002). A miíase umbilical em bezerros também é muito frequente (Guimarães et al., 1983; Hall, 1991; Grisi et al., 2002), assim como na vulva das parturientes, especialmente quando há retenção de anexos fetais após o trabalho de parto (Hall, 1991; Grisi et al., 2002).

A miíase em humanos se dá principalmente na população que vive em condições precárias de higiene, como indivíduos alcoolizados, sujos, que dormem ao ar livre ou que possuem feridas ou ulcerações na pele (Guimarães et al., 1983). A infestação pode se tornar rapidamente debilitante quando ocorre nas cavidades nasal, ocular, bucal e/ou auricular (Robinson et al., 2009). 
Em animais infestados pelas larvas de C. hominivorax, são observadas lesões profundas de aspecto crateriforme e com liberação de fluídos sanguinolentos de odor pútrido, tornando-se mais evidente a partir do terceiro dia de infestação. A partir do sexto dia, quando as L3 começam a abandonar o hospedeiro, as lesões apresentam-se necróticas e com produção de secreção purulenta. Além disso, os animais apresentam inquietação, inapetência e febre durante o período de infestação (Morais et al., 2003). Se não tratado com urgência, o parasitismo por larvas de C. hominivorax pode levar o animal à morte.

C. hominivorax é responsável por significativas perdas econômicas não só devido à redução de produtividade, mutilação e mortalidade de animais, mas também aos gastos com mão de obra e antiparasitários, portanto, é considerada uma séria praga, especialmente em criações de bovinos, ovinos, caprinos e suínos, ocasionando sérios prejuízos econômicos (Guimarães et al., 1983; Madeira et al., 1998; Vargas-Terán et al., 2005). Só no Brasil, os prejuízos associados às bicheiras foram estimados em US\$ $150 \mathrm{mi}$ lhões anuais (Grisi et al., 2002), e infelizmente não há dados sobre os prejuízos causados por essa mosca nos outros países da América do Sul (Moya-Borja, 2003).

\section{Epidemiologia}

A mosca C. hominivorax é nativa das Américas (Lello et al., 1982; Moya-Borja, 2003) e é endêmica na maioria das regiões do Brasil (Madeira et al., 1998). Embora seja encontrada em regiões com clima tropical e subtropical, a mosca também desenvolve-se em regiões de clima temperado, quando as condições climáticas são favoráveis (Stuart et al., 1995).

Historicamente, sua distribuição estendia-se desde a região central e sul dos Estados Unidos da América até o México, América Central, Caribe e América do Sul (Hall, 1991). Como resultado de 45 anos de estudos sobre a biologia da C. hominivorax e participação ativa dos pecuaristas, a supressão e erradicação foram alcançadas nos Estados Unidos da América, no México, em Belize, na Gua- 
temala, em Honduras, em El Salvador, na Nicarágua, na Costa Rica, no norte do Canal do Panamá, em algumas ilhas do Caribe e também da Líbia e no norte da África, utilizando insetos estéreis, por meio da técnica de esterilização dos machos com radiação gama (Sterile Insect Technique - SIT)2 (Vargas-Terán et al., 2005). Porém, continua sendo causadora de sérios prejuízos no Brasil e em outros países da América do Sul (Grisi et al., 2002).

Condições locais, como a distribuição e densidade dos animais de produção e das populações de animais silvestres, as práticas de manejo, o movimento comercial de animais, a densidade de população humana, as condições socioeconômicas, os serviços públicos de saúde, a geografia e fatores climáticos ditam a gravidade das infestações e a magnitude do problema econômico (Vargas-Terán et al., 2005; Robinson et al., 2009). Porém, entre essas variáveis, as condições climáticas do ambiente constituem o principal fator com influência na epidemiologia de C. hominivorax (Rahn; Barger, 1973; Vargas-Terán et al., 2005).

A temperatura, por exemplo, tem grande influência, especialmente na fase de pupa. Quando a temperatura na superfície do solo atinge $40{ }^{\circ} \mathrm{C}$ ou mais, a sobrevivência da pupa é severamente reduzida (Rahn; Barger, 1973). A duração do período de pupação que ocorre no solo também é influenciada pela temperatura: dependendo da estação do ano, pode variar de uma semana até dois meses. No Rio Grande do Sul, por exemplo, em condições naturais de campo, durante o verão, quando a temperatura média foi de $24^{\circ} \mathrm{C}$, os adultos emergiram cerca de dez dias após a pupação, enquanto que durante os meses mais frios o período de pupação atingiu 43 dias, período em que a temperatura média foi de $13^{\circ} \mathrm{C}$ (Oliveira, 1986a). Outro fator importante que tem influência na emergên-

2 A Técnica do Inseto Estéril, ou "Sterile Insect Technique - SIT", consiste em produzir machos estéreis no laboratório e soltá-los na natureza. Esses machos devem se manter aptos a copular com as fêmeas férteis, que por consequência produzirão ovos inférteis. O sucesso dessa técnica se dá com a liberação contínua desses machos estéreis na natureza, bem como com a capacidade de estes acasalarem com a maior proporção possível de fêmeas férteis, levando a população de moscas à extinção. 
cia das moscas da bicheira é a umidade do solo. Tanto a seca prolongada como a saturação de umidade do solo causam redução na emergência das moscas, enquanto que a umidade intermediária (67\%) foi considerada adequada para o desenvolvimento da pupa e a emergência dos adultos (Stuart et al., 1995).

A população de mosca adulta também é variável durante o ano em função das condições climáticas, sendo observada maior abundância durante os meses quentes e úmidos do ano (Rahn; Barger, 1973; Hall, 1991; Vargas-Terán et al., 2005). Em Porto Alegre (RS), o ápice de recuperação da mosca ocorreu durante o final do verão até o outono, e a menor, durante os meses de inverno e o início da primavera (Oliveira, 1986b). Da mesma, forma em Botucatu (SP), em estudo realizado com ovinos, miíases devido ao parasitismo por larvas de C. hominivorax foram observadas durante todo o ano (Figura 64), porém com alta incidência durante os meses de verão e início do outono (janeiro-abril), coincidindo com o período de elevadas temperaturas e alta incidência de chuvas (Amarante et al., 1992; Madeira et al., 1998), resultado semelhante ao observado em bovinos na mesma região (Lello et al., 1982).

Figura 64 - Variação sazonal no número de casos de miíases por Cochliomyia hominivorax em um rebanho de ovinos ao longo de doze meses em Botucatu (SP) (Amarante et al., 1992)

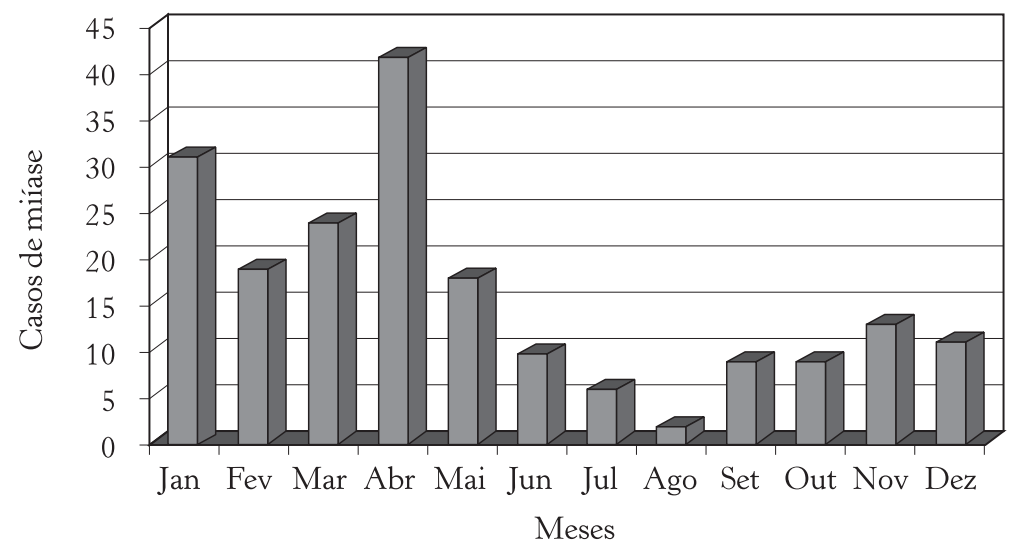




\section{Profilaxia}

É possível prevenir a instalação de bicheiras por meio de práticas adequadas de manejo, bem como com a utilização de antiparasitários, produtos repelentes e cicatrizantes. Recomenda-se programar intervenções relacionadas ao manejo de ovinos e bovinos, tais como castração, marcação, descorna, corte de cauda, tosquia, entre outras, para a época de baixo parasitismo (Madeira et al., 1998). Além disso, os animais devem ser examinados com frequência.

Em animais parasitados, as larvas devem ser removidas, e suas feridas devem ser tratadas com urgência. Neste caso, o uso de inseticidas é indispensável. Entre os antiparasitários utilizados para a prevenção/controle da bicheira está a doramectina (Moya-Borja et al., 1993; 1997; Muniz et al., 1995a; Muniz et al., 1995b; Sanavria et al., 1996; Caproni Jr et al., 1998; Anziani et al., 2000), ivermectina (Benitez et al., 1997), fipronil (Lima et al., 2004), dicyclanil (Anziani et al., 1998), nitenpyram (Correia et al., 2010) e também os organofosforados coumaphos, ronnel, chlorpyrifos, chlorfenvinfos e trichlorfon (Moya-Borja, 2003). Muitas vezes, faz-se necessária a aplicação de antibióticos sistêmicos para evitar a ocorrência de infecções bacterianas secundárias, o que também facilita a cicatrização.

\section{Considerações finais}

Cochliomyia hominivorax é um parasita que acomete todos os animais de sangue quente e é considerado uma séria praga para os animais de produção, sendo responsável por significativas perdas na pecuária brasileira.

Qualquer ferida, por menor que seja, é atrativo para a mosca depositar os ovos. Os animais podem ser acometidos pela bicheira durante qualquer época do ano, mas a prevalência é mais elevada durante os meses quentes e chuvosos.

Embora a prevalência dessa parasitose no Brasil seja elevada, os estudos sobre a biologia e epidemiologia desse parasita no país 
são ainda insuficientes, e apenas com tal conhecimento é possível realizar trabalhos preventivos mais eficazes e até mesmo considerar a possibilidade de erradicação, assim como foi realizado nos países da América do Norte e da América Central.

\section{Dermatobia hominis}

\section{Introdução}

Dermatobia hominis (Díptera: Cuterebridae) é mais uma espécie de mosca produtora de miíase primária. Suas larvas, parasitas obrigatórios, produzem miíase furuncular, vulgarmente denominada berne, em uma ampla variedade de hospedeiros vertebrados, inclusive no homem (Cogley; Cogley, 1989).

A mosca D. hominis possui coloração azul-metálico, é ovípara e, após a cópula, deposita seus ovos no corpo de outros dípteros (foréticos), especialmente moscas ou mosquitos zoófilos que geralmente são encontrados frequentando bovinos e equinos. Durante o voo, a Dermatobia captura e imobiliza, com o auxílio das pernas, o inseto forético e então deposita seus ovos, em número variável, na extremidade lateroventral do abdome. Estes permanecem fortemente aderidos por uma substância cimentante que impede que os ovos sejam removidos do abdome dos insetos foréticos (Figura 65). Os ovos são ligados aos vetores pela extremidade caudal e em posição inclinada, de forma que a extremidade cefálica fique em contato com a pele do hospedeiro quando o vetor pousar sobre este. Os ovos permanecem incubados no abdome do inseto forético e, após aproximadamente sete dias, darão origem a uma larva de primeiro estádio (L1). Quando o inseto forético pousa sobre um hospedeiro, a L1, estimulada pelo calor natural emanado pelo corpo do hospedeiro, abandona o ovo através de uma abertura opercular localizada na região anterior do ovo. A larva penetra ativamente pela pele do hospedeiro e invade o tecido subcutâneo, onde permanecerá de 35 a 42 dias, em média, período em que cresce, desenvolve e sofre 
duas mudas para larva de segundo e terceiro estádio (L2 e L3). No mesmo local de penetração da larva, é mantido um pequeno orifício, local por onde esta respira durante o desenvolvimento mantendo os espiráculos respiratórios posteriores voltados para o exterior. Ao atingir a maturidade, a L3 abandona o hospedeiro, saindo pelo mesmo orifício por onde penetrou, cai no solo, enterra-se e transforma-se em pupa, e esta, após um período de pupação que varia de 34 a 78 dias, dependendo das condições climáticas do ambiente, dará origem à mosca, reiniciando o ciclo (Banegas et al., 1967; Guimarães et al., 1983; Hall; Wall, 1995). No geral, em condições ótimas de temperatura e umidade, o ciclo pode se completar em oitenta dias (Banegas et al., 1967).

Figura 65 - Ovos de D. hominis aderidos ao abdome de Musca domestica

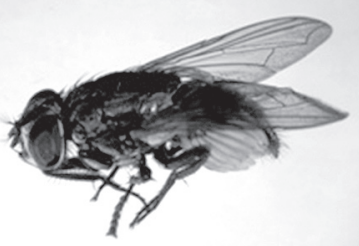

$\cdots$
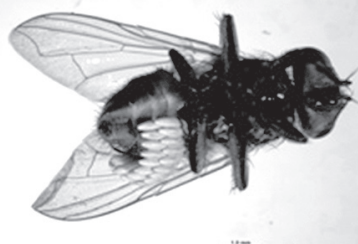

Fotos gentilmente cedidas por José Henrique das Neves.

O formato piriforme da larva de D. hominis é uma das características que a diferenciam dos demais cuterebrídeos (Catts, 1982), assim como a presença e a disposição dos espinhos ao longo dos segmentos corporais (Figura 66), sendo que dos doze segmentos que compõem o corpo da larva, apenas os quatro últimos não apresentam espinhos (Koone; Banegas, 1959).

$\mathrm{O}$ aparelho bucal, equipado com um par de ganchos orais (Figura 67), localiza-se no primeiro segmento do corpo da larva (ibidem). A L1 apresenta cutícula esbranquiçada e mede de $1 \mathrm{~mm}$ a 1,6 $\mathrm{mm}$ de comprimento por $0,3 \mathrm{~mm}$ a $0,6 \mathrm{~mm}$ de largura, possui apenas 
uma abertura respiratória em cada espiráculo posterior, e a região cefálica é levemente mais larga. Já a L2 apresenta crescimento larval evidenciado pelo intumescimento do segundo e terceiro segmentos torácicos e dos quatro primeiros abdominais, enquanto que os posteriores continuam alongados. A L3 madura apresenta cutícula amarelada, corpo ovoide e tamanho por volta de $2 \mathrm{~cm}$ de comprimento por $1 \mathrm{~cm}$ de largura (Lello et al., 1984), e nessa fase os espiráculos respiratórios posteriores, localizados no último segmento do corpo da larva, são projetados para fora e tornam-se bastante proeminentes (Koone; Banegas, 1959).

Figura 66 - Larvas de Dermatobia hominis
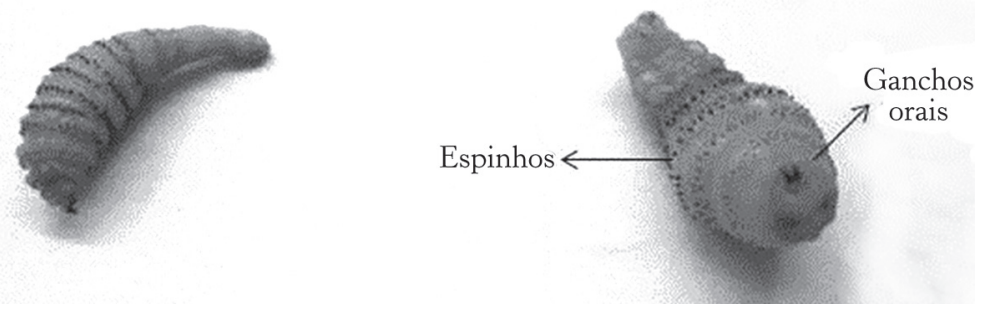

Não existem características morfológicas externas que diferenciem a larva que dará origem a macho ou fêmea, mas é possível realizar a distinção anatômica entre testículo e ovário em L3 com peso a partir de $400 \mathrm{mg}$ (Lello et al., 1984). O tempo de parasitismo e o peso das larvas de $D$. hominis determinam o sexo da mosca adulta, sendo que as larvas que originam machos têm média de peso e tempo de parasitismo inferior à daquelas que originam fêmeas. Neste estudo, as larvas que originaram machos permaneceram no hospedeiro em média 37 dias e pesaram entre 400 mg e 650 mg, enquanto que as larvas que deram origem a fêmeas pesaram entre 550 mg a 810 mg e apresentaram duração média da fase parasitária de 42 dias (Ribeiro; Oliveira, 1983). Em bovinos, foi observado que a fase parasitária varia entre quarenta e sessenta dias, dependendo da época do ano, sendo que durante a estação seca o desenvolvimento 
das larvas pode levar até 120 dias (Guimarães et al., 1983). Em suínos infestados artificialmente, a duração média da fase parasitária foi de 44 dias, e nenhuma larva se desenvolveu nas infestações artificiais realizadas em equinos (Brito et al., 2001).

A L3 madura geralmente abandona o hospedeiro durante a noite ou nas primeiras horas da madrugada, dessa forma evita a ação abrasiva dos raios solares ou a ação de predadores diurnos (Catts, 1982; Ribeiro; Oliveira, 1983; Moya-Borja, 2003). Logo após cair no solo, a larva procura enterrar-se para dar início à fase de pupa. Se o solo estiver úmido e solto, a L3 penetra em aproximadamente dez minutos a quinze minutos, enquanto levará duas horas ou mais, caso o solo esteja compactado. Se a larva não conseguir penetrar no solo, pupará sobre ele, mas dessas pupas não emergirão adultos (Guimarães et al., 1983).

A pupa tem o formato semelhante ao da L3 madura, porém a última cutícula da larva endurece e escurece com o tempo, tornando-se quase preta no momento em que os adultos estão prontos para emergir (Koone; Banegas, 1959). Nos últimos dias de desenvolvimento das pupas, os testículos do macho já possuem espermatozoides maduros, e no momento da eclosão, os ovos estão totalmente desenvolvidos no ovário das fêmeas (Banegas; Mourier, 1967). A maioria dos adultos emerge no período da manhã, e entre uma hora e meia e quatro horas após a emergência já estão sexualmente maduros, aptos ao acasalamento (ibidem).

A mosca adulta (Figura 67) raramente é vista na natureza e tem por habitat locais úmidos, onde os arbustos e árvores apresentam crescimento denso, portanto, geralmente são encontradas em abundância nas margens de matas, florestas-galeria e plantações de Eucalyptus (Koone; Banegas, 1959; Guimarães et al., 1983). A mosca adulta $D$. hominis tem tamanho médio, com cerca de $12 \mathrm{~mm}$ de comprimento, tórax azul-metálico revestido de pelos escuros e cabeça com coloração amarela, escurecida na parte superior (Guimarães et al., 1983). A fecundidade da fêmea varia entre oitocentos e mil ovos, e a partir do segundo dia de vida adulta esta já realiza a postura de ovos viáveis (Catts, 1982). 
Figura 67 - Exemplar adulto de Dermatobia hominis

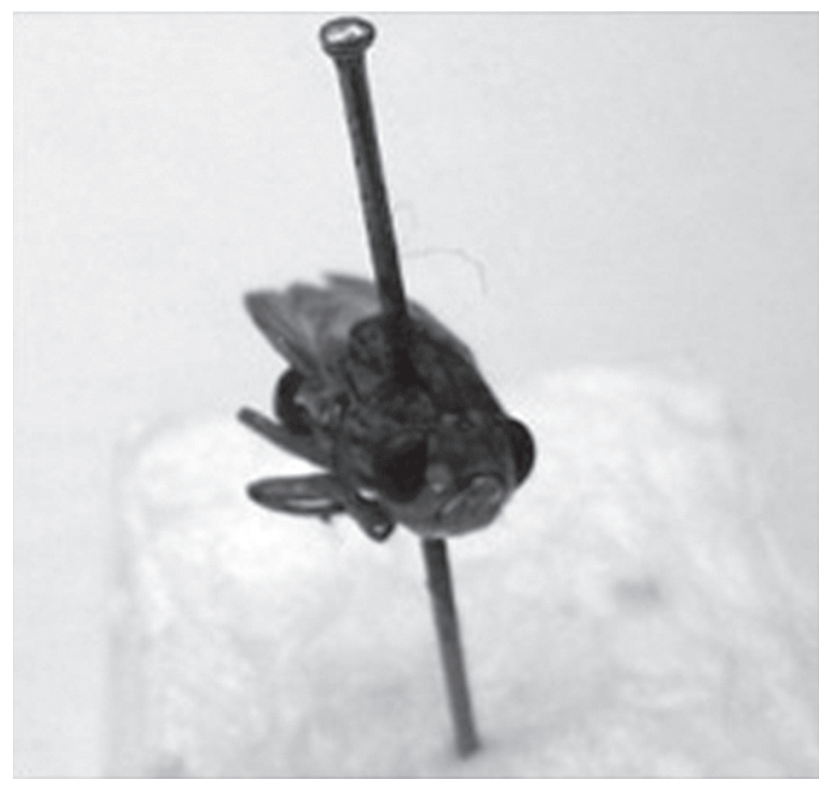

Em condições naturais de campo, a mosca $D$. hominis é totalmente dependente de outros insetos, que funcionam como foréticos ou carreadores de ovos. O número de ovos nos foréticos varia de acordo com a espécie e as característica dos insetos, que no geral apresentam hábitos zoófilos, tamanho moderado e atividade diurna (Bates, 1943). Mais de cinquenta espécies de dípteros pertencentes a diversas famílias, tais como Muscidae, Calliphoridae, Sarcophagidae, Fanniidae, Culicidae, Tabanidae, entre outras, foram listados como foréticos (Bates, 1943; Guimarães et al., 1983; Ribeiro et al., 1985; Gomes et al., 1998). D. hominis pode realizar várias posturas (Guimarães et al., 1983), e, no geral, são encontrados de dez a oitenta ovos nos insetos foréticos (Banegas et al., 1967).

Os adultos possuem o aparelho bucal atrofiado, portanto, não se alimentam na natureza e sobrevivem das reservas acumuladas durante a fase larval (Sancho, 1988), consequentemente, o período de vida da mosca é curto, varia entre um e dezenove dias (Ribeiro; 
Oliveira, 1987; Oliveira, 1991). Além disso, a sobrevivência da mosca também é influenciada pela temperatura, sendo significativamente reduzida em temperaturas abaixo de $18{ }^{\circ} \mathrm{C}$ ou acima de $30{ }^{\circ} \mathrm{C}$ (Sancho, 1988).

\section{Patogenia e sinais clínicos}

A mosca D. hominis ou "mosca do berne" é considerada um dos ectoparasitas mais importantes da América Latina. Embora os prejuízos mais sérios sejam observados na bovinocultura, o berne também infesta ovinos, cães, suínos, animais silvestres e outros mamíferos, inclusive o homem (Roncalli, 1984; Hall; Wall, 1995). No homem, as larvas causam miíases dérmicas, palpebrais, oftalmomiíases, entre outras (Guimarães et al., 1983).

Ao penetrar no tecido subcutâneo do hospedeiro, o "berne", como a larva é popularmente conhecida, permanece enquistado no ponto de entrada, mantendo um pequeno orifício pelo qual realiza a respiração, local onde também é observada reação inflamatória com produção de pus e outros exudatos (Banegas et al., 1967; Roncalli, 1984). Cerca de sete dias após a penetração da larva no tecido subcutâneo, o furúnculo já é notável, apresenta cerca de $1 \mathrm{~cm}$ de diâmetro e continua crescendo até o fim do desenvolvimento, medindo de $2 \mathrm{~cm}$ a $3 \mathrm{~cm}$ de diâmetro quando a L3 completa seu desenvolvimento (Barbosa et al., 2002).

Porém, tal reação inflamatória no local de penetração da larva aparentemente não inibe o desenvolvimento larval e também não resulta em aquisição de imunidade pelo hospedeiro em reinfestações subsequentes (Sancho, 1988). Durante a infestação pelo berne, é observada presença de grande quantidade de eosinófilos, basófilos e mastócitos degranulados, assim como a presença de imunoglobulinas (Oliveira-Sequeira et al., 1996; Lello et al., 1999; Lello; De Rosis, 2003). Porém, embora a resposta inflamatória seja intensa, não foi observada a morte das larvas (Lello et al., 1999), pois estas apresentam mecanismos de escape que as protegem da resposta imune do hospedeiro (Oliveira-Sequeira et al., 1996). 
Na realidade, as secreções purussanguinolentas excretadas através das aberturas dos furúnculos atraem um maior número de insetos que podem estar carreando ovos de D. hominis, e, portanto, aumenta a possibilidade de reinfestação pelas larvas do berne (Moya-Borja, 2003). Além disso, o orifício deixado pelo berne é atrativo para a "mosca da bicheira" (Cochliomyia hominivorax) realizar a oviposição, sendo que a associação entre as infestações por tais parasitas é muito comum nos rebanhos bovinos e ovinos (Lello et al., 1982; Amarante et al., 1992; Madeira et al., 1998; 2000; Grisi et al., 2002).

Embora os animais parasitados apresentem inquietação constante, não foram observadas alterações significativas nos valores de hemograma, na temperatura corporal e nas frequências cardíaca e respiratória em bovinos jovens infestados com cerca de sessenta larvas de D. hominis (Barbosa et al., 2002; 2003). No geral, a evolução do parasitismo é benigna, mas a dermatobiose seguida de infecção secundária (bacteriana e/ou por outras miíases) pode resultar em morte do hospedeiro, especialmente em animais jovens (Koone; Banegas, 1959).

No geral, a região anterior do corpo dos animais (paleta, costelas e flanco) é a área mais parasitada (Lello et al., 1982; Pinto et al., 2002; Mozzaquatro; Sanavria, 2003; Fernandes et al., 2008), pois esse é o local onde o díptero forético pode pousar tranquilamente sem ser prontamente espantado pelos movimentos da cauda ou da cabeça do animal (Lello et al., 1982; Fernandes et al., 2008). Além disso, animais de pelagem escura são mais atacados que os de pelagem clara (Sancho, 1988; Sanavria et al., 2002). Provavelmente por apresentar maior absorção de calor, os animais de pelagem escura passam mais tempo sob a sombra de árvores, local onde geralmente há um grande número de moscas e mosquitos, alguns dos quais podem estar portando ovos de D. hominis, favorecendo o parasitismo (Marsden et al., 1979).

A dermatobiose é responsável por significativas perdas econômicas, principalmente na criação de bovinos. Na maioria dos países latinos, as perdas econômicas causadas pelo berne são desconhe- 
cidas (Moya-Borja, 2003), mas só no Brasil, os prejuízos devido à redução na produção de carne e leite, à desvalorização do couro e também aos gastos com mão de obra e produtos bernicidas podem alcançar US\$ 250 milhões por ano (Grisi et al., 2002).

\section{Epidemiologia}

A mosca $D$. hominis é uma espécie endêmica na região Neotropical. É encontrada desde o sul do México $\left(24^{\circ} \mathrm{N}-26^{\circ} \mathrm{N}\right)$ até o norte da Argentina $\left(30^{\circ} \mathrm{S}-32^{\circ} \mathrm{S}\right)$, exceto Chile (Hall; Wall, 1995). A presença do berne está associada com regiões que têm temperaturas moderadamente altas durante o dia e relativamente frias durante a noite, precipitação de mediana a abundante, vegetação densa e um número razoável de animais (Moya-Borja, 2003). Portanto, as condições climáticas do ambiente têm grande influência na epidemiologia da D. hominis. O comportamento sexual das moscas, por exemplo, é reduzido em temperaturas abaixo de $23^{\circ} \mathrm{C}$ e praticamente não ocorre em temperaturas abaixo de $17^{\circ} \mathrm{C}$. Temperaturas entre $27^{\circ} \mathrm{C}$ e $30^{\circ} \mathrm{C}$, assim como a presença de luz forte, foram consideradas ótimas para o acasalamento, pois nessas condições foi observada grande proporção de fêmeas inseminadas (Banegas; Mourier, 1967; Banegas et al., 1967).

Assim como a temperatura influencia a atividade sexual dos adultos, a temperatura e a umidade têm influência especialmente no desenvolvimento das pupas. Durante os meses de primavera e verão, período que coincide com a época mais quente e úmida do ano, o desenvolvimento da pupa é mais rápido (média de 35 dias) (Oliveira, 1991), período que também coincide com elevada incidência de diversas outras espécies de dípteros, potenciais vetores de ovos de D. hominis (Gomes et al., 1998), colaborando com o aumento do parasitismo nos animais nessas épocas do ano, conforme observado em várias regiões do Brasil, como São Paulo (Lello et al., 1982), Santa Catarina (Bellato et al., 1986), Rio de Janeiro (Brito; Moya-Borja, 2000), Paraná (Pinto et al., 2002), Rio Grande do Sul (Mozzaquatro; Sanavria, 2003) e Mato Grosso do Sul (Fer- 
nandes et al., 2008). Nos meses frios, o desenvolvimento das pupas é lento (média de 65 dias), por consequência, o parasitismo é mais baixo. No geral, as pupas que se enterraram no solo no final do outono atravessam o inverno em desenvolvimento, eclodindo no final dessa estação ou no início da primavera (Oliveira, 1991).

Embora o parasitismo seja muito mais abundante em bovinos, no estado de São Paulo D. hominis foi considerado o segundo ectoparasita mais frequente nos rebanhos ovinos, perdendo apenas para o parasitismo por larvas de C. hominivorax, sendo que a associação entre as infestações por tais parasitas é muito comum nos rebanhos ovinos, uma vez que o orifício deixado pela larva de $D$. hominis é atrativo para as moscas C. hominivorax realizarem a oviposição (Amarante et al., 1992; Madeira et al., 1998, 2000).

\section{Profilaxia}

O controle de $D$. hominis é feito pela aplicação de inseticidas, a fim de matar a larva no furúnculo e prevenir a reinfestação. Entre os antiparasitários mais utilizados e que apresentam alta eficácia para o controle/prevenção da dermatobiose está a ivermectina + abamectina (Borges et al., 2008), ivermectina (Roncalli; Usher, 1988; Leite et al., 1999; Borges et al., 2008) e a doramectina (Moya-Borja et al., 1993; Muniz et al., 1995; Leite et al., 1996; 1999; Borges et al., 2008). Os organofosforados, como o trichlorfon, também apresentam eficácia para o controle do parasitismo pelas larvas de $D$. hominis, mas infelizmente apresentam um período residual curto, o que obriga o tratamento dos animais com mais frequência (Moya-Borja, 2003).

\section{Considerações finais}

Dermatobia hominis é considerado um dos ectoparasitas mais importantes da América Latina e é responsável por significativas perdas econômicas, principalmente na criação de bovinos, devido à desvalorização do couro e redução na produtividade. 
O parasitismo pelo berne é observado durante o ano todo, mas a prevalência é mais elevada durante os meses de primavera e verão, período em que são observados temperaturas e índices pluviométricos elevados.

O único método eficaz de controle do parasitismo disponível até o momento é a utilização de inseticidas. Porém, são necessários mais estudos sobre a biologia e epidemiologia desse parasita no Brasil a fim de investigar métodos menos dependentes de produtos químicos para o controle da dermatobiose.

\section{Oestrus ovis}

\section{Introdução}

Oestrus ovis L. (Diptera: Oestridae) é um parasita cosmopolita causador de míase cavitária, e suas larvas são parasitas obrigatórios da cavidade nasal e seios paranasais de ovinos e caprinos (Zumpt, 1965). Devido à localização das larvas, recebe o nome vulgar de bicho da cabeça.

A mosca de O. ovis é vivípara e deposita larvas de primeiro estádio (L1) diretamente nas fossas nasais dos ovinos e caprinos. Estas colonizam as cavidades nasais, o septo, as turbinas e o etmoide, e, em seguida, mudam para larva de segundo estádio (L2) e migram para os seios frontais, onde irão completar seu desenvolvimento em larva de terceiro estádio (L3). As L3 maduras serão expelidas para o ambiente para o período de pupação, que acontece no solo. A pupa dará origem à mosca, e, após o acasalamento, as fêmeas grávidas procuram os ovinos para depositar as larvas, reiniciando o ciclo (ibidem).

O desenvolvimento das larvas na cavidade nasal do hospedeiro, bem como a atividade da mosca no ambiente, é muito influenciado pelas condições climáticas (Cobbett; Mitchell, 1941). O desenvolvimento larval pode variar entre 25 dias e 35 dias, podendo estender-se até nove meses, dependendo da estação do ano e das condições climáticas da região (Hall; Wall, 1995). O comprimento 
da larva e a coloração/tamanho dos espiráculos, por onde as larvas respiram, são um dos parâmetros utilizados para classificar as fases de desenvolvimento em L1, L2 ou L3 (Figura 68) (Cepeda-Palacios et al., 1999).

Figura 68 - Larvas de Oestrus ovis em diferentes fases de desenvolvimento (vista dorsal)

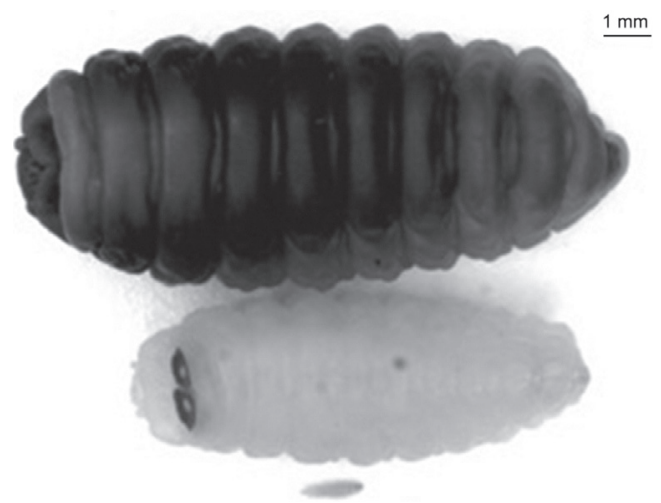

As larvas de O. ovis não são hematófagas, elas alimentam-se de fluídos extracorporais, como o muco produzido devido ao processo inflamatório que o parasitismo causa (Frugère et al., 2000; Tabouret et al., 2003a). Embora seus ganchos e espinhos danifiquem as membranas nasais, a nutrição larval não é apenas mecânica, mas está relacionada principalmente a um processo bioquímico e grande liberação de óxido de nitrogênio. Proteases estão presentes nos produtos de excreção/secreção das larvas de O. ovis e participam da pré-digestão extracorporal de proteínas, as quais são utilizadas na alimentação das larvas (Angulo-Valadez et al., 2010).

A L1, ainda com cerca de $1 \mathrm{~mm}$ de comprimento, é depositada na cavidade nasal dos ovinos, e possui ganchos orais relativamente pequenos e espiráculos posteriores não pigmentados (Figura 69). A muda de L1 para L2 ocorre quando o parasita atinge cerca de 4 mm de comprimento. Nessa fase, os espiráculos começam a ficar visíveis na cutícula da L1. 
Figura 69 - Vista ventral da larva de primeiro estádio (L1) de Oestrus ovis $0,3 \mathrm{~mm}$

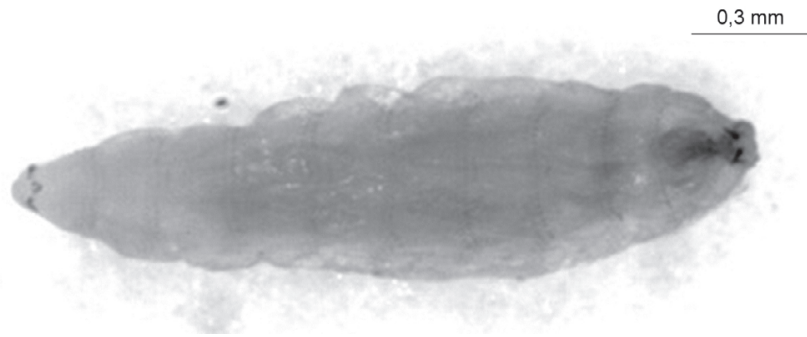

O comprimento da L2 varia entre $4 \mathrm{~mm}$ e $10 \mathrm{~mm}$, e nessa fase os espiráculos posteriores são visíveis, inicialmente com coloração variando entre o amarelo-alaranjado até o marrom-escuro (Figura $70)$.

Figura 70 - Detalhe da região posterior da larva de segundo estádio (L2) de Oestrus ovis, onde estão localizados os espiráculos respiratórios

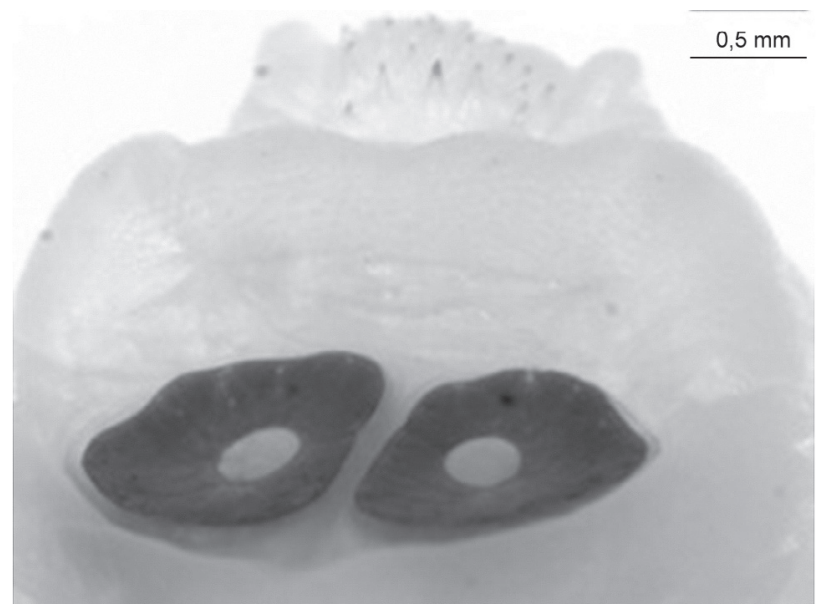

A L3 possui comprimento entre $10 \mathrm{~mm}$ e $22 \mathrm{~mm}$, e os espiráculos apresentam coloração marrom-escuro. Conforme a maturação, a L3 começa a apresentar listas dorsais pretas e muda de cor, do branco para a cor creme e depois marrom-claro, até ficar com o 
corpo totalmente escuro, e então estará pronta para ser expelida pelo hospedeiro e pupar no solo (Figura 71).

Figura 71 - Larva de terceiro estádio (L3) de Oestrus ovis em diferentes fases de desenvolvimento ( $\mathrm{A}, \mathrm{B}$ e $\mathrm{C}$ ); espiráculos respiratórios localizados na região posterior do corpo da larva (D)

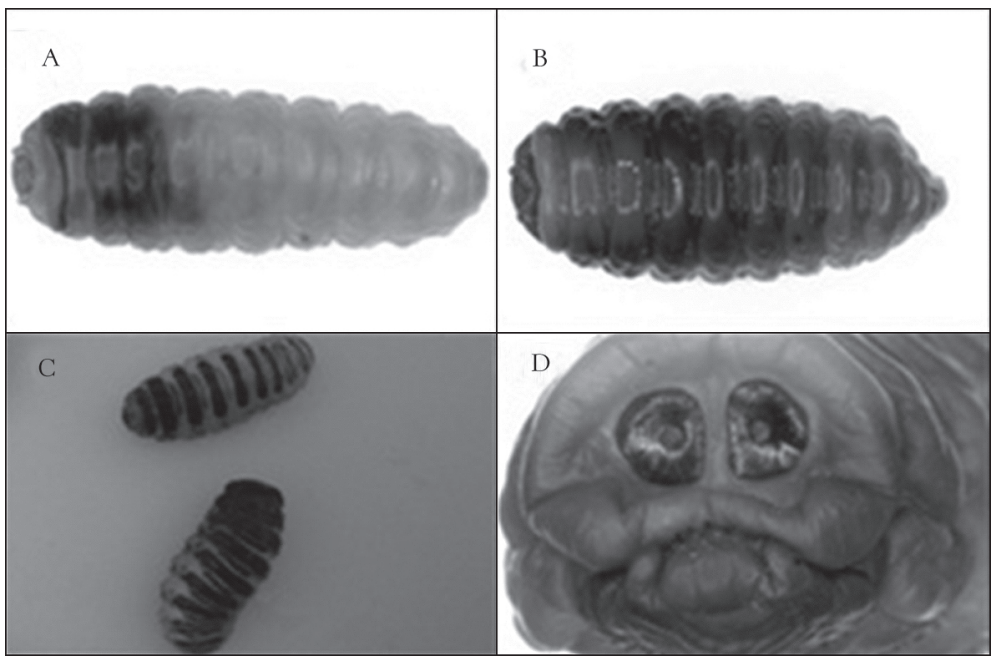

A mosca adulta tem coloração acinzentada e possui cerdas e manchas escuras pelo corpo, o que facilita a camuflagem (Figura 72). Além disso, voa rápido e possui olhos grandes, o que facilita a localização de seus hospedeiros, bem como de um parceiro para a reprodução. A vida dos adultos é curta, pois não possuem peças bucais funcionais, e, portanto, não se alimentam no ambiente e dispõem apenas das reservas energéticas acumuladas durante a fase larval, que acontece no aparelho nasal do hospedeiro (Angulo-Valadez et al., 2010). As fêmeas albergam cerca de quinhentas larvas e são capazes de infestar vários ovinos/caprinos durante seu curto período de vida (Cobbett; Mitchell, 1941). Além disso, machos e fêmeas emergem do pupário já sexualmente maduros, prontos para o acasalamento (Angulo-Valadez et al., 2010), adaptação que favorece na economia de energia. 
Figura 72 - Vista dorsal da mosca adulta de Oestrus ovis

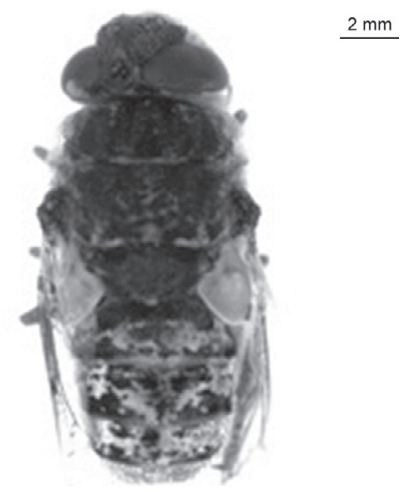

\section{Patogenia e sinais clínicos}

A oestrose ou "bicho da cabeça", como a enfermidade é comumente conhecida, afeta o bem-estar e o desempenho produtivo dos animais parasitados, resultando em significativas perdas econômicas (Alcaide et al., 2003), como redução no ganho em peso (Horak; Snijders, 1974) e diminuição de até $9 \%$ na produção de leite (Dorchies et al., 2003). No Brasil inexistem estimativas sobre os prejuízos econômicos causados pela oestrose na ovinocultura.

Os distúrbios causados por esse parasita começam no momento da postura das larvas, pois a mosca irrita os animais, que deixam de se alimentar para tentar proteger-se de seus ataques, escondendo o focinho no solo ou entre a lã de outros carneiros, balançando a cabeça e espirrando (Zumpt, 1965). Por sua vez, as larvas, pelos seus ganchos e espinhos, irritam e causam danos à mucosa nasal, provocando inflamação, acompanhada de produção de exsudato mucoso (Figura 73), que, além de dificultar a respiração, pode induzir infecções secundárias (Dorchies et al., 1998). O parasitismo pelas larvas de $O$. ovis causa rinite e sinusite nos animais, e o acúmulo de muco nasal e os espirros frequentes são os principais sinais clínicos da infestação pelas larvas desse parasita em ovinos e caprinos (Angulo-Valadez et al., 2011). 
Figura 73 - Ovelhas da raça Bergamacia com corrimento nasal mucopurulento, sinal clínico característico do parasitismo por larvas de Oestrus ovis
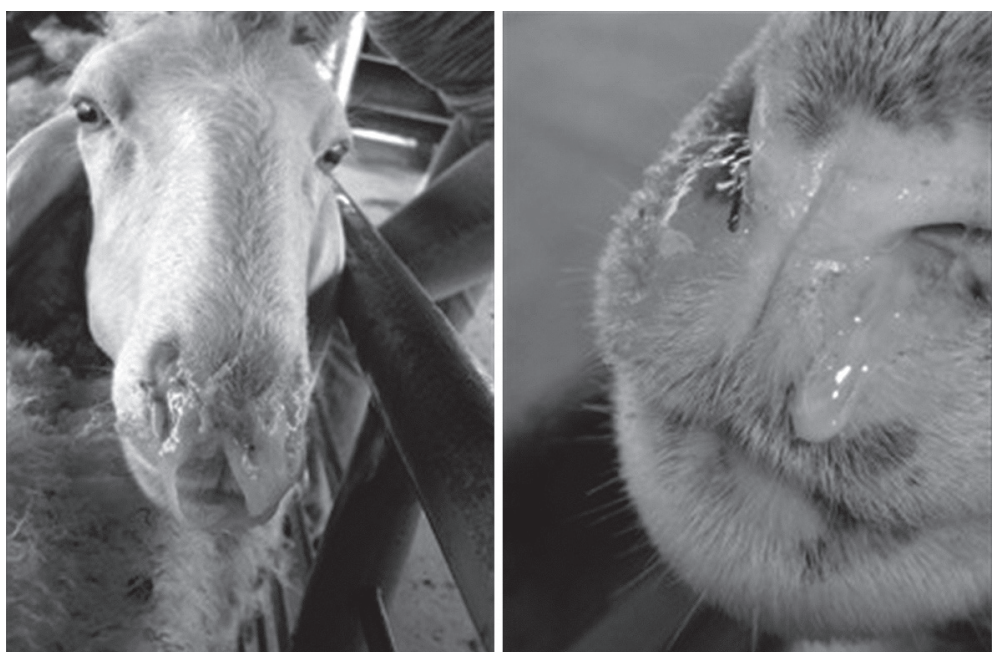

Vale ressaltar que, ao longo de três anos de estudos sobre $O$. ovis, apesar da elevada prevalência e intensidade de infestação, não foram observados ovinos com sintomatologia nervosa, pneumonia ou mortalidade de animais devido a oestrose (Silva et al., 2012a; 2012c). Além disso, embora em muitos casos seja observado um grande número de larvas parasitando os animais, nem todos apresentam sinais clínicos de oestrose (Angulo-Valadez et al., 2011; Silva et al., 2012a). Em contraste, alguns animais apresentam sinais clínicos severos, mesmo quando parasitados por poucas e até mesmo nenhuma larva de O. ovis (Angulo-Valadez et al., 2011). Esse fato é atribuído à variabilidade genética entre os animais, que tem influência nas reações imunológicas de hipersensibilidade (idem, 2008). Como exemplo, em um rebanho ovino de uma propriedade em Botucatu (SP), a porcentagem máxima de animais que apresentaram sinais clínicos durante os três anos de estudo foi de 20\% (Figura 74). No geral, os animais apresentaram sinais clínicos leves, como dispneia e corrimento nasal seroso (Silva, 2012).

Casos de mortalidade muitas vezes são atribuídos de forma indevida ao parasitismo por larvas de O. ovis. No geral, a evolução do 
parasitismo é benigna. Como as larvas são facilmente visualizadas e podem ser encontradas em grande número nos seios nasais e frontais dos animais parasitados, induzem os ovinocultores a atribuir a esses parasitas a mortalidade de ovinos. A causa da morte de ovinos decorre principalmente das infecções por outros patógenos, como o parasitismo por nematódeos gastrintestinais, que, apesar de apresentarem dimensão reduzida, o que dificulta a visualização, são muito mais patogênicos.

Figura 74 - Porcentagem média de ovinos que apresentaram sinais clínicos de oestrose em uma propriedade localizada em Botucatu (SP) (202 animais)

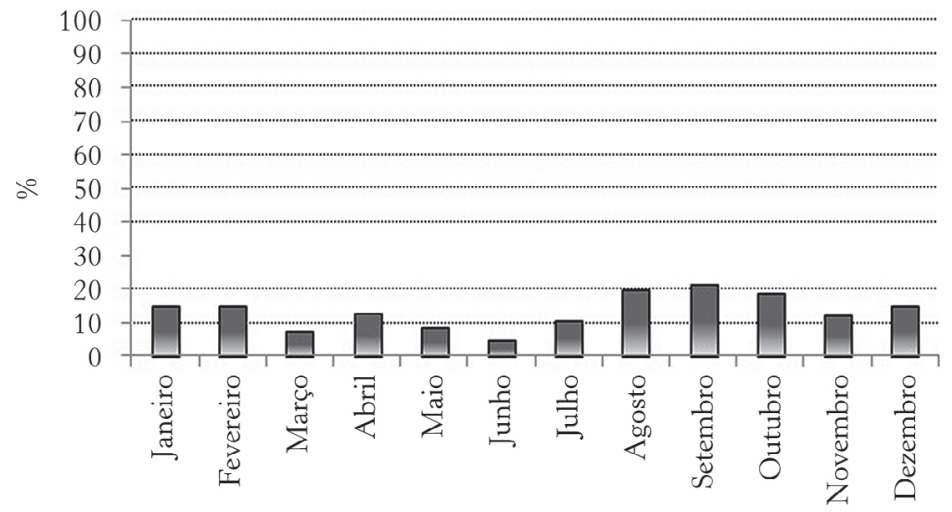

Médias obtida em três anos de estudo, adaptado de Silva (2012).

\section{Resposta imunológica}

As infecções parasitárias caracterizam-se por estimular inúmeros mecanismos imunológicos de defesa, sejam eles mediados por anticorpos ou por células, e a eficiência da resposta imunológica depende do parasita em questão e do estágio da infecção.

A presença das larvas de $O$. ovis na cavidade nasal dos ovinos induz resposta imunológica celular, com recrutamento de leucócitos (linfócitos T e B, macrófagos) e granulócitos (eosinófilos, mastócitos e leucócitos globulares) na mucosa do trato nasal, e resposta imune humoral local e sistêmica com produção de imunoglobulina $\mathrm{G}(\mathrm{IgG})$, imunoglobulina A ( $\operatorname{Ig} A)$ e imunoglobulina $\mathrm{E}(\operatorname{IgE})$, as quais são en- 
contradas no soro e/ou muco nasal dos ovinos parasitados (Tabouret et al., 2003b; Silva et al., 2012b; 2012c), o que sugere uma resposta imunológica tipo Th2 (Angulo-Valadez et al., 2011), similar ao que é observado na resposta imune contra o parasitismo por nematódeos gastrintestinais (Anthony et al., 2007; Rowe et al., 2008).

Em estudo realizado em Botucatu (SP), no período de setembro a dezembro de 2009, foi observado que os níveis séricos de IgG antiextrato bruto (Antígeno I) e produtos excretórios/secretórios (Antígeno II) de larvas de segundo estádio de O. ovis foram praticamente zero em cordeiros recém-desmamados, com dois meses de idade, provavelmente porque os animais não haviam tido contato prévio com o parasita. Porém, a partir do segundo mês de experimento, alguns cordeiros começaram a apresentar sinais clínicos de oestrose, coincidindo com o início do aumento gradativo dos níveis séricos de $\operatorname{IgG}$, que se estendeu até o fim do estudo (Figura 75). Na necropsia, larvas foram recuperadas de todos os animais, e foi observado que, paradoxalmente, quanto maior os níveis séricos de IgG anti-O. ovis, maior era o número de larvas recuperadas. $\mathrm{Ou}$ seja, a produção de imunoglobulinas aparentemente não conferiu proteção contra a infestação (Silva et al., 2012b).

Figura 75 - Níveis séricos médios de IgG antiextrato bruto de L2 de Oestrus ovis (Antígeno I) e antiprodutos excretórios e secretórios de L2 de O. ovis (Antígeno II) em cordeiros naturalmente infestados por larvas de $O$. ovis, no período de 23 de setembro de 2009 a 2 de dezembro de 2009

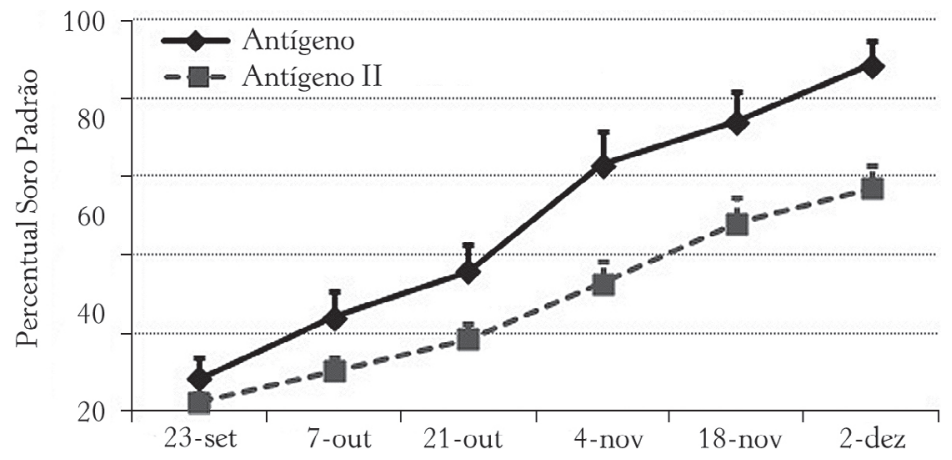

Barras $=$ erro padrão.

Adaptado de Silva et al. (2012b). 
Os principais sinais clínicos da infestação, tais como corrimento nasal e espirros frequentes, são imunologicamente mediados, ou seja, dependem da aquisição de imunidade do hospedeiro contra o parasita. Esses sintomas são mais intensos em alguns animais, o que é um indicativo de reação de hipersensibilidade, provocada provavelmente pelas moléculas excretadas e secretadas pelas larvas de O. ovis (Dorchies et al., 1998; Jacquiet et al., 2005). Em animais com esses sinais clínicos, as larvas, especialmente as L1 na cavidade nasal, podem ficar presas no muco, serem asfixiadas e expulsas do hospedeiro (Angulo-Valadez et al., 2011). Estudos sugerem que as larvas de O. ovis utilizam estratégias imunossupressoras, tais como inibição da proliferação de linfócitos específicos e degradação de imunoglobulinas, para evitar os mecanismos de defesa do hospedeiro (Tabouret et al., 2003a; Jacquiet et al., 2005; Duranton et al., 1999).

A resposta inflamatória causada pelas larvas de $O$. ovis parece estar relacionada com a regulação da carga parasitária, pois promove inibição no desenvolvimento larval (Frugère et al., 2000; Jacquiet et al., 2005). Como exemplo, a carga parasitária de O. ovis foi similar entre cordeiros Ile de France e Santa Inês, e todos os diferentes ínstares larvais foram recuperados de ambas as raças, porém, a proporção de L1 foi maior nos cordeiros da raça Santa Inês. Possivelmente, houve um retardo no desenvolvimento das larvas devido à resposta imunológica mais intensa dos animais Santa Inês, comparada aos Ile de France (Silva et al., 2012c). Além disso, foi observado que os linfócitos de ovinos previamente infestados não responderam à estimulação com antígenos específicos (produtos excretórios e secretórios de L2 e L3) após a terceira infestação. Ou seja, a capacidade de resposta dos linfócitos diminui de acordo com o número de exposições, sugerindo imunossupressão induzida pelo parasita (Jacquiet et al., 2005) ou, talvez, desenvolvimento de tolerância pelo hospedeiro.

Foi observado que em ovinos imunossuprimidos, que receberam tratamento com corticoide, o desenvolvimento larval foi mais rápido, comparado com o controle que não recebeu tratamento. Comparando o grupo imunossuprimido com o grupo de ovinos que 
haviam sido previamente parasitados pelas larvas, o estabelecimento larval foi similar, porém as larvas do grupo imunossuprimido tiveram peso mais elevado (ibidem). Vale ressaltar que O. ovis só se alimenta durante a fase de vida parasitária, enquanto larva, e, portanto, a redução do peso da larva madura pode comprometer a viabilidade da mosca (Cepeda-Palacios et al., 2000).

Portanto, esses estudos demonstram que, apesar de os ovinos sofrerem sucessivas infestações pelas larvas de $O$. ovis, a aquisição de resistência é pouco eficiente, oposto do que é observado no parasitismo por nematódeos gastrintestinais. Possivelmente, a interação parasita-hospedeiro é mais bem balanceada no caso de O. ovis, cuja infestação dos animais ocorre sem causar doença aguda, enquanto que é menos equilibrada nas infecções por nematódeos gastrintestinais, que frequentemente causam infecção aguda e morte em ovinos (Silva et al., 2012b). Porém, a resposta imunológica contra O. ovis pode ao menos manter o parasitismo sob relativo controle, regulando a carga parasitária ou afetando o crescimento das larvas, e, por consequência, a viabilidade das moscas.

\section{Epidemiologia}

Oestrus ovis é um parasita distribuído mundialmente, mas a atividade da mosca no ambiente, o desenvolvimento larval no aparelho nasal do hospedeiro, bem como o período de pupa, que ocorre no solo, sofrem grande influência das condições climáticas.

Os principais fatores climáticos que influenciam a atividade dos oestrídeos são a temperatura, luminosidade e velocidade do vento, mas no caso do O. ovis, a temperatura é fator determinante para a larviposição (Cepeda-Palacios; Scholl, 2000). Em Baja California Sur, México, onde a temperatura diurna durante a primavera varia entre $9^{\circ} \mathrm{C}$ e $35^{\circ} \mathrm{C}$, foi observado que a atividade da mosca teve início quando a temperatura mínima ultrapassou os $20^{\circ} \mathrm{C}$, mas a "temperatura ótima" para a larviposição variou entre $26^{\circ} \mathrm{C}$ e 28 ${ }^{\circ} \mathrm{C}$. Porém, O. ovis, por um processo adaptativo, pode ajustar-se às características climáticas da região onde habita, e essa "tempe- 
ratura ótima" pode ser diferente, dependendo da região estudada (ibidem). Mas, no geral, os ataques da mosca acontecem principalmente durante o período mais quente do dia.

Cobbett e Mitchell (1941) foram pioneiros em descrever a influência do clima na epidemiologia de O. ovis. Entre muitas descobertas, os pesquisadores observaram que durante o inverno o desenvolvimento larval na cavidade nasal dos animais é lento e que em locais onde o inverno é muito rigoroso, característico de regiões com clima temperado, a L1 cessa o desenvolvimento e entra em estado de hipobiose. Ou seja, não há desenvolvimento larval nesse período até que as condições climáticas voltem a ser favoráveis para o desenvolvimento. Da mesma forma, em países com clima muito quente, o desenvolvimento larval também é interrompido durante o período seco (Dorchies et al., 1998). Essa é uma das estratégias que podem assegurar a perpetuação do $O$. ovis em regiões em que as condições climáticas são extremas durante algum período do ano.

Devido a essa grande influência do clima no desenvolvimento das larvas de $O$. ovis, a prevalência e intensidade de infestação é variável de acordo com o país ou região estudada, como pode ser observado na Tabela 21, bem como a prevalência dos diferentes ínstares larvais recuperados da cavidade nasal dos animais parasitados.

Em locais com clima temperado, como a região sul da França (idem, 2000) e região nordeste da Espanha (Gracia et al., 2010), as L1 foram predominantes durante o ano de estudo, constituindo respectivamente $85,1 \%$ e $78,4 \%$ da carga parasitária total. O oposto foi observado na Sicilia, Itália (Caracappa et al., 2000) e na região sudeste da Espanha (Alcaide et al., 2003), onde todos os diferentes ínstares larvais foram simultaneamente recuperados durante o ano de estudo e em proporções similares. Na Sicilia, por exemplo, a proporção de L1, L2 e L3 foi respectivamente, 41,4\%, 29,1\% e $29,6 \%$, o que indica que as condições climáticas da região estudada foram favoráveis para o desenvolvimento larval. Porém, em ambos os estudos, durante os meses frios, foi observado um período de desenvolvimento lento, quando a proporção de L1 predominou sobre os demais estádios larvais. 
Tabela 21 - Prevalência e intensidade de infestação por larvas de Oestrus ovis em ovinos

\begin{tabular}{l|c|c|c|c}
\hline \multicolumn{1}{c|}{ Local } & N* & Prevalência & Intensidade & Referência \\
\hline Canadá & 698 & $50 \%$ & 2,5 & Fallis (1940) \\
\hline Estados Unidos & 720 & $91,5 \%$ & 25,6 & Meleney et al. (1962) \\
\hline Nova Zelândia & 1.083 & $65,8 \%$ & 3,1 & Kettle (1973) \\
\hline África do Sul & 542 & $73,4 \%$ & 15,2 & Horak (1977) \\
\hline Zimbábue & 507 & $21,9 \%$ & 1,1 & Pandey (1989) \\
\hline França (sudeste) & 555 & $65 \%$ & 24,8 & Yilma e Dorchies (1991) \\
\hline Itália (Sicilia) & 841 & $55,8 \%$ & 9,4 & Caracappa et al. (2000) \\
\hline França (sul) & 631 & $43,4 \%$ & 10,8 & Dorchies et al. (2000) \\
\hline Etiópia & 248 & $77,4 \%$ & 12,7 & Yilma e Genet (2000) \\
\hline Itália (Sardenha) & 566 & $91 \%$ & 19 & Scala et al. (2001) \\
\hline Espanha (sudeste) & 477 & $71,1 \%$ & 18,5 & Alcaide et al. (2003) \\
\hline Nigéria (norte) & 116 & $62,1 \%$ & 9,2 & Oniye et al. (2006) \\
\hline Turquia (Konya) & 624 & $59 \%$ & 23,9 & Uslu e Dik (2006) \\
\hline Turquia (Kars) & 387 & $40,3 \%$ & 4,5 & Arslan et al. (2009) \\
\hline Irã (Shiraz) & 2.002 & $49,7 \%$ & 6,3 & Shoorijeh et al. (2009) \\
\hline Espanha (nordeste) & 120 & $84,2 \%$ & 37,9 & Gracia et al. (2010) \\
\hline
\end{tabular}

* $\mathrm{N}$ = número de cabeças de ovinos examinadas, provenientes de abatedouros.

No Brasil, apesar da crescente observação de animais com sinais clínicos de oestrose, há poucos estudos epidemiológicos sobre essa enfermidade. Na região Sul foi observado que as condições climáticas foram favoráveis para a atividade da mosca de O. ovis e desenvolvimento larval na cavidade nasal dos ovinos em praticamente todos os meses do ano (Ribeiro et al., 1990; Ramos et al., 2006).

Em Bagé (RS), das 144 cabeças de ovinos examinadas durante o período de um ano, 85,4\% estavam parasitadas, e 1.639 larvas foram recuperadas, sendo que destas, 68,6\% eram L1; 12,3\%, L2; e 18,9\%, L3 (Ribeiro et al., 1990). Em Encruzilhada do Sul (RS), a prevalência foi de $100 \%$ em animais abatidos com sinais clínicos de oestrose, com intensidade média de infestação de 23,8 larvas/animal, e a prevalência de L1, L2 e L3 foi respectivamente de 78,9\%, 14, 5\% e 6,6\% (Oliveira et al., 1999). Já em estudo realizado em Santa Catarina, quando as temperaturas médias foram inferiores a $9,8^{\circ} \mathrm{C}$, não foram constatadas larvas de O. ovis em animais traçadores (Ramos et al., 2006). 
Pesquisas recentes sobre a epidemiologia de O. ovis foram realizadas no estado de São Paulo. Em Botucatu, foi observado que a evolução e desenvolvimento de $O$. ovis ocorre praticamente durante o ano inteiro, mas a infestação é mais frequente nos meses de primavera e verão (Figura 76). Nesse estudo, realizado durante três anos consecutivos, a intensidade média de infestação em cordeiros foi de 16,8 larvas/cabeça, com média de 7,8, L1; 5,3, L2; e 3,7, L3 (Silva et al., 2012a). Larvas de O. ovis também foram recuperadas de ovinos criados em Itápolis, Ibitinga, Borborema, Guarantã e Tapinas, municípios da região central do estado de São Paulo (idem, 2013). Na região norte do Mato Grosso também foi registrada a ocorrência de animais com sinais clínicos de oestrose, e larvas foram recuperadas dos ovinos necropsiados (Schenkel et al., 2012).

Figura 76 - Número médio de larvas de Oestrus ovis recuperadas de cordeiros traçadores em Botucatu (SP)

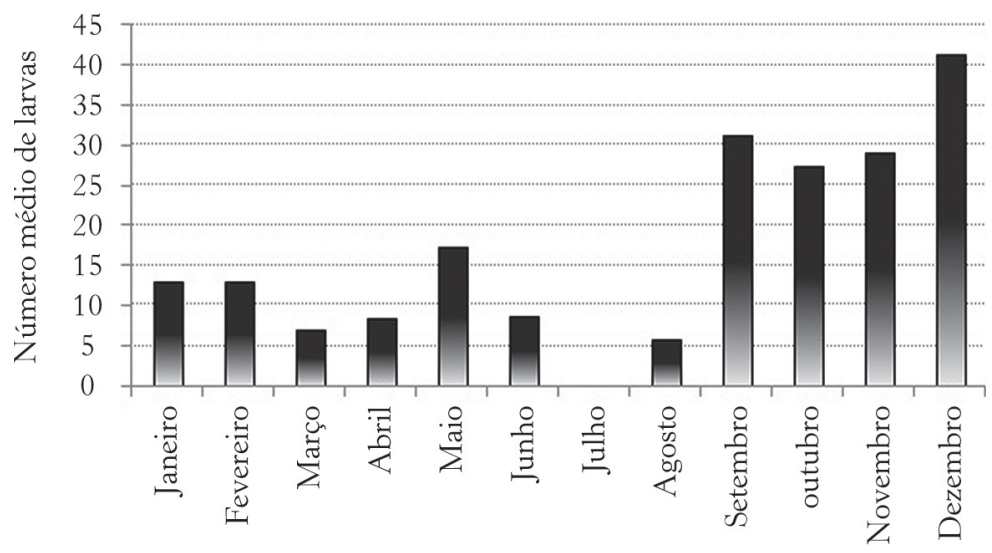

Médias referentes a três anos de estudo, adaptado de Silva et al. (2012a).

\section{Soroprevalência}

No geral, o diagnóstico de oestrose é baseado em sinais clínicos e na detecção das larvas post mortem, porém, estudos demonstram que o teste ELISA (Enzyme-Linked Immunosorbent Assay)é sensível para 
detecção de anticorpos específicos anti-O. ovis, utilizando antígenos totais ou produtos excretórios e secretórios das larvas (Papadopoulos et al., 2001; Alcaide et al., 2005a; Angulo-Valadez et al., 2008).

Alguns estudos, além de avaliarem a prevalência por sorologia, também avaliaram fatores de risco associados com a oestrose. Em Yucatan, México, 30\% dos ovinos avaliados estavam soropositivos para O. ovis, e o tamanho do rebanho ( $>25$ animais) e a cor do focinho do ovino (escuro) foram associados como fatores de risco para a ocorrência da enfermidade (Murguia et al., 2000). Já na região sudeste da Alemanha, a prevalência de anticorpos foi de $50 \%$ nos ovinos examinados, e o tamanho do rebanho (> 50 animais) foi o único fator de risco associado com a oestrose (Bauer et al., 2002).

De 551 fazendas estudadas na região sudeste da Espanha, apenas dezoito estavam livres de animais soropositivos, e em 115 todos os animais foram soropositivos para $O$. ovis. A prevalência média de animais soropositivos foi de $69,3 \%$, e foi observado que o tamanho do rebanho ( $>250$ ovinos) e a densidade da população ovina $\left(>100\right.$ ovinos por $\mathrm{km}^{2}$ ) foram importantes fatores de risco para a ocorrência desse parasita na região estudada (Alcaide et al., 2005b).

\section{Ovino x Caprino}

Tanto ovinos como caprinos são parasitados por O. ovis, mas a prevalência do parasitismo é menor nos caprinos do que em ovinos. Em Pézenas, região sul da França, a prevalência, os sinais clínicos da infestação e a carga parasitária de O. ovis foram menores em caprinos do que em ovinos (Dorchies et al., 2000). Da mesma forma, na Grécia, a prevalência de animais com anticorpos específicos anti-O. ovis foi menor em caprinos, comparada aos ovinos (Papadopoulos et al., 2001; 2006).

Há algumas hipóteses para essa diferença no parasitismo por $O$. ovis entre caprinos e ovinos. Supõe-se que os caprinos sejam mais sensíveis aos ataques da mosca e que consigam evitar o contato com esta de forma mais eficiente do que os ovinos (Dorchies et al., 1998; Angulo-Valadez et al., 2010). Acredita-se também que a relação parasita-hospedeiro seja mais antiga entre caprinos e O. ovis, em 
comparação com ovinos. Esse período mais longo de coevolução talvez tenha tornado os caprinos mais bem adaptados ao parasitismo (Angulo-Valadez et al., 2010).

\section{Interação entre a infestação por O. ovis e a infecção por nematódeos gastrintestinais}

Comumente os animais são parasitados por vários organismos simultaneamente. Esse é o caso dos ovinos, que usualmente são parasitados por nematódeos gastrintestinais e por larvas de O. ovis. Vários trabalhos foram realizados a fim de avaliar a interação entre a infestação por larvas de $O$. ovis e as infecções com nematódeos gastrintestinais, como a interação entre $O$. ovis e o parasita do intestino delgado Trichostrongylus colubriformis (Yacob et al., 2002; 2004; 2006) ou o parasita do abomaso Haemonchus contortus (Dorchies et al., 1997b; Terefe et al., 2005).

Nesses trabalhos, os ovinos foram divididos em quatro grupos de animais: infectados apenas com larvas de O. ovis; infectados apenas com nematódeo gastrintestinal (T. colubriformis ou H. contortus); ovinos infectados com ambos os parasitas; e grupo-controle, que permaneceu livre de infestações/infecções pelos referidos parasitas. Os pesquisadores observaram que a infecção no trato digestivo por nematódeos não modificou a biologia da população de Oestrus na cavidade nasal. Já a presença do O. ovis foi relacionada com significativa redução na eliminação de ovos pelos helmintos, redução no tamanho e fecundidade das fêmeas e na carga parasitária. Essas mudanças foram associadas com eosinofilia e significativas modificações na população tecidual de mastócitos, leucócitos e eosinófilos nos tratos respiratório e digestivo. Com base nesses resultados, foi observado que a infecção parasitária em uma determinada região anatômica provoca "a distância" reações inflamatórias em todo o sistema de mucosa, pois foram observadas mudanças na população celular tecidual em região anatômica que não estava parasitada.

Cordeiros das raças Ile de France e Santa Inês também apresentaram menor carga parasitária de vermes quando naturalmente infestados por larvas de O. ovis (Silva et al., 2012c). Porém, apesar 
de existir correlação negativa entre o parasitismo por $O$. ovis e nematódeos gastrintestinais, a regulação é de natureza transitória e desaparece quando as larvas de O. ovis são expelidas pelo hospedeiro ou após tratamento com antiparasitário. O mecanismo envolvido na regulação não é específico e está relacionado com forte ativação dos eosinófilos sanguíneos que agem de forma inespecífica sobre os vermes (Yacob et al., 2006).

\section{Profilaxia}

O controle do parasitismo por $O$. ovis é feito exclusivamente com o uso de antiparasitários, tais como os organofosforados (triclorfon), closantel e as lactonas macrocíclicas, como a ivermectina (Dorchies et al., 1997a; Lucientes et al., 1998), moxidectina (Dorchies et al., 1996), doramectina (Oliveira et al., 2000; Dorchies et al., 2001), eprinomectina (Hoste et al., 2004; Habela et al., 2006) e também rafoxanida (Sanyal et al., 1986) e nitroxinil.

\section{Considerações finais}

Apesar da elevada prevalência e intensidade de infestação observada mundialmente, a oestrose pode ser considerada uma enfermidade de caráter benigno. Porém, existe grande carência de estudos sobre o impacto da oestrose na produtividade dos ovinos parasitados. São poucos os estudos epidemiológicos sobre esse parasita no Brasil, e apenas com tal conhecimento é possível predizer quais os fatores climáticos que favorecem a infestação, bem como recomendar a melhor estratégia para a profilaxia da enfermidade.

\section{Referências bibliográficas}

\section{Cochliomyia hominivorax}

AMARANTE, A. F. T. et al. Epidemiology of Sheep Myiases in São Paulo State, Brazil. Trop. Anim. Health Prod., [s. 1.], v.24, p.36-9, 1992. 
ANZIANI, O. S.; GUGLIELMONE, A. A.; SCHMID, H. Efficacy of Dicyclanil in the Prevention of Screwworm Infestation (Cochliomyia hominivorax) in Cattle Castration Wounds. Vet. Parasitol., [s. 1.], v.76, p.229-32, 1998.

et al. Persistent Activity of Doramectin and Ivermectin in the Prevention of Cutaneous Myiasis in Cattle Experimentally Infested with Cochliomyia hominivorax. Vet. Parasitol., [s. 1.], v.87, p.243-7, 2000.

BENITEZ, C. U. et al. Prophylactic Use of Ivermectin Against Cattle Myiasis Caused by Cochliomyia hominivorax (Coquerel, 1858). Vet. Parasitol., [s. 1.], v.72, p.215-20, 1997.

CAPRONI JR, L. et al. Persistent Efficacy of Doramectin and Ivermectin in the Prevention of Natural Cochliomyia hominivorax Infestations in Cattle Castrated 10 Days After Treatment. Rev. Bras. Parasitol. Vet., [s. 1.], v.7, p.57-61, 1998.

CORREIA, T. R. et al. Larvicidal Efficacy of Nitenpyram on the Treatment of Myiasis Caused by Cochliomyia hominivorax (Diptera: Calliphoridae) in Dogs. Vet. Parasitol., [s. 1.], v.173, p.169-72, 2010.

GRISI, L. et al. Impacto econômico das principais ectoparasitoses em bovinos no Brasil. A Hora Veterinária, [s. 1.], v.125, p.8-10, 2002.

GUIMARÃES, J. H.; PAPAVERO, N.; PRADO, A. P. As miíases na região Neotropical (identificação, biologia, bibliografia). Rev. Bras. Zool., [s. 1.], v.1, p.239-416, 1983.

HALL, M.; WALL, R. Myiasis of Humans and Domestic Animals, In: J. R.; BAKER|, R. M.; ROLLINSON, D. (eds.). Advances in Parasitology. [S. 1.]: Academic Press, 1995, p.257-334.

HALL, M. J. R. Screwworm Flies as Agents of Wound Myiasis. World Animal Review (FAO), [s. 1.], p.8-17, 1991.

LELLO, E.; PINHEIRO, F. A.; NOCE, O. F. Epidemiologia de miíases no município de Botucatu, S.P. Brasil. Arq. Esc. Vet. UFMG, [s. 1.], v.34, p.93-108, 1982.

LINHARES, A. X. Miíases. In: NEVES, D. P. (ed.). Parasitologia humana. 10.ed. [S. 1.]: Atheneu, 2000, p.350-8.

LIMA, W. S. et al. Evaluation of the Prophylactic Effect and Curative Efficacy of Fipronil 1\% Pour on (Topline ${ }^{\circledR}$ ) on Post-Castration Scrotal Myiasis Caused by Cochliomyia hominivorax in Cattle. Vet. Parasitol., [s. 1.], v.125, p.373-7, 2004.

MADEIRA, N. G.; AMARANTE, A. F. T.; PADOVANI, C. R. Effect of Management Practices on Screw-Worm among Sheep in São Paulo State, Brazil. Trop. Anim. Health Prod., [s. 1.], v.30, p.149-57, 1998. 
MORAIS, M. C. et al. Alterações clínicas em bovinos infestados experimentalmente com larvas de Cochliomyia hominivorax (Coquerel, 1858) (Diptera: Calliphoridae). Rev. Bras. Parasitol. Vet., [s. 1.], v.12, p.154-8, 2003.

MOYA-BORJA, G. E. Erradicação ou manejo integrado das miíases neotropicais das Américas? Pesq. Vet. Bras., [s. 1.], v.23, p.131-8, 2003. et al. Prophylactic and Persistent Efficacy of Doramectin Against Cochliomyia hominivorax in Cattle. Vet. Parasitol., [s. 1.], v.49, p.95105, 1993.

et al. Protective Efficacy of Doramectin and Ivermectin Against Cochliomyia hominivorax. Vet. Parasitol., [s. 1.], v.72, p.101-9, 1997.

MUNIZ, R. A. et al. Efficacy of Doramectin in the Protection of Neonatal Calves and Post-Parturient Cows Against Field Strikes of Cochliomyia hominivorax. Vet. Parasitol., [s. 1.], v.58, p.155-61, 1995a.

et al. Efficacy of Injectable Doramectin in the Protection of Castrated Cattle Against Field Infestations of Cochliomyia hominivorax. Vet. Parasitol., [s. 1.], v.58, p.327-33, 1995b.

OLIVEIRA, C. M. B. Desenvolvimento das pré-pupas e das pupas de Cochliomyia hominivorax (Coquerel, 1858) no Rio Grande do Sul. Arq. Fac. Vet. UFRGS, [s. 1.], v.14, p.87-92, 1986a.

Flutuação populacional de Cochliomyia hominivorax (Coquerel, 1858)em Porto Alegre. Arq. Fac. Vet. UFRGS, [s. 1.], v.14, p.93-7, 1986 b.

RAHN, J. J.; BARGER, G. L. Weather Conditions and Screwworm Activity. Agr. Meteorol., [s. 1.], v.11, p.197-211, 1973.

ROBINSON, A. S. et al. Enabling Technologies to Improve Area-Wide Integrated Pest Management Programmes for the Control of Screwworms. Med. Vet. Entomol., [s. 1.;], v.23, p.1-7, 2009.

SANAVRIA, A. et al. Eficácia profilática de doramectin contra infestações naturais por Cochliomyia hominivorax (Coquerel, 1858) em bovinos após a castração. Rev. Bras. Parasitol. Vet., [s. 1.], v.5, p.7-10, 1996.

STUART, M. A. et al. Determination of a Relationship between Soil Moisture and Screwworm Fly (Diptera: Calliphoridae) Activity. Aust. J. Entomol., [s. 1.], v.34, p.1-5, 1995.

THOMAS, D. B. Behavioral Aspects of Screwworm Ecology. J. Kans. Entomol. Soc., [s. 1.], v.66, p.13-30, 1993.

VARGAS-TERÁN, M.; HOFMANN, H. C.; TWEDDLE, N. E. Impact of Screwworm Eradication Programmes Using the Sterile Insect Technique, In: DYCK, V. A.; HENDRICHS, J.; ROBINSON, A. S. (eds.). Sterile Insect Technique. Springer Netherlands, p.629-50, 2005. 


\section{Dermatobia hominis}

AMARANTE, A. F. T. et al. Epidemiology of Sheep Myiases in São Paulo State, Brazil. Trop. Anim. Health Prod., [s. 1.], v.24, p.36-9, 1992. BANEGAS, A. D.; MOURIER, H. Laboratory Observations on the Life History and Habits of Dermatobia hominis (Diptera: Cuterebridae). I. Mating Behavior. Ann. Entomol. Soc. Am., [s. 1.], v.60, p.878-81, 1967. BANEGAS, A. D.; MOURIER, H.; GRAHAM, O. H. Laboratory Colonization of Dermatobia hominis (Diptera: Cuterebridae). Ann. Entomol. Soc. Am., [s. 1.], v.60, p.511-4, 1967.

BARBOSA, C. G.; SANAVRIA, A.; BARBOSA, M. D. P. R. C. Fase parasitária e alterações clínicas em bovinos infestados experimentalmente com larvas de Dermatobia hominis (Diptera: Cuterebridae). Parasitol. Latinoam., [s. 1], v.57, p.15-20, 2002.

Alterações hematológicas em bovinos infestados experimentalmente com larvas de Dermatobia hominis (Diptera: Cuterebridae). Rev. Bras. Parasitol. Vet., [s. 1.], v.12, p.61-7, 2003.

BATES, M. Mosquitoes as vectors of Dermatobia hominis in Eastern Colombia. Ann. Entomol. Soc. Am., [s. 1.], v.36, p.21-4, 1943.

BELLATO, V. et al. Variação sazonal das larvas da mosca do berne em bovinos no Planalto Catarinense. Comunicado Técnico EMPASC, [s. 1.], v.101, p.1-7, 1986.

BORGES, F. A. et al. Endectocide Activity of a New Long-Action Formulation Containing 2.25\% ivermectin $+1.25 \%$ Abamectin in Cattle. Vet. Parasitol., [s. 1.], v.155, p.299-307, 2008.

BRITO, G. L.; MOYA-BORJA, G. E. Flutuação sazonal de Dermatobia hominis em peles bovinas oriundas de matadouro. Pesq. Agropec. Bras., [s. 1.], v.20, p.151-4, 2000.

; PAES, M. J.; MOYA-BORJA, G. E. Infestação artificial e desenvolvimento larval de Dermatobia hominis (L. Jr., 1781) (Diptera: Cuterebridae) em suínos e equinos. Rev. Ceres, [s. 1.], v.48, p.401-3, 2001.

CATTS, E. P. Biology of New World Bot Flies: Cuterebridae. Annu. Rev. Entomol., [s. 1.], v.27, p.313-38, 1982.

COGLEY, T. P.; COGLEY, M. C. Morphology of the Eggs of the Human Bot Fly, Dermatobia hominis (L. Jr.) (Diptera : Cuterebridae) and Their Adherence to the Transport Carrier. Int. J. Insect Morphol. Embryol., [s. 1.], v.18, p.239-48, 1989.

FERNANDES, N. L. M. et al. Dinâmica populacional e distribuição corporal das larvas de Dermatobia hominis (Linnaeus Jr., 1781) em bovinos da raça nelore. Arch. Vet. Sci., [s. 1.], v.13, p.85-92, 2008. 
GOMES, A. et al. Vetores de ovos de Dermatobia hominis (L. Jr. 1781) (Diptera: Cuterebridae) na região de Cerrados do Mato Grosso do Sul, Brasil. Rev. Bras. Parasitol. Vet., [s. 1.], v.7, p.37-40, 1998.

GRISI, L. et al. Impacto econômico das principais ectoparasitoses em bovinos no Brasil. A Hora Veterinária, [s. 1.], v.125, p.8-10, 2002.

GUIMARÃES, J. H.; PAPAVERO, N.; PRADO, A. P. As miíases na região Neotropical (Identificação, Biologia, Bibliografia). Rev. Bras. Zool., [s. 1.], v.1, p.239-416, 1983.

HALL, M.; WALL, R. Myiasis of Humans and Domestic Animals, In: BAKER, J. R.; MULLER, R.; ROLLINSON, D. (eds.). Advances in Parasitology. [S. 1.]: Academic Press, 1995, p.257-334.

KOONE, H. D.; BANEGAS, A. D. Biology and Control of Dermatobia hominis (L. Jr.) in Honduras (Diptera: Cuterebridae). J. Kans. Entomol. Soc., [s. 1.], v.32, p.100-8, 1959.

LEITE, R. C. et al. Eficácia de doramectin contra infestações naturais por larvas de Dermatobia hominis em bovino. Rev. Bras. Parasitol. Vet., [s. 1.], v.5, p.107-11, 1996.

et al. Efficacy and Persistence of Doramectin and Ivermectin Against Natural Infestations of Dermatobia hominis Larvae in Cattle in Minas Gerais. Rev. Bras. Parasitol. Vet., [s. 1.], v.8, p.161-6, 1999.

LELLO, E.; DE ROSIS, A. M. B. Inflammatory Reaction to the Human Bot-Fly, Dermatobia hominis, in Infested and Reinfested Mice. Med. Vet. Entomol., [s. 1.], v.17, p.55-60, 2003.

.; PINHEIRO, F. A.; NOCE, O. F. Epidemiologia de míases no município de Botucatu, S.P. Brasil. Arq. Esc. Vet. UFMG, [s. l.], v.34, p.93-108, 1982.

; TOLEDO, L. A.; GREGÓRIO, E. A. Diferenciação morfológica das gônadas em larvas de Dermatobia hominis (Diptera: Cuterebridae). Mem. Inst. Oswaldo Cruz, [s. 1.], v.79, p.211-9, 1984.

OLIVEIRA-SEQUEIRA, T. C. G.; PERAÇOLI, M. T. S. Inflamatory Response in Dermatobia hominis Infested Rabbits. Rev. Bras. Parasitol. Vet., [s. 1.], v.8, p.87-91, 1999.

MADEIRA, N. G.; AMARANTE, A. F. T.; PADOVANI, C. R. Effect of Management Practices on Screw-Worm Among Sheep in São Paulo State, Brazil. Trop. Anim. Health Prod., [s. 1.], v.30, p.149-57, 1998.

Diversity of Ectoparasites in Sheep Flocks in São Paulo, Brazil. Trop. Anim. Health Prod., [s. 1.], v.32, p.225-32, 2000.

MARSDEN, P. D.; SHELLEY, A. J.; ARMITAGE, P. The Number of Dermatobia hominis Lesions in Zebu Cow Hides of Different Colours. Trans. R. Soc. Trop. Med. Hyg., [s. 1.], v.73, p.458-9, 1979. 
MOYA-BORJA, G. E. Erradicação ou manejo integrado das miíases neotropicais das Américas? Pesq. Vet. Bras., [s. 1.], v.23, p.131-8, 2003. et al. Therapeutic and Persistent Efficacy of Doramectin Against Dermatobia hominis in Cattle. Vet. Parasitol., [s. 1.], v.49, p.85-93, 1993.

MOZZAQUATRO, F. D.; SANAVRIA, A. Estudo epidemiológico da Dermatobia hominis (Diptera: Cuterebridae) em bovinos de produção leiteira no Município de Santa Maria, Rio Grande do Sul, Brasil. Parasitol. Latinoam., [s. 1.], v.58, p.80-2, 2003.

MUNIZ, R. A. et al. Efficacy of Injectable Doramectin in the Therapy and Control of Dermatobia hominis Infestations in Latin America. Vet. Parasitol., [s. 1.], v.60, p.265-71, 1995.

OLIVEIRA, G. P. Ecologia de Dermatobia hominis L. Jr. 1781 (Diptera: Cuterebridae) na região de São Carlos, Estado de São Paulo, Brasil. TURRIALBA, [s. 1.], v.41, p.367-75, 1991.

OLIVEIRA-SEQUEIRA, T. C. G. et al. Histological and Immunological Reaction of Cattle Skin to First-Instar Larvae of Dermatobia hominis. Med. Vet. Entomol., [s. 1.], v.10, p.323-30, 1996.

PINTO, S. B. et al. Bioecologia de Dermatobia hominis (Linnaeus Jr., 1781) em Palotina, Paraná. Brasil. Cienc. Rural, [s. 1.], v.32, p.821-7, 2002.

RIBEIRO, P. B.; OLIVEIRA, C. M. B. Fase parasitária de Dermatobia hominis (L. Jr., 1781) (Diptera: Cuterebridae) sobre bovinos. Arq. Bras. Med. Vet. Zootec., [s. 1.], v.35, p.691-8, 1983.

. Fases de vida livre da Dermatobia hominis (L. Jr., 1781)

(Diptera: Cuterebridae). Arq. Bras. Med. Vet. Zootec., [s. 1.], v.39, p.881-90, 1987.

et al. Foréticos da Dermatobia hominis (L. Jr., 1781) (Diptera: Cuterebridae), no Rio Grande do Sul, Brasil. Arq. Bras. Med. Vet. Zootec., [s. 1.], v.37, p.507-9, 1985.

RONCALLI, R. A. The Biology and the Control of Dermatobia hominis, the Tropical Warble-Fly of Latin America. Prev. Vet. Med., [s. 1.], v.2, p.569-78, 1984.

; USHER, C. B. Efficacy of Ivermectin Against Dermatobia hominis in Cattle. Vet. Parasitol., [s. 1.], v.28, p.343-6, 1988.

SANAVRIA, A. et al. Distribuição e frequência de larvas de Dermatobia hominis (Linnaeus Jr., 1781) (Diptera: Cuterebridae) em peles de bovinos. Parasitol. Latinoam., [s. 1.], v.57, p.21-4, 2002.

SANCHO, E. Dermatobia, the Neotropical Warble Fly. Parasitol. Today, [s. 1.], v.4, p.242-6, 1988. 


\section{Oestrus ovis}

ALCAIDE, M. et al. Seasonal Variations in the Larval Burden Distribution of Oestrus ovis in Sheep in the Southwest of Spain. Vet. Parasitol., [s. 1.], v.118, p.235-41, 2003.

et al. Analysis of Larval Antigens of Oestrus ovis for the Diagnosis of Oestrosis by Enzyme-Linked Immunosorbent Assay. Med. Vet. Entomol., [s. 1.], v.19, p.151-7, 2005a.

et al. Seroprevalence of Oestrus ovis (Diptera, Oestridae) Infestation and Associated Risk Factors in Ovine Livestock from Southwestern Spain. J. Med. Entomol., [s. 1.], v.42, p.327-31, 2005b.

ANGULO-VALADEZ, C. E. et al. Specific IgG Antibody Responses in Oestrus ovis L. (Diptera: Oestridae) Infected Sheep: Associations with Intensity of Infection and Larval Development. Vet. Parasitol., [s. 1.], v.155, p.257-63, 2008. et al. Nasal Bots... a Fascinating World! Vet. Parasitol., [s. 1.], v.174, p.19-25, 2010.

et al. Sheep and Goat Immune Responses to Nose Bot Infestation: a Review. Med. Vet. Entomol., [s. 1.], v.25, p.117-25, 2011.

ANTHONY, R. M. et al. Protective Immune Mechanisms in Helminth Infection. Nat. Rev. Immunol., [s. 1.], v.7, p.975-87, 2007.

ARSLAN, M.; KARA, M.; GICIK, Y. Epidemiology of Oestrus ovis Infestations in Sheep in Kars Province of North-Eastern Turkey. Trop. Anim. Health Prod., [s. 1.], v.41, p.299-305, 2009.

BAUER, C. et al. Seroprevalence of Oestrus ovis Infection in Sheep in Southwestern Germany. Vet. Parasitol., [s. 1.], v.110, p.137-43, 2002.

CARACAPPA, S. et al. Epidemiology of Ovine Oestrosis (Oestrus ovis Linné 1761, Diptera: Oestridae) in Sicily. Vet. Parasitol., [s. 1.], v.92, p.233-7, 2000.

CEPEDA-PALACIOS, R.; SCHOLL, P. J. Factors Affecting the Larvipositional Activity of Oestrus ovis Gravid Females (Diptera: Oestridae). Vet. Parasitol., v.91, p.93-105, 2000.

; FRUGËE, S.; DORCHIES, P. Expected Effects of Reducing Oestrus ovis L. Mature Larval Weight on Adult Populations. Vet. Parasitol., [s. 1.], v.90, p.239-46, 2000.

et al. Estimation of the Growth Patterns of Oestrus ovis L. Larvae Hosted by Goats in Baja California Sur, Mexico. Vet. Parasitol., [s. 1.], v.86, p.119-26, 1999.

COBBETT, N. G.; MITCHELL, W. C. Further Observations on the Life Cycle and Incidence of the Sheep Bot, Oestrus ovis, in New Mexico and Texas. Am. J. Vet. Res., [s. 1.], v.2, p.358-66, 1941. 
DORCHIES, P.; CARDINAUD, B.; FOURNIER, R. Efficacy of Moxidectin as a $1 \%$ Injectable Solution and a $0.1 \%$ Oral Drench Against Nasal Bots, Pulmonary and Gastrointestinal Nematodes in Sheep. Vet. Parasitol., [s. 1.], v.65, p.163-8, 1996.

; ALZIEU, J. P.; CADIERGUES, M. C. Comparative Curative and Preventive Efficacies of Ivermectin and Closantel on Oestrus ovis (Linné 1758) in Naturally Infected Sheep. Vet. Parasitol., v.72, p.17984, 1997a.

; DURANTON, C.; JACQUIET, P. Pathophysiology of Oestrus ovis Infection in Sheep and Goats: a Review. Vet. Rec., [s. 1.], v.142, p.487-9, 1998.

et al. Reduced Egg Counts in Mixed Infections with Oestrus ovis and Haemonchus contortus: Influence of Eosinophils? Parasitol. Res., [s. 1.], v.83, p.727-30, 1997b.

et al. Prevalence and Larval burden of Oestrus ovis (Linné 1761) in Sheep and Goats in Northern Mediterranean Region of France. Vet. Parasitol., [s. 1.], v.88, p.269-73, 2000.

et al. Efficacy of Doramectin Injectable Against Oestrus ovis and Gastrointestinal Nematodes in Sheep in the Southwestern Region of France. Vet. Parasitol., [s. 1.], v.96, p.147-54, 2001.

et al. The Relationship between Nasal Myiasis and the Prevalence of Enzootic Nasal Tumours and the Effects of Treatment of Oestrus ovis and Milk Production in Dairy Ewes of Roquefort Cheese Area. Vet. Parasitol., [s. 1.], v.113, p.169-74, 2003.

DURANTON, C. et al. Changing Reactivity of Caprine and Ovine Mononuclear Phagocytes throughout Part of the Life Cycle of Oestrus ovis: Assessment Through Spontaneous and Inductible NO Production. Vet. Res., [s. 1.], v.30, p.371-6, 1999.

FALLIS, A. M. Studies on Oestrus ovis L. Can. J. Res., [s. 1.], v.18, p.442-6, 1940.

FRUGÈRE, S. et al. Immunisation of Lambs with Excretory Secretory Products of Oestrus ovis Third Instar Larvae and Subsequent Experimental Challenge. Vet. Res., [s. 1.], v.31, p.527-35, 2000.

GRACIA, M. J. et al. Epidemiology of Oestrus ovis Infection of Sheep in Northeast Spain (Mid-Ebro Valley). Trop. Anim. Health Prod., [s. 1.], v.42, p. 811-3, 2010.

HABELA, M. et al. Efficacy of Eprinomectin Pour-on in Naturally Oestrus ovis Infested Merino Sheep in Extremadura, South-West Spain. Parasitol. Res., [s. 1.], v.99, p.275-80, 2006. 
HALL, M.; WALL, R. Myiasis of Humans and Domestic Animals, In: BAKER, J. R.; MULLER, R.; ROLLINSON, D. (eds.). Advances in Parasitology. Academic Press, pp. 257-334, 1995.

HORAK, I. G. Parasites of Domestic and Wild Animals in South Africa. I. Oestrus ovis in Sheep. Onderstepoort J. Vet. Res., [s. 1.], v.44, p.55-64, 1977.

; SNIJDERS, A. J. The Effect of Oestrus ovis Infestation on Merino Lambs. Vet. Rec., [s. 1.], v.94, p.12-6, 1974.

HOSTE, H. et al. Efficacy of Eprinomectin Pour-on Against Gastrointestinal Nematodes and the Nasal Bot Fly (Oestrus ovis) in Sheep. Vet. Rec., [s. 1.], v.154, p.782-5, 2004.

JACQUIET, P. et al. Regulation of Oestrus ovis (Diptera: Oestridae) Populations in Previously Exposed and Naive Sheep. Vet. Immunol. Immunopathol., [s. 1.], v.105, p.95-103, 2005.

KETTLE, P. R. A Study on the Sheep Botfly, Oestrus ovis (Diptera: Oestridae) in New Zealand. N. Z. Entomol., [s. 1.], v.5, p.185-91, 1973.

LUCIENTES, J. et al. Efficacy of Orally Administered Ivermectin Against Larval Stages of Oestrus ovis in Sheep. Vet. Parasitol., [s. 1.], v.75, p.255-9, 1998.

MELENEY, W. P.; COBBETT, N. G.; PETERSON, H. O. The Natural Occurrence of Oestrus ovis in Sheep from the Southwestern United States. Am. J. Vet. Res., [s. 1.], v.23, p.1246-51, 1962.

MURGUIA, M. et al. Detection of Oestrus ovis and Associated Risk Factors in Sheep from the Central Region of Yucatan, Mexico. Vet. Parasitol., [s. 1.], v.88, p.73-8, 2000.

OLIVEIRA, C. M. B.; OLIVEIRA, L. O.; TORRES, J. R. Oestrus ovis larvae distribution in the head of naturally infested sheep. Arq. Fac. Vet. UFRGS, v.27, p.87-92, 1999.

et al. Efficacy of Doramectin in the Treatment of Sheep Naturally Infested by Oestrus ovis. Rev. Bras. Parasitol. Vet., [s. 1.], v.9, p.61-4, 2000.

ONIYE, S.; ADEBOTE, D.; AHUNANYA, C. Observations on Oestrus ovis L.(Diptera: Oestridae) Myiasis in the Nasal Cavities and Sinuses of the Domestic Sheep (Ovis aries) in Zaria, Northern Nigeria. Int. J. Zool. Res., [s. 1.], v.2, p.178-85, 2006.

PANDEY, V. S. Epidemiology of Oestrus ovis Infection of Sheep in the Highveld of Zimbabwe. Vet. Parasitol., [s. 1.], v.31, p.275-80, 1989.

PAPADOPOULOS, E. et al. Seasonal Variation of Oestrus ovis-Specific Antibodies in Sheep and Goats Mixed Flocks in Greece. Vet. Parasitol., [s. 1.], v.95, p.73-7, 2001. 
et al. Comparison of Infection Rates of Oestrus ovis between Sheep and Goats Kept in Mixed Flocks. Vet. Parasitol., [s. 1.], v.138, p.382-5, 2006.

RAMOS, C. I. et al. Epidemiologia de Oestrus ovis (Diptera: Oestridae) em ovinos no Planalto Catarinense. Cienc. Rural, [s. 1.], v.36, p.173-8, 2006.

RIBEIRO, V. L. S.; OLIVEIRA, C. M. B.; BRANCO, F. P. J. A. Prevalência e variações mensais das larvas de Oestrus ovis (Linneus, 1761) em ovinos no município de Bagé, RS. Brasil. Arq. Bras. Med. Vet. Zootec., [s. 1.], v.42, p.211-21, 1990.

ROWE, A. et al. Haemonchus contortus Infection in Sheep: Parasite Fecundity Correlates with Worm Size and Host Lymphocyte Counts. Vet. Parasitol., [s. 1.], v.153, p.285-93, 2008.

SANYAL, P .K.; MARU, A.; GUPTA, A. K. The Use of Injectible Rafoxanide Against Natural Ovine Nasal Myiasis. Vet. Parasitol., [s. 1.], v.19, p.127-31, 1986.

SCALA, A. et al. Sheep Oestrosis (Oestrus ovis Linné 1761, Diptera: Oestridae) in Sardinia, Italy. Vet. Parasitol., [s. 1.], v.102, p.133-41, 2001.

SCHENKEL, D. M. et al. Surto de Oestrus ovis em ovinos em Mato Grosso. Pesq. Agropec. Bras., [s. 1.], v.32, p.754-6, 2012.

SHOORIJEH, S. et al. Prevalence and Intensity of Oestrus ovis in Sheep of Shiraz, Southern Iran. Trop. Anim. Health Prod., [s. 1.], v.41, p.1259-62, 2009.

SILVA, B. F. 2012. Epidemiologia das infestações por Oestrus ovis em ovinos criados em Botucatu e influência da raça ovina no parasitismo. Botucatu, 2012. Tese (doutorado) - Universidade Estadual Paulista. ; BASSETTO, C. C.; AMARANTE, A. F. T. Epidemiology of Oestrus ovis (Diptera: Oestridae) in Sheep in Botucatu, State of São Paulo. Rev. Bras. Parasitol. Vet., [s. 1.], v.21, p.386-90, 2012a. Immune Responses in Sheep Naturally Infected with Oestrus ovis (Diptera: Oestridae) and Gastrointestinal Nematodes. Vet. Parasitol., [s. 1.], v.190, p.120-6, 2012b. et al. Parasitism by Oestrus ovis: Influence of Sheep Breed and Nematode Infections. Vet. Parasitol., [s. 1.], v.186, p.437-44, 2012c. et al. Prevalence of Oestrus ovis (Diptera: Oestridae) in Sheep from the São Paulo Central Region. Brazil. Rev. Bras. Parasitol. Vet., [s. 1.], v.22, p.18-21, 2013.

TABOURET, G. et al. Serine Protease Activity in Excretory-Secretory Products of Oestrus ovis (Diptera: Oestridae) Larvae. Vet. Parasitol., [s. 1.], v.114, p.305-14, 2003a. 
et al. Cellular and Humoral Local Immune Responses in Sheep Experimentally Infected with Oestrus ovis (Diptera: Oestridae). Vet. Res., [s. 1.], v.34, p.231-41, 2003b.

TEREFE, G. et al. Haemonchus contortus Egg Excretion and Female Length Reduction in Sheep Previously Infected with Oestrus ovis (Diptera: Oestridae) Larvae. Vet. Parasitol., [s. 1.], v.128, p.271-83, 2005.

USLU, U.; DIK, B. Prevalence and Intensity of Oestrus ovis in Akkaraman Sheep in the Konya Region of Turkey. Med. Vet. Entomol., [s. 1.], v.20, p.347-9, 2006.

YACOB, H. T. et al. Experimental Concurrent Infection of Sheep with Oestrus ovis and Trichostrongylus colubriformis: Negative Interactions between Parasite Populations and Related Changes in the Cellular Responses of Nasal and Digestive Mucosae. Vet. Parasitol., [s. 1.], v.104, p.307-17, 2002.

et al. Concurrent Parasitic Infections of Sheep: Depression of Trichostrongylus colubriformis Populations by a Subsequent Infection with Oestrus ovis. Vet. Parasitol., [s. 1.], v.121, p.297-306, 2004.

et al. Experimental Concurrent Infection of Sheep with Oestrus ovis and Trichostrongylus colubriformis: Effects of Antiparasitic Treatments on Interactions between Parasite Populations and Blood Eosinophilic Responses. Vet. Parasitol., [s. 1.], v.137, p.184-8, 2006.

YILMA, J. M.; DORCHIES, P. Epidemiology of Oestrus ovis in Southwest France. Vet. Parasitol., [s. 1.], v.40, p.315-23, 1991.

; GENET, A. Epidemiology if the Sheep Nasal Bot, Oestrus ovis (Diptera: Oestridae), in Central Ethiopia. Rev. Med. Vet., [s. 1.], v.151, p.143-50, 2000.

ZUMPT, P. Myiasis in Man and Animals in the Old World. London: Butterworths, 1965, 257p. 


\section{0 \\ PiolHos e ÁCAROS}

\section{Piolhos}

\section{Introdução}

Os piolhos são insetos pequenos, com $0,4 \mathrm{~mm}$ a $10 \mathrm{~mm}$ de comprimento quando adultos, ápteros (sem asas) e com o corpo achatado dorsoventralmente. Pertencem à ordem Phthiraptera e são classificados em dois grandes grupos: (1) Anoplura (piolhos sugadores - hematófagos), com duas espécies que ocorrem em ovinos, Linognathus ovillus e Linognathus pedalis; e (2) Mallophaga (piolhos mastigadores), com a espécie Bovicola (= Damalinia) ovis. Os piolhos dos ruminantes apresentam elevada especificidade parasitária, e, usualmente, cada espécie apresenta preferência por determinada área do corpo do animal. Por exemplo, L. ovillus tem preferência pela face e pelo corpo; L. pedalis, pelas patas, abdome ventral e escroto; enquanto B. ovis ocorre na região superior do corpo do animal (Cortinas; Jones, 2006).

Bovicola ovis (Figura 78) é a principal espécie causadora de pediculose em ovinos no Brasil. Em assentamentos de reforma agrária do município de Mossoró (RN), 74,5\% dos ovinos examinados estavam parasitados (Bezerra et al., 2010). 
Figura 78 - Bovicola ovis é a principal espécie de piolho em ovinos criados no Brasil

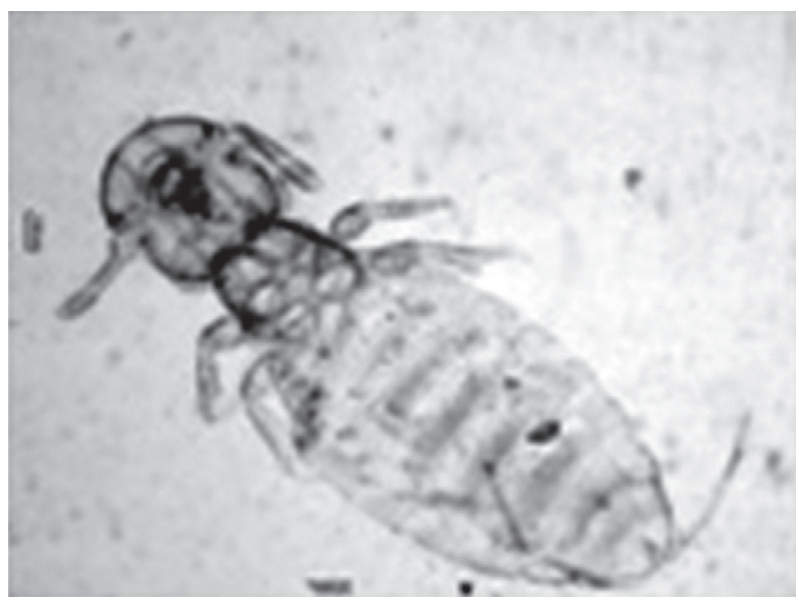

\section{Ciclo evolutivo}

Os piolhos apresentam desenvolvimento hemimetabólico, e seu ciclo de vida inclui os seguintes estádios: ovos, três ínstares de ninfa, sendo que o último deles, após muda, dá origem ao adulto. Embora com ampla variação entre espécies, o estádio de ovo usualmente dura de quatro dias a quinze dias, e cada ínstar de ninfa, de três dias a oito dias; os adultos vivem por até 35 dias. Uma fêmea de piolho fertilizada pode produzir em média até dez ovos por dia. A fêmea põe os ovos, conhecidos como lêndeas, próximos à superfície da pele, fixados aos pelos ou à lã por uma substância cimentante. Os requerimentos em relação à temperatura ótima para o desenvolvimento do embrião dentro do ovo são elevados, e as variações de temperatura devem ser mínimas. Por essa razão, a postura dos ovos é realizada em uma determinada área do corpo que atenda aos requerimentos de temperatura (Durden, 2002).

Em condições ótimas, os piolhos podem completar de dez a doze gerações por ano, porém, isso raramente ocorre na natureza. São vários os fatores que podem causar redução na população ou 
no número de gerações de piolhos, dentre os quais se destacam os seguintes: o ato de os animais lamberem-se ou coçarem-se, a resistência imunológica, troca de pelagem e alterações hormonais. Além desses, são também citados predadores (especialmente aves insetívoras em ungulados de grande porte), parasitas e parasitoides. Condições climáticas desfavoráveis podem também causar redução no número de gerações de piolho (ibidem).

Os piolhos, em todos seus estádios, obtêm nutrientes necessários para sua existência no próprio hospedeiro, onde passam toda a vida. A maioria desses insetos sobrevive apenas poucas horas fora da superfície corporal, e por essa razão a transmissão ocorre usualmente por contato físico entre os hospedeiros.

\section{Patogenia e sinais clínicos}

Bovicola ovis é um ectoparasita obrigatório, e todo seu ciclo de vida ocorre sobre a pele e na lã dos ovinos (Pfeffer et al., 2010). Os parasitas alimentam-se na superfície da pele, onde ingerem lipídeos, descamações e bactérias. Existem registros de variação sazonal no número de piolhos, com aumento no inverno e na primavera e redução no verão. Esse padrão tem sido atribuído aos efeitos da tosquia, a temperaturas elevadas do verão, à radiação solar e a chuvas pesadas. Embora os fatores ambientais sejam indiscutivelmente importantes nas variações sazonais, outros fatores também podem estar envolvidos. Apesar de hábito alimentar não invasivo, B. ovis estimula resposta imunológica, a qual tem impacto sobre a população de piolho no hospedeiro. Alguns ovinos não se tornam infestados ou não apresentam infestação pesada mesmo quando desafiados repetidamente, o que reforça as evidências de que a resposta imunológica desempenha papel na regulação da população de piolhos (James, 1999).

Substâncias produzidas por B. ovis sensibilizam imunologicamente os ovinos. As fezes dos piolhos, que se acumulam sobre o animal, contêm antígenos e alergênicos. $\mathrm{O}$ alergênico denominado 
“Bov o 1", presente nas fezes dos piolhos, é provavelmente o principal e desempenha papel importante na sensibilização e na promoção de alterações na pele de animais infestados (Pfeffer et al., 2010).

Aparentemente, B. ovis causa poucos problemas em ovinos deslanados, em comparação com ovinos lanados. Na África do Sul, observou-se que, em ovinos deslanados da raça Dorper, a infestação por piolho tem pouco ou nenhum efeito na produtividade, não havendo registros de infestações pesadas nessa raça (Fourie; Horak, 2000).

\section{Profilaxia}

Bovicola ovis completa todo seu ciclo sobre o corpo do hospedeiro; não possui fase de vida livre. No geral, os parasitas sobrevivem pouco tempo fora do corpo dos animais, e o principal mecanismo de transmissão é o contato entre os hospedeiros. Devido a esse aspecto da biologia dos parasitas, é possível erradicá-los de uma criação com relativa facilidade.

Em alguns casos, os piolhos podem sobreviver por período relativamente longo fora do corpo do hospedeiro, especialmente quando estão localizados em locais com presença de suarda, substância gordurosa presente na lã dos ovinos. Usualmente, os calçados dos tosquiadores não são lavados e contêm teor elevado de suarda e reentrâncias, onde os insetos alojam-se e podem sobreviver. Os calçados podem abrigar adultos e ninfas capazes de sobreviver por até dez dias. Portanto, por meio dos calçados dos trabalhadores, existe o risco de introdução de $B$. ovis em criações livres de parasitas (Crawford et al., 2001).

A profilaxia da pediculose é realizada com a aplicação de inseticidas à base de organofosforados, piretroides ou amitraz em banhos de imersão, que devem ser aplicados em todos os animais do rebanho simultaneamente. Recomenda-se que os animais sejam banhados de dez a quinze dias após a tosquia, repetindo-se o banho doze dias após a primeira aplicação. 


\section{Ácaros}

Didaticamente, os ácaros são classificados em dois grupos: um constituído de parasitas que atingem grande porte na fase adulta, os carrapatos, e outro constituído de parasitas microscópicos, os ácaros causadores de sarna.

\section{Carrapatos}

Considerando-se a população mundial de ovinos, aproximadamente 97 espécies de carrapatos pertencentes a dez gêneros foram registradas nesses hospedeiros. As principais alterações causadas pelos carrapatos devem-se à transmissão de patógenos, à inoculação de toxinas e aos danos diretos, que incluem lesões na pele e anemia, devido à espoliação sanguínea. Porém, o impacto das infestações por carrapato na produtividade dos ovinos é muito pouco estudado e tem recebido pouca atenção da comunidade científica (Fourie; Horak, 2000).

Os ovinos podem ser parasitados por Rhipicephalus microplus e por Amblyomma cajennense (Figura 79), especialmente quando compartilham pastagens com bovinos e equinos parasitados por esses carrapatos. Em inquérito realizado com ovinocultores do estado de São Paulo, 31,3\% relataram a presença de carrapatos em seus rebanhos (Madeira et al., 2000). Em assentamentos de reforma agrária do município de Mossoró (RN), de 232 ovinos examinados, 0,86\% estavam parasitados por Rhipicephalus microplus, e 0,43\%, por Amblyomma parvum (Bezerra et al., 2010). Em oito propriedades localizadas no estado do Maranhão, 20 dos 170 ovinos examinados estavam parasitados por $R$. microplus (Brito et al., 2005).

Aparentemente, as infestações por carrapato não costumam constituir problema severo nas criações brasileiras de ovinos. Porém, as lesões produzidas na pele dos animais pelo aparelho bucal dos carrapatos podem predispor a instalação de miíases causadas por Cochliomyia hominivorax. 
Figura 79 - Amblyomma cajennense próximo do olho e na pata de um ovino
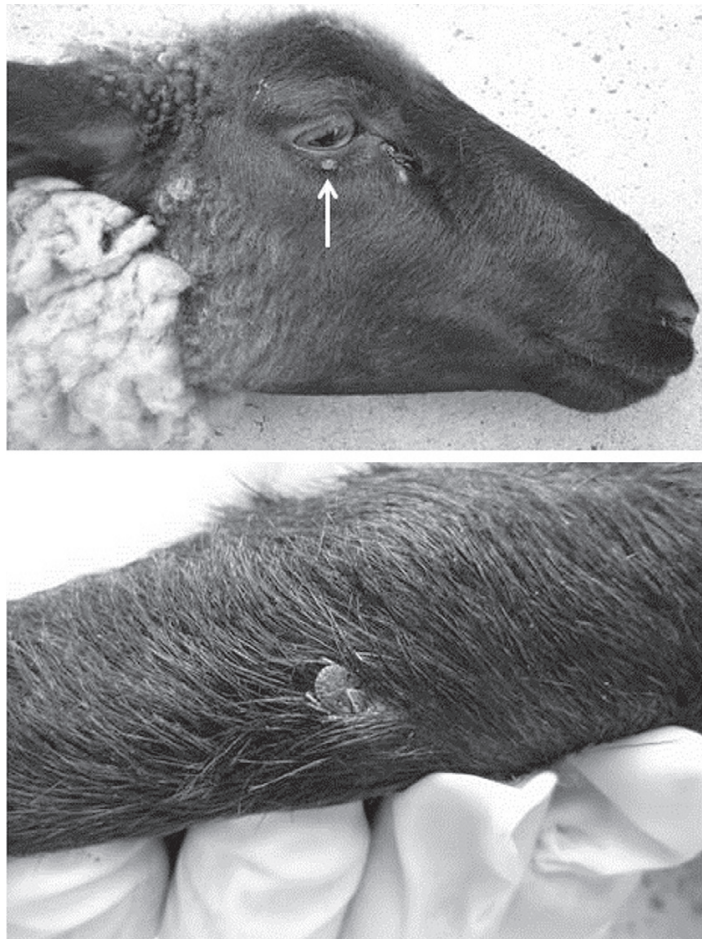

\section{Ácaros causadores de sarna}

Várias espécies de ácaros podem ocorrer em ovinos, tais como Sarcoptes scabiei var. ovis e Psoroptes ovis. Porém, o principal agente causador da sarna ovina é a espécie P. ovis (Acari: Psoroptidae). A sarna ovina pode ser definida como uma dermatite superficial exsudativa de caráter alérgico e crônico resultante da infestação por $P$. ovis. A enfermidade é altamente contagiosa e é de notificação obrigatória no Brasil. Sem tratamento, a enfermidade evolui ao longo de semanas ou meses, e as lesões podem acometer a maioria da superfície da pele. Ovinos exibem prurido intenso e redução no ganho em peso. 


\section{Biologia e transmissão}

Psoroptes ovis é ectoparasita obrigatório de ovinos, caprinos e bovinos. Apresenta cinco estádios em seu ciclo de vida: ovo; larva (com três pares de patas), dois estádios de ninfa (protoninfa e tritoninfa) e finalmente machos e fêmeas adultos. As ninfas e os adultos apresentam quatro pares de patas (Sanders et al., 2000).

Os parasitas completam todo o ciclo de vida sobre a superfície da pele do hospedeiro em 10 a 14 dias, e a transmissão se dá por contato. Apesar de constituir uma única espécie parasita de ruminantes, a transmissão natural entre hospedeiros de diferentes espécies raramente é registrada em condições de campo. Os raros casos aparentemente não têm importância epidemiológica. No Reino Unido, por exemplo, a sarna psoróptica em ovinos é endêmica, porém rara em bovinos; em contraste, na Bélgica, a sarna psoróptica é extremamente comum em bovinos, mas raramente é observada em ovinos (Losson, 2012).

Embora seja parasita obrigatório, $P$. ovis pode sobreviver fora do corpo do hospedeiro por período significativo de tempo, e os ácaros presentes no ambiente podem reinfestar ou infestar novos animais. Em condições controladas de umidade (95\%) em laboratório, $P$. ovis sobreviveu por aproximadamente quinze dias quando mantido em temperatura de $9^{\circ} \mathrm{C}$ e por cinco dias em temperatura de $30^{\circ} \mathrm{C}$ (Smith et al., 1999).

\section{Patogenia e sinais clínicos}

Embora P. ovis, com suas peças bucais, possa causar abrasão no estrato córneo da pele, não existem evidências de penetração de tais peças além das camadas superficiais de queratina que formam o estrato córneo. Vários membros da ordem Astigmata caracterizam-se por ingerirem alimento sólido, entretanto, Psoroptes é adaptado para ingerir alimento líquido, que consiste principalmente de exsudato seroso oriundo do hospedeiro. Conforme os ácaros deslocam-se sobre a superfície corporal, material antigênico, alergênico e enzimaticamente ativo é depositado, causando respos- 
ta inflamatória na pele, que resulta em lesões com a liberação de exsudato seroso e eritrócitos, material utilizado pelos ácaros em sua alimentação (Hamilton et al., 2003). Portanto, essa resposta imunoinflamatória desencadeada pelos produtos dos ácaros é a principal causa de prurido e alterações patológicas. A dermatite apresenta características de reação imediata de hipersensibilidade e é provavelmente desencadeada por vários alérgenos, inclusive proteinases, que provavelmente têm papel importante para iniciar a lesão e degradam várias proteínas sanguíneas, propriedade que pode auxiliar na alimentação do ácaro. As proteinases também degradam as imunoglobulinas, possivelmente auxiliando na imunoevasão (Kenyon; Knox, 2002). As fezes de Psoroptes contêm guanina (2-aminohypoxanthine), um composto que causa irritação nos olhos e na pele, além de ampla gama de alérgenos, tais como cisteina e aspartyl proteinases. Componentes da saliva podem também iniciar ou exacerbar a resposta inflamatória e o extravazamento de exsudato seroso. As alterações patológicas podem ser exacerbadas pela presença de bactérias que se desenvolvem nas lesões, e a natureza da sarna pode ser determinada em parte pelas espécies de bactérias presentes (Hamilton et al., 2003).

O hospedeiro apresenta prurido intenso, dermatite extensa, hiperqueratose e infecção bacteriana secundária. Porém, após o estabelecimento da infestação, ocorre redução significativa no crescimento da lesão, sugerindo que os produtos dos ácaros podem induzir imunidade protetora contra P. ovis. Produtos secretórios e excretórios induzem a produção de IgE específica contra $P$. ovis, indicando que os ácaros induzem reação de hipersensibilidade do Tipo I em ovinos. O mecanismo envolvido na proteção desencadeada pela imunidade via hipersensibilidade permanece desconhecido (ibidem).

\section{Ocorrência de sarna ovina no Brasil}

A sarna ovina teve seu controle e combate iniciados em 1942, pela Secretaria da Agricultura do Estado do Rio Grande do Sul. 
O estado manteve-se livre da sarna ovina por aproximadamente vinte anos. No entanto, em 1976, ocorreu um surto de sarna no município de Uruguaiana, mudando o cenário do estado. De 1980 a 1987, essa parasitose foi diagnosticada em 55 municípios do estado, totalizando 1.673 focos (Barboza; Dutra, 1989). A partir daí houve redução no número de casos registrados, chegando perto da erradicação nos últimos dez anos. Entretanto, nos dois últimos anos os focos de sarna vêm novamente aumentando na região da fronteira com o Uruguai. Em 2011, houve dez focos registrados, e em 2012, sete. Todos esses focos foram controlados pelo SVO (Serviço Veterinário Oficial) do estado, contudo, observa-se que alguns focos estão reaparecendo em propriedades já tratadas, e outros têm surgido em locais onde não havia casos. No início de 2013 houve aumento na incidência de sarna em Livramento, com notificação de dezesseis propriedades, onde eram criados aproximadamente nove mil animais (Tomazzeti, 2013).

\section{Profilaxia}

Psoroptes ovis completa seu ciclo no hospedeiro; não possui fase de vida livre. Como geralmente os parasitas sobrevivem pouco tempo fora do corpo dos animais, o principal mecanismo de transmissão é o contato entre os hospedeiros. Devido a esse aspecto da biologia dos parasitas, é possível erradicá-los de uma criação com relativa facilidade.

A exemplo das infestações por piolho, a profilaxia da sarna pode ser realizada com a aplicação de produtos acaricidas (organofosforados, piretroides ou amitraz) em banhos de imersão, a que todos os animais do rebanho devem ser submetidos. Recomenda-se que os animais sejam banhados de dez a quinze dias após a tosquia, repetindo-se o banho doze dias após a primeira aplicação.

Além de banhos com produtos acaricidas, pode-se utilizar tratamento sistêmico com lactonas macrocíclicas. Duas aplicações de ivermectina $(200 \mu \mathrm{g} / \mathrm{kg}$, via subcutânea), administradas com sete dias de intervalo, mostraram-se altamente eficazes contra $P$. ovis 
em rebanhos ovinos (Soll et al., 1992). O mesmo ocorreu após a aplicação de duas doses de moxidectina $(200 \mu \mathrm{g} / \mathrm{kg})$, com intervalo de dez dias (Fthenakis et al., 2000).

\section{Referências bibliográficas}

BARBOSA, F. F.; DUTRA, M. G. B. Análise e comportamento da sarna e piolheira ovina no estado do RS, período de 1980 a 1987. In: Curso de Parasitologia Animal, 2, Bagé, 1988, Anais... Bagé (RS). CBPV. p.45-59, 1989.

BEZERRA, A. D. S. et al. Ectoparasitos em caprinos e ovinos no município de Mossoró, Rio Grande do Norte. Ci. Anim. Bras., [s. 1.], v.11, p.110-6, 2010.

BRITO, D. R. B.; SANTOS, A. C. G.; GUERRA, R. M. S. N. C. Ectoparasitos em rebanhos de caprinos e ovinos na microrregião do Alto Mearim e Grajaú, Estado do Maranhão. Rev. Bras. Parasitol. Vet., [s. 1.], v.14, p.59-63, 2005.

CORTINAS, R.; JONES, C. J. Ectoparasites of Cattle and Small Ruminants. Vet. Clin. N. Am.-Food A., [s. 1.], v.22, p.673-93, 2006.

CRAWFORD, S.; JAMES, P. J.; MADDOCKS, S. Survival Away from Sheep and Alternative Methods of Transmission of Sheep Lice (Bovicola ovis). Vet. Parasitol., [s. 1.], v.94, p.205-16, 2001.

DURDEN, L. A. Lice (Phthiraptera). Medical and Veterinary Entomology, San Diego (CA), 2002, p.45-65.

FOURIE, L. J.; HORAK, I. G. Status of Dorper Sheep as Hosts of Ectoparasites. Small Rumin. Res., [s. 1.], v.36, p.159-64, 2000.

FTHENAKIS, G. C. et al. Efficacy of Moxidectin Against Sarcoptic Mange and Effects on Milk Yield of Ewes and Growth of Lambs. Vet Parasitol., [s. 1.], v.87, p.207-16, 2000.

HAMILTON, K. A. et al. A Physiological and Biochemical Model for Digestion in the Ectoparasitic Mite. Psoroptes ovis (Acari: Psoroptidae). Int. J. Parasitol., [s. 1.], v.33, p.773-85, 2003.

JAMES, P. J. Do Sheep Regulate the Size of their Mallophagan Louse Populations? Int. J. Parasitol., [s. 1.], v.29, p.869-75, 1999.

KENYON, F.; KNOX, D. The Proteinases of Psoroptes ovis, the Sheep Scab Mite - their Diversity and Substrate Specificity. Vet. Parasitol., [s. 1.], v.105, p.317-25, 2002. 
LOSSON, B. J. Sheep Psoroptic Mange: An Update. Vet. Parasitol., [s. 1.], v.189, p.39-43, 2012.

MADEIRA, N. G.; AMARANTE, A. F. T.; PADOVANI, C. R. Diversity of Ectoparasites in Sheep Flocks in São Paulo, Brazil. Trop. Anim. Health Prod., [s. 1.], v. 32, p. 225-32, 2000.

PFEFFER, A. et al. Identification of an Abundant Allergen from the Sheep Louse, Bovicola ovis. Int. J. Parasitol., [s. 1.], v.40, p. 911-9, 2010.

SANDERS, A. et al. Life-Cycle Stage Morphology of Psoroptes Mange Mites. Med. Vet. Entomol., [s. 1.], v.14, p.131-1, 2000.

SMITH, K. E. et al. The Effects of Temperature and Humidity on the Off-Host Survival of Psoroptes ovis and Psoroptes cuniculi. Vet. Parasitol., [s. 1.], v.83, p.265-75, 1999.

SOLL, M. D. et al. Treatment and Control of Sheep Scab (Psoroptes ovis) with Ivermectin Under Field Conditions in South Africa. Vet. Rec., [s. 1.], v.130, p. 572-4, 1992.

TOMAZZETI, N. Secretaria da Agricultura faz mutirão para controle da sarna ovina na fronteira. Disponível em: <http://www.estado.rs.gov. br/noticias/1/109938/>. Acesso em: 14 mar. 2013. 
SOBRE O LIVRO

Formato: $14 \times 21 \mathrm{~cm}$

Mancha: $23,7 \times 42,5$ paicas

Tipologia: Horley Old Style 10,5/14

Papel: Off-set $75 \mathrm{~g} / \mathrm{m}^{2}$ (miolo)

Cartão Supremo $250 \mathrm{~g} / \mathrm{m}^{2}$ (capa)

1ạ edição: 2014

EQUIPE DE REALIZAÇÃO

Coordenação Geral

Marcos Keith Takahashi 